Maíra Beauchamp Salomi

\title{
O ACORDO DE LENIÊNCIA E SEUS REFLEXOS PENAIS
}

Dissertação de Mestrado

Orientador: Professor-Doutor Eduardo Reale Ferrari

Faculdade de Direito da Universidade de São Paulo

São Paulo 


\section{Maíra Beauchamp Salomi}

\section{O ACORDO DE LENIÊNCIA E SEUS REFLEXOS PENAIS}

Dissertação de Mestrado apresentada ao Departamento de Direito Penal da Faculdade de Direito da Universidade de São Paulo, como requisito parcial para a obtenção do título de Mestre, sob a orientação do Professor-Doutor Eduardo Reale Ferrari.

São Paulo 
À minha querida tia Jane, presença eterna em minha vida. 


\section{AGRADECIMENTOS}

Aos ilustres Professores do Curso de Pós-Graduação da Faculdade de Direito do Largo São Francisco, pelos inestimáveis ensinamentos.

Ao Professor Eduardo Reale Ferrari, pela oportunidade concedida e pela influência em minha formação acadêmica desde os primeiros anos do Curso de graduação em Direito.

À minha mãe, pelos nobres valores transmitidos e por toda a minha educação.

Ao meu pai, pelo carinho, incentivo e apoio constantes, sem os quais nada disso seria possível.

Ao meu querido marido Flávio, pelo amor, compreensão, paciência e, principalmente, por acreditar em mim. 


\section{RESUMO}

Com as mudanças do mundo moderno surgiu uma justificada preocupação global com a crescente prática de delitos contra a ordem econômica e a dificuldade que as autoridades enfrentam para apurá-los. Para socorrê-las surge o acordo de leniência, instrumento de investigação altamente eficaz de ampla aplicação em nações estrangeiras. Mas não por isso, este instituto deve ser importado ao nosso ordenamento tal qual utilizado em terras alienígenas, ignorando-se os direitos do delator e em flagrante desrespeito aos princípios constitucionais. Diante dessa problemática, o presente trabalho tem por objetivo realizar uma análise crítica acerca deste acordo e dos reflexos que provoca no âmbito penal, a fim de serem detectadas as falhas e incongruências de seu procedimento, bem como os seus aspectos inconstitucionais e, com isso, contribuir para a sua adequação ao ordenamento jurídico e seu desenvolvimento como meio de investigação para o combate aos crimes contra a ordem econômica, sobretudo, a formação de cartel. Em vista disso, será feito um estudo inicial sobre a relação entre Direito e Economia, Direito Concorrencial, seus interesses e a necessidade de tutela, inclusive pela via penal, da concorrência pelo Estado. Posteriormente, passar-se-á à análise das condutas anticoncorrenciais e dos crimes contra a ordem econômica, constatando-se os empecilhos para a investigação de tais delitos. A partir deste exame, far-se-á uma apresentação do acordo de leniência, suas origens, sua regulamentação em outros países para, então, a par das preocupações éticas que o circundam, realizar uma apreciação crítica dos efeitos que provoca na esfera penal. Ao final, em concordância com a necessidade de se manter o instituto, o presente trabalho buscará sanar as deficiências da atual legislação sobre o tema - e, inclusive, da recémaprovada Lei $\mathrm{n}^{\mathrm{o}} 12.529 / 2011$-, propondo alterações que visam minimizar a discricionariedade, o subjetivismo e a insegurança jurídica que permeiam o acordo, de modo a adequá-lo aos ditames constitucionais e torná-lo mais atraente aos candidatos.

Palavras-chave: Direito Penal Econômico. Direito Concorrencial. Cartel. Acordo de leniência. Delação premiada. Extinção da punibilidade. 


\section{ABSTRACT}

The modern world has undergone changes that justify the global concern with the increasing occurrence of criminal offenses against the economic order and with the difficulty the authorities face to ascertain them by investigation. Precisely to aid the authorities, looms the leniency agreement, a highly effective investigation instrument of broad use in foreign countries. In spite of that, this institute shall not be imported to our legal system as regularly applied abroad ignoring the rights of the delator and of flagrant disrespect to constitutional principles. Before this issue, the current paper has the objective to promote a critical analysis concerning the leniency agreement and the reflexes it triggers in the criminal field, in order to evidence the flaws and incompatibility of its procedure, as well as its unconstitutional aspects, by that, be able to contribute with its suitability to the criminal systemand to its development as a mean of investigation to fight crimes against the economic order, overall, the formation of cartel. Due to that, an initial study is proposed about the relation between Law and Economics, Competition Law, their interests and the need of tutelage containing the criminal manner and the competition by the State. Later, an analysis of anti-competitive conducts and of crimes against the economic order containing the impediments to the investigation of such criminal offenses. Resulting from this examination, there will be a presentation of the leniency agreement, its origins, regulations in other countries, so that, in addition to the ethical concerns that surround the agreement, be possible the fulfillment of critical appraisal to the effects it causes in the criminal field. Finally, in accordance to the need to support the institute, the current paper seeks to heal the gaps of the current legislation related to the theme - including, the newly approved Law number 12.529/2011 - proposing changes that aim at minimizing the discretion, subjectivism and juridical insecurity that permeates the agreement, in a way to adequate it to the constitutional precepts and make it become more engaging to the candidates.

Keywords: Economic Criminal Order. Competition Law. Cartel. Leniency agreement. Plea bargain. Extinction of punishment. 
1.1 Conceitos Básicos para a Economia: as Necessidades Humanas e a Lei da Escassez

016

1.2 Liberalismo Econômico 018

$\begin{array}{lll}1.3 & \text { Falhas do Mercado } & 022\end{array}$

1.3.1 Mobilidade dos fatores de produção $\quad 023$

1.3.2 Acesso às informações relevantes 023

1.3.3 Concentração econômica 025

1.3.4 Externalidades $\quad 026$

1.3.5 Bens coletivos $\quad 028$

1.3.6 Custos de transação $\quad 029$

1.4 Direito Econômico 030

$\begin{array}{lll}1.5 & \text { Ordem Econômica } & 034\end{array}$

$\begin{array}{ll}\text { 1.5.1 Constituições econômicas } & 036\end{array}$

$\begin{array}{lll}1.6 & \text { Livre Concorrência } & 041\end{array}$

CAPÍtUlO 2 A CONCORRÊNCIA

$\begin{array}{lll}2.1 & \text { Direito Concorrencial } & 044\end{array}$

2.1.1 Breve escorço histórico do direito concorrencial 046

2.1.2 Direito concorrencial brasileiro 051 
2.2.1 Interesse da ordem concorrencial $\quad 056$

$\begin{array}{lll}\text { 2.2.2 } & \text { Interesse dos consumidores } & 057\end{array}$

$\begin{array}{lll}\text { 2.2.3 Interesse dos concorrentes } & 059\end{array}$

2.3 Direito Penal Moderno: o Direito Penal Econômico 061

2.3.1 Instituto do bem jurídico penal 066

$\begin{array}{ll}\text { 2.3.2 Bem jurídico penal supraindividual } & 068\end{array}$

2.3.3 Fundamentos da tutela penal da concorrência: a concorrência como bem jurídico penal supraindividual $\quad 070$

\section{CAPÍTULO 3 AS CONDUTAS ANTICONCORRENCIAIS 082}

3.1 Contexto para Identificação das Condutas Anticoncorrenciais 082

$\begin{array}{lll}3.2 & \text { Estrutura do Ilícito Concorrencial } & 088\end{array}$

$\begin{array}{lll}\text { 3.3 Acordos entre Agentes Econômicos: Colusão } & 094\end{array}$

$\begin{array}{ll}\text { 3.3.1 Colusão vertical } & 095\end{array}$

$\begin{array}{ll}\text { 3.3.2 Colusão horizontal: os cartéis } & 101\end{array}$

3.3.2.1 Espécies de acordos $\quad 106$

3.3.2.1.1 Acordos Expressos 107

3.3.2.1.2 Acordos Tácitos 111

$\begin{array}{llr}\text { 3.4 Tutela Penal da Concorrência } & 113\end{array}$

3.4.1 Histórico brasileiro de repressão penal às práticas $\begin{array}{ll}\text { anticoncorrenciais } & 114\end{array}$

3.4.2 Lei $n^{\circ}$ 8.137/90: os crimes contra a ordem econômica 118 
4.1.1 Requisitos para a sua celebração

4.1.3.3 França 158

4.1.3.4 Grécia 161

4.1.3.5 Canadá 164

4.1.3.6 Austrália 170

4.2.2.3 Decisão do Conselho Administrativo de Defesa Econômica e a reserva de jurisdição

4.2.2.4 Provas produzidas em acordo de leniência sem êxito

4.2.2.5 Acordo de leniência e prática de crimes não previstos na Lei $n^{\circ} 8.137 / 90$ 
4.2.3 Mecanismos de solução alternativa de procedimento administrativo: acordo de leniência e termo de compromisso de cessação de prática

4.3 Propostas Legislativas e a Recém-Aprovada Lei $n^{0}$ 12.529, de 30 de Novembro de 2011

CONCLUSÃO 268

REFERÊNCIAS 


\section{INTRODUÇÃO}

Atualmente, mesmo nos modelos econômicos mais liberais, nota-se uma intensa preocupação com as infrações contra a ordem econômica e a criação de uma sistemática normativa para coibi-las. Isto porque, por certo, a eficiência econômica deve reger-se em uma ordem econômica juridicamente determinada, na qual o Estado regulamente a concorrência existente no mercado.

Dentre essas infrações, o cartel - que, em linhas gerais, traduz um acordo ou prática concertada entre concorrentes - revela-se a mais grave, pelo fato de provocar, ao mesmo tempo, eliminação da concorrência, impossibilidade de escolha pelos consumidores, elevação de preços dos produtos e serviços e, reflexamente, desinteresse por parte da indústria em avanços tecnológicos e inovações, impedindo a melhoria das condições do mercado. Por tais motivos, em quase todas as nações, esta conduta passou a ser a mais preocupante nos dias de hoje.

Ao seguir esta tendência mundial, nosso ordenamento jurídico passou a prever regras administrativas, ${ }^{1}$ civis $^{2}$ e penais ${ }^{3}$ que visassem o desestímulo e a repressão da prática infracional desestabilizadora do principal fundamento do sistema capitalista: a livre concorrência.

Todavia, não obstante a indiscutível abrangência, inteligibilidade e atualidade das normas referidas, as condutas atentatórias à ordem econômica continuam a exigir árdua tarefa para que se obtenha prova de sua consumação, desafiando diretamente os órgãos reguladores que objetivam defender a livre concorrência.

Conforme já assentado pelo próprio Conselho Administrativo de Defesa Econômica (CADE), o simples paralelismo de preços entre concorrentes de mercado não basta para a caracterização do crime de cartel.

\footnotetext{
${ }^{1}$ Lei $n^{\circ} 8.884 / 94$.

${ }^{2}$ Normas que suportam as ações indenizatórias de consumidores em face de condutas cartelizadoras.

${ }^{3}$ Tem-se como exemplo as Leis $n^{\circ}$ s $8.137 / 90$ e 8.666/93.
} 
Até porque, ao contrário do que ocorria à época de ADAM SMITH, em que o conluio criminoso, como ele mesmo ilustrou, ${ }^{4}$ era celebrado em encontros pessoais, hodiernamente os autores da empreitada criminosa utilizam-se de meios modernos, tais como correspondências eletrônicas, conversas telefônicas e conversas telemáticas em tempo real.

Se, de um lado, essas comodidades modernas auxiliam a traçar as evidências, registrando o rastro criminoso e revelando todo o modus operandi e a autoria dos delitos, por outro, encurta as distâncias e torna mais ágil e eficaz a comunicação entre os criminosos.

Afora isso, a ilegalidade e clandestinidade que revestem a formação e atuação dos cartéis tornam a sua investigação e a comprovação de sua prática ainda mais complexas, exigindo dos órgãos estatais instrumentos de averiguação cada vez mais eficientes.

Diante desse quadro, o Sistema Brasileiro de Defesa da Concorrência (SBDC) e os órgãos investigativos do Poder Público passaram a utilizar uma série de recursos, a fím de reprimir a constante prática de cartel, tais como a busca e apreensão, a interceptação telefônica, ambiental e telemática.

Ocorre que estes recursos não se mostraram aptos a diminuir, em números expressivos, as infrações, quer administrativas, quer penais, contra a ordem econômica. Assim sendo, foi criado, no ano de 2000, o acordo de leniência, modalidade de delação premiada inserida em nossa legislação através da Lei nº 10.149/2000.

A ineficácia dos instrumentos de combate às condutas anticoncorrenciais levou as autoridades antitruste a enxergarem no acordo de leniência um caminho para a ampliação de seus poderes de investigação, de maneira que este instituto passou a ser considerado o “[...] pilar fundamental da Política Nacional de Proteção da Ordem Econômica.,5

Embora se assemelhe com o instituto da delação premiada, o acordo de "lenidade" produz efeitos inéditos. Na esfera administrativa, os efeitos estendem-se desde uma redução de pena aplicada de um a dois terços até a extinção da ação punitiva da

\footnotetext{
4 “É raro pessoas que exercem a mesma atividade se encontrarem reunidas, seja para festejar ou se distrair, sem que a conversa termine em alguma conspiração contra o público, ou em algum conluio para elevar os preços. É impossível, na verdade, impedir tais encontros por uma lei que pudesse ser executada e ao mesmo tempo fosse compatível com a liberdade e a justiça.” (SMITH, Adam. A riqueza das nações. P. 165).

${ }^{5}$ Artigo 61, caput, da Portaria $\mathrm{n}^{\circ}$ 4, de 05 de janeiro de 2006.
} 
administração pública. Por outro lado, no âmbito penal, especificamente no que tange aos crimes contra a ordem econômica, a celebração do acordo de leniência " [...] determina a suspensão do curso do prazo prescricional e impede o oferecimento da denúncia." 6

É inegável, portanto, que este instituto aumenta as chances de se descobrir e punir um cartel, além de gerar instabilidade e suscitar desconfiança entre os seus membros, o que, de fato, enuncia a eficácia do programa. Conquanto recente o instituto, e por isso ainda não emoldurado por completo em nosso sistema jurídico, sua aplicação está ascendendo rapidamente.

Contudo, o impacto que o acordo de leniência tem gerado na esfera penal não vem sendo muito aplaudido, tendo em vista a insegurança jurídica que a celebração do acordo traz, bem como a subjetividade e discricionariedade inerentes à sua forma de instituição. $\mathrm{O}$ acordo de "abrandamento", ao invés de representar um estímulo à delação e à consequente destruição da ação criminosa dos cartéis, tem se revelado fator de inestimável risco ao delator.

A perspectiva de premiação do leniente consubstancia-se em algo incerto, calcado em elementos subjetivos, motivando-o à não celebração do acordo. Isto coloca em risco a eficácia do próprio instituto, prejudicando substancialmente a boa investigação dos delitos contra a ordem econômica e, em especial, o cartel.

Dentro desta discussão é que se coloca o tema do presente trabalho. O seu principal escopo é a análise crítica do novo instituto, de tal sorte que, a partir do estudo de seus reflexos penais e da identificação de suas falhas, seja possível adequá-lo ao ordenamento jurídico, para que passe a ser utilizado em absoluta consonância com os ditames constitucionais de um Estado Democrático de Direito.

Para tanto, o estudo será iniciado com breves considerações acerca da disciplina da Economia e seu crescente vínculo com o Direito, com a abordagem das denominadas Constituições Econômicas. A seguir, será objeto de estudo também a regulação da concorrência pelo Estado como meio de preservação do mercado, seus interesses e objetivos, situando a atual preocupação existente em relação às infrações econômicas que abalam a livre concorrência.

\footnotetext{
${ }^{6}$ Artigo 35-C, da Lei no ${ }^{\circ} 8.884 / 94$.
} 
Posteriormente, será examinada a importância da tutela penal da ordem econômica, com reflexões acerca do Direito Penal Econômico. Neste ponto, caberá a análise dos fundamentos da tutela penal da concorrência e, por consequência, dos ilícitos concorrenciais, sua estrutura e previsão normativa.

Em uma próxima etapa, proceder-se-á ao estudo do acordo de leniência, seu escorço histórico, suas características e sua previsão em ordenamentos alienígenas. Em seguida, após a abordagem das questões éticas que circundam o instituto, serão objeto de discussão os seus reflexos penais, de modo a permitir uma análise crítica sobre o acordo, suas falhas e inconstitucionalidades, sempre à luz dos impactos penais.

Por fim, terão lugar as propostas legislativas sobre o tema que tramitaram perante os órgãos do Poder Legislativo, bem como a recém-aprovada Lei ${ }^{\circ}{ }^{\circ} 12.529 / 2011$, ainda em período de vacatio legis, com as alterações que trouxe para o instituto em comento.

Diante das considerações e estudos apresentados, buscar-se-á fornecer uma contribuição com a sugestão de alterações à Lei de Defesa da Concorrência, a fim de adequar o Programa de Leniência aos princípios constitucionais, trazendo maior segurança ao delator, sem, entretanto, olvidar-se da finalidade a que se destina o instituto, isto é, intensificar o combate aos cartéis. 


\section{CAPÍTULO 1 DIREITO E ECONOMIA}

\subsection{Conceitos Básicos para a Economia: as Necessidades Humanas e a Lei da Escassez}

Inicialmente, antes que se proceda à exposição de um conceito sobre Direito, Economia ou até sobre Direito Econômico, é importante que algumas premissas básicas, facilmente extraídas de nosso cotidiano, sejam estabelecidas.

A primeira delas reside na questão da quantificação das necessidades humanas. $\mathrm{O}$ homem é um ser possuidor de inúmeras necessidades, algumas tão prementes que, se não forem satisfeitas oportuna e completamente, a própria existência do indivíduo estará comprometida. ${ }^{7}$ Não bastasse, tais necessidades tendem a se multiplicar ao infinito, tornando-se ilimitadas.

Por mais absurda que possa soar esta afirmativa em termos éticos, filosóficos e morais, sendo quase que unanimemente reprovável uma postura de busca constante de novos bens ou serviços, o exame dos fatos ao longo dos anos indica a validade dessa assertiva.

A respeito dessa ausência de limites, FABIO NUSDEO expõe:

\footnotetext{
"É inócuo, portanto, apelar-se para a ciência com o fim de definir um limite, um ponto final para a proliferação das necessidades, quer as individuais, quer as coletivas. Pode-se concordar que aquela simples tendência natural transformou-se agora numa compulsão com aceleração constante do ritmo secularmente lento. Mas isto não implica a possibilidade de se vislumbrar um ponto ou um estágio final para esta multiplicação. Caso algum dia se chegue a ele, não era por imposição de algum fato novo, externo a ela, como, por exemplo, um possível esgotamento dos recursos do planeta, tornando inviável, fisicamente, o atendimento a muitas das atuais necessidades." 8
}

\footnotetext{
${ }^{7}$ PINTO, Aníbal. Curso de economia: elementos de teoria econômica. P. 02.

${ }^{8}$ NUSDEO, Fabio. Curso de economia: introdução ao direito econômico. Pp. 24/25.
} 
Por outro lado, ao contrário do que ocorre com as necessidades humanas, os recursos existentes para satisfazê-las são inquestionavelmente limitados, embora os homens se esforcem para tentar postergar essas fronteiras ou, ao menos, seus pontos de ruptura.

Ainda que se consiga adiar o exaurimento dos bens disponíveis, esta será apenas uma forma de administrar os recursos escassos e não uma solução definitiva do problema, pois serão eles sempre escassos, em menor ou maior grau, por mais ou menos tempo.

Essa é a chamada lei da escassez,

“[...] uma lei férrea e incontornável, tendo submetido os homens ao seu jugo desde sempre, levando-os a se organizarem e a estabelecerem entre si relações específicas a fim de enfrentá-la ou, melhor falando, conviver com ela, atenuando-lhe o quanto possível a severidade." 9

A esse ponto, é essencial comparar as sociedades primitivas e a moderna sociedade de consumo, destacando a falsa impressão que se tem, hoje, no que tange à eliminação da escassez dos bens e serviços.

Ressalta-se que o conceito de escassez é relativo e não absoluto, pois decorre diretamente da maior ou menor procura pelo recurso. Isto significa que um produto ou recurso qualquer, mesmo sem ter alterações em sua disponibilidade física, pode se tornar mais ou menos escasso, de acordo com a necessidade que lhe compete atender. A escassez só existe porque há procura para o bem, que tem uma utilidade suscetível de atender determinada necessidade dos consumidores e um produto só torna-se um bem econômico, porque satisfaz uma necessidade humana. Logo, um bem econômico vem a ser todo aquele bem útil e escasso.

Diante dessa regra, o consumidor é soberano e, como tal, deve decidir qual será a composição de sua cesta de consumo, de acordo com as suas preferências, necessidades e a renda de que dispõe. ${ }^{10}$

\footnotetext{
${ }^{9}$ Idem, ibidem, p. 25.

${ }^{10}$ SOUZA, Nali de Jesus. Curso de economia. P. 19.
} 
Nesse contexto, em que de um lado se tem o crescimento incessante de necessidades e de outro a escassez de recursos, surge o denominado sistema econômico, constituído de regras, relações e instituições criadas com o propósito de disciplinar a forma por meio da qual o homem lida com esse problema.

A partir dessas premissas, serão traçadas breves linhas conceituais sobre a ciência da Economia.

Para os economistas clássicos, como AdAM SMITH, DAVID RICARdo e JOHN STUART MiLl, a Economia é o estudo do processo de produção, distribuição, circulação e consumo dos bens e serviços. Sob outro ponto de vista, para os seguidores do pensamento econômico neoclássico, a Economia pode ser definida como a ciência das trocas ou escolhas, de modo a lidar com o comportamento humano condicionado pela escassez dos recursos. É a ciência que trata da relação entre fins e meios (escassos) disponíveis para atingi-los. Modernamente, ela é definida como “[...] a ciência que estuda o emprego de recursos escassos, entre usos alternativos, com ofim de obter os melhores resultados, seja na produção de bens, ou na prestação de serviços." 11

À luz deste conceito é que serão abordados os tópicos seguintes.

\subsection{Liberalismo Econômico}

A fim de estudar a disciplina jurídica da atividade econômica e adentrar nos estudos do Direito Econômico, é recomendável que se examine a atuação do Estado após o período liberal. Mas, para que se compreenda esse momento, mister se faz serem observadas as condições em que se desenvolvia a atividade econômica no próprio Estado Liberal.

À guisa de introdução, nos dizeres de ERos Roberto GraU, “[...] o liberalismo consubstancia um movimento de reação ao corporativismo, ensejado por circunstâncias de ordem econômica." 12

O termo também foi estudado por THEODORE MEYER GREENE:

\footnotetext{
${ }^{11}$ Idem, ibidem, p. 15.

${ }^{12}$ GRAU, Eros Roberto. Elementos de direito econômico. P. 16.
} 
“[...] sugere pelo menos por associação histórica, o supremo valor a liberdade como condição primordial para a criatividade do indivíduo e a solidariedade de uma sociedade livre e a ameaça fundamental que a escravidão oferece a todas as aspirações e progressos humanos. Evidencia a vida do espírito e seus supremos valores sem que isso implique nosso compromisso com qualquer formulação dogmática desses valores ou quaisquer meios específicos para sua realização. (...) A atitude liberal é a expressão natural da fé na liberdade." 13

Um terreno fértil à doutrina do liberalismo criou-se com a Revolução Francesa, fruto da ascensão da burguesia, uma classe que possuía ideais e interesses próprios. A acessibilidade à utilização de novas fontes de energia e de matéria-prima e a emancipação da produção à tradição definitivamente abriram espaço para essa doutrina a serviço dos interesses da burguesia.

Diante desses novos interesses, o Estado passou a exercer papel absolutamente restrito diante dos fatos econômicos e sociais, encontrando barreiras para qualquer posição mais ofensiva.

Porém, anteriormente à Revolução Francesa, a confluência de quatro eventos históricos, todos em 1776, trouxeram para primeiro plano a ideia de liberdade, provocando intensas mudanças políticas, sociais e econômicas. ${ }^{14}$

No campo político, deu-se naquele ano a independência americana, surgindo, pela primeira vez, uma nação inteiramente fundada nos princípios da liberdade, com organizações política e econômica próprias para tanto.

Na seara econômica, foi publicado o livro A riqueza das nações, de Adam Smith, que traz os fundamentos de uma ciência econômica absolutamente independente. Com base na filosofia utilitarista, o autor lançou a ideia da mão invisível, que levaria os bens escassos aos seus pontos ótimos de aplicação, garantindo aos cidadãos o direito de escolher, mediante o sistema de preços, os produtos e serviços dos quais pretendesse usufruir.

\footnotetext{
${ }^{13}$ GREENE, Theodore Meyer. Liberalismo: teoria e prática. Pp. 30/31.
}

${ }^{14}$ NUSDEO, Fabio. Op. cit., p. 126. 
Na esfera jurídica, foi editado na França o Décret d'allarde, pelo qual foram extintas as corporações de ofício, estabelecendo-se a liberdade de todo o cidadão de exercer a profissão de sua escolha, sem a obrigação de filiar-se a qualquer organização ou entidade nem de ser por elas licenciado.

No âmbito tecnológico, iniciou-se nos Estados Unidos da América a mecanização da indústria têxtil com a aplicação do princípio da máquina a vapor. Com isso, deflagrouse a Revolução Industrial, um contínuo processo de aplicação do conhecimento científico às atividades produtoras que ocorre até hoje.

Nesse particular, paulatinamente foi se solidificando o pensamento liberal, segundo o qual os agentes econômicos são movidos pelo espírito hedonista, ou seja, buscam maximizar os resultados obtidos por meio de sua atividade com o mínimo de investimentos, recursos e horas de trabalho.

Convém registrar que tais agentes não atuam isoladamente, ao contrário, comunicam-se intensamente em um ambiente comum, o mercado, onde interagem forças de oferta e procura, as quais, somadas ao sentimento hedonista, são suficientes para estabelecer os preços de cada produto e serviço, dispensando a atuação de uma força externa para regular a economia. O mercado seria regulado pela mão invisível, sem qualquer intervenção de regras exteriores.

Por outro lado, a doutrina essencial do liberalismo econômico consistiu em asseverar que a cooperação social e a divisão do trabalho só poderiam ser alcançadas em um sistema em que a ordem econômica estivesse baseada na propriedade privada dos meios de produção, logo, rechaçou a propriedade pública destes meios.

Com base nessas diretrizes, o Estado Liberal caracterizou-se pela ideia do laissez faire, laissez passer, isto é, pela liberdade de produção e de comércio, exaltando a livre concorrência. O pensamento econômico daquela época fez transparecer a consagração da liberdade de iniciativa, traduzida na busca do interesse individual e, como consequência, do interesse coletivo.

Porém, o liberalismo, como regime econômico, não parecia apresentar caminhos para evoluir. Não bastassem as crises, o conflito entre capital e trabalho e o comprometimento do ideal de mercado livre levaram-no ao insucesso. A burguesia de um 
lado e a força de trabalho organizada de outro exigiam correções no regime econômico, em nome de uma proteção ao sistema capitalista. A liberdade indiscriminada da indústria e do comércio provocou situações de totalitarismo econômico.

$\mathrm{O}$ surgimento das chamadas economias de guerra no século XX contribui para o fracasso do liberalismo econômico, pois algumas nações tiveram de se preparar para o esforço bélico, o que exigiu uma mobilização econômica nesse sentido, de modo a ampliar as atribuições do Estado. Com as duas guerras mundiais e a Grande Depressão, em 1929, o liberalismo econômico não conseguiu mais se sustentar, tanto que o Estado, aos poucos, foi forçado a abandonar a posição de passividade, passando a corrigir distorções que comprometiam o sistema.

Essa assunção pelo Estado de funções interventivas sobre o processo econômico tornou-se possível na medida em que uma marcante evolução nos estudos da Economia se operou. Para ERos GrAU, esta evolução transporta-nos da Economia Política à Política da Economia, pois altera radicalmente a postura assumida pelo estudioso desta ciência, que deixa simplesmente de descrever o processo econômico para prescrever-lhe medidas corretivas e soluções de conformação. ${ }^{15}$

Do Estado Liberal, portanto, caracterizado pela destinação exclusiva à preservação da ordem, da segurança e da paz, passou-se ao chamado Estado Social, destacando-se como instrumento de justiça social e de desenvolvimento. Cabe aqui ressaltar, contudo, que essa transformação não ocorreu repentinamente. Em um primeiro momento, conhecido como neoliberal, há a pressuposição da livre concorrência das forças de mercado, que o Estado deve assegurar como o melhor caminho para a realização dos interesses sociais. Mas já se admite a necessidade da intervenção do Estado para a restauração do equilíbrio natural na concorrência.

O Estado neoliberal é marcado pela busca a uma economia de mercado sem limites, por dedicar especial atenção à atividade econômica em detrimento das atividades social e política.

Somente após essa etapa é que surge o momento social, admitindo-se que não há coerência entre o interesse social e o livre jogo das forças de mercado. O Estado passa a se

\footnotetext{
${ }^{15}$ GRAU, Eros Roberto. Elementos de direito econômico. p. 18.
} 
responsabilizar pelo processo econômico e, para tanto, define políticas e diretrizes. ${ }^{16}$ Uma ação sistemática é adotada sobre a economia, surgindo, pois, a disciplina jurídica da atividade econômica, questão a ser tratada em tópico posterior do presente trabalho.

A fim de melhor contextualizar e justificar essa regulamentação jurídica da atividade econômica, passar-se-á ao estudo das falhas do mercado.

\subsection{Falhas do Mercado}

As falhas ou imperfeições do mercado foram se positivando ao longo de cerca de 150 anos, quando, então, se tentou operacionalizar o mercado com base em uma estrutura institucional relativamente simples, assentada no tripé Constituição, Códigos de Direito Privado e Poder de Polícia.

Todos esses anos de aplicação ou tentativa de aplicação do chamado figurino liberal produziram um quadro conturbado, embora o progresso e o desenvolvimento da atividade econômica tivessem sido notáveis. ${ }^{17}$

Aos poucos, em grande parte impulsionada pelos desafios políticos, a análise econômica foi submetendo os mecanismos de funcionamento do mercado a críticas, prevalecendo a conclusão segundo a qual o mercado é viável e operacional. No entanto, essa operacionalidade dependeria de diversos pressupostos que a estrutura própria do liberalismo não havia logrado captar, de modo que, com a ausência deles, a mecânica operacional do sistema passou a produzir resultados falhos. ${ }^{18}$

Nesse passo, é mister compreender que as falhas de mercado não significam, necessariamente, que o mercado não exista, elas indicam apenas que o mercado não produz resultados eficientes. Para examiná-las, parte-se de uma classificação de seis espécies de falhas, quais sejam: a mobilidade dos fatores de produção, o acesso a informações relevantes, a concentração econômica, as externalidades, os bens coletivos e os custos de transação.

\footnotetext{
${ }^{16}$ Idem, ibidem.

${ }^{17}$ NUSDEO, Fabio. Op. cit., p. 139.

${ }^{18}$ Idem, ibidem.
} 


\subsubsection{Mobilidade dos fatores de produção}

Para a funcionalidade dos mercados sempre se presumiu que os fatores de produção eram dotados de mobilidade, para justamente reagirem a sinais indicativos do mercado, representados, basicamente, pelos preços. Em curto tempo, os sinais promoveriam os deslocamentos cabíveis, a fim de se reverterem situações indesejáveis automaticamente (o denominado automatismo).

Mas, na prática, essa agilidade não existe, o que provoca uma falha de mercado. Ao reverso, há “[...] uma rigidez mais ou menos pronunciada em quase todos os fatores, impedindo-lhes esses deslocamentos céleres, automáticos e oportunos. Rigidez de toda ordem: física, operacional, institucional, psicológica." 19

Essa falha é facilmente percebida nos produtos agrícolas. Apesar de a alta de seus preços exigir elevação imediata de suas plantações, os produtos agrícolas levam vários anos para entrar em fase de produção comercial. Mesmo quando isso ocorre, é possível que sobrevenha uma superprodução no mercado, provocando baixa nos preços.

Em paralelo, a maioria dos produtos agrícolas consiste em cultura permanente e, independentemente de seu preço, uma safra nova é produzida a cada ano - em maior ou menor quantidade -, que é adicionada ao estoque anterior, forçando, ainda mais, os preços para baixo. Se levada ao limite essa situação, a única solução é erradicar as plantações, substituindo-as, o que não se faz sem altíssimos custos. Nesses casos, são sérias as consequências micro e macroeconômicas.

\subsubsection{Acesso às informações relevantes}

Outro pressuposto do sistema descentralizado consiste no acesso de todos os operadores do mercado às informações a respeito do mesmo e sobre as características dos produtos e serviços nele negociados.

\footnotetext{
${ }^{19}$ Idem, ibidem, p. 140.
} 
Sempre se acreditou nas informações transmitidas pelos preços, isto é, que eles continham em si a informação relevante essencial para os agentes interessados; seria o sinal inconfundível da escassez ou abundância, de acordo com a alta ou baixa dos preços.

De fato, preços e mercados são a base do sistema de incentivos da economia. Porém, há alguns problemas de informação que o mercado não resolve ou não resolve bem. A informação imperfeita, não raro, inibe a capacidade dos mercados de executar as tarefas que lhe cabem. ${ }^{20}$

GEORGE A. AKERLOF ilustrou a questão com um exemplo real - o mercado de carros usados (lemons):

\begin{abstract}
"After owning a specific car, however, for a lenght of time, the car owner can form a good idea of the quality of this machine; i. e., the owner assigns a new probability to the event that this car is a lemon. This estimate is more accurate than the original estimate. An assimetry in available information has developed: for the sellers now have more knowledge about the quality of a car than the buyers. But good cars and bad cars must still sell at the same price since it is impossible for a buyer to tell the difference between a good car and a bad car. It is apparent that a used car can not have the same valuation as a new car - if it did have the same valuation, it would clearly be advantageous to trade a lemon at the price of new car, and buy another new car, at a higher probability $q$ of being good and a lower probability of being bad. Thus the owner of a good machine must be locked in. Not only is it true that he cannot receive the true value of his car, but he cannot even obtain the expected value of a new car." 21
\end{abstract}

\footnotetext{
${ }^{20}$ STIGLITZ, Joseph E.; WALSH, Carl E. Op. cit., p. 193.

${ }^{21}$ Tradução livre: "Após adquirir um carro específico, contudo, por um período, o seu proprietário pode formar uma boa ideia sobre a qualidade desta máquina específica, isto é, ele determina uma nova probabilidade para o fato de seu carro ser um 'abacaxi'. Essa estimativa é mais precisa que a original. Uma assimetria nas informações disponíveis desenvolveu-se, pois os vendedores têm agora mais conhecimento com relação à qualidade de um carro do que os compradores. Mas os carros bons e os ruins continuarão sendo vendidos pelo mesmo preço, uma vez que é impossível para um comprador diferenciar um carro bom de um outro ruim. É manifesto que um usado não pode ter o mesmo valor que um novo - se assim o fosse, seria claramente mais vantajoso trocar o 'abacaxi' pelo preço de um carro novo e, então, comprar outro novo, com uma probabilidade $q$ maior de este último ser um bom carro e uma possibilidade menor de ser um carro ruim. Assim, o proprietário de uma boa máquina fica acorrentado. Não só é verdade que ele pode não receber o verdadeiro valor por seu carro, como também ele pode não obter o valor esperado por seu carro." (AKERLOF, George A. The market for "lemons": quality uncertainty and the market mechanism. The Quartely Journal of economics. MIT Press).
} 
A situação descrita caracteriza-se pela informação assimétrica entre vendedores e compradores, pois estes últimos não conseguem saber exatamente quais são os carros que apresentam defeitos e quais os que se encontram em bom estado de conservação, o que leva a um quadro de diminuição de vendedores e compradores em comparação a um mercado regido por informações perfeitas. ${ }^{22}$

Consequentemente, a assimetria de informações atinge de forma contundente as noções de preço e qualidade enquanto sinais de mercado, de modo a provocar um efeito de seleção adversa. A qualidade da oferta diminui à medida que o preço reduz, pois, com os valores de oferta baixos, o número daqueles que optam por vender diminui. ${ }^{23}$

\subsubsection{Concentração econômica}

Para os liberalistas, a fim de que se pudesse construir um sistema de mercado perfeito, era necessário que a sua estrutura fosse composta por um número razoavelmente elevado de compradores e vendedores em interação recíproca e nenhum deles excessivamente importante ou com atuação relevante. Era a chamada atomização. ${ }^{24}$

Destaca-se que esta importância era avaliada de acordo com a posição que o agente econômico ocupava em relação aos demais e qual a sua capacidade de influir nas condições de mercado.

Esse pressuposto não estava, à época em que foi elaborado, tão distante da realidade, eis que, ao final do século XVIII, as unidades de produção eram pequenas e utilizavam instrumentos rudimentares. No entanto, logo após a Revolução Industrial, esta realidade mudou, mormente com o surgimento das economias de escala, as quais trouxeram, sim, inúmeras vantagens ao consumidor em razão da baixa de preços; em contrapartida, criou um grande problema aos produtores, já que possibilitou o surgimento de um seleto grupo com recursos suficientes para ampliar seus negócios e conquistar grandes fatias do mercado anteriormente ocupadas por pequenos produtores. Ao final, ao

\footnotetext{
${ }^{22}$ STIGLITZ, Joseph E.; WALSH, Carl E. Op. cit., p. 240.

${ }^{23}$ GABAN, Eduardo Molan. Assimetria de informação e barreiras à livre concorrência. P. 92.

${ }^{24}$ NUSDEO, Fabio. Op. cit., p. 170.
} 
invés de muitos produtores com pequeno prestígio no mercado, havia poucos fabricantes com grande importância, isto é, um oligopólio.

Com essas mudanças, o poder desse restrito grupo passa a ser cada vez mais evidente, porquanto há uma influência direta na formação do preço de determinados produtos. Nesse contexto, não necessariamente a alta de preços decorrente de grande procura levará a um aumento da oferta. Isto porque é bem mais fácil que os poucos agentes no mercado se unam, formando um conluio, e elevem ainda mais os preços. Da mesma maneira, sem que a curva da demanda sofra qualquer alta, os agentes econômicos ajustados podem manejar uma grande alta nos preços a seu bel-prazer.

Assim é que surgem outras formas de concentração econômica, tais como o cartel, ensejando a elaboração, em diversos países, de legislações antitruste, que buscam coibir os excessos trazidos pela concentração de poder econômico dos agentes de mercado.

Vale ressaltar que as causas da concentração econômica podem ser vistas não só nas economias de escala, mas também nos monopólios ou oligopólios derivados de situações de fato, como uma fonte de matéria-prima rara ou uma condição tecnológica exclusiva como a patente de invenção. ${ }^{25}$ Seja qual for a sua origem, a concentração econômica representa uma grande falha de estrutura do sistema de mercado, uma vez que a estrutura prevista para o seu funcionamento tende a não mais corresponder àquela verificada na maioria dos mercados.

\subsubsection{Externalidades}

Elas representam uma falha de sinal baseada no pressuposto de que os custos e benefícios de qualquer atividade serão apropriados pelas unidades responsáveis. Quando este pressuposto deixa de ocorrer, alguns fatores escassos passam a ser utilizados gratuitamente.

De fato, sempre que um indivíduo ou uma empresa levar adiante uma ação que afeta outros diretamente, sem pagar nada por ela e nem mesmo receber qualquer compensação, está presente uma externalidade (o efeito da ação é externo ao indivíduo ou

\footnotetext{
${ }^{25}$ Idem, ibidem, p. 149.
} 
à empresa). As externalidades representam, portanto, custos ou benefícios que circulam externamente ao mercado, sem haver qualquer compensação, pois não é possível, para eles, estipular um preço. Assim, as externalidades podem ser entendidas como "[...] instâncias em que o sistema de preços funciona de modo imperfeito." 26

Quando há externalidades, a alocação de bens pelo mercado acaba por ser ineficiente, pois o produtor não considera o custo social ao decidir o quanto produzir. Se o preço pago pelo consumidor não reflete inteiramente o custo de produzir o bem, ele demandará maior quantidade do produto e serão produzidos bens em excesso. Se houver benefícios sociais além dos benefícios privados dos consumidores, a produção será baixa demais.

FABIO NUSDEO exemplifica claramente a questão apresentando uma analogia entre as externalidades e uma barreira de pedágios de estradas:

\begin{abstract}
"Para passar por ela, é preciso pagar o preço. No entanto, se a barreira não for bem construída e instalada, poderão alguns carros se valer de um atalho e elidi-la, safando-se sem o correspondente custo. Claramente, eles estarão em situação favorecida frente aos demais. A isso os ingleses chamam de free rider, cuja tradução seria o passageiro gratuito (ou carona), denominação muito encontrada na literatura sobre o assunto. Mas, além disso, os responsáveis pela estrada estarão recebendo uma informação incorreta sobre o exato número dos seus usuários. Daí a falha de sinal." 27
\end{abstract}

É importante que se mencione a existência de externalidades negativas e positivas. As primeiras são aquelas que transferem custos aos demais e as últimas as que transferem benefícios incompensadamente a terceiros. Sejam negativas ou positivas, elas levam a ineficiências de mercado e, por essa razão, acabam por se tornar justificativas para a intervenção do Estado nos mercados. Na hipótese de ela ser positiva, por exemplo, o

\footnotetext{
${ }^{26}$ STIGLITZ, Joseph E.; WALSH, Carl E. Op. cit., p. 189.

${ }^{27}$ NUSDEO, Fábio. Op. cit., p. 153.

Joseph E. Stiglitz e Carl E. Walsh apresentam outros exemplos a fim de ilustrar o conceito: “Um pedestre ou alpinista que joga lixo no ambiente, um motorista cujo carro emite poluentes, uma criança que deixa o quarto na bagunça quando termina de brincar, alguém que fuma um cigarro numa sala cheia de gente, um estudante que fala durante a aula - todos criam externalidades. Em cada caso o autor não é o único a sofrer as conseqüências de seu ato; outros também sofrem as conseqüências [...]" e ainda a "[...] fábrica que emite poluentes no ar. A fábrica se beneficia da poluição, na medida em que pode produzir seu produto de forma mais barata do que se instalasse equipamento para controlar as emissões.” (Op. cit., pp. 189 e 194).
} 
Governo pode implementar medidas que visem a ampliação da oferta de bens e serviços, considerando que o nível de mercado de produção é baixo demais. Já no caso de ela ser negativa, o Governo pode prevenir o excesso de produção de bens mediante a regulação por lei ou com a criação de incentivos. ${ }^{28}$

\subsubsection{Bens coletivos}

Estes bens são definidos por FABIO NUSDEO como aqueles “[...] aptos ao atendimento simultâneo das necessidades de um grupo ou coletividade para os quais não vigora o princípio da exclusão no ato de seu uso ou do seu consumo.” ${ }^{29}$ Eles representam casos extremos de externalidades. Isto significa que o custo marginal de oferecê-los a uma pessoa adicional é rigorosamente zero (ausência de rivalidade de consumo) e o custo de excluir alguém de seu uso é proibitivo (impossibilidade de exclusão). ${ }^{30}$ Ao contrário, os bens exclusivos são aqueles que, se utilizados por alguém, outros consumidores já estão automaticamente impedidos de utilizá-los. A título de exemplo, tem-se as estradas, porquanto vários motoristas podem servir-se simultaneamente desses bens sem que o seu uso exclua os demais.

No mercado, é importante que os agentes econômicos possuam a tendência de esconder a sua preferência pelos bens coletivos, visto que estes não carregam consigo a exclusividade do uso.

Com os consumidores ocorre a preferência revelada, isto é, a priorização dos bens por eles adquiridos em razão de terem sido disputados no mercado e em troca de uma parcela de sua renda. Eles sabem que, se colaborarem financeiramente para a realização de qualquer iniciativa/produção coletiva, sua participação será insignificante e dela não dependerá a sua materialização. Ademais, quando disponíveis os bens, terceiros que deixaram de colaborar com a sua produção receberão os mesmos benefícios.

Por isso, os consumidores escolhem os artigos que desejam ver produzidos (princípio da soberania do consumidor) e ditam, de certo modo, as regras do mercado.

\footnotetext{
${ }^{28}$ STIGLITZ, Joseph E.; WALSH, Carl E. Op. cit., p. 195.

${ }^{29}$ NUSDEO, Fábio. Op. cit., p. 161.

${ }^{30}$ STIGLITZ, Joseph E.; WALSH, Carl E. Op. cit., p. 189.
} 
Essa situação acaba por provocar uma grande falha no mercado: a tendência de se dar a discriminação dos bens coletivos e o exagero na produção de bens exclusivos. Não é por outra razão que, atualmente, é relevante o grande número de veículos particulares circulando pelas ruas, em contraposição à escassez e à má qualidade dos transportes públicos. Casos como este podem levar ao chamado fenômeno da causação circular, ou seja, quanto pior o transporte coletivo, mais se exacerba a procura por veículos particulares.

\title{
1.3.6 Custos de transação
}

Tais custos são definidos como

\begin{abstract}
"[...] aqueles custos necessários para realizar uma transação no mercado, ao invés de realizá-la no interior da empresa. (...) Esses custos consistem basicamente na incerteza que caracteriza as relações de mercado (que se estendem desde os preços até a natureza e características do produto a ser fornecido) e no fato de que as transações são realizadas freqüentemente com pequena possibilidade de escolha, sendo limitado o número de compradores." 31
\end{abstract}

Para abordar essa falha de mercado, é interessante relembrar que os neoclássicos, ao falarem em operações no mercado, traduziam-nas de maneira muito simplista, como se elas fossem instantâneas e independentes umas das outras. Mas não é isso que nos revela a realidade. Nem sempre são independentes e, muito menos, instantâneas. A sua concretização impõe uma série de custos, como: exame de qualidade dos produtos, preparo, monitoramento e execução de contratos, contratação e manutenção de mão de obra, dentre outros. Igualmente, exige o funcionamento de instituições ancilares para várias operações como consultoria legal e serviços notariais.

Embora tais custos tenham sido esquecidos pela teoria neoclássica - mesmo porque àquela época eles deviam ser quase irrelevantes em comparação com os dias atuais -, eles são revelados no dia a dia do mercado.

\footnotetext{
${ }^{31}$ SALOMÃO FILHO, Calixto. Direito concorrencial - as condutas. P. 29.
} 
Para FABIO NuSDEO, os referidos custos não são desprezíveis e decorrem das instituições. Segundo o autor,

\begin{abstract}
"Eles decorrem, essencialmente, do funcionamento das instituições, o que difere amplamente de país para país. Como é sabido, as instituições vêm a ser as "regras do jogo" destinadas a conferir um mínimo razoável de estabilidade, previsibilidade e segurança nas relações entre os cidadãos. Elas impõem restrições à sua liberdade de agir e de decidir, manifestando-se essencialmente por um conjunto de normas, não necessariamente jurídicas e nem necessariamente escritas." 32
\end{abstract}

Essas instituições são absolutamente imprescindíveis, porém, variam, e muito, em termos de eficiência. Enquanto algumas conseguem estimular a atividade econômica, reduzindo os custos de transação, outras apresentam uma série de obstáculos, seja pela burocracia que impõem, seja pela corrupção que assola seus trabalhos, seja, ainda, pela imprecisão de seus atos normativos, de modo que os custos são agravados. ${ }^{33}$

Feitas essas ponderações, torna-se praticamente impossível falar-se, atualmente, em custos de produção. A eles devem sempre ser acrescidos os chamados custos de transação, valores estes capazes de distorcer em absoluto os custos iniciais.

Essa falha dos custos transacionais decorre diretamente de uma esquematização simplória dos pressupostos de análise, somado a um mau funcionamento das instituições. ${ }^{34}$

\title{
1.4 Direito Econômico
}

"La tarea de definir el Derecho económico no es fácil, pues no basta referirlo genericamente a lo económico, pues con este critério amplíssimo vendría a acaparar y reunir temas tan dispares como el regimen de la propriedad, el contrato de compraventa, el hurto y las defraudaciones, etc." 35

\footnotetext{
${ }^{32}$ NUSDEO, Fabio. Op. cit., p. 166.

${ }^{33}$ Idem, ibidem.

${ }^{34}$ Idem, ibidem.

${ }^{35}$ AFTALIÓN, Enrique R. Derecho penal económico. P. 18.
} 
O Direito Econômico começou a despontar em meados do século XIX, no momento em que o capitalismo atomista viu-se transformar em um capitalismo de grupo. A denominada concentração capitalista provocou inúmeras influências no Direito, de modo a fazer surgir um novo ramo para reger o atual fato econômico. ${ }^{36}$

Nesse sentido, as empresas, com o firme propósito de acabarem com as incertezas do mercado, buscaram maximizar seus ganhos, fortalecendo-se em grupos. Surgiu, então, o poder econômico privado em contraponto ao poder estatal.

O início do século XX veio demarcar uma profunda alteração nos rumos do Direito. Uma nova postura do Estado e, consequentemente, do Direito foi forçada em virtude da transformação sofrida pelo Direito proveniente do movimento iluminista, dos efeitos da Primeira Guerra Mundial e, por fim, do colapso sofrido pela crença no automatismo dos processos do liberalismo. ${ }^{37}$

Por certo, os instrumentos que vinham sendo adotados pelo Direito, baseados na estrutura racionalista do pensamento iluminista, mostraram-se absolutamente inadequados para enfrentar os problemas trazidos pela Revolução Industrial, decorrentes da materialidade da ordem econômica. Já a Primeira Guerra Mundial, com a destruição de toda a Europa, trouxe a necessidade de uma reconstrução marcante com diretrizes radicalmente diferentes daquelas adotadas até então. Do mesmo modo, a crise do liberalismo contribui para a convicção de que o Estado deveria conduzir o fenômeno econômico com instrumentos mais adaptados à realidade.

As Constituições do México e de Weimar surgiram como respostas às novas exigências de um Direito novo que fosse eficaz e eficiente para o Estado dirigir as novas realidades econômica e social.

A Segunda Guerra Mundial, da mesma forma, foi um grande marco para a evolução do Direito, porquanto representou uma nova realidade que revelava a necessidade de o Estado se dedicar mais para a direção da economia. Chegava ao fim a crença na ordem natural da economia para dirigir os fenômenos econômicos.

\footnotetext{
${ }^{36}$ FONSECA, João Bosco Leopoldino da. Direito econômico. P. 06.

${ }^{37}$ Idem, ibidem, p. 08.
} 
Diante dessa carência de mudança e de um novo tipo de relações pertinentes para o dever-ser, torna-se essencial um conjunto de normas jurídicas para discipliná-lo e conduzilo. Isto porque “[...] o fato econômico se apresenta de forma diferente, e o Direito se curva sobre ele para moldá-lo às novas instituições ideológicas. "38 Era o Direito procurando direcionar o econômico e, daí, Direito Econômico, o qual surge no momento em que da Economia política passa-se à Política econômica. Direito Econômico é, pois, “[...] o Direito da política econômica - de uma política que projeta em concreção momentos de uma determinada ideologia econômica. "39 Com base nessa interpretação, Washington Peluso Albino DE SouZA buscou defini-lo como

\footnotetext{
“[...] o ramo do Direito, composto por um conjunto de normas de conteúdo econômico e que tem por objeto regulamentar as medidas de política econômica referentes às relações e interesses individuais e coletivos, harmonizando-as, pelo princípio da 'economicidade', com a ideologia adotada na ordem jurídica." ${ }^{40}$ (grifos do autor)
}

Para JoÃo Bosco LeOPOldino dA FonseCA, o Direito Econômico é “[...] constituído por um corpo orgânico de normas condutoras da interação do poder econômico público e do poder econômico privado e destinado a reger a política econômica." ${ }^{41}$

Já considerando o aspecto da linguagem do Direito, assim como o é da metalinguagem, J. SIMÕES PATRÍCIO conceitua:

\footnotetext{
"Direito Econômico é o sistema de normas - ou a disciplina jurídica que as estuda - que regulam:

(i) A organização da economia, designadamente definindo o sistema e o regime econômicos;
}

\footnotetext{
${ }^{38}$ Idem, ibidem, p. 07.

${ }^{39}$ GRAU, Eros Roberto. Elementos de direito econômico. P. 23.

${ }^{40}$ SOUZA, Washington Peluso Albino. Direito econômico. P. 3.

$\mathrm{Na}$ mesma linha, segue o conceito elaborado por FÁBIO KONDER COMPARATO: “[...] o novo Direito Econômico surge como o conjunto de técnicas jurídicas de que lança mão o Estado contemporâneo na realização de sua política econômica." (COMPARATO, Fábio Konder. O indispensável direito econômico. P. 465.)

${ }^{41}$ FONSECA, João Bosco Leopoldino da. Direito econômico. P. 19.
} 
(ii) A condução ou controle superior da economia pelo Estado, em particular estabelecendo o regime das relações ou do 'equilíbrio de poderes' entre o Estado e a economia (os agentes econômicos, maxime os grupos de interesses concentrados); e

(iii) A disciplina dos centros de decisão econômica não estaduais, especialmente enquadrando, macroeconomicamente, a atividade das instituições fundamentais." 42

Apesar de a norma jurídica surgir dos fatos econômicos, acaba, muitas vezes, por condicioná-los e determiná-los. Assim, o Direito deixa de ser um simples elemento de natureza estrutural para cumprir um papel verdadeiramente funcional.

É por meio das normas de Direito Econômico que o Estado introduz variáveis compulsórias ou facultativas ao pensamento do agente econômico, destinadas a influenciar diretamente em suas decisões. Nem sempre tais variáveis são criadas segundo interesses coletivos, mas sim de acordo com os interesses estatais decorrentes de outros, públicos. ${ }^{43}$

Nesse segmento, pode-se afirmar que o propósito do Direito Econômico consiste em garantir a organização e o funcionamento da economia - o que pressupõe a correção das falhas de mercado já apontadas em capítulo anterior - em bases e com técnicas que, instituindo a primazia do interesse econômico geral, não suprimam a atividade lucrativa dos particulares. ${ }^{44}$

No Brasil, o ordenamento jurídico consagra o Direito Econômico em nível constitucional ao prever, no artigo 24, inciso I da Carta Magna, que "Compete à União, aos Estados e ao Distrito Federal legislar concorrentemente sobre: I - direito tributário, financeiro, penitenciário, econômico e urbanístico [...]”.

É indubitável que a intervenção estatal na economia manifeste-se por meio de leis e regulamentos, atuando o Poder Público como fiscal de toda a ordem econômica. Esse constante expansionismo normativo, que tenta acompanhar a intensa velocidade em que caminha o surgimento de novos fenômenos econômicos, não fica restrito somente ao

\footnotetext{
${ }^{42}$ PATRÍCIO, J. Simões. Curso de direito econômico. Pp. 76/77. Apud FONSECA, João Bosco Leopoldino da. Direito econômico. P. 18.

${ }^{43}$ AGUILLAR, Fernando Herren. Direito econômico: do direito nacional ao direito supranacional. P. 02.

${ }^{44}$ GOMES, Orlando e ANTUNES, Varela. Direito econômico. P. 05.
} 
campo econômico, invadindo também a seara penal, com a criminalização de inúmeras condutas.

\subsection{Ordem Econômica}

Originariamente, a expressão ordem econômica aparece na primeira metade do século XX, sob influência das reações às políticas econômicas liberais, quando as constituições passaram a regulamentá-la, especialmente a partir das Constituições Mexicana de 1917 e de Weimar de 1934.

A definição de seu conceito não é assim tão clara, razão pela qual os estudiosos encontram diversos significados que lhe podem ser atribuídos. Contudo, a análise de sua conceituação é essencial, considerando não só o marco que representa no relacionamento entre Direito e Economia, mas também por definir o objeto de alguns dos crimes previstos na Lei $n^{\circ} 8.137 / 90$, em especial, o delito de formação de cartel.

Dentre os inúmeros significados da palavra ordem encontram-se: disposição conveniente dos meios para se obterem os fins, disposição metódica, arranjo de coisas segundo certas relações, boa disposição, bom arranjo, arrumação, lei estabelecida, boa administração e conjunto sistêmico de princípios de organização. ${ }^{45}$ Neste último sentido, pode se referir a uma ordem jurídica, ou pública, privada, ou mesmo econômica e social, entre outras. ${ }^{46}$ É essa multiplicidade de significados da palavra ordem que torna complexa a sua definição exata e o delineamento da expressão ordem econômica.

LUIZ REGIS PRADO apresenta o conceito de ordem econômica sob duas formas: estrita e ampla. Na primeira,

\footnotetext{
“[...] entende-se por ordem econômica a regulação jurídica da intervenção do Estado na economia; na segunda, mais abarcante, a ordem econômica é conceituada como a 'regulação jurídica da produção, distribuição e consumo de bens e serviços'."
}

\footnotetext{
${ }^{45}$ FERREIRA, Aurélio Buarque de Holanda. Dicionário Aurélio da língua portuguesa. P. 468.

${ }^{46}$ GRAU, Eros Roberto. Elementos de direito econômico. P. 40.
} 
Assim,

“[...] a noção de ordem econômica 'lato sensu', apreendida como ordem econômica do Estado (...) abrange a intervenção estatal na economia, a organização, o desenvolvimento e a conservação dos bens econômicos (inclusive serviços), bem como sua produção, circulação, distribuição e consumo." 47

Vale aqui uma ponderação, pois, enquanto ordem jurídica é construção locutiva que alcança significado de alusão à esfera do dever-ser, ordem econômica é expressão que se vincula tanto ao mundo do ser quanto ao do dever-ser, de modo que pode subentender “certo modo de produção" ou, ainda. "[...] parcela da ordem jurídica que institui determinada forma econômica." 48

Na visão de EROs Roberto GrAU, a ordem econômica é "[...] o conjunto de princípios de organização da vida econômica, consagrados no Direito Positivo [...]." Neste particular, é, em si, uma “[...] ordem jurídico-econômica [...]”, ou melhor, “[...] uma parcela ou porção da ordem jurídica do moderno Estado Social. " 49

Destarte, é na ordem econômica que se encontram os princípios fundamentais da ordenação macrojurídica da atividade econômica, que gravitam em torno dos regimes jurídicos da propriedade e do contrato.

De acordo com Modesto CARvalhosa, a ordem econômica marca o perfil da organização da vida econômica, condicionando juridicamente a atividade econômica aos fins políticos do Estado. ${ }^{50}$ É, portanto, a ordem econômica a negação, no campo econômico, da ordem natural existente no liberalismo.

Vale ressaltar que há uma proximidade enorme entre as ideias de ordem econômica e Constituição econômica - tema a ser tratado em item posterior -, sobretudo ao se observar, sob o ponto de vista material, que a ordem econômica não se esgota em dispositivos constitucionais. "A Constituição apenas traça o perfil da ordem econômica,

\footnotetext{
47 PRADO, Luiz Regis. Direito penal econômico: ordem econômica, relações de consumo, sistema financeiro, ordem tributária, sistema previdenciário. P. 28.

${ }^{48}$ OLIVEIRA JÚNIOR, Gonçalo Farias de. Ordem econômica e direito penal antitruste. P. 42.

${ }^{49}$ GRAU, Eros Roberto. Elementos de direito econômico. P. 43.

${ }^{50}$ CARVAlHOSA, Modesto. A ordem econômica na Constituição de 1969. P. 52.
} 
perfil esse que é preenchido no nível da legislação ordinária-primordialmente no âmbito das normas de Direito Econômico."

De fato, a Constituição Federal de 1988 prevê, em seu artigo 170, os princípios que norteiam a ordem econômica brasileira, determinando ainda que "[...] fundada na valorização do trabalho humano e na livre iniciativa, tem por fim assegurar a todos existência digna, conforme os ditames da justiça social."

As normas nucleares da ordem econômica exercem a função de princípios gerais de toda a ordem jurídica, buscando instalar um regime de democracia substancial por meio da atuação estatal na ordem econômica, com vistas exatamente à realização dessa justiça social. $^{52}$

Não se pode deixar de lembrar que estes princípios insculpidos na Constituição Federal representam a vontade do constituinte, razão pela qual devem subordinar toda e qualquer atuação estatal no campo econômico.

\subsubsection{Constituições econômicas}

No momento em que o assunto econômico se "juridiciza" em grau constitucional, isto é, assume sentido jurídico, tem-se a chamada Constituição Econômica. ${ }^{53}$

Assim, a presença de temas econômicos nas constituições - seja em artigos esparsos e isolados, seja em capítulos próprios dedicados unicamente ao assunto - já apresenta o que se denomina de Constituição Econômica. É a forma pela qual o jurídico interage com o econômico. Tanto isso procede que, para JoÃo BosCO LEOPOLDINO DA FONSECA, “[...] a Constituição Econômica se corporifica precisamente no modo pelo qual o Direito pretende relacionar-se com a Economia." 54

\footnotetext{
${ }^{51}$ GRAU, Eros Roberto. Elementos de direito econômico. P. 44.

${ }^{52}$ SILVA, José Afonso da. Curso de direito constitucional positivo. P. 752.

${ }^{53}$ SOUZA, Washington Peluso Abino de. Primeiras linhas de direito econômico. P. 209.

${ }^{54}$ FONSECA, João Bosco Leopoldino da. Direito econômico. P. 50.
} 
Habitualmente, essa temática tem comparecido nos textos constitucionais em títulos e capítulos específicos intitulados "Ordem econômica e social”, "Ordem econômica", "Ordem econômica e financeira" etc. ${ }^{55}$

Em termos conceituais, é importante destacar que a Constituição Econômica pretende ver como pode o Direito conduzir o fenômeno econômico, devendo este ser considerado em sua substância para que se consiga uma adequação entre a norma e o fato. ${ }^{56}$ Inevitável, portanto, que haja a prévia consideração da realidade econômica da época para que possa surgir a norma jurídica direcionadora do fenômeno econômico.

Assim, a Constituição Econômica opera a conversão do regime econômico em ordem jurídico-econômica e tem por finalidade estabelecer os princípios e regras, informadores das normas que regerão as relações econômicas. ${ }^{57}$

Historicamente, é somente a partir da Primeira Guerra Mundial que o conceito de Constituição Econômica se intensifica, sendo ainda mais desenvolvido a partir da crise do capitalismo em 1929 e, posteriormente, com a Segunda Guerra Mundial.

O período em que surgiu esse conceito foi de todo adequado, pois, como explica VITAL MOREIRA,

“[...] a idéia de constituição econômica tinha precisamente por fim efetivar esses objetivos de reordenação econômica, através, desde logo, do estabelecimento de uma constituição jurídica da economia. Tal como a idéia de constituição começou por ser uma idéia de luta no princípio do século 19 , também agora a idéia de constituição econômica se apresentava como Kampfbegriff. Tal como na idéia de constituição se continha a representação de uma nova sociedade e de um novo estado, contra a realidade do ancien regime também agora na idéia de constituição econômica se continha a negação da ordem econômica liberal a favor da representação de uma nova ordem econômica. ${ }^{58}$

Nesse contexto, a Constituição Econômica foi assim definida pelo autor:

\footnotetext{
${ }^{55}$ SOUZA, Washington Albino Peluso de. Primeiras linhas de direito econômico. P. 207.

${ }^{56}$ FONSECA, João Bosco Leopoldino da. Direito econômico. P. 51.

${ }^{57}$ Idem, ibidem, p. 93.

${ }^{58}$ MOREIRA, Vital. Economia e constituição. Pp. 21/22.
} 


\begin{abstract}
"O conjunto de preceitos e instituições jurídicas que, garantindo os elementos definidores de um determinado sistema econômico, instituem uma determinada forma de organização e funcionamento da economia e constituem, por isso mesmo, uma determinada ordem econômica; ou de um determinado sistema e forma econômicos, que garantem e (ou) instauram, realizam uma determinada ordem econômica concreta." 59
\end{abstract}

Sua evolução é notada, sobretudo, a partir das Constituições que se inspiraram nas Cartas Mexicana de 1917 e de Weimar de 1919 e, com mais frequência, naquelas que sucederam a Segunda Guerra Mundial.

Na ordem jurídica, sua importância é diretamente sentida, posto que seus efeitos próximos ou remotos traduzem-se na legislação ordinária. Aliás, a atividade econômica em si gera a fértil produção legislativa que busca atendê-la. ${ }^{60}$ Para melhor compreensão do tema, merecem especial atenção as precursoras Constituições Mexicana e de Weimar.

A Mexicana destaca-se por ter sido o primeiro diploma constitucional a disciplinar sistematicamente a ordem econômica. Mas esse resultado não foi à toa, pois derivou de uma situação muito particular. Seguramente, no México, a Revolução de 1910 buscava solucionar problemas decorrentes do modelo de colonização adotado e da estrutura de exploração econômica até então vigente naquele país. Por este motivo, diversos artigos desta Constituição traziam disposições referentes à ordem econômica com mudanças radicais para o país e com profundos traços programáticos. Dentre as questões mais importantes tratadas nesta Constituição encontram-se: a divisão de terras, a exploração de recursos naturais e, de forma pioneira, o reconhecimento de uma série de direitos trabalhistas.

Já a Carta de Weimar era típica do Estado de Direito burguês, porquanto estabelecia um pacto social e assegurava certos direitos. Quanto às disposições sobre a ordem econômico-social, inovou o que a assemelhava à Constituição Mexicana, destacando-se pelo fato de dedicar todo um capítulo à matéria econômica com acentuadas características de intervencionismo econômico estatal. ${ }^{61}$

\footnotetext{
${ }^{59}$ Idem, ibidem, p. 41.

${ }^{60}$ SOUZA, Washington Peluso Albino de. Primeiras linhas de direito econômico. P. 210.

${ }^{61}$ SILVA, Américo Luís Martins da. A ordem constitucional econômica. Pp. 19.
} 
Não obstante tenha a Constituição de Weimar tratado de forma inovadora diversos aspectos da economia, as consequências da Primeira Guerra Mundial e a Grande Depressão de 1929 provocaram uma verdadeira crise na sociedade alemã, restando evidente que uma Constituição bem elaborada não é suficiente para garantir o sucesso econômico de um Estado.

Já no Brasil, ao disciplinar sobre a ordem econômica, as Constituições sempre tenderam a seguir o modelo liberal, notadamente, as Constituições do Império e a de 1891, que consagraram os princípios fundamentais do liberalismo.

A primeira delas buscou sua fonte de inspiração na Revolução Francesa e a sua tônica liberal foi, ainda, mantida na Constituição de 1891. Nesta última, já há disposições relativas ao tratamento da moeda e do comércio exterior. Se, por um lado, esta Constituição cuidou de matérias importantes como as mencionadas acima, por outro ignorou por completo preocupações fundamentais do fim do século XIX, tais como os problemas expressos no surgimento da chamada questão social, de repartição do produzido, e aqueles referentes à imperfeição da concorrência, que já eram alvo de normatização no exterior. ${ }^{62}$

Uma alteração nesse quadro é provocada apenas com a reforma constitucional de 1926 e, em seguida, com a ação política do Governo federal, a partir da Revolução de 1930. Assim, começam a surgir normas trabalhistas e previdenciárias, especialmente no período entre 1930 e 1934.

Nesse aspecto, é promulgada a Constituição de 1934, marcando o rompimento da ordem jurídica com a ideologia do liberalismo radical. Contrariamente às Constituições anteriores, que consagravam suas disposições relativas à matéria econômica nos capítulos dos "Direitos e garantias individuais”, a novel Carta trouxe capítulo específico intitulado "Ordem econômica e social”.

Ademais, sob a inspiração das Constituições Mexicana e de Weimar, foram previstos princípios fundamentais relativos ao Direito do Trabalho e ao Direito Previdenciário.

\footnotetext{
${ }^{62}$ GRAU, Eros Roberto. Elementos de direito econômico. Pp. 49.
} 
Ainda assim, a Constituição de 1934 foi um verdadeiro produto do liberalismo econômico, por isso, determinou como princípios da ordem econômica a justiça e necessidade da vida nacional, valores ínsitos àquela ideologia, ainda que nada tivesse disposto sobre o tema concorrencial e em matéria de desenvolvimento econômico.

Já a Constituição de 1937 destacou-se por introduzir dispositivo que se referia a questões concorrenciais, porém nada de relevante acrescentou à temática da ordenação econômica. De acordo com Eros GRAU, “[...] seu texto é marcado pelo autoritarismo do setor público e nele se incluem tão somente inovações de cunho político." 63

É de se ressaltar a acertada decisão de destinar capítulo próprio à ordem econômica, deixando de incorrer no equívoco semântico de confundir o social com o econômico.

A Constituição de 1946 trouxe como princípios fundamentais da ordem econômica a justiça social, a liberdade de iniciativa e a valorização do trabalho humano, mas nada definiu a respeito do desenvolvimento econômico. Inovou ao introduzir a disciplina da concorrência mediante a repressão aos abusos do poder econômico e por dispor sobre o princípio da função social da propriedade, ainda que de maneira embrionária.

A Constituição de 1967/1969, elaborada com base na ideologia da segurança nacional, adotou como princípio fundamental da ordem econômica a justiça social, trazendo, ainda, outros seis princípios. Surgiu, então, pela primeira vez, o princípio do desenvolvimento econômico como valor da ordem econômica.

Com base nos princípios trazidos por esse novo diploma constitucional, o Estado passou a assumir a responsabilidade de promover o desenvolvimento nacional, quer atuando no domínio econômico, quer intervindo indiretamente.

Já a Constituição Federal de 1988 foi marcada pela contraposição, nos campos econômico e social, aos fundamentos informadores do constitucionalismo anterior, eis que o rompimento com o período político antecedente propiciou a formação de uma nova ideologia. $^{64}$

${ }^{63}$ Idem, ibidem, p. 51.

${ }^{64}$ FONSECA, João Bosco Leopoldino da. Direito econômico. P. 123. 
No artigo 170 da Carta Constitucional, o constituinte assim evidenciou seus posicionamentos político e ideológico no que diz respeito ao papel do Estado na Economia: “[...] a ordem econômica, fundada na valorização do trabalho humano e na livre iniciativa, tem por fim assegurar a todos existência digna, conforme os ditames da justiça social."

No entender de Miguel Reale, adotou-se um posicionamento intermediário entre o liberalismo predominante no século XIX, que repele qualquer tipo de intervenção estatal, e o dirigismo do Estado. ${ }^{65}$ Trata-se de um regime neoliberalista ou social, cuja natureza é fundamentalmente capitalista, colocando-se a iniciativa privada como princípio básico desse sistema.

Não é demais ressaltar que o exercício desta liberdade de iniciativa deve reger-se pelos demais princípios constitucionais que norteiam a atividade econômica, notadamente, a livre concorrência, a outra face dessa mesma moeda.

\subsection{Livre Concorrência}

Pela Constituição de 1988, ela é elevada à condição de princípio - mais especificamente dentre os princípios da ordem econômica - contemplada no artigo 170, inciso IV.

Segundo EROS RoBERTO GRAU, a afirmação principiológica da livre concorrência no texto constitucional é, no mínimo, instigante, dado que ela, e não a liberdade de concorrência, somente poderia fixar-se em condições de mercado nas quais não se manifestasse o fenômeno do poder econômico. Este poder é inerente à nossa realidade e reconhecido pela nossa Carta Magna. Ao considerar essa legitimação, soa estranha a consagração principiológica da livre concorrência. ${ }^{66}$

Sob outro aspecto, o princípio igualmente se sobressai, visto que o próprio texto constitucional fartamente o confronta. A livre concorrência, obrigatoriamente, supõe uma desigualdade ao final da competição, a partir de um quadro de igualdade jurídico-formal, a

\footnotetext{
${ }^{65}$ REALE, Miguel. Aplicações da constituição de 1988. P. 132.

${ }^{66}$ GRAU, Eros Roberto. A ordem econômica na Constituição de 1988: interpretação e crítica. Pp. 210.
} 
qual é reiteradamente repelida ao longo da Constituição (artigo 170, inciso IX, artigo 179 e $\S \S 1^{\circ}$ e $2^{\circ}$ do artigo 171$) .{ }^{67}$

Ocorre que a interpretação do princípio da livre concorrência é outro que não aquele lido no preceito sob a óptica do liberalismo econômico. Não há oposição entre o princípio da livre concorrência e aquele que se oculta sob a norma do $\S 4^{\circ}$, do artigo 173 da Constituição Federal (princípio da repressão aos abusos do poder econômico), pois dele é fragmento. Este último inegavelmente compõe-se no primeiro.

Assim, livre concorrência significa liberdade de concorrência, desmembrada em liberdades privadas e pública, não soando, desse modo, estranha sua inserção dentre os princípios constitucionais. $^{68}$

Nos dizeres de TÉRCIO SAMPAIO FERRAZ JÚNIOR,

\begin{abstract}
"A livre concorrência de que fala a atual Constituição como um dos princípios da ordem econômica (art. 170, IV) não é a do mercado concorrencial oitocentista de estrutura atomística e fluida, isto é, exigência estrita de pluralidade de agentes e influência isolada e dominadora de um ou uns sobre os outros. Trata-se, modernamente, de um processo comportamental competitivo que admite gradações tanto de pluralidade quanto de fluidez. É este elemento comportamental, a competitividade - que define a livre concorrência. A competitividade exige, por sua vez, descentralização de coordenação como base da formação dos preços, o que supõe livre iniciativa e apropriação privada dos bens de produção. Neste sentido, a livre concorrência é forma de tutela do consumidor, na medida em que competitividade induz a uma distribuição de recursos a mais baixo preço. De um ponto de vista político, a livre concorrência é garantia de oportunidades iguais a todos os
\end{abstract}

${ }^{67}$ Idem, ibidem, p. 211.

${ }^{68}$ Quanto aos limites desse princípio, esclarecedor julgado do egrégio SUPREMO TRIBUNAL FEDERAL:

"[...] reduzir a defesa da liberdade de concorrência à defesa do concorrente, retrocedendo aos tempos da 'concepção privatística de concorrência' da qual é exemplo a 'famosa discussão sobre a liberdade de restabelecimento travada por Rui Barbosa e Carvalho de Mendonça no caso da Cia de Juta (Revista do STF (III), 2/187, 1914)', mas apenas de reconhecer que o fundamento para a coibição de práticas anticoncorrenciais reside na proteção a ambos os objetos da tutela: a lealdade e a existência de concorrência (...). Em primeiro lugar, é preciso garantir que a concorrência se desenvolva de forma leal, isto é, que sejam respeitadas as regras mínimas de comportamento entre os agentes econômicos. Dois são os objetivos dessas regras mínimas, (...) que o sucesso relativo das empresas no mercado dependa exclusivamente de sua eficiência, e não de sua 'esperteza negocial' - isto é, de sua capacidade de desviar consumidores de seus concorrentes sem que isso decorra de comparações baseadas exclusivamente em dados do mercado." (AC 1.657/MC, Rel. Min. Joaquim Barbosa, Tribunal Pleno, voto do Min. Cezar Peluso, DJ 31.08.2007). 
agentes, ou seja, é uma forma de desconcentração de poder. Por fim, de um ângulo social, a competitividade deve gerar extratos intermediários entre grandes e pequenos agentes econômicos, como garantia de uma sociedade mais equilibrada." ${ }^{69}$

É imperioso destacar que a livre concorrência não é apenas um direito subjetivo dos agentes econômicos, mas também um dever jurídico consistente em não se assumirem posturas anticoncorrenciais, sob pena de se sujeitarem à ação punitiva do Estado. Constatase que é a primeira vez que a liberdade de concorrência assume posição de princípio constitucional. Anteriormente, a livre concorrência era considerada como compreendida pela liberdade de iniciativa. ${ }^{70}$

Aliás, a menção a esse princípio informativo da ordem econômica significa adesão à economia, da qual é típica a competição, importando na igualdade dos processos concorrenciais, com a exclusão de práticas que privilegiem uns em detrimento de outros. ${ }^{71}$ Destaque-se que a livre concorrência foi “[...] elevada à condição de princípio da ordem econômica, na Constituição de 1988, mitigadamente, não como liberdade anárquica, porém social." 72

Na legislação brasileira, a livre concorrência e os princípios da liberdade de iniciativa, da função social da propriedade, da defesa dos consumidores e da repressão ao abuso do poder econômico concretizam-se mediante as regras da Lei $n^{\circ} 8.884 / 94,{ }^{73}$ tudo em absoluta coerência com a ideologia adotada pelo diploma constitucional de 1988.

\footnotetext{
${ }^{69}$ FERRAZ JÚNIOR, Tércio Sampaio. A economia e o controle do estado.

${ }^{70}$ OLIVEIRA JUNIOR, Gonçalo Farias de. Op. cit., p. 94.

${ }^{71}$ Idem, ibidem.

${ }^{72}$ GRAU, Eros Roberto. A ordem econômica na Constituição de 1988: interpretação e crítica. P. 214.

${ }^{73}$ Com a recente publicação da Lei no $12.529 / 11$, serão concretizadas pelos seus dispositivos.
} 


\title{
CAPÍTULO 2 A CONCORRÊNCIA
}

\subsection{Direito Concorrencial}

Primeiramente há que se observar que atualmente a denominação "Direito Concorrencial" é pouco utilizada, sendo mais comumente vista a expressão "Direito Antitruste", em razão da grande influência e inspiração do Direito norte-americano na legislação nacional sobre o tema. ${ }^{74}$ Todavia, a despeito de sua alta popularidade, esta última denominação não se mostra suficiente e própria do ponto de vista dos rigores técnico e científico. ${ }^{75}$ Preferível seria a expressão "Direito Concorrencial", porquanto diretamente relacionada com o objeto jurídico protegido por este ramo do Direito. Por este motivo, esse será o termo utilizado no presente trabalho.

Em um sentido mais amplo, o Direito Concorrencial pode ser entendido como “[... o conjunto de regras e instituições destinadas a apurar e a reprimir as diferentes formas de abuso de poder econômico e a promover a defesa da livre concorrência." 76

Para GeSner OliveIRA e JoÃo GRANDINO RodAs, este ramo do Direito consiste em um

\begin{abstract}
“[...] conjunto de regras jurídicas destinadas a apurar, reprimir e prevenir as várias modalidades de abuso do poder econômico, com o intuito de impedir a monopolização de mercados e favorecer a livre iniciativa, em favor da coletividade." ${ }^{, 77}$
\end{abstract}

Nesse prisma, alguns doutrinadores inserem o Direito Concorrencial na órbita do Direito Penal, definindo-o como “[...] o ramo do Direito Penal-Econômico que disciplina

\footnotetext{
${ }^{74}$ Nos Estados Unidos da América, o instrumento do trust era o mais utilizado para a concentração do Poder Econômico em poder de um só agente econômico e, por isso, o termo antitruste passou a ser utilizado no sentido de repressão às restrições concorrenciais e aos monopólios.

${ }^{75}$ FRANCESCHINI, José Inácio Gonzaga. Disciplina jurídica do abuso do poder econômico. P. 257.

${ }^{76}$ VAZ, Isabel. Direito econômico da concorrência. P. 242.

${ }^{77}$ OLIVEIRA, Gesner; RODAS, João Grandino. Direito e economia da concorrência. P. 29.
} 
as relações de mercado entre os agentes econômicos, tutelando-lhes sob sanção, o pleno exercício constitucional da livre concorrência em prol da coletividade nacional." 78

Em linhas gerais, pode-se afirmar que a legislação antitruste persegue quatro objetivos fundamentais, a saber:

\begin{abstract}
"O primeiro é o resguardo da liberdade individual, ao permitir a todo cidadão a escolha entre vários empresários concorrentes entre si para seus negócios ou profissão, evitando-se, desta forma, que parcela significativa do povo dependa, para suas atividades, da tolerância de grupos monopolísticos ou, mesmo, do Estado.

O segundo é a proteção do consumidor, no sentido de que os produtos sejam de boa qualidade e comercializados a preços compatíveis.

O terceiro é a contribuição para a maximização da eficiência econômica mediante decisões livremente tomadas pelos empresários.

O quarto é a melhor utilização da inventividade e da iniciativa individuais, pelo oferecimento a todos de maiores oportunidades de participação na atividade econômica do País." 79
\end{abstract}

A despeito de possuir variadas finalidades, pode-se assegurar que o Direito Concorrencial protege um único objeto jurídico, qual seja, o direito constitucional da livre concorrência. Nas palavras de JosÉ InÁCIO GONZAGA FRANCESCHINI,
“[...] não tem ele por finalidade amparar a política econômica do Estado ou seus interesses frente aos administrados e servidores, razão pela qual, inclusive, na taxinomia da lei, não se poderia localizá-lo nem no âmbito do Direito Administrativo, nem no do Direito Econômico." 80

Como é cediço, o Estado não é titular da livre concorrência e, menos ainda, da livre iniciativa. A liberdade de concorrer é direito conquistado dos agentes econômicos, coletivamente considerados para exercê-lo somente em favor da comunidade.

\footnotetext{
${ }^{78}$ FRANCESCHINI, José Ignácio Gonzaga. Disciplina jurídica do abuso do poder econômico. P. 257.

${ }^{79}$ Idem, ibidem, p. 255.

${ }^{80}$ Idem, ibidem, p. 260.
} 
Em vista disso, deve-se ter em mente que o Direito Concorrencial não tem o fim primordial de proteção da concorrência, no sentido de proteção da intervenção estatal em um regime onde o mercado se autorregula. $\mathrm{O}$ direito não é da concorrência e, menos ainda, pertence aos concorrentes, aos agentes econômicos. A única titular do bem protegido pelas normas concorrenciais é a coletividade.

Não é demais ressaltar que o valor central do Direito Concorrencial é a garantia da efetiva concorrência, e não de mercado. Para atingir este objetivo, o Estado deve, sim, agir dentro de determinados limites, auxiliando na tarefa de mitigar as imperfeições e falhas do mercado, sobretudo aquelas relacionadas à assimetria de informações, preservando a existência de concorrência. ${ }^{81}$

Outrossim, o Direito Concorrencial garante que o relacionamento entre os concorrentes se dê de forma leal, justa e equilibrada e que a concorrência efetivamente exista, sem a substituição por relações de poder, típicas de mercados livres.

É a concorrência e não o mercado o valor a ser protegido pelo Direito Concorrencial. A possibilidade de escolha representa um valor social que deve ser reconhecido pelo Direito. Já o mercado nem sempre conduz a esse resultado; portanto, torna-se necessária a intervenção do Estado, a fim de garantir a primeira e não o segundo. Só aquela é capaz de garantir o equilíbrio das relações econômicas. ${ }^{82}$

\subsubsection{Breve escorço histórico do direito concorrencial}

Para os objetivos do presente trabalho, é imprescindível a exposição da evolução histórica, ainda que breve, da disciplina da concorrência, a fim de que se compreendam os fundamentos do Direito Concorrencial da atualidade.

Desde a Antiguidade Grega já se observava certa disciplina da concorrência, mediante a regulamentação de monopólios, de forma a gerar consideráveis receitas ao Governo. Este último instituía monopólios estatais de pouca duração, em períodos de

${ }^{81}$ SALOMÃO FILHO, Calixto. Direito concorrencial: as condutas. P. 49.

${ }^{82}$ Idem, ibidem, pp. 48/49. 
dificuldade econômica, ao mesmo tempo em que mantinha leis para coibir abusos dos agentes econômicos, em prol do interesse da sociedade em geral.

Na Antiguidade Romana, era perceptível a prática dos monopólios, que assegurava intensa renda ao governo. Foi uma época de incentivo aos monopólios, que eram constantemente concedidos aos particulares. Em paralelo a essa prática, começaram a surgir preocupações concorrenciais, ainda que embrionárias. ${ }^{83}$ Assim, com o Édito de Zenão, criou-se uma regulamentação a esta política de monopólios, que visava, de algum modo, tutelar a população, reprimindo o abuso econômico. ${ }^{84}$

Os monopólios persistiram na Idade Média. Nas cidades mais desenvolvidas, ao lado dos monopólios estatais, surgem privilégios exercidos pelos agentes econômicos privados, que assumem aspectos característicos das grandes concentrações capitalistas contemporâneas.

O que torna este período rico em termos de história da disciplina da concorrência são as corporações de ofício, verdadeiras associações entre os agentes econômicos em vista da proteção de interesses comuns, assemelhadas, certamente, aos cartéis dos dias de hoje. Elas possuíam regras e estatutos editados pelos próprios artesãos para organizar suas atividades, com a finalidade de planejá-las e neutralizar, na medida do possível, a concorrência entre eles.

Em decorrência disto, nascem algumas regras de controle da atividade das corporações, no interesse do próprio consumidor. Tal como hodiernamente, àquela época houve reações contra os "cartéis" e os monopólios estabelecidos pelas corporações.

Por sua vez, o Mercantilismo trouxe um sistema de exclusividade no relacionamento comercial com as colônias, gerando um monopólio da compra e venda de seus produtos. O poder de concedê-los ou exclusividade de exploração de determinado setor da economia constitui mais um instrumento de poder nas mãos do soberano europeu. Esse o quadro, iniciou-se, no final do século XVI, a contestação da legalidade da concessão real desses monopólios - marco da história antitruste para os norte-americanos, pelas inúmeras decisões dos tribunais ingleses a respeito dessa questão, que culminou com

\footnotetext{
${ }^{83}$ MORAES, Bernardo Bissoto Queiroz de. Monopólio e acordos de não concorrência na Antiguidade. P. 10.

${ }^{84}$ FORGIONI, Paula A. Os fundamentos do antitruste. Pp. 35/36.
} 
a aprovação pelo Parlamento inglês do Statute of Monopolies, em 1624, impedindo a concessão real de monopólios.

Em um segundo período da história da concorrência, que se enquadra no momento em que eclodiu a Revolução Industrial, houve uma profunda modificação do sistema de produção, deixando a oficina do maestro de ser o centro produtivo para deslocar-se para as fábricas, onde surge a relação empregado-empregador. Com as ideias iluministas, a intervenção estatal cede espaço para o liberalismo, que traz consigo as leis naturais do mercado.

Nesse outro momento histórico, as antigas condutas de mercado perdem sentido, sendo preciso o restabelecimento da concorrência, com a consequente abolição das normas das corporações de ofício. Há exigência de uma liberdade maior de atuação para a busca de novos mercados, com a livre prática de preços; surge um mercado liberal, que traz correlata a ideia de livre concorrência.

Em sua obra A riqueza das nações (1776), ADAM SMITH elabora modelo teórico para o desenvolvimento científico da economia do século XVIII. O autor traz uma ideia central que critica as excessivas interferências e restrições do Governo sobre a economia, demonstrando que estruturas regradas atrapalham o crescimento. Ele leciona que o mercado, aparentemente caótico, é, na realidade, organizado naturalmente. ADAM SMITH esclarece que todo indivíduo, ao buscar seu interesse particular, promoverá, por via de consequência, o interesse da coletividade, pois

\footnotetext{
“[...] todo indivíduo não pensa senão no próprio ganho, e neste, como em muitos outros casos, é levado por uma mão invisível a promover um fim que não era, em absoluto, sua intenção. (...) Ao buscar seu interesse particular, não raro promove o interesse da sociedade de modo mais eficaz do que faria se realmente prestasse a promovê-lo." 85
}

Marcante para a história da concorrência, referido conceito de mão invisível baseou-se na expressão laissez faire, laissez passer, ideologia econômica oriunda do liberalismo que defendia a existência de mercado livre no comércio internacional, opondo-

${ }^{85} \mathrm{SMITH}$, Adam. A riqueza das nações. P. 567. 
se ao protecionismo do mercantilismo. Por meio deste conceito, sedimentou-se a ideia segundo a qual a economia funciona melhor quando há competição, resultando em produtos melhores e preços menores.

Como bem nos lembra ERos Roberto GraU, ${ }^{86}$ desde o princípio a liberdade econômica não é vista como um direito ilimitado dos comerciantes. O próprio ADAM SMITH reconhecia que algumas restrições estatais sobre a economia eram de suma importância. ${ }^{87}$ Ciente, já naquela época, dos abusos praticados por muitas empresas privadas, antecipando as preocupações mundiais atuais, chegou a denunciar as formações de monopólios e as conspirações comerciais geradoras de cartéis por estar preocupado com que esses fenômenos prejudicassem o trabalho da chamada mão invisível.

Assim, pode-se constatar que havia certa restrição por parte do Estado, objetivando o atendimento do interesse público, garantindo a manutenção do novo sistema que se instalava, lastreado na liberdade de atuar e concorrer. A partir de então, a concorrência passa a ser vista como a solução para conciliar a liberdade econômica individual com o interesse público.

Ao ser consagrado este segundo período da história da concorrência, surgiu em 1890 nos Estados Unidos da América o Sherman Act, ponto de partida, para muitos, do estudo dos problemas jurídicos relacionados à disciplina do poder econômico. Essa legislação constitui o mais significativo diploma legal que sedimentou a reação contra a concentração do poder nas mãos de alguns agentes econômicos, visando corrigir as distorções criadas pelo próprio sistema liberal. Até o fim deste período, a concorrência era vista como primordial para o sistema econômico, ao mesmo tempo em que se percebeu a necessidade de uma atuação do Estado para eliminar as distorções que pode causar ao sistema.

Em um terceiro período, com início no primeiro quarto do século $\mathrm{XX}$, alguns acontecimentos modificaram a postura do Estado em face da regulamentação da economia. Diante das crises do capitalismo, o Estado passa a dirigir o sistema, com o escopo de evitálas, aumentando sensivelmente as normas emanadas pelo Estado. Tal atuação transmuta-se

${ }^{86}$ Cf. GRAU, Eros Roberto. A ordem econômica na Constituição de 1988: interpretação e crítica. P. 225.

${ }^{87}$ Cf. SMITH, Adam. A riqueza das nações. P. 165. 
em disciplina jurídica da atividade privada, com a implementação de políticas públicas, identificando-se o nascimento do Direito Econômico, como ramo do Direito. ${ }^{88}$

Neste período é que surge o denominado Welfare State e pululam pelos países as Constituições Econômicas e Sociais. Os governos começam a intervir de forma proativa para evitar as crises e não apenas coibi-las.

O Estado passa, então, a atuar no domínio econômico, desempenhando diretamente funções que não tenham despertado o interesse dos empresários ou, ainda que por razões de interesse nacional, estimulem a participação do Governo. Isso sem prejuízo de sua atuação sobre o domínio econômico, como escopo de regular o processo de produção, por meio da atividade legislativa. É a chamada intervenção estatal, que, na maioria das vezes, é reconhecida pela utilização de norma destinada a tutelar a livre concorrência entre os agentes ou reprimir o abuso do poder econômico, ou seja, uma norma concorrencial ou antitruste.

Desta maneira, pouco a pouco a disciplina da concorrência passou a inserir-se em um contexto de dupla instrumentalidade, que,

\footnotetext{
"[...] por um lado organiza os processos que fluem segundo as regras da economia de mercado, colocando a sua disposição normas e instituições (...) e por outro, converte-se em um instrumento que lança mão o Estado para influir em tais processos e, a um tempo só, obter a consecução de determinados objetivos de política social - instrumento destinado ao desenvolvimento de políticas públicas [...]" 89
}

Sob esse contexto mundial, tornou-se cada vez mais evidente no Brasil a necessidade de se criar um rígido sistema de defesa da concorrência. Não à toa, a legislação brasileira que tutela a livre concorrência e regulamenta o combate ao abuso do poder econômico vem se fortalecendo ao longo dos anos, seja no âmbito administrativo, seja no penal.

${ }^{88}$ COMPARATO, Fabio Konder. Op. cit., p. 465.

${ }^{89}$ GRAU, Eros Roberto. A ordem econômica na Constituição de 1988. P. 33. 


\subsubsection{Direito concorrencial brasileiro}

Durante o colonialismo brasileiro, havia uma presença muito forte e marcante de uma política eminentemente fiscalista por parte da metrópole, representada pelos monopólios estatais que tinham como propósito principal a obtenção de lucros cada vez maiores na exploração da colônia. Não interessavam os progressos econômico e cultural da colônia, nem havia qualquer concorrência significativa estabelecida entre os agentes econômicos. Era forte o intervencionismo e inexistente qualquer tipo de concorrência.

Em alguns breves períodos posteriores, é notável um discreto desenvolvimento econômico. As chamadas Companhias lideravam o mercado, todavia alguns setores da população insurgiam-se contra seus privilégios e benefícios. ${ }^{90}$

Com a chegada de D. João VI no Brasil, introduziu-se uma política que acabou por fomentar o desenvolvimento econômico. Foi parcialmente desativada a política fiscalista e aberto grande espaço para o incentivo à economia. Funda-se o Banco do Brasil e se institui a liberdade de manufatura e indústria, ${ }^{91}$ criando-se, assim, um liberalismo pragmático relativo, exercido apenas em consonância com os interesses nacionais.

No período regencial e no segundo reinado, os representantes da pequena burguesia urbana não obtiveram sucesso em impor suas ideias liberais ao imperador. A classe agrária fortalecia-se no poder, assegurando muitos benefícios e privilégios. O mercado brasileiro era abastecido por mercadorias estrangeiras, sem incentivo algum à indústria interna, fato este que tornava ausente qualquer mínima tentativa de concorrência. ${ }^{92}$

Com a Carta Constitucional de 1934, eleva-se a liberdade econômica a status constitucional: "A ordem econômica deve ser organizada conforme os princípios da justiça e as necessidades da vida nacional, de modo que possibilite a todos existência digna. Dentro desses limites, é garantida a liberdade econômica" (artigo 115). Há liberdade, mas bem delimitada.

Já a Constituição de 1937, com inspiração nitidamente fascista, apresenta um novo contexto, no qual a intervenção estatal aparece como imposição do momento diante da

\footnotetext{
${ }^{90}$ FORGIONI, Paula A. Op. cit., p. 98.

${ }^{91}$ LIMA, Heitor Ferreira. História político-econômica e industrial do Brasil. P. 115.

${ }^{92}$ FORGIONI, Paula A. Op. cit., p. 107.
} 
falta de iniciativa particular, com intensa preocupação repressiva. O Estado busca suprir a atividade econômica privada (artigo 135).

Naquele mesmo diploma, inseria-se como princípio a proteção à economia popular (artigo 141). Assim, para regulamentá-la, promulga-se o Decreto-lei no 869 de 1938, primeiro diploma brasileiro concorrencial. Era visível que a evolução da disciplina da concorrência no Brasil não se deu como nos países com uma certa tradição antitruste. Nas palavras de PAUlA A. Forgioni,

“[...] o antitruste não nasce, no Brasil, como elo lógico de ligação entre o liberalismo econômico e (manutenção da) liberdade de concorrência. Nasce como repressão ao abuso do poder econômico e tendo como interesse constitucionalmente protegido o interesse da população, do consumidor." 93

Entretanto, tendo em vista que o aspecto antitruste do Decreto-lei no 869/38 acabou não se materializando, muitos autores consideram que o primeiro diploma legal de repressão ao abuso do poder econômico no País foi o Decreto-lei $\mathrm{n}^{\circ}$ 7.666/45, conhecido como Lei Malaia, destinado a coibir os atos contrários à ordem moral econômica. Se antes não havia qualquer sistematização das leis que cuidavam da repressão ao abuso do poder econômico, a Lei Malaia, que possuía caráter nitidamente administrativo, disciplinava o assunto de maneira sistemática. ${ }^{94}$

De maior relevância para a disciplina da concorrência são os dispositivos da Constituição brasileira de 1946, eis que elaborados sob a influência da intensa repercussão do Decreto-lei $n^{\circ} 7.666 / 45$, embora ele nunca tenha sido efetivamente utilizado. Esses trouxeram, pela primeira vez, de forma expressa, o princípio de repressão ao abuso do poder econômico (artigo 148).

Outro diploma que merece destaque é a Lei $\mathrm{n}^{\circ} 1.521$, de 26 de dezembro de 1951, que, apesar de alterar artigos da legislação vigente sobre crimes contra a economia popular, trouxe dispositivos tipicamente antitruste. Não abordou, no entanto, a repressão ao abuso do poder econômico, tema que recebeu regulamentação apenas com a promulgação da Lei $n^{\circ} 4.137 / 62$, que instituiu o CADE.

${ }^{93}$ Idem, ibidem, p. 114.

${ }^{94}$ MUNHOZ, Carolina Pancotto Bohrer. Direito, livre concorrência e desenvolvimento. Pp. 172/173. 
As Constituições de 1967 (artigo 157, VI) e de 1969 (artigo 160, V) mantiveram a repressão ao abuso do poder econômico como princípio constitucional, inserido no título da Ordem Econômica e Social. A Lei n ${ }^{\circ} 4.137 / 62$ foi recepcionada por ambas as Constituições e manteve a sua vigência.

Esta Lei trouxe para a repressão do abuso de poder econômico instrumentos de sanção a posteriori, de natureza penal-administrativa, e instrumentos a priori, de natureza eminentemente civil.

Com o advento da Constituição de 1988, a livre concorrência é eleita como um dos princípios da ordem econômica (artigo 170, IV) e, em seu artigo 173, § $4^{\circ}$ determina-se que “[...] a lei reprimirá o abuso do poder econômico que vise à dominação dos mercados, à eliminação da concorrência e ao aumento arbitrário dos lucros."

Nesse sentido, após as poucas mudanças advindas com a Lei $\mathrm{n}^{\circ}$ 8.158/91, é promulgada a Lei ${ }^{\circ}$ 8.884/94, que sistematiza a matéria antitruste no País, implementando o denominado "Sistema Brasileiro de Defesa da Concorrência” (SBDC).

Hodiernamente, o SBDC é composto pelo CADE, órgão judicante, formado por um Plenário e uma Procuradoria. Ele foi transformado em autarquia e criado com a finalidade de orientar, fiscalizar, prevenir e apurar abusos de poder econômico pela Secretaria de Acompanhamento Econômico (SEAE/MF) e pela Secretaria de Direito Econômico (SDE/MJ), cabendo a estas últimas instruir os atos de concentração e investigar possíveis ilícitos concorrenciais. ${ }^{95}$

Recentemente, foi determinada a revogação dos dispositivos da Lei $n^{\circ}$ 8.884/94 pela Lei ${ }^{\circ} 12.529 / 2011$ - publicada em 30 de novembro de 2011, mas ainda em período de vacatio legis por 180 dias -, que reformulou todo o sistema nacional de defesa da concorrência, de modo que, paulatinamente, serão implementadas as alterações estruturais necessárias para adequação aos ditames legais.

De acordo com as recentes inovações, o SBDC será formado apenas pelo CADE e pela SEAE/MF. ${ }^{96}$ A esta última competirá promover a concorrência em órgãos de governo

95 BRASIL. MINISTÉRIO DA JUSTIÇA. CADE. Estrutura do sistema brasileiro de defesa da concorrência.

${ }^{96}$ Artigo $3^{\circ}$, da Lei no $12.529 / 2011$. 
e perante a sociedade. O CADE será composto por três órgãos, cada qual com sua atribuição específica. São eles: o Tribunal Administrativo de Defesa Econômica, órgão de função judicante; a Superintendência-Geral, que será responsável pela instauração e instrução de inquéritos e procedimentos administrativos para apuração de infrações administrativas e de atos de concentração, dentre outras atribuições; o Departamento de Estudos Econômicos, incumbido de elaborar estudos e pareceres econômicos. ${ }^{97}$ Junto ao CADE funcionará, ainda, a Procuradoria Federal Especializada. ${ }^{98}$

\subsection{Concorrência como Objeto de Tutela do Estado}

Para que se possa analisar a questão referente à pertinência da escolha da concorrência como bem objeto de tutela penal do Estado, é fundamental que se relembre qual o interesse estatal em intervir no mercado para garantir o equilíbrio entre agentes econômicos.

O Direito Econômico, como se viu em capítulo anterior, aparece como a normatização pela qual se concretiza a política de intervencionismo no âmbito econômicosocial, de tal sorte que não se pode negar a preocupação do Estado com essa área.

A respeito de uma busca pela definição do interesse protegido pela legislação concorrencial, GESNER DE OLIVEIRA e JOÃO GRANDINO RODAS lecionam:

\footnotetext{
“À medida que as finalidades de otimizar a eficiência econômica e proteger o processo competitivo evoluíram através dos anos, o pensamento sobre quem seriam os beneficiários finais desses objetivos também mudaram. Assim como o Canadá, os Estados Unidos da América, inicialmente, estavam preocupados com a descentralização do poder econômico dentro de parâmetros justos e equitativos, levando-os a considerar como prioridade absoluta a proteção da pequena empresa. Entretanto, à medida que o bem estar do consumidor e da sociedade como um todo foram erigidos ao status de beneficiário principal da concorrência, entraram em conflito as prioridades de maximizar a proteção do consumidor. Ficou claro que, frequentemente, objetivos não econômicos, tais como a equidade e a proteção de pequenos negócios, podiam ser vistos como
}

\footnotetext{
${ }^{97}$ Artigo $5^{\circ}$, da Lei $\mathrm{n}^{\circ} 12.529 / 2011$.

${ }^{98}$ Artigo 15, da Lei $\mathrm{n}^{\circ} 12.529 / 2011$.
} 
arbitrários e imprevisíveis, capazes de distorcer o processo competitivo e dificultar decisões empresariais. Proteger a 'concorrência' e não os concorrentes tornou-se o dogma fundamental da política da concorrência através dos anos." 99

\title{
CAROLINA PANCOTTO BOHRER MunHOZ observa:
}

\begin{abstract}
“Ao analisar o modelo brasileiro, verifica-se que, tanto a Constituição de 1988, como a legislação em vigor, adotaram o critério de proteção da pluralidade de interesses envolvidos na concorrência, e não apenas o interesse do consumidor. O parágrafo único do artigo $1^{\circ}$ da Lei $n^{\circ} 8.884 / 94$ é claro ao afirmar que a coletividade é a titular dos bens jurídicos protegidos por aquela lei. Na medida em que o direito concorrencial afeta os interesses de todos os participantes do mercado entre os titulares dos direitos subjetivos decorrentes da defesa da concorrência.
\end{abstract}

Entre os bens jurídicos mais importantes protegidos pela concorrência estão o direito de competir e a liberdade de escolher, além da garantia da possibilidade de efetiva competição. Ao proteger esta pluralidade de interesses, o legislador optou por estender a garantia da liberdade de escolha para todos os agentes de mercado, não apenas os consumidores, mas também os produtores. A liberdade de escolha representa um valor em si mesmo, e na perspectiva do desenvolvimento como processo de expansão de liberdade, é de suma importância proporcionar aos agentes - todos os agentes - a liberdade de escolher e a de competir. Esta importância deriva não apenas do aspecto econômico das mesmas, mas também em função de seus efeitos sobre as demais liberdades que compõem o processo de desenvolvimento." 100

Esta pluralidade de interesses da legislação antitruste é claramente encampada pelo constituinte e pelo legislador brasileiro. O artigo 170 da Carta Magna prevê como princípios gerais da ordem econômica a livre concorrência e a defesa do consumidor (incisos IV e V). Igualmente, a Lei n ${ }^{\circ} 8.884 / 94$ orienta-se pela liberdade de iniciativa, livre concorrência, função social da propriedade, defesa dos consumidores e repressão do abuso do poder econômico. Na mesma linha, apresenta-se a recém-aprovada Lei nº 12.529/11.

\footnotetext{
${ }^{99}$ OLIVEIRA, Gesner; RODAS, João Grandino. Direito e economia da concorrência. P. 08.

${ }^{100}$ MUNHOZ, Carolina Pancotto Bohrer. Direito, livre concorrência e desenvolvimento. Pp. 195/196.
} 
Ao seguir essa mesma linha de raciocínio, CALiXto SAlomão FilHo aduz que podem ser identificados três interesses protegidos pelas normas de concorrência, quais sejam: o interesse institucional da ordem concorrencial, o dos consumidores e o dos participantes do mercado, isto é, os próprios concorrentes. ${ }^{101}$ É sobre eles que se passará a tratar a partir de agora.

\subsubsection{Interesse da ordem concorrencial}

Para que se proceda à análise da ordem concorrencial como interesse tutelado pelo Direito Concorrencial, é essencial considerar que, indubitavelmente, ela constitui um interesse institucional. Tal conclusão depreende-se diretamente do exame da legislação ordinária, pois o artigo 88 da Lei $n^{\circ} 8.884 / 94$ incluiu as infrações à ordem econômica entre os interesses tutelados por meio de ação civil pública, assim como previu que as associações destinadas à proteção da ordem econômica e da livre concorrência poderão proteger os referidos interesses. A novel Lei $\mathrm{n}^{\circ}$ 12.529/2011 manteve em seu artigo 117 disposição semelhante.

Além disso, a concorrência possui características muito próximas àquelas aplicáveis aos interesses institucionais, os quais, sem dúvida, são marcados pelo seu duplo grau de proteção, porquanto suas garantias se prestam tanto à proteção de cada indivíduo quanto de sua coletividade.

São interesses jurídico e economicamente distintos dos individuais, pois possuem meios de proteção especiais e, quando envolvidos na hipótese, se consegue identificar benefício direto à coletividade, que não se confunde com aqueles destinados a cada indivíduo.

Destarte, pode-se sustentar que a concorrência traduz um interesse institucional, protegendo garantias individuais (concorrentes e consumidores) e coletivas (ordem concorrencial) simultaneamente, sendo necessárias as suas regras para a manutenção de todo um sistema.

${ }^{101}$ SALOMÃO FILHO, Calixto. Direito concorrencial: as condutas. P. 61. 
Ao abordar esta variedade de interesses na proteção da concorrência, FABIO ULHOA COELHO atesta que a legislação antitruste objetiva tutelar diretamente a própria estruturação do mercado; só que, ao fazê-lo, acaba por refletir não apenas a respeito dos interesses dos empresários lesados pelas práticas anticoncorrenciais, mas sobre os interesses dos consumidores, trabalhadores e até da sociedade em geral. ${ }^{102}$

Logo, a proteção da concorrência aparece como instrumento de tutela de valores e interesses mais amplos que os meramente individuais, destinando-se à preservação de mecanismos de mercado, e não apenas dos interesses de seus figurantes.

\subsubsection{Interesse dos consumidores}

O segundo interesse tutelado pelo Direito Concorrencial é aquele dos consumidores. Ainda que pareça o mais óbvio de todos eles, a afirmação de sua existência tem apresentado uma série de equívocos que merecem ser devidamente esclarecidos.

Em uma primeira análise, pode parecer que os consumidores são os sujeitos exclusivos tutelados pela legislação antitruste, especialmente porque a própria teorização econômica do Direito da Concorrência baseia-se na proteção do consumidor, ${ }^{103}$ o qual, precisa ter à sua disposição uma possibilidade grande de escolha entre os produtos e serviços oferecidos no mercado; além do mais, ele tem de ter a garantia de boa qualidade dos mesmos e de preços justos, preocupações que merecem atenção da legislação concorrencial.

A respeito desse vínculo entre a defesa da concorrência e a tutela do consumidor, PAULA A. FORGIONI leciona

\footnotetext{
"Em sistemas nos quais tradicionalmente há a concentração de poder, com a presença de mercados cartelizados, costuma-se controlar a atividade dos agentes econômicos em posição dominante, impedindo que estes dela abusem em detrimento do consumidor. Não há um combate à posição dominante em si
}

\footnotetext{
${ }^{102}$ COELHO, Fabio Ulhoa. Direito antitruste brasileiro: comentários à Lei no 8.884/94. P. 05.

${ }^{103}$ SALOMÃO FILHO, Calixto. Direito concorrencial: as condutas. P. 81.
} 
e muito menos à concentração de empresas, impedindo-se, apenas, o abuso do poder econômico, o que pode implicar a repressão a lucros excessivos;" 104

Não por outro motivo, a Lei $n^{\circ} 8.884 / 94$ faz menção expressa, em variados momentos, à tutela do consumidor (a título de exemplo, tem-se os artigos $\left.1^{\circ}, 27,29,54\right) .{ }^{105}$

Porém, isto não significa que o bem-estar do consumidor deve ser o único interesse a guiar a política da concorrência. O fato de o consumidor ser o destinatário econômico final das normas concorrenciais não significa que ele seja o destinatário jurídico direto delas. Aliás, não raramente, o seu interesse acaba sendo protegido mediante a proteção da própria instituição concorrência. ${ }^{106}$

Em alguns casos, como na prática de preços predatórios, pode parecer que uma proteção direta aos interesses dos consumidores é até contrária aos interesses protegidos pelas normas concorrenciais, pois a conduta ilícita, no curto prazo, os beneficia.

Ademais, o reconhecimento de uma titularidade direta do consumidor em relação aos interesses protegidos pela lei concorrencial acarretaria em uma livre legitimidade para propor demandas protetivas de tais interesses, o que poderia resultar em um grande abuso, inclusive com o ingresso de ações com o fim exclusivo de prejudicar determinados concorrentes. $^{107}$

Vale lembrar que o interesse do consumidor, na realidade, "[...] consiste precipuamente na existência da concorrência" e "é mediado pela proteção da existência de concorrentes para ter de considerar a prática ilícita." 108

Por esse motivo, mesmo que excluído o controle das estruturas e os atos tendentes à dominação de mercado, restam casos em que o consumidor tem sim titularidade direta

\footnotetext{
${ }^{104}$ FORGIONI, Paula A. Op.cit., p. 237.

${ }^{105}$ Nesse sentido, cf. MARTINEZ, Ana Paula. A proteção dos consumidores pelas normas concorrenciais. Pp. 18/19. Também o faz a Lei ${ }^{\circ}$ 12.529/11.

${ }^{106}$ SALOMÃO FILHO, Calixto. Direito concorrencial: as condutas. P. 82. O autor aponta como exemplo a proteção contra atos tendentes à dominação do mercado (artigo 20, III, da Lei no 8.884/94). Neles apenas indiretamente o consumidor tem interesse.

${ }^{107}$ Por isso, ao ver de CALIXTO SALOMÃo FILHO, “Agiu bem, portanto, o legislador brasileiro ao limitar a possibilidade de propositura de ações individuais ou coletivas às infrações à ordem econômica, ou seja, apenas às hipóteses elencadas nos arts. 20 e 21 da lei concorrencial (controle dos comportamentos) ( $v$. arts. 29 e 88 da lei 8.884/94). No caso do controle das estruturas a via judicial continua aberta, mas apenas para o natural e constitucionalmente obrigatório controle judicial dos atos administrativos (decisão do CADE)." Direito concorrencial: as condutas. P. 82.

${ }^{108}$ SALOMÃO FILHO, Calixto. Direito concorrencial: as condutas. P. 82.
} 
sobre alguns direitos. Um grande exemplo é o grupo de atos de abuso do poder econômico, pois inegável haver aqui uma relação direta entre o agente que pratica o ilícito e o próprio consumidor. Entre os ilícitos de concorrência desleal, em que pese o fato de restar evidente a proteção institucional da concorrência, o consumidor será destinatário direto das normas sempre que puder caracterizar que é diretamente por meio dele que a concorrência desleal está se configurando.

Feitas essas ponderações, pode-se concluir que os consumidores não são destinatários diretos da legislação antitruste em todos os casos, ainda que sejam tutelados mediatamente por ela. De toda sorte, serão sempre sua justificação última.

\subsubsection{Interesse dos concorrentes}

Ao abordar o tema da concorrência como objeto de tutela do Estado, é lógico e automático pensar que o objetivo desta proteção é garantir certa igualdade entre os agentes econômicos, evitando que qualquer um deles adote medidas que restrinjam, ou mesmo eliminem, a participação dos demais no mercado.

Por um longo tempo, o Direito Concorrencial foi visto como um conjunto de regras éticas especificamente destinadas aos concorrentes, até porque é visível o prejuízo aos concorrentes provocado pelas práticas anticoncorrenciais.

Apesar de, em um primeiro momento, esses prejuízos serem sentidos pelos próprios agentes econômicos, que perderão significante parcela de sua participação no mercado, ou dele serão excluídos, em longo prazo todo o sistema concorrencial restará ameaçado.

Dessa maneira, é evidente que os interesses dos concorrentes também são tutelados pela proteção da ordem concorrencial. No entanto, a proteção direta e exclusiva entendida aqui como absolutamente dissociada do interesse institucional da concorrência destes interesses pelas normas concorrenciais deve ser evitada tanto na esfera abstrata quanto concreta. ${ }^{109}$

${ }^{109}$ SALOMÃO FILHO, Calixto. Direito concorrencial: as condutas. P. 92. 
A questão referente à esfera abstrata diz respeito à possibilidade de escolha de um determinado concorrente para a tutela do Direito Concorrencial. Logo de início, pode-se pensar na proteção dos agentes econômicos aparentemente mais frágeis, quais sejam, as pequenas e médias empresas.

Realmente, a Constituição Federal de 1988, em seu artigo 170, inciso IX, previu tratamento favorecido a essas empresas. No entanto, os benefícios concedidos não podem alcançar tal abrangência que tornem as empresas de pequeno porte absolutamente imunes às normas concorrenciais.

Tal possibilidade vai de encontro aos princípios e à própria essência do Direito Concorrencial, que não permite o privilégio a nenhum concorrente nem atribuição de vantagens adicionais. É inegável que as pequenas e médias empresas devem ser protegidas, mas como qualquer outro concorrente do mercado, preservando-se a igualdade de condições entre eles.

Aliás, especificamente com relação a essas empresas, cumpre destacar que elas já deixam de receber grande parte das sanções concorrenciais, porquanto as regras do Direito Concorrencial consideram o poder de mercado para exercer o controle e sancionar os agentes econômicos.

A par disso, também sobre o aspecto concreto, a tutela direta dos interesses dos concorrentes deve ser negada, pois esta ocorre quando se considera a possibilidade de caracterização do ilícito apenas com a lesão do interesse dos concorrentes, sem a presença do interesse institucional. ${ }^{110}$

Ora, a proteção exclusiva dos interesses dos concorrentes causaria danos a todo o mercado, pois prejudicaria a atuação daqueles agentes econômicos que desenvolvessem estruturas de produção mais eficientes, impedindo-os de conquistar licitamente maior participação no mercado e, do mesmo modo, privando os consumidores de se beneficiarem com a concorrência.

As práticas anticoncorrenciais puníveis tutelam mediatamente os interesses dos concorrentes, sempre trazendo consigo a proteção imediata aos interesses institucionais da concorrência.

${ }^{110}$ Idem, ibidem, p. 93. 
À guisa de exemplo, os atos tendentes à dominação de mercado acabam por proteger os interesses dos concorrentes, estes consubstanciados na proteção da instituição concorrência, que não permite essa concentração de poder.

De igual maneira, os interesses dos concorrentes estão presentes nos ilícitos de concorrência desleal. Apesar de aparentemente estas condutas dirigirem-se diretamente à tutela dos interesses dos concorrentes, a proteção de padrões mínimos de lealdade é fundamental para que a concorrência, como instituição, se mantenha.

Outrossim, estabelecidos os interesses da legislação antitruste, conclui-se que a presença do interesse institucional, único tutelado imediatamente pelas regras concorrenciais, permite a resolução de quaisquer conflitos que eventualmente possam surgir entre eles.

\subsection{Direito Penal Moderno: o Direito Penal Econômico}

O intervencionismo estatal, proveniente, sobretudo, das Constituições Econômicas, levou a produção, a circulação e a distribuição de riquezas a obedecer a uma ordem jurídica, culminando no surgimento do Direito Econômico moderno durante a Primeira Guerra Mundial. ${ }^{111}$

Este marco histórico, pelos conflitos sociais que o acompanharam e, sobretudo, pela necessidade de direção da economia para os esforços da guerra, levou o Estado a assumir o papel de responsável sobre a vida econômica, fato que contribuiu para uma repressão maior às condutas atentatórias à ordem econômica.

Com efeito, no final da segunda década do século passado, constatou-se uma tendência de criminalização, uma verdadeira inflação penal, consistente na emissão apressada, desordenada e, muitas vezes contraditória, de regras penais contra condutas abominadas pelo Direito Econômico.

Com a repressão de práticas atentatórias à ordem econômica surgiu um novo ramo do Direito Penal: o Direito Penal Econômico. Sua existência acaba por ser reconhecida

\footnotetext{
${ }^{111}$ OLIVEIRA, Gesner; RODAS, João Grandino. Direito e economia da concorrência. P. 337.
} 
ainda que não haja consenso com relação aos seus limites, objeto, denominação e mesmo dúvidas acerca da própria legitimidade de criminalizar. ${ }^{112} \mathrm{O}$ aparecimento deste ramo do direito tem sido marcado pelo imprevisto, pois se nota que, de modo geral, o Direito Penal Econômico alimenta-se das sequelas das crises econômicas ou dos conflitos bélicos. ${ }^{113}$

Por outro lado, é relevante destacar que cada Estado atribui ao Direito Penal Econômico as funções que entende convenientes, fato que lhe confere caráter nacional, mas, ao mesmo tempo, dificulta a delimitação do âmbito desse ramo jurídico. Na maioria das vezes, as suas normas não são compiladas em Códigos Penais, mas sim constituem leis esparsas, ficando à margem da consciência popular. ${ }^{114}$

Por essa razão, uma das tarefas mais complexas nessa seara reside na própria definição de Direito Penal Econômico. No Brasil, é comum incluírem neste ramo do Direito temas não afetos à área econômica e excluírem questões de extrema relevância e pertinência, tais como cartel, dumping etc., de maneira a restringir a temática econômica a infrações tributárias e previdenciárias. ${ }^{115}$

Ao tentar definir este ramo do Direito Penal, MANOEL PEDRo PIMENTEL aduz que é um "[...] conjunto de normas que tem por objeto sancionar, com as penas que lhe são próprias, as condutas que, no âmbito das relações econômicas, ofendam ou ponham em perigo bens ou interesses juridicamente relevantes". 116

Todavia, é pertinente a seguinte lição de EDUARDO REALE FERRARI:

\footnotetext{
“[...] vaga e lacunosa constitui tal definição, podendo em tal síntese atrelar-se a qualquer tema atinente à economia, motivo pelo qual parece-nos assistir razão a Miranda Gallino ao não conceituar propriamente Direito Penal Econômico, limitando-se a afirmar negativamente que o Direito Penal não protege ou tutela a realização do fenômeno econômico como fato em si, mas sim protege a integridade da ordem, que se estima necessário para o cumprimento desse fato, de modo que pode produzir-se os fins propostos,
}

\footnotetext{
${ }^{112}$ Idem, ibidem, p. 338.

${ }^{113}$ DIAS, Jorge de Figueiredo; ANDRADE, Manuel da Costa. Problemática geral das infracções contra a economia nacional. P. 68.

${ }^{114}$ OLIVEIRA, Gesner; RODAS, João Grandino. Direito e economia da concorrência. P. 338.

115 FERRARI, Eduardo Reale. Legislação penal antitruste: direito penal econômico e sua acepção constitucional. P. 588.

${ }^{116}$ Idem, ibidem, p. 10.
} 
ficando claro que qualquer conduta que produza a ruptura da ordem econômica pode trazer como conseqüência uma necessária sanção.” 117

\section{Para RAFAEl MiRAnda GaLlino, o delito econômico}

“[...] es la conducta punible que produce uma ruptura en el equilibrio que deve existir para el normal desarollo de las etapas del hecho económico; o bien, la conducta punible que atenta contra la integridad de las relaciones económicas públicas, privadas o mistas y que como consecuencia ocasiona daño al orden que rige la actividad económica y provoca una situación de la que puede surgir este daño." 118

\section{Acerca do tema, Miguel BAJo FernANDEZ ensina que}

“[...] el derecho penal económico es un grado de dicha intervención estatal. Precisamente el grado más intenso de intervención del Estado en la economia utilizando su poder sancionador. La finalidad y la función de Derecho penal económico no son outra cosa que la sublimación de la finalidad y la función del intervencionismo estatal en la economia: cumplir las exigências de una valoración diferente del imperativo de Justicia en orden a las relaciones sociales y economicas... En definitiva, el Derecho penal económico es el conjunto de normas penales que garantizan el orden económico." 119

\section{Já para RENÉ ARIEL DotTI, o Direito Penal Econômico}

\section{“[...] vem a ser um ramo específico do chamado direito econômico, enquanto} resguarda, através da pena criminal, os bens jurídicos de caráter

\footnotetext{
${ }^{117}$ Idem, ibidem, p. 589.

118 GALLINO, Rafael Miranda. Delitos contra el orden económico. P. 26. Em complemento a esta definição, GÉRSON PEREIRA DOS SANTOS assim se pronuncia: "[...] o delito econômico importa ao direito penal como instrumento da tutela da ordem jurídica econômica, a qual está, por assim dizer, inserida na ordem jurídica, lato sensu, que, por sua vez, não pode alhear-se do mundo circundante, não adstrito às excessivas preocupações racionalistas.” (Direito Penal Econômico, p. 103).

${ }^{119}$ BAJO FERNANDEZ, Miguel. El derecho penal económico: un estudio de derecho positivo español. P. 91.
} 
supraindividual ou social, distintos do patrimônio, embora possa alcançar o

interesse dos particulares, consumidores ou competidores." 120

Não obstante a ausência de univocidade no conceito de Direito Penal Econômico, pode-se dizer que a tutela penal na seara econômica vai ao encontro das políticas de repressão ao abuso do poder econômico, voltando-se os tipos penais às condutas desenvolvidas em atividades estritamente econômicas, em proteção direta à saúde da boa ordem econômica.

Trata-se, pois, de uma tutela supraindividual, ou seja, da proteção de um interesse difuso, não sendo facilmente revelado um determinado indivíduo diretamente lesado. A ordem econômica como um todo resulta lesada, isto é, há uma violação de um bem imaterial comum a todos os cidadãos, não sendo possível apontar quais indivíduos o detêm e quais serão diretamente prejudicados pela prática de uma conduta descrita em um tipo penal econômico. ${ }^{121}$

No que tange aos tipos penais, sua maioria apresenta grande dificuldade de compreensão, resultante do exagerado tecnicismo terminológico que os envolve. A instabilidade e a relatividade das normas econômicas, decorrentes das variáveis políticoeconômicas, dão ensejo a tipos penais altamente complexos, imprecisos e, por vezes, abertos em demasia.

Em virtude de os fatos econômicos acontecerem com intensa agilidade e serem obrigatoriamente acompanhados pelo Direito Penal Econômico, a abrangência e interpretação dos tipos penais deste ramo do Direito são modificadas de maneira constante e rápida. Ademais, não raramente, estes tipos penais repetem condutas já descritas como infrações administrativas, conquanto não ignorem a taxatividade exigida na seara penal, fato este que induz a uma elasticidade dos elementos normativos do tipo e a uma difícil compreensão de sua delimitação.

\footnotetext{
${ }^{120}$ DOTTI, René Ariel. A criminalidade econômica. P. 296.

${ }^{121}$ Nas palavras de RenAto De Mello JoRge Silveira, "O Direito Penal Econômico é claro exemplo também da proteção penal difusa. (...) Identifica-se o bem jurídico não só supra-individual, mas verdadeiramente intermediário, num claro exemplo da presença de interesse difuso a ser protegido. Entende-se, assim, como protegida a própria ordem socioeconômica.” (SILVEIRA, Renato de Mello Jorge. Direito penal supra-individual: interesses difusos. Pp. 144/145).
} 
De acordo com GESNER OliveIRA e JOÃo GRANDINo RodAS, as explicações para este fenômeno saltam aos olhos:

\begin{abstract}
"O Estado-salutista prefere desencorajar comportamentos contrários a certos interesses sociais por meio de recurso abusivo à repressão criminal do que recorrer, por exemplo, a uma política de informação ou assistência. Por essa razão, a quase totalidade de infrações que o Estado-polícia tinha como da competência exclusiva da Administração acabou sendo transformada em ilícito criminal, gerando anomia, desgastando os padrões ético-jurídicos e ferindo a própria dignidade do direito penal. Para Hassemer (1994, p. 41), tal estado de coisas é causado pelo medo da criminalidade moderna, que conduz o legislador a demonstrar preocupação e a reagir imediata e simbolicamente criando, muitas vezes, um direito penal também simbólico, mas ineficaz à luta efetiva e eficiente contra a criminalidade, aumentando as penas, por exemplo. Ele entende que a necessidade de combater a criminalidade moderna não pode fazer olvidar que o importante aspecto normativo, de proteção jurídica do direito penal." 122
\end{abstract}

É indiscutível o desenvolvimento de uma emergente criminalidade econômica, caracterizada por uma vitimização difusa, causadora de males imensuráveis à sociedade. Paralelamente e em decorrência disto, há um crescente avanço e modernização do Direito Penal Econômico quanto à criação de novos delitos econômicos e sua repressão.

Por certo, esses são os frutos de uma produção legislativa desenfreada. A intensa preocupação com o abuso do poder econômico provocada pela inflexão de uma economia globalizante e por um desconcertado "liberalismo econômico" fez eclodir uma reação desmesurada pela normatização penal no âmbito econômico.

Ocorre que este avanço e consequente inflação da legislação penal especial, muitas vezes, não reflete na melhor maneira de reprimir a criminalidade econômica, até pelas não raras vezes que esta repressão é obtida em atropelo à normatização administrativa e às custas da violação de princípios constitucionais penais.

É este o contexto em que se situam os chamados delitos concorrenciais, notadamente o crime de formação de cartel.

${ }^{122}$ OLIVEIRA, Gesner; RODAS, João Grandino. Direito e economia da concorrência. P. 339. 


\subsubsection{Instituto do bem jurídico penal}

Este instituto foi concebido e desenvolvido com o intuito de limitar a utilização do Direito Penal pelo Estado apenas para os fatos realmente danosos à existência social, impedindo o seu uso indiscriminado.

No final do século XVIII, PAUl Johann ANSElm RitTer Von Feuerbach trouxe uma primeira limitação à aplicação do Direito Penal, pois entendia que esse ramo do Direito limitava-se a proteger direitos subjetivos, sendo o crime uma ação contrária ao direito do outro. Assim, sem uma lesão a esses direitos, não haveria crime a ser punido, de tal sorte que uma conduta só poderia ser considerada crime se fosse socialmente danosa. ${ }^{123}$

Uma grande crítica à sua teoria consistia no fato de que nem todas as ações estavam sujeitas a essa premissa básica. Várias delas, embora não ofendessem os tais direitos subjetivos, acabavam por ser punidas, como era o caso dos crimes contra a honestidade.

Em 1834, Johan Michael Franz Birnbaum trouxe posicionamento diverso de FEUERBACH, asseverando que os direitos subjetivos não podiam ser lesionados. Ele sustentava que os danos eram provocados no objeto sobre o qual recaía o direito subjetivo. Para o autor, era substancial a existência de um bem fixado no mundo do ser passível de lesão por uma ação delitiva para a tutela penal. Esta nova ideia permitiu que ações de caráter predominantemente imoral e/ou que vulneravam normas de obediência passassem a ser punidas. ${ }^{124}$

Daí origina-se o moderno conceito de bem jurídico, pois, limitando o jus puniendi estatal, passou-se a exigir que a conduta delitiva lesionasse bens e não simples direitos. Em que pese o fato de BIRNBAUM nunca ter utilizado o termo bem jurídico, graças às suas formulações lhe foi atribuída a paternidade desse conceito. ${ }^{125}$

Essa conceituação de BIRNBAUM acentuou-se na valoração dos bens da coletividade, cuja garantia foi sustentada por RUDOLPH VON JHERING, que passou a elaborar uma teoria dos interesses, a qual descreve a exposição ao perigo das condições vitais na sociedade, constatada jurídico-positivamente pelo legislador. Para JHERING, o fim das leis

\footnotetext{
${ }^{123}$ Cf. PRADO, Luiz Regis. Bem jurídico-penal e constituição. P. 30.

${ }^{124}$ ESER, Albin. Sobre la exaltación del bien jurídico a costa de la víctima. P. 18.

${ }^{125}$ Cf. SILVEIRA, Renato de Mello Jorge. Direito penal supra-individual: interesses difusos. P. 40.
} 
penais não haveria de ser outro que não o explicitado por elas mesmas, isto é, a proteção da seguridade das condições de vida da sociedade. ${ }^{126}$

Ao considerar esses preceitos, KARL BINDING sustentou que nem todos os bens fazem jus à proteção do Direito Penal, mas somente os bens jurídicos, ou seja, os que têm relevância jurídica, atribuída exclusivamente pelos legisladores. Isto porque são eles os responsáveis por selecionar os valores cuja defesa entende ser importante para a sociedade. $^{127}$

Mas essa visão predominantemente positivista restou ameaçada pelo risco de arbitrariedade, já que atribuiu desmesurada liberdade ao legislador, de maneira a limitar a criação do bem jurídico a aspectos meramente lógico-formais. Em virtude disso, contrariando essas colocações positivistas, FRAN VON LISZT defendeu que o legislador não pode criar um bem jurídico, mas sim identificá-lo, buscando na sociedade os bens passíveis de proteção pelo Direito Penal. O ponto de partida de sua teoria firmou-se sobre a tese de que o Direito apenas existe pela vontade humana e, portanto, o fim do Direito Penal seria somente a proteção de interesses humanos vitais, os chamados interesses jurídicos.

A partir da Revolução Burguesa, as formulações positivistas começaram a sofrer abalos. As inúmeras transformações sentidas com a nova realidade social que se apresentava apareceram como reação à certeza das leis naturais do pensamento positivista.

A partir do início do século XX, é notável o aparecimento de orientações espiritualistas que, sob a influência da filosofia neokantiana, desenvolveram uma concepção metodológica do bem jurídico. A teoria do bem jurídico espiritualizado, iniciada por RICHARD HONIG, em 1919, desenvolveu a idealização deste com a ratio da norma, tendo em vista que ela não possui existência prévia à das próprias prescrições penais. O bem jurídico deve ser entendido como valor cultural, de caráter abstrato, de cunho ético e juridicamente protegido. ${ }^{128}$

Na década de 1970, BERnd SchÜNEMANN expôs o conceito de bem jurídico intermediário espiritualizado, definindo-o como “[...] bens supra-individuais com caráter imaterial, os quais desempenham verdadeira função de representação, reclamando uma

\footnotetext{
${ }^{126}$ Cf. SILVEIRA, Renato de Mello Jorge. Direito penal supra-individual: interesses difusos. Pp. 41/42.

${ }^{127}$ CABRERA, Raul Peña. El bien jurídico en los delitos económicos. P. 38.

${ }^{128}$ SILVEIRA, Renato de Mello Jorge. Direito penal supra-individual: interesses difusos. Pp. 47.
} 
autonomia e proteção próprias." ${ }^{129}$ Para ele, somente será o bem jurídico considerado como lesionado caso se dê uma reiteração generalizada de condutas que não respeitem as regras básicas. ${ }^{130}$

Ao utilizar da mesma nomenclatura, RICARDO M. MATA Y MARTIN, na Espanha, entende como bens intermediários espirituais aqueles intermediários supraindividuais ou coletivos orientados à proteção de bens individuais ou, ainda, suficientemente determináveis ou individualizados. ${ }^{131}$

Por seu turno, os funcionalistas passaram a alegar que o cumprimento da norma penal visa não a proteção de bens jurídicos, mas o funcionamento da sociedade. Alguns posicionamentos mais radicais, como aquele apresentado por GÜNTHER JAKOBS, descartam, inclusive, a necessidade dos bens jurídicos, tendo em vista que a finalidade do Direito Penal seria apenas assegurar a vigência das normas jurídicas. ${ }^{132}$

Diante de tantas ideias e conceituações, é premente que se considere a extrema imprescindibilidade do bem jurídico para o Direito Penal, constituindo o fundamento de sua aplicação e parâmetro delimitador de sua incidência.

\subsubsection{Bem jurídico penal supraindividual}

Classicamente, existem os bens jurídicos penais de natureza individual, sendo eles divisíveis em relação ao seu titular, com referência direta ao indivíduo. É o bem jurídico penal criado sob uma visão predominantemente antropocêntrica (a vida, a integridade física, o patrimônio e a honra, dentre outros).

Em contraposição a essa abordagem eminentemente individualista do conceito de bem jurídico penal, desenvolve-se o bem jurídico penal supraindividual, com forte influência da ideia da sociedade de risco. Com efeito, a consagração de novas tecnologias na sociedade pós-moderna e as situações de riscos com ela advindas acabaram por dar os

\footnotetext{
${ }^{129}$ Idem. A construção do bem jurídico espiritualizado e suas críticas fundamentais. Pp. 14/15.

130 SCHÜNEMANN, Bernd. Modern Tendenzen in der Dogmatik der Fahrlässigkeits - und Gefährdungsdelikte. Apud SILVEIRA, Renato de Mello Jorge. Direito penal supra-individual: interesses difusos. Pp. 64.

${ }^{131}$ SILVEIRA, Renato de Mello Jorge. Direito penal supra-individual: interesses difusos. Pp. 64/65.

132 JAKOBS, Günther. Fundamentos do direito penal. P. 62.
} 
novos contornos à conhecida sociedade de risco. Contrariamente ao caráter eminentemente pessoal dos riscos anteriormente existentes, os novos riscos passaram a adquirir uma proporção transcendente, afetando toda a coletividade. ${ }^{133}$

Diante dessa nova conjuntura, a tutela penal de bens de conteúdo abstrato tornou-se frequente, de modo que passou a ser cada vez mais difícil identificar em um indivíduo em particular os reflexos dos valores protegidos pelo Direito Penal. A característica principal dos bens jurídicos penais supraindividuais é a titularidade de caráter não pessoal, afetando um grupo de pessoas ou toda a coletividade, sem perder sua referência individual. Portanto, diferem-se dos bens jurídicos de natureza coletiva, pois estes se referem à coletividade $\mathrm{e}$ são indivisíveis em relação aos titulares. Os indivíduos não têm disponibilidade de determinado bem sem afetar os demais.

Ao analisar o surgimento dos bens jurídicos supraindividuais, ALICE BIANCHINI faz uma abordagem sob o ponto de vista da tutela da ordem econômica:

\footnotetext{
"A preocupação com condutas que venham a violar a ordem econômica, tal qual ocorre em relação ao meio ambiente, passaram a integrar o direito repressivo há pouco tempo, constituindo-se em modernas formas de criminalidade. Suas peculiaridades diferem, sobremaneira, da denominada criminalidade clássica, já que transcende direitos consagrados no âmbito individual, para ocupar-se com a violação de bens jurídicos cuja ofensa afeta a coletividade, ainda que não se possa percebê-la diretamente. Possui, portanto, caráter supra-individual." 134
}

Cumpre ressaltar que o fato de os danos a que estão sujeitos esses bens específicos não serem facilmente identificáveis nem existirem vítimas determinadas estimula o recurso do legislador aos crimes de perigo, sobretudo de perigo abstrato, tutelando os bens de toda e qualquer agressão, em plena afronta ao princípio da ofensividade. Desta forma, tem-se a blindagem do bem jurídico contra qualquer dano de um lado e a tutela de situações puramente abstratas de outro, violando-se o princípio da ultima ratio do Direito Penal.

\footnotetext{
${ }^{133}$ ROBALDO, José Carlos de Oliveira; VIEIRA, Vanderson Roberto. A sociedade de risco e a dogmática penal.

${ }^{134}$ BIANCHINI, Alice. Direito penal econômico: os fins justificam os meios? P. 09.
} 
$\mathrm{Na}$ tentativa de possibilitar a inserção desses novos bens jurídicos penais e a ação do Estado contra a denominada criminalidade moderna, em consonância com os princípios de Direito Penal, surgem várias teorias dogmáticas, tais como o direito de intervenção de WINFRIED HASSEMER.

Especificamente acerca desta teoria, insta registrar, em breves linhas, que o direito de intervenção recebeu sua teorização inaugural em países como Itália, Espanha, Alemanha, França e Portugal e sua origem revela que se trata da regulação, restrita ao campo extrapenal, de funções revestidas de interesse público. É uma forma de tutela de relevantes valores sociais protegidos por normas repressivas, sem a utilização de sanções penais.

Os objetivos desse ramo do Direito estão intimamente vinculados à busca de interesses gerais e públicos e suas vertentes são, em caráter funcional, distintas em numerosos domínios, diferentemente do que ocorre com o Direito Penal, inspirado exclusivamente por uma obsessão de garantias individuais. ${ }^{135}$

Este novo ramo do Direito estaria situado entre o Direito Penal e o Direito Administrativo sancionador, entre o Direito Civil e o Direito Público, trazendo um nível de garantias e formalidades processuais inferior ao do Direito Penal e, por outro lado, uma carga reduzida de sanções. A este direito de intervenção caberiam os delitos que não viessem a ofender, de maneira intensa, diversos bens. ${ }^{136}$

Nesse contexto, a legitimidade da proteção desses bens supraindividuais é possível, desde que eles se baseiem nos interesses fundamentais da vida social da pessoa. Assim, a ampliação do horizonte penal para a tutela desses bens nunca deve perder o referencial dos elementos autônomos.

\subsubsection{Fundamentos da tutela penal da concorrência: a concorrência como bem jurídico penal supraindividual}

“[...] dificilmente, porém, conhecerá a ciência penal matéria que suscite maior desencontro de opiniões. Tudo é questionado e controvertido nesta Babel em

\footnotetext{
135 OSÓRIO, Fabio Medina. Direito administrativo sancionador. Pp. 150/151.

${ }^{136}$ SILVEIRA, Renato de Mello Jorge. Direito penal supra-individual: interesses difusos. P. 68.
} 
que se tornou a doutrina da dignidade penal e da necessidade de tutela penal.

E onde, falando todos do mesmo, raros são os que falam da mesma coisa.

Não havendo, por isso, consenso estabilizado em relação a praticamente nenhum dos aspectos mais decisivos."

Ao tratar desse assunto, é basilar, desde o início, salientar que o "[...] fundamento primeiro do injusto material deita suas raízes na Lei Máxima." ${ }^{138} \mathrm{Sim}$, pois a Constituição Federal dita as diretrizes político-criminais de um país, exercendo função orientadora na decisão de seleção das condutas que serão reprimidas pelas sanções penais. Os valores expostos na Carta Fundamental são aqueles mais caros à sociedade e, para tanto, merecem ser tutelados pelos meios repressivos existentes em nosso ordenamento jurídico. ${ }^{139}$

Isto não significa, com base nessa teoria constitucional do bem jurídico, que não exista um limite à intervenção penal, ainda que o permissivo constitucional seja amplo. Assim, a Constituição Federal

\begin{abstract}
“[...] indica a razão inicial, o fundamento necessário da tutela penal, uma vez que, quanto a esta, entram em consideração também ulteriores razões e balanceamentos de interesses quanto à posição, extensão e modo, a partir da relação liberdade autoridade." 140
\end{abstract}

A despeito de haver uma autorização constitucional, o legislador não está obrigado a efetivar a aplicação do Direito Penal, que se deve incidir em relação a bens dignos de

\footnotetext{
${ }^{137}$ ANDRADE, Manuel da Costa. Op. cit., p. 175.

${ }^{138}$ PRADO, Luiz Regis. Bem jurídico-penal e constituição. P. 08.

${ }^{139}$ RODOLFO TIGRE MAIA acolhe entendimento diverso, segundo o qual: "[...] os bens jurídicos, para serem objeto de proteção por uma norma jurídico-penal incriminadora, não precisam obrigatoriamente estar previstos na Constituição. Com efeito, inúmeros e relevantes valores comunitários (e.g., a Ecologia, as relações de consumo etc) eram inegavelmente dotados de dignidade penal mesmo antes de alcançarem recentemente o efetivo status constitucional, e sua proteção jurídico- criminal já havia sido legitimamente tida por necessária preexistindo esta chancela." Admite, porém, “[...] o inequívoco valor hermenêutico que tem tal previsão, quando existente, em termos do estabelecimento da efetiva dignidade penal de um bem jurídico". Conclui afirmando que "[...] por força imediata de sua inserção dentre os valores constitucionais mais destacados, parece estar assegurado o aspecto da dignidade penal da ordem econômica, em seus múltiplos aspectos, ao menos no ângulo do reconhecimento da presença de um bem jurídico coletivo de inegável relevo comunitário.” (MAIA, Rodolfo Tigre. Tutela penal da ordem econômica: o crime de formação de cartel. Pp. 124/125.

${ }^{140}$ GOMES, Mariângela Gama de Magalhães. O princípio da proporcionalidade no direito penal. P. 94.
} 
tutela penal, respeitando-se o princípio da subsidiariedade, isto é, quando outros recursos se mostrem ineficientes. ${ }^{141}$

Ao seguir este critério, forçoso concluir que a ordem econômica insere-se inequivocamente nesse contexto constitucional. ${ }^{142}$

Vale notar, à luz de uma visão sistemática de nossa Carta Magna, que a repressão à ordem econômica deriva do fato de ser atentatória aos fundamentos da República do Brasil dispostos no artigo $1^{\circ}{ }^{143}$

Com relação à antiga Constituição, percebe-se que a livre iniciativa não é mais considerada pelo legislador constituinte de 1988 apenas como um princípio, mas sim um direito, um meio utilizado na ação econômica.

A livre iniciativa é um valor básico que reforça ser o Estado Brasileiro um Estado Democrático de Direito. Representa a livre eleição da atividade e dos meios de que se deve

${ }^{141}$ Para Dulce MaRIa SANTANA VEGA “[...] la Constitución ofrece al legislador 'um catalogo' de bienes jurídicos que se estiman dignos de protección. Pero, lo que decide si esta protección va a ser civil, administrativa o penal se determinará em el si por el mencionado princípio de intervención mínima y en el cómo por los otros princípios fundamentadores de Derecho penal que ejercen así su función delimitadora." (La proteción penal de los bienes jurídicos colectivos. p. 47).

${ }^{142}$ Em seu Título VII, denominado Da ordem econômica e financeira, nossa Carta Magna preceitua: "[...]

Título VII

DA ORDEM ECONÔMICA E FINANCEIRA

Capítulo I

DOS PRINCÍPIOS GERAIS DA ATIVIDADE ECONÔMICA

[...]

Art. 170. A ordem econômica, fundada a valorização do trabalho humano e na livre iniciativa, tem por fim assegurar a todos existência digna, conforme os ditames da justiça social, observados os seguintes princípios:

I - soberania nacional;

II - propriedade privada;

III - função social da propriedade;

IV-livre concorrência;

$V$ - defesa do consumidor;

$V I$ - defesa do meio ambiente, inclusive mediante tratamento diferenciado conforme o impacto ambiental dos produtos e serviços e de seus processos de elaboração e prestação;

VII - redução das desigualdades regionais e sociais;

VIII - busca do pleno emprego;

IX - tratamento favorecido para as empresas de pequeno porte constituídas sob as leis brasileiras e que tenham sua sede e administração no País.

Parágrafo único. É assegurado a todos o livre exercício de qualquer atividade econômica, independentemente de autorização de órgãos públicos, salvo nos casos previstos em lei."

143 “Art. 1". A República Federativa do Brasil, formada pela união indissolúvel dos Estados e Municípios e do Distrito Federal, constitui-se em Estado Democrático de Direito e tem como fundamentos: [...].

IV - os valores sociais do trabalho e da livre iniciativa;" 
utilizar na execução da atividade econômica. ${ }^{144}$ Saliente-se que os princípios da livre iniciativa e da livre concorrência são instrumentais da própria dignidade humana, porque a Constituição Federal de 1988 persegue objetivos maiores e mais amplos do que apenas o livre mercado. Aliás, todos os princípios veiculados no artigo 170 da Carta Magna têm por finalidade assegurar a todos a existência digna, conforme os ditames da justiça social. ${ }^{145}$

Destarte, primando a Constituição Federal pelo respeito ao livre mercado, livre iniciativa, livre concorrência, em seu artigo $173, \S 4^{\circ}$, ratifica a importância de uma saudável e livre vida econômica no País, dispondo que "A lei reprimirá o abuso do poder econômico que vise à dominação dos mercados, à eliminação da concorrência e ao aumento arbitrário de lucros". 146

Essa expressão utilizada pelo legislador constituinte - a lei reprimirá - suscita uma série de questionamentos na doutrina no sentido de saber se esta repressão é necessariamente representada pela via penal.

GONÇALO FARIAS DE OliveIRA JÚNIOR demonstra que a Constituição Federal não só declarou a ordem econômica como valor relevante para a sociedade, digna, portanto, de tutela, mas afirmou expressamente a necessidade de tutela penal. Vejamos:

\begin{abstract}
"Quando o constituinte originário facultou ao legislador - pelo art. 173, §4 reprimir penalmente o abuso de poder econômico que vise à dominação dos mercados, à eliminação da concorrência e ao aumento arbitrário dos lucros, o fez ante a relevância dos bens jurídicos que orientam a economia de mercado. Fica patente, assim, que a Constituição não se contentou em apenas declarar formalmente os valores e a principiologia fundantes da vida econômica do país, mas confirmou a necessidade da tutela penal da ordem econômica - tal como regulada normativamente - e, por conseguinte, da livre iniciativa e da liberdade concorrencial, cumprindo ao Poder Legiferante infraconstitucional a indicação dos casos sujeitos à punibilidade do Estado.
\end{abstract}

\footnotetext{
144 FERRARI, Eduardo Reale. Legislação penal antitruste: direito penal econômico e sua acepção constitucional. P. 585.

${ }^{145}$ FORGIONI, Paula A. Op. cit., p. 191.

${ }^{146}$ Consoante leciona CALIXTO SALOMÃo FILHO: "É importante que se entendam as conseqüências desse dispositivo constitucional, que é frequentemente mal-interpretado. Em primeiro lugar, é preciso que fique claro que a concentração do dispositivo constitucional na figura do abuso do poder econômico não implica que essa figura seja a única ilícita para a ordem concorrencial. Se assim fosse não haveria razão para a previsão expressa da liberdade de concorrência no inciso IV do art. 170. É nesse dispositivo que se baseia, por exemplo, a regulamentação da concorrência desleal que, como visto supra, prescinde da existência de poder econômico." (SALOMÃO FILHO, Calixto. Direito concorrencial: as condutas. P. 107).
} 
(...) A ratio fundamentalis da incriminação, é lícito afirmar, funciona como meio de satisfação dos interesses da ordem jurídica da economia, reclamando a atuação do Estado - pelo Direito Penal - como forma de garantir a fluência das relações econômicas sem o cometimento de abusos por parte dos sujeitos que delas participam.

O fato importante é que, na práxis, a liberdade de concorrência abre a possibilidade às manifestações do poder econômico supressivo da própria concorrência, capacitando a dominação em detrimento do mercado livre. Como contra-resposta, porém, tem-se a intervenção penal versada na legislação em tela, que busca preservar as estruturas do mercado sem extirpar a permitida hegemonia dos monopólios e oligopólios, justamente porque somente a formação abusiva destes é que contraria a lógica da economia capitalista de mercado." ${ }^{147}$ (grifos do autor)

Assim, teria a Constituição Federal de 1988 acolhido, por intermédio do artigo 173, $\S 4^{\circ}$, a intervenção penal como mecanismo de combate às condutas de abuso de poder econômico, que visem a dominação de mercados, a eliminação da concorrência e o aumento arbitrário dos lucros, sem descartar a via repressiva administrativa.

Na mesma linha, JosÉ CRETELla JR. sustenta o firme entendimento segundo o qual "[...] a lei a que se refere o $\S 4^{\circ}$ do artigo 173, reprimindo o abuso do poder econômico, é lei penal”. 148

EdUARDo REAlE FERRARI, por seu turno, entende não ter sido essa a visão teleológica do legislador constituinte de 1988, pois

“Ao nosso ver, a própria interferência da via penal no âmbito econômico já
constitui sinal do fracasso da convivência harmônica entre os cidadãos, não
nos parecendo ser o castigo e a perseguição por meio da via criminal, o meio
mais adequado para tutelar os dirigentes da comunidade que atentarem contra
o livre mercado, fortificando tal pensamento, especialmente, em face dos fatos
de que a maioria das punições penais econômicas já estão resguardadas por
outras vias como a seara administrativa e a privada, cabendo muito mais

${ }^{147}$ OLIVEIRA JÚNIOR, Gonçalo Farias de. Op. cit., pp. 121/122.

${ }^{148}$ FRANCESCHINI, José Inácio Gonzaga. Introdução ao direito da concorrência. P. 16. 
pregar por uma reestruturação da Ordem Administrativa do que pela

enunciação desenfreada da legiferação penal." 149

Apesar de partilharmos desse mesmo posicionamento, observando que realmente não há demonstrações cristalinas de que a Carta Magna brasileira pretendeu a repressão penal das condutas atentatórias à ordem econômica e considerando o caráter subsidiário e de ultima ratio do Direito Penal, não foi esse o caminho trilhado pelo legislador infraconstitucional.

Após a promulgação da Constituição Federal, foram elaboradas as Leis $\mathrm{n}^{\circ} \mathrm{s}$ 8.137/90, no âmbito penal, e 8.884/94, voltada à repressão no âmbito administrativo. Ambas, “[...] vinculam-se, constitucionalmente ao conhecido trinômio 'dominação de mercado', 'eliminação de concorrência' e 'aumento arbitrário de lucros' (o chamado lucro supracompetitivo)." $150 \mathrm{O}$ mesmo caminho trilhou a recém-promulgada Lei $\mathrm{n}^{\circ}$ 12.529/11, que substituiu a de $n^{\circ} 8.884 / 94$.

Preservadas as autonomias de ambas as esferas - penal e administrativa coexistem as legislações, ainda que repouse uma série de críticas quanto à (in)dependência dessas instâncias. ${ }^{151}$

149 FERRARI, Eduardo Reale. Legislação penal antitruste: direito penal econômico e sua acepção constitucional. P. 586.

${ }^{150}$ FRANCESCHINI, José Inácio Gonzaga. Introdução ao direito da concorrência. P. 19.

${ }^{151}$ A respeito da inter-relação das searas administrativa e penal econômica, EDUARDO REALE FERRARI expõe as três possibilidades de atuação entre elas, elaboradas por GÜNTER HEINE:

"A primeira seria a de total dependência entre os sistemas penal e administrativo, não havendo sentido a cumulatividade sancionatória, porquanto há uma visão de estrita relação material entre as searas visando primeiramente garantir juridicamente o cumprimento das decisões administrativas para a partir de então, analisar se há ou não a infração penal econômica. Visa-se não apenas respaldar as disposições administrativas mas reforçar sua execução a fim de evitar choques entre as instâncias inter-relacionadas.

A segunda possibilidade pregaria por um direito penal relativamente dependente da administração, também denominado funcionamento alternativo, donde optar-se-ia pela seara administrativa com conseqüente descriminalização de assunto afetos à área econômica de menor relevância, não configurando-se a via criminal o meio adequado 'prima ratio' para a intervenção estatal priorizando-se a atuação e o sancionamento no âmbito administrativo, incidindo a área penal apenas em casos extremamente imprescindíveis e como última forma de controle social. Trata-se do funcionamento coordenado, também chamado sistema misto, donde prever-se-ia a utilização da via penal, apenas aos casos em que a conduta administrativa não conseguisse almejar execução, havendo um critério de seleção para a interferência penal.

A terceira proposta seria a total independência entre as instâncias, donde, em face da ofensividade da conduta, imprescindivel seria a atuação de ambas as searas, fundando-se em que por serem condutas de perigo abstrato que atinge integralmente a coletividade, necessária seria quer a intervenção administrativa como a criminal.” (FERRARI, Eduardo Reale. Legislação penal antitruste: direito penal econômico e sua acepção constitucional. P. 608). 
Contudo, especificamente no âmbito penal, mesmo em se tratando de tutela aparentemente indispensável para alguns, a compreensão e entendimento da legislação nessa ambiência é dificultosa, considerando o

\begin{abstract}
“[...] acurado tecnicismo terminológico e da relatividade fluidez conceitual que a envolvem (instabilidade e relatividade de suas normas, em razão de variáveis político-econômicas), o que dá lugar a tipos penais altamente complexos e imprecisos." 152
\end{abstract}

Não por acaso, a aplicação da Lei $n^{\circ} 8.137 / 90$ encontra caminho tortuoso, cheio de obstáculos.

Referido diploma legal traz tipos penais abertos em demasia, impregnados de elementos normativos e de expressões carentes de complementação. Apresenta uma série de condutas esparsas - ao todo são 70 comportamentos delituosos -, distribuídas em pouco mais de vinte dispositivos.

Independentemente do acerto do legislador na redação técnica utilizada, parece que a intervenção do Estado na atividade econômica, para assumir seu novo papel de Estado dirigente, trouxe a necessidade de criminalização de condutas até então imprevisíveis. ${ }^{153}$ Mas é impensável seja suprimido o caráter de ultima ratio do Direito Penal, isto é, de uma intervenção penal mínima; é, no mínimo, temeroso que o alargamento do Direito Penal para áreas onde prevalece o interesse de caráter coletivo, intangível e com vitimização difusa, represente um uso desmedido da sanção penal, levando a uma intervenção de caráter meramente simbólico. ${ }^{154}$

Além disso, a permissão para a intervenção penal nessa área faz aflorar forte tendência à criação de figuras delitivas para proteção de bens jurídicos supraindividuais que trazem ínsito um perigo, autorizando a sanção de condutas que sequer podem provocar lesão concreta para o interesse protegido. ${ }^{155}$

\footnotetext{
152 PRADO, Luiz Regis. Direito penal econômico: ordem econômica, relações de consumo, sistema financeiro, ordem tributária, sistema previdenciário. P. 27.

${ }^{153}$ RIOS, Rodrigo Sánchez. Reflexões sobre o delito econômico e sua delimitação. P. 442.

154 OLIVEIRA JÚNIOR, Gonçalo Farias. Op. cit., p. 133.

155 Nesse sentido, CARLOS MARTÍNEZ-BUJÁN PÉREZ: “[...] vinculado no seu nascimento ao que se conhece como a 'Escola de Frankfurt' (Hassemer, Herzog, Naucke, Albrecht) que tem criticado severamente a
} 


\title{
Nessa toada, Miguel Bajo FernandeZ e SiLvina Bacigalupo expõem
}

\begin{abstract}
“[...] en efecto muchas de las tipificaciones de lege data, o de las que deberiam crearse de lege ferenda, non son más que formas de peligro abstrato de biens cuya lesión se castiga através de outras figuras delitivas. En este sentido, en el Derecho penal económico no se espera a que el acreedor o el consumidor resulte lesionado en su derecho de credito o en su patrimonio para castigar la falsedad contable o de balances o la competencia lícita."156
\end{abstract}

Como resposta a essas críticas, partindo de uma reflexão sobre a forma de enfrentar a questão econômica, surgiu uma vertente segundo a qual o poder punitivo do Estado contra certas modalidades de criminalidade de natureza econômica seja exercitado por uma "terceira via", situada entre o Direito Penal e o Direito Administrativo, conjugando a rigidez de um e a fluidez do outro. É o chamado direito de intervenção, já abordado anteriormente.

Com a adoção desta via, restariam afastadas as “[...] pesadas sanções do direito penal, sobretudo as sanções de privação de liberdade e que, ao mesmo tempo, possa ter garantias menores [...]”, mas mantidos “[...] os princípios garantistas próprios do direito penal, aplicáveis às infrações administrativo-penais, bem como os princípios ordenadores do conjunto normativo". 157

Acolhido esse terceiro caminho, seria elaborado um novo conjunto de leis que apresentaria um ordenamento mais célere. As infrações seriam administrativas e não penais ${ }^{158}$ e seus autores estariam submetidos ao julgamento de um conselho ou tribunal administrativo, composto por membros “[...] revestidos de garantias e sujeitos a vedações

decisão de que o direito penal estenda seu objeto para além dos seus limites o que tradicionalmente tem sido a proteção dos bens jurídicos clássicos - e que acabe convertendo-se num direito penal meramente funcionalista, orientado exclusivamente à finalidade de lograr uma defesa da sociedade o mais eficaz possível diante dos riscos derivados das disfunções do moderno sistema social." (PERÉZ, Carlos MartínezBuján. Derecho penal económico. Parte General, p. 02. Apud RIOS, Rodrigo Sanchez. Reflexos sobre o delito econômico e a sua delimitação. P. 435).

${ }^{156}$ FERNANDEZ, Miguel Bajo; BACIGALUPO, Silvina. Derecho penal económico. Pp. 59 e ss.

${ }^{157}$ REALE JÚNIOR, Miguel. Despenalização no direito penal econômico: uma terceira via entre o crime e a infração administrativa? Pp. 124 e ss.

${ }^{158}$ No presente trabalho, adota-se posicionamento segundo o qual não há diferença ontológica entre os bens tutelados economicamente pelo âmbito administrativo quando comparado com o penal. Tanto um quanto outro tutelam a ordem econômica e o regular desenvolvimento do livre mercado. Verifica-se que a diferença entre a interferência penal ou administrativa reside na natureza política da sanção proposta por elas individualmente, de maneira que é apenas formal a distinção entre os âmbitos de atuação. 
que [assegurasse] a imparcialidade e independência das decisões [...]",159, sem a burocracia existente em nosso Poder Judiciário. ${ }^{160}$ A razão de se adotar essa terceira via visa cada vez mais evitar a intervenção penal no âmbito econômico, revalorizando os agentes do Estado, as céleres estruturas administrativas e eliminando as burocracias e morosidades do Direito Penal.

De toda sorte, a despeito das críticas e ponderações formuladas, pode-se concluir que, sob o ponto de vista sistêmico de origem constitucional, há fundamento formal para a tutela penal da ordem econômica, assim como o há para toda e qualquer via repressora existente em nosso ordenamento.

O artigo 173, $\S 4^{\circ}$ da Constituição Federal permite que haja repressão ultimada por várias vias, cabendo analisar inicialmente se basta a aplicação do âmbito administrativo para, posteriormente, verificar se é preciso e conveniente a intervenção da via penal.

A par dessa permissibilidade constitucional, é imprescindível fazer a análise do fundamento da proteção penal da concorrência sob o aspecto do bem jurídico. A esse respeito, depreende-se de considerações feitas em itens anteriores que a concorrência possui diversos pontos em comum com os bens jurídico-penais supraindividuais, de maneira a enquadrar-se em seu conceito.

Consoante sustenta Eduardo Novoa Monreal, “[...] temos que precisar que o delito econômico [...], incluídos aqui os crimes concorrenciais, “[...] não causa por si mesmo um dano (lesão ou perigo) a pessoa ou pessoas determinadas, pois seu dano se difunde sobre toda a nação, sem radicar-se sobre nada em particular; por esta razão

\footnotetext{
${ }^{159}$ REALE JÚNIOR, Miguel. Despenalização no direito penal econômico: uma terceira via entre o crime e a infração administrativa? P. 124.

${ }^{160}$ Ao esclarecer as ideias de HASSEMER sobre o direito de intervenção, RENATO DE MELLO JORGE SILVEIRA sustenta que: "Para ele, a chave conclusiva seria como Janus. De um lado, dever-se-ia reduzir o Direito Penal a um Direito Penal básico, em que se ajustassem todas as lesões dos bens jurídicos individuais clássicos, além das situações de perigo grave, como incêndio, condução de veículos sob influência alcoólica, formação de quadrilhas etc. Ao mesmo tempo, proteger-se-iam aqui, também, bens jurídicos universais (supra-individuais), necessários ao ordenamento do próprio Estado. Ao lado disso, ter-se-ia a criação de um Direito de Intervenção (Interventionsrech), situado entre o Direito Penal e o Direito Administrativo sancionador, entre o Direito Civil e o Direito Público, com um nível de garantias e formalidades processuais inferior ao do Direito Penal, mas igualmente acompanhado de uma carga reduzida de sanções. A esta classe inovadora caberiam os delitos que não viessem a agredir, de maneira intensa, diversos bens." (SILVEIRA, Renato de Mello Jorge. Direito penal supra-individual: interesses difusos. P. 68).
} 
trata-se de um dano que não é quantificável ou singularizável [...]”. ${ }^{161}$ E não é outra a principal característica dos bens jurídicos penais supraindividuais. ${ }^{162}$

Por certo, a estrutura competitiva que se protege com os delitos concorrenciais caracteriza-se, invariavelmente, como interesse supraindividual da vida econômica. ${ }^{163}$ Ocorre que, apesar de a organização social contemporânea clamar pela proteção desses bens supraindividuais, é forçoso avaliar se, de fato, é exigida a intervenção do Direito Penal para essa tutela. Deve-se considerar que a elevação desses interesses à categoria de bens protegidos penalmente pode levar à dissolução do próprio conceito de bem jurídico. ${ }^{164}$

Isto porque, a excessiva abstração e espiritualização dos interesses difusos impede sua definição clara e, por consequência, a sua utilidade como instrumento de limitação do Direito Penal. Aliás, esta tendência de desvincular a norma penal do conceito de bem jurídico mais clássico, em especial sob o ponto de vista antropocêntrico, acaba por conduzir a uma utilização do Direito Penal como mero reforço de normas administrativas sancionadoras.

Sobre a excessiva espiritualização do bem jurídico, RICARDO M. MATA Y MARTíN assevera que "El problema que se le crea com esto a la teoria del bien juridico se ve claramente; los bienes de proteccíon de esta calidad conceptual no permiten criticar um

\footnotetext{
${ }^{161}$ MONREAL, Eduardo Novoa. Reflexões para a determinação do delito econômico. P. 112.

162 RENATO DE MELlo JORGE SILVEIRA ressalta essa específica característica dos bens supraindividuais explanando: "Todos estes bens têm em comum o fato de não tutelar direitos ou interesses de uma pessoa, mas sim, direitos ou interesses de uma coletividade. A titularidade não é assim individual, mas compartilhada por todos os cidadãos ou, ao menos, por uma coletividade de pessoas (mesclando-se, pois, as idéias presentes na legislação nacional quanto a interesses difusos e coletivos), com independência de que essa proteção sirva a cada um dos cidadãos para lograr seu desenvolvimento individual. Conseqüencia imediata desta assertiva é o fato de que ninguém teria a capacidade individual de disponibilidade quanto a estes bens." (SILVEIRA, Renato de Mello Jorge. Direito penal supra-individual: interesses difusos. P. 59).

${ }^{163}$ ULYSSES GUIMARÃES, em seu parecer como relator designado da Comissão de Constituição e Justiça, em 28 de abril de 1961 sobre a antiga Lei Antitruste - Lei n 4.137/62, sustenta a ideia de que a concorrência é um bem jurídico penal institucional que deve ser preservado: "Por definição constitucional, somos uma economia competitiva, vale dizer polêmica de luta entre contrários, de controvérsia. Isso é mais do que constitucional, porque institucional, uma vez que é o regime ou a democracia na ordem econômica. É o pendant na indústria, comércio, agricultura, do insubstituível diálogo entre oposição e governo na ordem política. É a inconveniência dos contrários. Numa democracia econômica, não há ordem econômica única absorvida pelo Estado, muito menos por particulares. O regime é pluripartidário na ordem política e pluriempresarial na ordem econômica. Aí está porque o monopólio, os trustes, os cartéis, os pools, os dumpings, o lookout, holdings, rackets e ententes, quando suprimem a concorrência, são conspirações contra o Estado e a bolsa do povo. Eis porque, mais do que um crime, são uma traição. O Estado que não puder vencê-los, por eles será vencido. Integram o governo invisível.” (SHIEBER, Benjamin M. Abusos do poder econômico. P. 52, grifos do autor).

${ }^{164}$ BOTTINI, Pierpaolo Cruz. Crimes de perigo abstrato. P. 183.
} 
tipo penal por su excessiva amplitud [...]"165 e somado a isso a desenfreada criação de tipos penais de perigo abstrato, ${ }^{166}$ como já visto anteriormente.

Assim sendo, o bem jurídico passa a ser utilizado como justificativa para a intervenção do Direito Penal em novos setores e não como limite a esse expansionismo penal. Diante disso, é premente recuperar a capacidade crítica do conceito de bem jurídico, especialmente quando se tratar de bens jurídicos supraindividuais, à luz de um referencial antropocêntrico. Um bem jurídico será merecedor de tutela penal apenas se, ainda que de maneira mediata, garantir a existência de interesses individuais indispensáveis para a materialização da dignidade humana.

Ao final, a questão que se coloca não é a legitimidade da proteção dos bens jurídicos coletivos ou supraindividuais em si, mas a determinação do substrato material que justifique a intervenção penal. ${ }^{167}$ A adoção desta linha de pensamento implica, assim, na ilegitimidade daqueles tipos penais que não se lastreiem em valores vultosos à concretização da dignidade humana. Sob essa vertente, não se afigura a concorrência bem jurídico supraindividual merecedor da intervenção penal, o que não quer dizer que a sua tutela não deva ser realizada por outras vias. ${ }^{168}$

Feitas essas ponderações, resulta evidente que o fato de a livre concorrência estar prevista como elemento essencial da ordem econômica em nível constitucional e se enquadrar, institucionalmente, como bem jurídico penal supraindividual não basta para justificar a obrigatoriedade do uso da via penal para a sua tutela.

\footnotetext{
${ }^{165}$ MATA Y MARTÍN, Ricardo M. Bienes jurídicos intermédios y delitos de peligros. P. 5.

${ }^{166}$ Sobre o tema, RENATO DE MELLO JORGE SILVEIRA expõe que "[...] a proteção dos bens jurídicos supraindividuais se faz de modo muito particular, principalmente mediante a criação de crimes de perigo abstrato. Nestes, como menciona a doutrina majoritária (senão unânime), afirma-se que não há a constatação de uma lesão efetiva a bem jurídico. Daí, aliás, uma das críticas formuladas quanto à sua presença no Direito Penal." (SILVEIRA, Renato de Mello Jorge. Direito penal supra-individual: interesses difusos. P. 65).

${ }^{167}$ VEGA, Dulce Maria Santana. Op. cit., p. 83.

${ }^{168}$ Acerca da tutela dos interesses difusos, RenATO DE MELlo Jorge Silveira assim se posiciona: "A tutela dos interesses difusos iniciou por trilhar um caminho que inovou o Direito Penal. Mostrando as diferenças que estes interesses guardam dos interesses individuais, devem-se buscar novas formas para o combate dessa criminalidade pós-industrial. A utilização de mecanismos como é o caso da imputação objetiva, por outro lado, não implica em uma revalidação do Direito Penal. Tal utilização, necessária que é, para a confirmação do evento danoso penalmente relevante, denota o caráter híbrido que o Direito de Intervenção deve ter. Utilizando-se de elementos do Direito Penal, Civil e Administrativo, delineia-se nova forma de combate aos crimes contra os interesses difusos. Esta nova visão do problema, por certo, não deve implicar em mera prisão, mas sim em outra multiplicidade de sanções, as quais hão de se mostrar mais eficazes tanto na repressão quanto na prevenção. Quiçá, dessa forma, melhor se consiga defender aquilo que hoje só simbolicamente é protegido." (SILVEIRA, Renato de Mello Jorge. Direito penal supra-individual: interesses difusos. Pp. 216/217).
} 
A defesa do sistema concorrencial depende claramente do desestímulo a possíveis ações que venham a enfraquecê-lo, de modo que é insuficiente mera previsão legal para reparação dos danos. Esse caráter preventivo buscado pela tutela da concorrência depende de instrumentos sancionatórios eficientes, nem sempre encontrados na esfera penal, muito embora haja fundamento formal para se adotar esta via. ${ }^{169}$

169 À guisa de conclusão, extraiu-se o seguinte excerto da obra de EDUARDo REALE FERRARI: “[...] concluímos que, não obstante ser a seara econômica, ordem de cunho constitucional, desnecessária constitui a obrigatoriedade da criminalização para repressão ao abuso do poder econômico, investindo todos os esforços na criação de um efetivo Direito Administrativo Sancionador, que ao invés de escamotear as deficiências da seara penal econômica, acabará por adquirir credibilidade e eficiência sancionatória, cabendo-nos despenalizar uma série de condutas atentatórias à ordem econômica buscando novas soluções estruturais, do qual exemplo constitui a reestruturação por um Direito Administrativo imparcial $e$ independente, que prime pelo respeito ao mercado competitivo e especialmente lícito." (FERRARI, Eduardo Reale. Legislação penal antitruste: direito penal econômico e sua acepção constitucional. P. 619). 


\section{CAPÍTULO 3 AS CONDUTAS ANTICONCORRENCIAIS}

\subsection{Contexto para Identificação das Condutas Anticoncorrenciais}

A fim de atingir a eficácia de seus dispositivos, a Lei $n^{\circ}$ 8.884/94 e a recémaprovada Lei $\mathrm{n}^{\mathrm{o}}$ 12.529/11 não utilizam a ideia de concorrência perfeita, mas sim consideram a existência de um uso abusivo do poder econômico quando a atuação do agente econômico visa influir no mercado de forma a manipular preços ou eliminar concorrentes.

Como é cediço, as concentrações econômicas e o ganho de poder de mercado são, de fato, inevitáveis. Entretanto, quando decorrem de uma estratégia de poder e não de um fenômeno natural, se está diante de um indício de ilicitude da prática daquela conduta. ${ }^{170}$

Nessa perspectiva, o poder econômico é inerente ao livre mercado, sobretudo, porque a organização da economia pauta-se na liberdade de iniciativa e competição, de maneira que entre os agentes econômicos uns são necessariamente mais fortes do que os outros. $^{171}$

Aliás, levando em consideração a própria dinâmica do mercado, todos os agentes que exploram atividade econômica são estimulados a aumentar a sua capacitação, o seu poder econômico de mercado. Afinal, é justamente pelo emprego do poder econômico que o concorrente conquista maior participação no mercado, em disputa com os demais pela busca da preferência do consumidor. ${ }^{172}$

Assim sendo, o poder econômico nada mais é que

“[...] a possibilidade de exercício de uma influência notável e a princípio previsível pela empresa dominante sobre o mercado, influindo na conduta das demais concorrentes ou, ainda, subtraindo-se à influência dessas últimas, através de uma conduta indiferente e delas independente em alto grau. Impossibilitados de enfrentar competidor de maior poder econômico, os

\footnotetext{
${ }^{170}$ FERRAZ JÚNIOR, Tércio Sampaio. Conceito jurídico de oligopólio e a legislação sobre o abuso de poder econômico. P. 193.

${ }^{171}$ COELHO, Fábio Ulhoa. Direito antitruste brasileiro: comentários à Lei no 8.884/94. P. 50.

${ }^{172}$ DUTRA, Pedro. Livre concorrência e regulação de mercados. P. 323.
} 
demais concorrentes, consumidores ou mesmo agentes atuantes em outros mercados encontram-se em posição de sujeição à conduta e aos preços por ele impostos." 173

Nada há de irregular ou ilícito na utilização do poder econômico,

“[...] sendo mesmo a expressão e exercício (daqueles) direitos. No momento em que há abuso do poder econômico, há abuso do direito à liberdade econômica, liberdade de iniciativa, liberdade de concorrência etc. O sujeito passa a fazer um uso 'anormal', 'reprovável', 'ilegítimo', 'imoral' desses direitos." 174

Daí, verificada a utilização deste poder de maneira irregular, em busca da eliminação da livre concorrência, torna-se imperativa a reação repressiva do Estado em face do abuso de poder econômico, consoante prevê a Constituição Federal de 1988.

Assim, o abuso de poder econômico ocorre sempre que uma empresa aproveita a sua condição de superioridade para prejudicar a concorrência, aumentar arbitrariamente os lucros ou inibir o regular funcionamento do mercado. O abuso é detectado quando o agente econômico, detentor de substancial parcela de mercado, age em desconformidade com os seus fins, ultrapassando os limites do razoável. ${ }^{175}$

É, então,

“[...] o comportamento de uma empresa ou grupo de empresas que utiliza seu poder de mercado para prejudicar a livre concorrência, por meio de condutas anticompetitivas. A existência de poder de mercado por si só não é considerada infração a ordem econômica. Somente se uma empresa abusa de seu poder de mercado é que ela pode vir a ser condenada com base na Lei $\mathrm{n}^{\circ}$ 8.884/94." 176

\footnotetext{
${ }^{173}$ NUSDEO, Ana Maria de Oliveira. Defesa da concorrência e globalização econômica - o controle da concentração de empresa. Pp. 240/241.

${ }^{174}$ FORGIONI, Paula A. Op. cit., p. 323.

${ }^{175}$ BRASIL. MINISTÉRIO DA JUSTIÇA. CADE. Cartilha do CADE.

${ }^{176}$ BRASIL. MINISTÉRIO DA JUSTIÇA. CADE. Guia Prático do CADE: A defesa da concorrência no Brasil.
} 
A fim de se inferir o que exatamente configura o abuso do poder econômico ou o seu uso regular e, consequentemente, as condutas caracterizadas como anticoncorrenciais, mister se faz um juízo de legalidade, baseado nos dispositivos constitucionais e infraconstitucionais, sobretudo à luz da Lei no 8.884/94. ${ }^{177}$

Na verdade, a Constituição Federal delineia tais práticas em seu artigo 173, § $4^{\circ}$ como aquelas que visam: a dominação de mercado, a eliminação da concorrência ou o aumento arbitrário de lucros. Em primeiro lugar, para se definir como se dá a dominação de mercados, deve-se considerar o segmento no qual atuam os agentes econômicos, considerando-se a influência que eles exercem nesse mercado específico.

Para esse entendimento, convém delinear o conceito de mercado relevante:

\begin{abstract}
"O mercado relevante abrange todos os produtos ou serviços pelos quais o consumidor poderia trocar, razoavelmente, o produto ou serviço acerca de cuja produção ou distribuição se pesquisa a ocorrência de infração contra a ordem econômica. Se a mercadoria ou o serviço podem ser substituídos, de acordo com a avaliação do consumidor médio, por outros de igual qualidade, oferecidos na mesma localidade ou região, então o mercado relevante compreenderá também todos os outros produtos ou serviços potencialmente substitutos." 178
\end{abstract}

\footnotetext{
${ }^{177}$ Embora a Lei $\mathrm{n}^{\mathrm{o}} 12.529 / 11$ já tenha sido publicada e muito em breve entre em vigor, o presente trabalho foi elaborado sob a égide da Lei $n^{\circ} 8.884 / 94$, o que justifica ser este último o diploma sob análise. De todo o modo, considerando a promulgação da nova legislação e que os seus dispositivos mantiveram a essência, os princípios e conceitos básicos da lei a ser revogada, sempre que pertinentes serão tecidos comentários sobre eles.

${ }^{178}$ COELHO, Fábio Ulhoa. Caracterização da infração contra a ordem econômica. Pp. 90/91.

O autor, sendo mais específico sobre o assunto em outra obra, assim definiu mercado relevante: "A definição do mercado relevante é feita, assim, em dois níveis: o geográfico e o material. A delimitação geográfica do mercado é importante, sobretudo no Brasil, em razão das profundas e variadas diferenças regionais existentes em termos econômicos e mesmo culturais. Não há necessidade de o mercado relevante abranger todo o território nacional, embora em determinadas hipóteses isso aconteça. Ou seja, a relevância a que se reporta o legislador não é função quantitativa do maior ou menor tamanho da base territorial do mercado. Não é necessário, por outro lado, que o mercado relevante mobilize grandes somas de capital, posto que também não é função quantitativa do volume de recursos monetários que movimenta. A delimitação material do mercado é feita a partir da perspectiva do consumidor. O mercado relevante abrange todos os produtos ou serviços pelos quais o consumidor poderia trocar, razoavelmente, o produto ou serviço acerca de cuja produção ou distribuição se pesquisa a ocorrência de infração contra a ordem econômica. Se a mercadoria ou o serviço pode ser perfeitamente substituído, de acordo com a avaliação do consumidor médio, por outros de igual qualidade, oferecidos na mesma localidade ou região, então o mercado relevante compreenderá também todos os outros produtos ou serviços potencialmente substitutos. A definição geográfica e material do mercado relevante, portanto, apenas pode ser feita mediante análise casuística.” (COELHO, Fábio Ulhoa. Direito antitruste brasileiro: comentários à Lei no 8.884/94. P. 58).
} 
Assim, definido o mercado relevante sob estudo, a dominação de mercado será aferida pela participação de determinado agente econômico naquele setor. A Lei $\mathrm{n}^{\circ}$ 8.884/94, em seu artigo $20, \S 3^{\circ}$, impõe como parâmetro uma dominação presumida. ${ }^{179}$ É uma presunção relativa adotada pelo legislador, diante da qual o empresário deve comprovar que, embora possua $20 \%$ de participação no mercado, não possui capacidade de controlar o mesmo. No que concerne a essa porcentagem determinada pelo legislador, é válido ponderar que

"[...] o poder de mercado, quando utilizado para qualificar condutas (em especial o abuso de posição dominante), é basicamente um critério para mensuração de sua eficácia. O critério para sua avaliação é, portanto, eminentemente variável. Assim, mesmo se baseado exclusivamente em uma porcentagem do mercado relevante, o referido critério deve ser dotado de certa flexibilidade, que permita adaptá-lo a cada estrutura de mercado específica." 180

Isso porque: "Uma empresa com uma parcela de mercado relativamente pequena pode ainda ser dominante se nenhum dos outros participantes é suficientemente grande para constituir séria ameaça à sua independência.” 181

Ressalte-se que a empresa que se encontra em posição dominante tende a adotar um comportamento típico de um monopolista, diminuindo a qualidade de seus produtos ou serviços, aumentando preços etc. Basta a influência, o poder de determinar as regras do jogo para o agente econômico tentar neutralizar as forças normais que regem o mercado. ${ }^{182}$

A expressão constitucional eliminação total ou parcial da concorrência implica na limitação de acesso de outros agentes econômicos a determinado mercado, não se apresentando o problema discutido anteriormente de dominação de mercado. O que se vê é o aumento de obstáculos para o ingresso em determinado mercado, a fim de desestimular

179 “[...] Art. 20. (...) $\S 3^{\circ}$ A posição dominante a que se refere o parágrafo anterior é presumida quando a empresa ou grupo de empresas controla $20 \%$ (vinte por cento) de mercado relevante, podendo este percentual ser alterado pelo CADE para setores específicos da economia."

$\mathrm{Na}$ mesma linha dispõe o $\S 2^{\circ}$ do artigo 36 da Lei $\mathrm{n}^{\circ}$ 12.529/11: "Presume-se posição dominante sempre que uma empresa ou grupo de empresas for capaz de alterar unilateral ou coordenadamente as condições de mercado ou quando controlar $20 \%$ (vinte por cento) ou mais do mercado relevante, podendo este percentual ser alterado pelo Cade para setores específicos da economia."

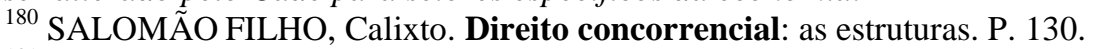

181 PEARSON, Edward S. Law for European Business Studies. Great Britain, 1994. P. 310 (tradução livre). Apud SAYEG, Ricardo Hasson. A proteção do consumidor contra o monopólio. P. 112.

${ }^{182}$ FORGIONI, Paula A. Op. cit., p. 316. 
ou, simplesmente, impossibilitar o novo empresário a iniciar suas atividades naquele nicho. $^{183}$

No tocante à expressão parcialmente, é interessante notar sua imprescindibilidade para que a lei antitruste atinja o seu propósito. A ausência deste termo permitiria graves restrições à concorrência, quando não atingido o grau máximo de prejuízo. ${ }^{184}$

Também repelido pela Constituição Federal, o aumento arbitrário de lucros consiste na “[...] obtenção, por todos os meios, de resultados e vantagens desproporcionais ao valor do investimento efetivamente realizado." 185

É inegável que, dentro de um regime capitalista, o lucro estimula os agentes econômicos a investir recursos em determinado empreendimento no mercado. É, por certo, a mola propulsora da iniciativa dos particulares. Sem o estímulo de ganhos, ninguém se aventuraria em um negócio, ainda mais considerando a sujeição a enormes riscos financeiros.

Dessa forma, as estruturas do livre mercado se fortalecem e se desenvolvem pela busca de lucros, assim como a concorrência entre os empresários alimenta-se da perspectiva de aumento contínuo da lucratividade. ${ }^{186}$

Porém, esse lucro deve ser o resultado da regular exploração da atividade econômica e nada mais, sendo justificáveis sob o ponto de vista da lógica da livre competição. Pressupõe-se que as práticas empresariais que implicam em aumento de lucros sem a apresentação dessas justificativas são arbitrárias, porquanto comprometem as estruturas do livre mercado. ${ }^{187}$

Nessa ordem de ideias, é essencial ressaltar que, a partir dessas formas de abuso, os ilícitos anticoncorrenciais são definidos mediante fórmulas gerais, levando-se em conta a concretização de condutas previstas exemplificativamente no artigo 21 da Lei $n^{\circ}$ 8884/94. ${ }^{188}$

\footnotetext{
${ }^{183}$ SHIEBER, Benjamin M. Op. cit., p. 70.

${ }^{184}$ Idem, ibidem, p. 71.

${ }^{185}$ Apud FRANCESCHINI, José Inácio Gonzaga; FRANCESCHINI, José Luiz Vicente de Azevedo. Poder econômico: exercício e abuso - direito antitruste brasileiro. Pp. 520/521.

${ }^{186}$ COELHO, Fábio Ulhoa. Direito antitruste brasileiro: comentários à Lei no 8.884/94. P. 60.

${ }^{187}$ Idem, ibidem, p. 60.

${ }^{188}$ Condutas similares estão previstas nos diversos incisos do $\S 3^{\circ}$ do artigo 36 da novel Lei $\mathrm{n}^{\mathrm{o}} 12.529 / 11$.
} 
A proteção concorrencial só ganha eficácia real por meio da aplicação simultânea e conjunta de dois subsistemas: o controle das estruturas e o controle das condutas, havendo entre eles uma intensa simbiose. ${ }^{189}$ Abre-se aqui um parêntesis para registrar que o controle das estruturas cuida, basicamente, da concentração e cooperação empresarial. Nessa seara, é elaborada uma previsão sobre o comportamento futuro dos agentes econômicos, com fundamento em seu comportamento pretérito e no mercado em que atuam, ou seja, esse controle não depende diretamente do comportamento adotado pelas empresas, mas sim de características estáveis do mercado. ${ }^{190}$

Já no controle das condutas, o estudo é focado no comportamento dos agentes econômicos de forma individual, podendo, eventualmente, levar a um ganho indevido de poder econômico. É feito um exame das estratégias adotadas pelas empresas que visam estabelecer um poder de dominação do mercado. ${ }^{191}$

Essa relação simbiótica entre os subsistemas se faz evidente, e com bastante intensidade, nos cartéis - objeto dos programas de leniência, tema central do presente estudo. Relativamente a eles, pairam dúvidas na doutrina ao determinar em que sede podem receber tratamento mais adequado: no controle das estruturas ou dos comportamentos?

Nos Estados Unidos da América, tradicionalmente, os cartéis sempre foram tratados entre as condutas anticoncorrenciais. Na Europa, ao reverso, esses acordos entre agentes econômicos são disciplinados entre as estruturas. ${ }^{192}$

Na doutrina pátria, a problemática persiste. Os acordos entre concorrentes estão sujeitos à disciplina das estruturas, em razão do disposto no artigo 54, da Lei no 8.884/94, segundo o qual: “Os atos, sob qualquer forma manifestados, que possam limitar ou de qualquer forma prejudicar a livre concorrência, ou resultar na dominação de mercados relevantes de bens ou serviços, deverão ser submetidos à apreciação do CADE.” 193

\footnotetext{
${ }^{189}$ SALOMÃO FILHO, Calixto. Direito concorrencial: as condutas. Pp. 18/19.

${ }^{190}$ FERRAZ JÚNIOR, Tércio Sampaio. Conceito jurídico de oligopólio e a legislação sobre o abuso de poder econômico. P. 197.

${ }^{191}$ Idem, ibidem, p. 197.

192 SALOMÃO FILHO, Calixto. Direito concorrencial: as condutas. P. 20.

193 Ainda que não haja idêntica redação na recém-aprovada Lei no $12.529 / 11$, seus dispositivos apontam para a adoção da mesma disciplina.
} 
O que se espera, na concepção de CALIXTO SAlomão Filho, ante a ausência de regulamentação estatal clara a respeito de referidos acordos "[...] é que o art. 54 seja utilizado como regra da razão para a análise comportamental dos acordos entre concorrentes (...)”, sendo este “(...) o ponto central de convergência entre o controle das estruturas e o dos comportamentos (...)” e também “(...) o aspecto em que o primeiro mais pode auxiliar o raciocínio necessário para a correta aplicação do segundo.” 194

Nota-se que a atual lei concorrencial não fez distinção entre condutas e estruturas, porquanto seus dispositivos fazem referência a atos em sentido genérico, cujos efeitos possam causar prejuízo ao mercado. ${ }^{195} \mathrm{O}$ legislador apenas evidencia que, para a definição da ilicitude de uma conduta, leva em consideração os efeitos desse ato e não as formas pelas quais se manifesta.

Acerca do assunto, discorre PEDRO DUTRA:

\begin{abstract}
"Acertadamente, ignorou o legislador a forma do ato jurídico que reveste a integração do poder econômico; a norma destina-se aos efeitos a resultar desta integração, irradiados do ato jurídico e projetados sobre o mercado relevante em causa; estes efeitos farão o objeto da análise do órgão de defesa da concorrência, para o fim de verificar se poderão eles limitar ou de qualquer forma prejudicar a livre concorrência, ou resultar na dominação de mercados relevantes, reproduzindo o teor da regra análoga do direito norte-americano, Clayton Act, artigo $7^{\circ} .{ }^{196}$ (grifos do autor)
\end{abstract}

Este é o contexto. A partir de então, passar-se-á a analisar a estrutura do ilícito concorrencial.

\title{
3.2 Estrutura do Ilícito Concorrencial
}

Antes de apresentar a estrutura do ilícito concorrencial, destaca-se que para reger a análise das condutas anticoncorrenciais admite-se, em âmbito nacional, a regra da razão, a qual, como originariamente elaborada, envolvendo a interpretação do Sherman Act pelos

\footnotetext{
${ }^{194}$ SALOMÃO FILHO, Calixto. Direito concorrencial: as condutas. P. 21.

${ }^{195}$ FRANCESCHINI, José Inácio Gonzaga. Direito da concorrência. P. 49.

${ }^{196}$ DUTRA, Pedro. Op. cit., p. 330.
} 
tribunais, ${ }^{197}$ "[...] tinha um objetivo muito simples: tornar viável a aplicação do direito concorrencial”. ${ }^{198}$ É indiscutível que o texto daquele diploma legal não fazia diferença dentre as práticas restritivas, as que traziam prejuízo à concorrência e aquelas que, ao contrário, produziam efeitos positivos.

\title{
Como bem relatou CALIXTO SALOMÃo FILHO:
}

\begin{abstract}
"Mesmo sofrendo certas resistências iniciais, a regra da razão acabou cedo por se firmar, restringindo a aplicação do dispositivo apenas àqueles contratos que causassem uma desarrazoada (unreasonable) restrição ao comércio. A expressão "desarrazoada" envolve dois aspectos. Em primeiro lugar, é necessário que a restrição seja efetiva, ou seja, que realmente restrinja a competição, ao invés de simplesmente estabelecer regras para ela. Esse é o aspecto qualitativo. Em segundo lugar, é necessário que a restrição seja substancial, ou seja, analisadas as condições estruturais de cada mercado, promova uma substancial redução da competição. Esse é o aspecto quantitativo da regra. A fórmula, assim, elaborada pode ser chamada de 'regra da razão no sentido clássico'., 199
\end{abstract}

Tal regra faz sentido na legislação concorrencial, pois

\begin{abstract}
"Como vimos, a finalidade da lei antitruste é proteger e amparar a concorrência no proveito dos consumidores, dos concorrentes atuais e potenciais, e da nação. Em nada adianta para estas finalidades proibir e impedir práticas comerciais que são empreendidas para fins legítimos e nas
\end{abstract}

\footnotetext{
${ }^{197} \mathrm{O}$ artigo $1^{\circ}$ do Sherman Act declara ilícito "[...] todo e qualquer contrato, combinação na forma de truste ou qualquer outra forma, ou conspiração em restrição do tráfico ou comércio entre os Estados, ou com as nações estrangeiras." Logo após a publicação da lei, passou a ter início uma discussão acerca da interpretação dos termos "todo e qualquer contrato (...) em restrição do tráfico e do comércio". Alguns juízes entendiam que essa expressão abrangia todos os contratos que no direito costumeiro fossem considerados como contratos em restrição do comércio - entendimento primeiramente acolhido pela Suprema Corte. Mas essa interpretação ampla e irrestrita dos termos utilizados foi enfraquecendo paulatinamente, pois houve o reconhecimento de que sem uma interpretação limitada das palavras da lei, o Sherman Act estaria coibindo praticamente todos os contratos entre as empresas. Após longas discussões e desentendimentos, em 1911, a Suprema Corte afastou-se da interpretação literal do Sherman Act e enunciou a conhecida regra da razão (rule of reason), especificamente no processo Standard oil Co. of New Jersey v. United States, 221 U.S. 1 (1911). Esta regra hoje é ponto pacífico na interpretação desse diploma legal. O resultado desse debate fez acrescentar a palavra "desarrazoada" ao art. $1^{\circ}$ do Sherman Act, in verbis: "Art. $1^{o}$ - Todo e qualquer contrato, combinação sob a forma de truste ou qualquer outra forma ou conspiração em (desarrazoada) restrição do tráfico ou comércio entre os Estados, ou com as nações estrangeiras, é declarado ilícito pela presente lei [...]” (SHIEBER, Benjamin M. Op. cit., pp. 72/75).

${ }_{198}$ SALOM $\tilde{A}$ O FILHO, Calixto. Direito concorrencial: as condutas. P. 173.

${ }^{199}$ Idem. Direito concorrencial: as estruturas. P. 173.
} 
quais a restrição da concorrência é razoável e necessariamente decorrente do ato praticado. Também vimos que não foi a intenção do legislador reprimir tais práticas, aliás tão enraizadas na vida econômica da nação. De fato, a ilegitimação de tais práticas, em vez de acarretar benefícios para o país, resultaria em prejuízos pelo embaraço destas práticas e pela dissipação das energias do CADE e dos tribunais na tentativa de proibi-las; energias essas que poderiam ser empregadas na luta contra os trustes e outros praticantes de atos que visariam a restringir a concorrência. Portanto, opinamos que as mesmas razões, que levaram os intérpretes norte-americanos a adotar a regra da razão na aplicação do Sherman Act, devem levar os intérpretes brasileiros da lei n. 4.137, o CADE e os tribunais, à mesma conclusão.” 200

Ao contrário da regra da ilegalidade $p e r ~ s e,{ }^{201}$ a regra da razão possibilita uma gama de interpretações a respeito dos dispositivos legais e a adequação de seus instrumentos à realidade social, de maneira que o elemento subjetivo passa a ser um fator predominante para a definição da ilicitude da conduta. ${ }^{202}$ Portanto, infere-se que a análise de uma conduta típica per se poderá ser interrompida em um estágio anterior ao da regra da razão, que exige uma análise mais acurada a respeito da razoabilidade da conduta. ${ }^{203}$

Acerca do assunto, PAUla A. FORGIONI adverte que a regra da razão não se identifica com uma abordagem casuística das práticas analisadas. O case by case approach é um critério que pode ser utilizado pelo intérprete na aplicação de uma norma concorrencial e significa que cada caso deve ser analisado individualmente, dentro de seu contexto específico. Assim, a aplicação desta regra pode dar ensejo a uma análise casuística, mas com ela não se confunde. ${ }^{204} \mathrm{~A}$ adoção desta regra interpretativa resulta evidente a partir do exame do artigo $173, \S 4^{\circ}$, da Constituição Federal, posto que esse dispositivo exige que a conduta sob análise vise a dominação de mercados, a eliminação da

\footnotetext{
${ }^{200}$ SHIEBER, Benjamin M. Op. cit., pp. 81/82. Ainda que o autor tenha tecido comentários a respeito da Lei $\mathrm{n}^{\circ} 4.137 / 62$, o raciocínio a ser realizado é o mesmo.

${ }^{201}$ De acordo com essa regra, o simples fato de um agente econômico praticar uma conduta definida como infração à ordem concorrencial já é suficiente para configurar o ilícito, independentemente da intenção.

202 BENJAMIN M. SHIEBER destaca que "[...] o sentido da regra da razão não pode ser unitário. O que é razoável para ajustes ou acordos entre empresas é diferente do que é razoável na compra do acervo de uma empresa por outra, e as considerações que devem condicionar a razoabilidade destes atos são diferentes das considerações em torno da criação de dificuldades à formação ou ao funcionamento de uma empresa." (Op. cit., p. 82).

${ }^{203}$ HOVENKAMP, Herbert. Federal antitrust policy - the law of competition and its practice. P. 170.

${ }^{204}$ FORGIONI, Paula A. Op. cit., p. 210.
} 
concorrência ou o aumento arbitrário de lucros para a configuração do abuso do poder econômico. $^{205}$

Nessa ordem de ideias, a Resolução do CADE $n^{\circ} 20 / 1999,{ }^{206}$ que trata das definições e classificações das práticas restritivas horizontais e verticais, assim registrou acerca dos critérios para sua análise:

\begin{abstract}
"A análise de condutas anticoncorrenciais exige exame criterioso dos efeitos das diferentes condutas sobre os mercados à luz dos artigos 20 e 21 da Lei 8884/94. As experiências nacional e internacional revelam a necessidade de se levar em conta o contexto específico em que cada prática ocorre e sua razoabilidade econômica. Assim, é preciso considerar não apenas os custos decorrentes do impacto, mas também o conjunto de eventuais benefícios dela decorrentes de forma a apurar seus efeitos líquidos sobre o mercado e o consumidor. (...)

O principal pressuposto, a ser verificado preliminarmente pela análise, é que condutas prejudiciais à concorrência, e não apenas a concorrente(s), em geral, requerem a pré-existência, a alavancagem de um mercado para outro ou a busca de posição dominante no mercado relevante por parte de quem a pratica.

Aplicando-se o princípio da razoabilidade, esses requisitos constituem condições necessárias, mas não suficientes, para considerar uma conduta prejudicial à concorrência. Para tanto é preciso avaliar seus efeitos anticompetitivos e ainda ponderá-los vis-à-vis seus possíveis benefícios ('eficiências') compensatórios." (grifos no original)
\end{abstract}

A previsão das condutas anticoncorrenciais pela Lei $n^{\circ} 8.884 / 94$ - que manteve a mesma linha de disciplina da repressão antitruste que se encontrava na Lei $n^{\circ}$ 4.137/62 assume esta razoabilidade, porquanto sua ilicitude somente se configura pela conjunção necessária dos artigos 20 e $21 .^{207}$

\footnotetext{
205 Também adotando posicionamento favorável à aplicação da regra da razão na legislação concorrencial nacional, cf. MAURO GRINBERG em O CADE e a regra da razão. No mesmo sentido, ROSO, Jayme Vita. Novos apontamentos à lei antitruste brasileira. P. 31 .

${ }^{206}$ Esta Resolução foi parcialmente revogada pela Resolução do CADE no 45, de 28 de março de 2007.

207 “[...] Art. 20. Constituem infração da ordem econômica, independentemente de culpa, os atos sob qualquer forma manifestados, que tenham por objeto ou possam produzir os seguintes efeitos, ainda que não sejam alcançados:

I - limitar, falsear ou de qualquer forma prejudicar a livre concorrência ou a livre iniciativa;
} 
II - dominar mercado relevante de bens ou serviços;

III - aumentar arbitrariamente os lucros;

IV-exercer de forma abusiva posição dominante.

$\S 1^{\circ}$ A conquista de mercado resultante de processo natural fundado na maior eficiência de agente econômico em relação a seus competidores não caracteriza o ilícito previsto no inciso II.

$\S 2^{\circ}$ Ocorre posição dominante quando uma empresa ou grupo de empresas controla parcela substancial de mercado relevante, como fornecedor, intermediário, adquirente ou financiador de um produto, serviço ou tecnologia a ele relativa.

$\S 3^{\circ}$ A posição dominante a que se refere o parágrafo anterior é presumida quando a empresa ou grupo de empresas controla $20 \%$ (vinte por cento) de mercado relevante, podendo este percentual ser alterado pelo CADE para setores específicos da economia.

Art. 21. As seguintes condutas, além de outras, na medida em que configurem hipótese prevista no art. 20 e seus incisos, caracterizam infração da ordem econômica;

I - fixar ou praticar, em acordo com concorrente, sob qualquer forma, preços e condições de venda de bens ou de prestação de serviços;

II - obter ou influenciar a adoção de conduta comercial uniforme ou concertada entre concorrentes;

III - dividir os mercados de serviços ou produtos, acabados ou semi-acabados, ou as fontes de abastecimento de matérias-primas ou produtos intermediários;

IV - limitar ou impedir o acesso de novas empresas ao mercado;

$V$ - criar dificuldades à constituição, ao funcionamento ou ao desenvolvimento de empresa concorrente ou de fornecedor, adquirente ou financiador de bens ou serviços;

VI - impedir o acesso de concorrente às fontes de insumo, matérias-primas, equipamentos ou tecnologia, bem como aos canais de distribuição;

VII - exigir ou conceder exclusividade para divulgação de publicidade nos meios de comunicação de massa; VIII - combinar previamente preços ou ajustar vantagens na concorrência pública ou administrativa;

$I X$ - utilizar meios enganosos para provocar a oscilação de preços de terceiros;

$X$ - regular mercados de bens ou serviços, estabelecendo acordos para limitar ou controlar a pesquisa e o desenvolvimento tecnológico, a produção de bens ou prestação de serviços, ou para dificultar investimentos destinados à produção de bens ou serviços ou à sua distribuição;

$X I$ - impor, no comércio de bens ou serviços, a distribuidores, varejistas e representantes, preços de revenda, descontos, condições de pagamento, quantidades mínimas ou máximas, margem de lucro ou quaisquer outras condições de comercialização relativos a negócios destes com terceiros;

XII - discriminar adquirentes ou fornecedores de bens ou serviços por meio da fixação diferenciada de preços, ou de condições operacionais de venda ou prestação de serviços;

XIII - recusar a venda de bens ou a prestação de serviços, dentro das condições de pagamento normais aos usos e costumes comerciais;

XIV - dificultar ou romper a continuidade ou desenvolvimento de relações comerciais de prazo indeterminado em razão de recusa da outra parte em submeter-se a cláusulas e condições comerciais injustificáveis ou anticoncorrenciais;

$X V$ - destruir, inutilizar ou açambarcar matérias-primas, produtos intermediários ou acabados, assim como destruir, inutilizar ou dificultar a operação de equipamentos destinados a produzi-los, distribuí-los ou transportá-los;

XVI - açambarcar ou impedir a exploração de direitos de propriedade industrial ou intelectual ou de tecnologia;

XVII - abandonar, fazer abandonar ou destruir lavouras ou plantações, sem justa causa comprovada;

XVIII - vender injustificadamente mercadoria abaixo do preço de custo;

$X I X$ - importar quaisquer bens abaixo do custo no país exportador, que não seja signatário dos códigos Antidumping e de subsídios do Gatt;

$X X$ - interromper ou reduzir em grande escala a produção, sem justa causa comprovada;

$X X I$ - cessar parcial ou totalmente as atividades da empresa sem justa causa comprovada;

XXII - reter bens de produção ou de consumo, exceto para garantir a cobertura dos custos de produção;

XXIII - subordinar a venda de um bem à aquisição de outro ou à utilização de um serviço, ou subordinar a prestação de um serviço à utilização de outro ou à aquisição de um bem;

XXIV - impor preços excessivos, ou aumentar sem justa causa o preço de bem ou serviço.

Parágrafo único. Na caracterização da imposição de preços excessivos ou do aumento injustificado de preços, além de outras circunstâncias econômicas e mercadológicas relevantes, considerar-se-á:

I - o preço do produto ou serviço, ou sua elevação, não justificados pelo comportamento do custo dos respectivos insumos, ou pela introdução de melhorias de qualidade; 
Desta feita, para que se configure uma infração à ordem concorrencial, é preciso a realização de uma das condutas previstas no artigo 21 da Lei $n^{\circ} 8.884 / 94$ - ou a elas semelhante, considerando tratar-se de rol exemplificativo e não taxativo - e a produção ou apenas sua possibilidade - de um dos efeitos previstos no artigo 20. De igual modo, o artigo 36 da Lei $n^{\circ}$ 12.529/11 preceitua que constituem infrações à ordem econômica quaisquer das condutas previstas no rol de seu $\S 3^{\circ}$, além de outras, desde que "[...] tenham por objeto ou possam produzir [...]" os efeitos mencionados no caput deste dispositivo.

Se uma das condutas previstas acima não for apta a prejudicar a livre concorrência, a dominar mercado relevante, a aumentar lucros arbitrariamente ou a exercer posição dominante de forma abusiva, não será considerada ilícita. Inclusive, a norma constitucional programadora da lei antitruste circunscreveu com clareza o conjunto das condutas empresariais suscetíveis de repressão legal, limitando àquelas que visem determinados efeitos lesivos às estruturas do livre mercado (artigo $173, \S 4^{\circ}$ ).

A causação de prejuízo à concorrência, ou à sua potencialidade, é imprescindível para a caracterização da infração. Não é outro o entendimento do CADE:

\footnotetext{
"Uma conduta anticoncorrencial é qualquer prática adotada por um agente econômico, que possa, ainda que potencialmente, causar danos à livre concorrência, mesmo que o infrator não tenha tido intenção de prejudicar o mercado. (...) $\mathrm{O}$ art. 21 da Lei $\mathrm{n}^{\mathrm{o}}$ 8.884/94 elenca algumas condutas que podem caracterizar infração à ordem econômica, na medida em que configurem hipótese de efeitos anticoncorrenciais prevista no art. 20. Como este último artigo da Lei estabelece que são infrações à ordem econômica os atos sob qualquer forma manifestados que tenham efeitos anticoncorrenciais, o art. 21 estabelece uma lista exemplificativa e não exaustiva de condutas que têm a possibilidade de causar tais danos à concorrência. Se tais condutas realmente terão esse efeito quando adotadas é uma questão a ser analisada caso a caso. $^{208}$
}

\footnotetext{
II - o preço de produto anteriormente produzido, quando se tratar de sucedâneo resultante de alterações não substanciais;

III - o preço de produtos e serviços similares, ou sua evolução, em mercados competitivos comparáveis;

IV - a existência de ajuste ou acordo, sob qualquer forma, que resulte em majoração do preço de bem ou serviço ou dos respectivos custos.”

${ }^{208}$ BRASIL. MINISTÉRIO DA JUSTIÇA. CADE. Guia Prático do CADE: a defesa da concorrência no Brasil.
} 
É exigida do intérprete e do aplicador da lei a observância a essa cautela, tendo em vista que a caracterização de condutas infracionais foi feita pela legislação infraconstitucional e pela Constituição Federal, de maneira que a repressão de qualquer tipo de comportamento que não configure abuso de poder econômico praticado com o intuito de produzir determinados efeitos será inconstitucional. ${ }^{209}$ Assim, delineados os instrumentos básicos para a definição de condutas anticoncorrenciais, analisar-se-ão os acordos entre agentes econômicos.

\subsection{Acordos entre Agentes Econômicos: Colusão}

Os ilícitos tendentes ao abuso do poder econômico podem ser exercidos mediante uma série de condutas, dentre as quais se situam os acordos firmados entre os agentes econômicos.

Pelo fato de permitir esse abuso, viabilizando a reprodução de condições monopolísticas, os acordos entre agentes econômicos são tradicionalmente regulamentados pelas legislações antitruste de todo o mundo.

Não procederam de maneira diversa os legisladores brasileiros, observando-se que o nosso sistema jurídico, ao tutelar a livre concorrência e reprimir o abuso do poder econômico, sempre determinou a ilicitude de acordos entre empresas que se apresentassem como nocivos à concorrência, em termos de objeto ou efeito provocado. ${ }^{210}$

A atual legislação antitruste determina expressamente que são considerados ilícitos os acordos entre os agentes econômicos que tenham por objeto ou possam produzir os seguintes efeitos:

- Limitar, falsear ou de qualquer forma prejudicar a livre concorrência ou a livre iniciativa.

- Dominar mercado relevante de bens ou serviços.

\footnotetext{
${ }^{209}$ COELHO, Fábio Ulhoa. Direito antitruste brasileiro: comentários à Lei no 8.884/94. P. 65.

${ }^{210}$ Acompanhar o seguinte histórico legislativo: Decreto-lei $\mathrm{n}^{\circ}$ 869, de 18 de novembro de 1938; Decreto-lei $\mathrm{n}^{\mathrm{o}}$ 7.666, de 22 de junho de 1945; Lei no 4.137, de 10 de setembro de 1962.
} 
- Aumentar arbitrariamente os lucros.

- $\quad$ Exercer de forma abusiva posição dominante. ${ }^{211}$

Nesta ambiência, vale salientar que, ao se estabelecer a expressão acordos entre agentes econômicos, não se pretende limitar a conduta somente a empresas, mas abranger quaisquer agentes que desempenhem uma função no mercado. ${ }^{212}$

Tendo em vista o mercado em que atuam os agentes econômicos celebrantes e os efeitos provocados pelos acordos, a doutrina os classifica em duas espécies, quais sejam os acordos horizontais e os verticais. Os primeiros, em suma, caracterizam-se pelo fato de envolver agentes econômicos que atuam em um mesmo mercado relevante (geográfico e material), encontrando-se em direta relação de concorrência. Os últimos disciplinam relações entre agentes econômicos que atuam em mercados relevantes diferentes, por diversas vezes complementares, como um acordo firmado entre fabricante e distribuidora. $^{213}$

A seguir, passar-se-á a tratar de cada uma dessas espécies de colusão.

\subsubsection{Colusão vertical}

Os chamados acordos verticais envolvem agentes que atuam em etapas diversas de uma mesma cadeia de comercialização, constituindo uma alternativa ao processo de concentração de empresas, uma vez que cada um dos agentes mantém isolado seu centro de poder, ao contrário do que ocorre na concentração, em que há uma perda de autonomia. $^{214}$

De toda a sorte, no entender de PAula A. Forgioni, a atuação conjunta das empresas causará nos mercados envolvidos praticamente os mesmos efeitos que

\footnotetext{
${ }^{211}$ Artigo 20, incisos I, II, III e IV, da Lei no $8.884 / 94$. Estes efeitos também estão previstos nos incisos I a IV do caput do artigo 36, da Lei ${ }^{\circ} 12.529 / 11$.

${ }^{212}$ Artigo 15 , da Lei ${ }^{\circ} 8.884 / 94$.

${ }^{213}$ Cf. FORGIONI, Paula A. Op. cit., pp. 323/324.

${ }^{214}$ O Anexo I da Resolução do CADE no 20, de 09 de junho de 1999, assim define as práticas restritivas verticais: “[...] são restrições impostas por produtores/ofertantes de bens ou serviços em determinado mercado ('de origem') sobre mercados relacionados verticalmente - a 'montante' ou a 'jusante' - ao longo da cadeia produtiva (mercado 'alvo')."
} 
decorreriam de uma prática concentracionista. ${ }^{215}$ Nessa espécie de prática restritiva, os efeitos concorrenciais podem ser produzidos nos seguintes mercados:

- $\quad$ No mercado relevante em que atua o produtor do bem ou serviço.

- No mercado relevante em que atua o distribuidor.

- No mercado do fornecedor de bens para o produtor. ${ }^{216}$

Mas se deve ter em conta que os efeitos sentidos no mercado podem ser considerados prejudiciais ou benéficos, a depender do mercado sob análise. Isto porque, esse tipo de acordo pode restringir a concorrência entre os agentes econômicos distribuidores de um mesmo bem ou serviço (intra brand competition) ${ }^{217} \mathrm{e}$, ao mesmo tempo, estimular a concorrência no mercado relevante em que atua o produtor (inter brand competition).

Grande parte da doutrina entende vantajosa a colusão vertical por trazer benefícios à concorrência, tais como:

- Viabilização de economias de escala mediante a redução de custos na distribuição.

- $\quad$ Facilitação da entrada de novos agentes econômicos no mercado de distribuição, em razão do retorno do investimento utilizado.

- Impedimento de free riders.

- Inibição da concentração de distribuidores.

- $\quad$ Permissão para a preservação da imagem do produto. ${ }^{218}$

Conforme entendimento esposado pelo CADE, as práticas restritivas verticais são anticompetitivas quando implicam a criação de mecanismos de exclusão dos concorrentes,

${ }^{215}$ FORGIONI, Paula A. Op. cit., P. 343.

${ }^{216}$ Cf. FORGIONI, Paula A. Idem, p. 344.

${ }^{217} \mathrm{Na}$ realidade, a preocupação que assola os doutrinadores reside nos efeitos horizontais negativos que essas práticas possam provocar. As restrições verticais geram efeitos prejudiciais quando visam aumentar barreiras à entrada em um mercado, levam à expulsão de firmas concorrentes ou suprimem obstáculos à formação de cartéis. (OLIVEIRA, Gesner; RODAS, João Grandino. Direito e economia da concorrência. P. 52).

${ }^{218}$ FORGIONI, Paula A. Op. cit., p. 344. 
seja aumentando as barreiras à entrada para competidores potenciais, seja elevando os custos dos competidores efetivos. Isto acontece também quando aumenta a probabilidade de exercício coordenado de poder de mercado dos produtores, fornecedores ou distribuidores e quando da criação de mecanismos que permitem a superação de obstáculos à coordenação que de outra forma existiriam. ${ }^{219}$

É oportuno proceder-se à análise caso a caso para se aferir a licitude do acordo vertical, examinando, especificamente, o mercado relevante envolvido, os benefícios trazidos para os demais concorrentes e para os consumidores e o tipo de produto comercializado.

Para HovenKAMP, a melhor maneira de se identificar restrições verticais anticompetitivas é

“[...] descobrir porque os fornecedores as realizam. Como premissa básica, um fornecedor fará tais restrições somente se elas forem lucrativas - ou seja, se o fornecedor puder ganhar mais com a restrição do que sem ela. Restrições poderiam ser lucrativas por um de dois motivos:

(1) porque aumentam a eficiência do sistema de distribuição e portanto auxiliam o fornecedor a reduzir seus custos;

(2) porque aumentam o poder de mercado do fornecedor e o capacitam a ganhar lucros de monopólio.

Uma política antitruste que vise maximizar o bem estar dos consumidores tentaria aprovar restrições que tivessem o primeiro efeito, e condenar aquelas que tivessem o segundo efeito.

$(\ldots)$

Infelizmente, não é sempre fácil olhar para uma restrição vertical particular e determinar porque um fornecedor a realiza e quais poderiam ser os seus efeitos. Mas existem alguns fatores que sugerem se há potencial anticompetitivo. Se nenhum desses fatores estiver presente, pode-se assumir que as restrições não são prejudiciais." 220

\footnotetext{
${ }^{219}$ Cf. Anexo I da Resolução do CADE no 20, de 19 de junho de 1999.

220 "The best way to determine when vertical restrictions are anticompetitive and ought to be condemned under the antitrust laws is to figure out why suppliers use them. As a basic premise, a supplier will use such restrictions only if they are profitable - that is, if the supplier can earn more with the restrictions than without them. Restrictions could be profitable for one of two reasons:
} 
Quanto aos tipos de acordos verticais existentes no mercado, a doutrina, em sua maioria, identifica quatro principais, quais sejam:

- Determinação dos preços de revenda.

- $\quad$ Divisão de mercado.

- $\quad$ Exclusividade.

- $\quad$ Venda casada. ${ }^{221}$

No primeiro caso (Resale Price Maintenance - RPM), o produtor estabelece os preços mínimo e máximo ou fixo a serem praticados pelos distribuidores/revendedores. A neutralização da concorrência torna-se evidente, pois é eliminada qualquer possibilidade de variação dos preços praticados. Em geral, a fixação de preços de revenda leva à diminuição da concorrência intramarca e ao aumento da concorrência intermarca.

Na divisão de mercados, atribui-se a cada um dos distribuidores uma parte do mercado, de modo que passam a atuar como verdadeiros monopolistas na parcela que lhes cabe. São estabelecidas limitações quanto à área de atuação desses agentes, restringindo a concorrência e a entrada em diferentes regiões. Tal prática pode ter como pontos positivos possíveis ganhos de escala na distribuição. ${ }^{222}$

(1) because they increase the efficiency of the distribution system and thus help the supplier lower its costs;

(2) because they increase the supplier's market power and enable it to earn monopoly profits.

An antitrust policy that attempts to maximize the welfare of consumers would try to approve restrictions that had the first effect, and condemn those that had the second effect. (...) Unfortunately, it is not always easy to look at a particular vertical restriction and determine why a supplier uses it and what its effects might be. But there are a few factors that suggest anticompetitive potential. If none of these factors is present, we can assume that the restrictions are harmless." (HOVENKAMP, Herbert. Op. cit., pp. 175/176).

${ }^{221}$ GESNER OLIVEIRA e JOÃo GRANDINO RODAS dividem as restrições verticais em três categorias:

"A primeira contém as restrições de preços que envolvem a fixação do preço de revenda pelo produtor. Assim, o distribuidor pode ser obrigado a respeitar um preço máximo quando se quer garantir uma maior penetração do produto ou a um preço mínimo quando se quer assegurar um determinado posicionamento do produto no mercado. Também é comum a divulgação de tabelas de sugestão de preços de forma a fornecer um parâmetro de comparação entre o que o fabricante recomenda e o que o consumidor paga no varejo.

A segunda categoria inclui as restrições territoriais como a delimitação de áreas de exclusividade para a atuação de um revendedor ou para o fornecimento do produto. A terceira categoria compreende restrições aos tipos de clientes que podem ser atendidos. Somem-se, por fim, comportamentos que o leitor deve observar diariamente, como os de discriminação de preços e o de venda casada." (Direito e economia da concorrência. Pp. 49/50).

${ }^{222}$ Idem, ibidem, p. 53. 
É inegável que tal prática facilite comportamentos colusivos e tendentes à formação de cartéis entre os produtores/distribuidores e a elevação unilateral do poder de mercado de um produtor. Além disso, elevam os custos de entrada em mercados geográficos contratualmente delimitados quando a extensão do mercado não acobertado pelo contrato não for economicamente atrativa aos novos distribuidores/revendedores.

Os acordos de exclusividade acontecem quando os compradores de determinado bem ou serviço se comprometem a adquiri-lo com exclusividade de determinado vendedor (ou vice-versa), havendo proibição da comercialização com os demais. Esta prática pode trazer benefícios com a diminuição de custos de transação, entretanto pode ser prejudicial na medida em que pode levar a um aumento de barreiras à entrada.

A venda casada é o exemplo mais típico de negociação compulsória, pois consiste na obrigatoriedade da aquisição de outros bens de um mesmo produtor que não aqueles originalmente desejados. No entanto, a venda casada não é só aquela em que é indispensável a compra dos dois produtos em conjunto. Ela também existe quando o preço cobrado pelo produto vendido separadamente não corresponde nem aproximadamente ao acréscimo de custo provocado ao vendedor pela separação dos produtos, configurando-se abusivo.

Desta maneira, o consumidor ou distribuidor sente-se na obrigação de comprar os produtos em conjunto para evitar o prejuízo decorrente da compra separada do único produto que lhe interessa. Atente-se ao fato de que a inexistência de um mercado separado para o produto casado conduz à inexistência de ilícito, pois a venda casada passa a ser natural e não coercitiva. ${ }^{223}$

FÁBio UlhoA CoElHo observa que

“[...] essa prática pode estar ligada à conquista de certo mercado, a partir do domínio já consolidado em outro. É o que se denomina teoria da alavanca, que tenta explicar como se processa essa ampliação da dominação econômica. Valendo-se de operações casadas, o empresário que domina a produção pode,

${ }^{223}$ SALOMÃO FILHO, Calixto. Direito concorrencial: as condutas. P. 226. 
inclusive, estender o seu domínio para o setor de distribuição, segundo o

ensinamento de Francesco Denozza (1998:101/110)." 224

Sobre o tema, trata o Anexo I da Resolução do CADE nº 20/1999, acrescentando ainda outros dois tipos de acordos:

- $\quad$ Recusa de negociação por parte de compradores e fornecedores.

- Discriminação de preços. ${ }^{225}$

${ }^{224}$ COELHO, Fábio Ulhoa. Direito antitruste brasileiro: comentários à Lei no ${ }^{\circ}$ 8.884/94. P. 84.

${ }^{225}$ A respeito de cada uma dessas espécies de práticas restritivas verticais, o ato administrativo consigna: "[...] 4. Recusa de negociação: o fornecedor ou comprador, ou conjunto de fornecedores ou compradores, de determinado bem ou serviço estabelece unilateralmente as condições em que se dispõe a negociá-lo, em geral a um distribuidor/revendedor ou fornecedor, eventualmente constituindo uma rede própria de distribuição/revenda ou de fornecimento.

Os efeitos anticompetitivos potenciais estão relacionados principalmente ao 'bloqueio' dos elou o aumento das barreiras à entrada nos canais de distribuição ou fornecimento, como no item anterior (incluindo possível aumento de custos de rivais), bem como os efeitos relacionados aos serviços pós-venda indicados no item 2 acima. As possíveis eficiências econômicas são essencialmente as mesmas do item anterior. Em geral, esta prática é utilizada em conjunto com outras práticas verticais anticompetitivas, tais como acordos de exclusividade ou fixação de preços de revenda, como forma de retaliação contra distribuidores/fornecedores relutantes em aderir à prática anticompetitiva.

Quando a prática é conduzida por controlador de infra estrutura essencial requer exame mais específico de seus efeitos sobre a concorrência. (...)

6. Discriminação de preços: o produtor utiliza seu poder de mercado para fixar preços diferentes para o mesmo produto/serviço, discriminando entre compradores, individualmente ou em grupos, de forma a se apropriar de parcela do excedente do consumidor e assim elevar seus lucros.

Esta prática, amplamente disseminada nas economias modernas, não é intrinsecamente anticompetitiva, na medida em que, embora aumentando os lucros do produtor, pode não afetar o bem estar dos consumidores ao não restringir, ou até ao aumentar, o volume de transações no mercado. A análise específica se torna particularmente relevante neste caso, especialmente pela variedade de formas em que pode ocorrer a discriminação de preços.

Em serviços de utilidade pública, a discriminação de preços reflete, com freqüência, a presença de categorias de consumidores com níveis muito díspares de consumo; diante de elevadas economias de escala, torna-se em geral eficiente cobrar menos de consumidores de volumes maiores. Na mesma direção, quando o custo marginal de fornecimento de um serviço aumenta significativamente em certos intervalos de tempos, comumente denominados 'períodos de pico', o estabelecimento de preços diferenciados constitui prática eficiente.

Quando uma empresa discrimina entre dois ou mais grupos de consumidores com curvas de demanda com diferente elasticidade, a análise deve ser cuidadosa, pois o impacto de tal prática sobre o bem estar depende de vários fatores a respeito dos quais a autoridade nem sempre dispõe de informação segura.

Em certos casos, a discriminação de preços pode estar indicando uma variante de recusa de vendas ou de venda casada; sob essas formas indiretas, é uma prática relativamente freqüente em setores regulados abertos à concorrência.

Em situações em que uma empresa tem controle parcial ou total sobre uma rede ou infra estrutura essencial, a discriminação de preços pode servir para elevar o custo do concorrente, com efeitos nocivos à livre concorrência." (Anexo I da Resolução do CADE nº 20, de 09 de junho de 1999). 


\subsubsection{Colusão horizontal: os cartéis}

De outra banda, a colusão horizontal é considerada de maior potencial de dano ao mercado. Isto porque são ações entre concorrentes que deveriam, em tese, concorrer no mercado e não cooperar entre si. $^{226}$

As práticas restritivas horizontais consistem na tentativa de reduzir ou eliminar a concorrência em um mesmo mercado, “[...] seja estabelecendo acordos entre concorrentes no mesmo mercado relevante com respeito a preços ou outras condições, seja praticando preços predatórios [...]", ${ }^{227}$ o que se afigura, de certa forma, uma reação natural dos agentes. Isto porque a concorrência prejudica os concorrentes, na medida em que leva o empresário a investir mais para manter-se no mercado, a ter maior cautela com a qualidade de seu produto e a abaixar o preço para competir com seus concorrentes. Assim, a busca pela neutralização da concorrência é esperada mediante a conquista de posição monopolística e/ou a realização de acordos.

Conforme o Anexo I da Resolução do CADE n 20/1999, essas práticas visam “[...] de imediato, ou no futuro, em conjunto ou individualmente, o aumento de poder de mercado ou a criação de condições necessárias para exercê-lo com maior facilidade [...]" e pressupõem "[...] a existência ou a busca de poder de mercado sobre o mercado relevante." Este ato normativo emanado pelo CADE menciona, sobretudo, quais as situações mais comuns de práticas restritivas horizontais no entender daquela autarquia federal:

"1. Cartéis: acordos explícitos ou tácitos entre concorrentes do mesmo mercado, envolvendo parte substancial do mercado relevante, em torno de itens como preços, quotas de produção e distribuição e divisão territorial, na tentativa de aumentar preços e lucros conjuntamente para níveis mais próximos dos de monopólio.

Fatores estruturais podem favorecer a formação de cartéis: alto grau de concentração do mercado, existência de barreiras à entrada de novos competidores, homogeneidade de produtos e de custos, e condições estáveis e de demanda.

\footnotetext{
${ }^{226}$ OLIVEIRA, Gesner; RODAS, João Grandino. Direito e economia da concorrência. P. 40.
}

${ }^{227}$ Anexo I da Resolução do CADE n ${ }^{\circ} 20$, de 09 de junho de 1999. 
2. Outros acordos entre empresas: restrições horizontais que envolvam apenas parte do mercado relevante e/ou esforços conjuntos temporários voltados a buscar maior eficiência, especialmente produtiva ou tecnológica.

Estes exigem avaliação mais complexa, tanto por terem efeitos anticompetitivos possivelmente menores que os cartéis, quanto pela necessidade de avaliar eventuais eficiências econômicas, requerendo uma aplicação mais ponderada do princípio da razoabilidade.

3. Ilícitos de Associações profissionais: quaisquer práticas que limitem injustificadamente a concorrência entre os profissionais, principalmente mediante conduta acertada de preços.

4. Preços predatórios: prática deliberada de preços abaixo do custo variável médio, visando eliminar concorrentes para, em momento posterior, poder praticar preços e lucros mais próximos do nível monopolista.

O exame dessa prática requer análise detalhada das condições efetivas de custos e do comportamento dos preços ao longo do tempo, para afastar a hipótese de práticas sazonais normais ou de outras políticas comerciais da empresa, além da análise de comportamento estratégico, avaliando-se as condições objetivas de ganhos potencialmente extraordinários posteriores suficientemente elevados e capazes de compensar as perdas decorrentes das vendas abaixo do custo." (grifos no original)

A mais abalizada doutrina preceitua que esses acordos celebrados entre empresas concorrentes e que visam a neutralização da concorrência são os denominados cartéis, ${ }^{228}$ caracterizados pelo ajuste entre agentes, que conservam, apesar desse acordo, suas independências administrativa e financeira, com a finalidade de eliminar ou diminuir a concorrência, conseguindo o monopólio em determinado setor da atividade econômica. ${ }^{229}$

\title{
Para RODOLFO TIGRE MAIA,
}

\begin{abstract}
"Este termo designa o arranjo efetuado entre empresas concorrentes para limitar ou eliminar a competição entre elas, que se manifesta através da divisão do mercado ou da fixação conjunta de preços, ou da divisão de
\end{abstract}

\footnotetext{
${ }^{228} \mathrm{Na}$ Ciência Econômica, entende-se por cartel o "[...] grupo de empresas independentes que formalizam um acordo para sua atuação coordenada, como vistas a interesses comuns. O tipo mais freqüente de cartel é o de empresas que produzem artigos semelhantes de forma a constituir um monopólio de mercado." (SANDRONI, Paulo (org. e superv.). Novíssimo dicionário de economia. P. 84).

229 BRANCO, Nelson de Andrade; BARRETO, Celso de Albuquerque. Repressão ao abuso do poder econômico. P. 30 .
} 
clientelas ou da limitação da produção etc. Isto sempre é feito com o escopo precípuo de organizar as condições da participação das empresas cartelizadas no âmbito do mercado de modo a que estas logrem atingir um controle do mesmo que lhes possibilite otimizar seus ganhos, para além do que ocorreria em uma situação normal de concorrência, e sem oferecer aos consumidores qualquer vantagem objetiva adicional.", 230

\title{
O conceito elaborado por EDUARDo MOLAN GABAN e JULIANA OLIVEIRA
}

DOMINGUES considera cartel, em sentido amplo, como

\begin{abstract}
"[...] a restrição e até a eliminação da concorrência entre um conjunto de empresas, com a finalidade de auferir lucros maiores. A estrutura de oferta vigente é fixada e as participações do mercado são mantidas. Com a ação coordenada, cada empresa tem condições de praticar preços e conseguir lucros maiores." 231
\end{abstract}

A tradicional definição de cartel é apresentada pela Lei de Defesa da Concorrência, em seu artigo 21: "[...] fixar ou praticar, em acordo com concorrente, sob qualquer forma, preços e condições de venda de bens e prestação de serviços.” 232

É imprescindível observar que não há que se falar em cartel como infração administrativa à luz da Lei $\mathrm{n}^{\mathrm{o}} 8.884 / 94$, se um acordo não restringe a livre concorrência ou não acarreta a incidência de qualquer um dos incisos do artigo 20 deste diploma legal. ${ }^{233,234}$

\footnotetext{
${ }^{230}$ MAIA, Rodolfo Tigre. Op. cit., p. 37.

${ }^{231}$ GABAN, Eduardo Molan; DOMINGUES, Juliana Oliveira. Direito antitruste: o combate a cartéis. P. 164.

${ }^{232}$ Com a nova legislação antitruste, a definição de cartel vem apresentada pelo inciso I do $\S 3^{\circ}$ do artigo 36 :

"I - acordar, combinar, manipular ou ajustar com concorrente, sob qualquer forma:

a) os preços de bens ou serviços ofertados individualmente;

b) a produção ou a comercialização de uma quantidade restrita ou limitada de bens ou a prestação de um número, volume ou frequência restrita ou limitada de serviços;

c) a divisão de partes ou segmentos de um mercado atual ou potencial de bens ou serviços, mediante, dentre outros, a distribuição de clientes, fornecedores, regiões ou períodos;

d) preços, condições, vantagens ou abstenção em licitação pública; [...]”,

${ }^{233}$ É este também o entendimento do CADE (vide Processo Administrativo no 26, de 1971).

234 Eduardo Molan Gaban e Juliana Oliveira DOMingues destacam a importância dos efeitos produzidos, ou que possam ser produzidos, pelas condutas cartelizadoras: "Importa frisar, contudo, que há na Lei $n$. 8.884/94, precisamente em seu artigo 20, caput, dispositivo que necessita de ponderação em face do raciocínio ora exposto: trata-se do enunciado '(...) ou possam produzir os seguintes efeitos (...)'. Esse dispositivo traz, a priori, a idéia de que a mera possibilidade de geração de efeitos maléficos ao Mercado e à livre concorrência já ensejaria a ocorrência da infração, todavia, diante da lógica que edifica referido
} 
Vale lembrar que a orientação foi mantida na recém-publicada Lei n ${ }^{\circ}$ 12.529/11 (artigo 36, incisos I a IV do caput).

Assim, ausentes os efeitos previstos no artigo 20 da Lei $n^{\circ} 8.884 / 94$, figura perfeitamente possível que se verifique algum acordo previsto no artigo 21, do mesmo diploma legal, sem que haja infração à ordem econômica. ${ }^{235}$

Algumas justificativas são, ainda, apresentadas para os cartéis, alegando-se sua licitude. Argumenta-se que, sobretudo em tempos de crise, os acordos entre concorrentes representariam importante papel, pois sua ausência causaria maiores prejuízos à economia. Uma outra explicação repousa na ideia segundo a qual os cartéis visam eliminar a concorrência ruinosa (cutthroat competition), predatória, destrutiva, que seria prejudicial não somente aos agentes econômicos, mas para toda a coletividade. Em uma economia ainda não tão forte, a união dos concorrentes poderia ser a melhor opção para a competição em nível internacional. ${ }^{236}$

Na mesma linha, o Anexo I da Resolução do CADE nº 20/1999 consigna que, em diferentes graus, as práticas restritivas horizontais podem até gerar benefícios em termos

diploma legal e a própria tutela antitruste, é necessário observar esse mandamento mais sob a ótica do sistema do discurso jurídico-positivo do que sob a ótica de sua estrita literalidade.

Isso porque a consideração de que a mera possibilidade ensejaria a configuração da infração e, consequentemente, a necessidade da condenação da prática por parte das autoridades de defesa da concorrência equivaleria a dizer que todos os agentes econômicos investigados portadores de poder de Mercado estariam fadados à condenação, pois que as práticas investigadas sempre, à luz do raciocínio estático edificado sobre o universo das relações triádicas de comparação (universo das possibilidades lógicas), teriam a possibilidade da geração de efeitos avessos à Lei e, logo, à Constituição.

Todavia, isto não condiz com o espírito da Lei n. 8.884/94, sobretudo quando avaliadas sua lógica de operação deôntica e sua função na concretização dos princípios constitucionais da livre iniciativa e da livre concorrência, conforme já aventado neste estudo.

Desse modo, antes de ser tomado em sua letra e tão-somente ela, o enunciado contido no artigo 20, caput, deve sofrer a calibração necessária tendo em vista a consecução das finalidades do diploma antitruste, de modo que deve ser interpretado numa perspectiva dinâmica que não se restringe ao universo das relações triádicas de comparação, mas se estende ao universo das relações triádicas de desempenho e ao universo das relações triádicas de pensamento, sobre o qual deve ser construída a norma de decisão.

Em outras palavras, quando se fala em '(...) ou possam produzir os seguintes efeitos (...)' deve-se entender que está se falando numa perspectiva dinâmica, em probabilidade majoritária de ocorrência e não mera possibilidade lógica de ocorrência, sob pena de se verter à desordem todo o mecanismo de raciocínio que edifica a lógica do antitruste acolhida pela Lei n. 8.884/94." (GABAN, Eduardo Molan; DOMINGUES, Juliana Oliveira. Direito antitruste: o combate a cartéis. Pp. 171/172). jjjjjjj

${ }^{235}$ PAUla A. Forgioni cita, à guisa de exemplo, "[...] o típico caso de agentes econômicos que se unem em conluio, sob o manto da 'associação de classe', ou 'associações buscando a qualidade do produto'. Como é cediço, nada há de ilícito na associação de agentes econômicos, sendo essa prática, inclusive, assegurada pela Constituição Federal. Não obstante, a partir do momento em que a associação é um instrumento (ou um disfarce) adotado pelos agentes econômicos para viabilizar uma prática anticompetitiva (ou seja, desde que haja a incidência de qualquer dos incisos do art. 20), esta haverá de ser considerada abusiva.” (Op. cit., p. 328).

${ }^{236}$ Idem, ibidem, p. 329. 
de bem-estar ao mercado (eficiências econômicas), de modo que "[...] é preciso ponderar tais efeitos vis-à-vis os potenciais impactos anticompetitivos da conduta (...) uma prática restritiva somente poderá gerar eficiências líquidas caso as eficiências econômicas dela derivadas compensem seus efeitos anticompetitivos." 237

Abre-se aqui um parêntesis para registrar as orientações expostas por GESNER OLIVEIRA e JOÃo GRANDINO RODAS, a fim de identificar acordos horizontais permitidos pela legislação. Para eles, é necessário verificar se:

- $\quad$ as empresas envolvidas possuem poder de mercado, isto é, se conseguem ou não influenciar nos preços e nas quantidades vendidas, causando dano à concorrência;

- $\quad$ o objeto da cooperação poderia induzir ou facilitar a formação de um cartel;

- a prática constatada influencia a adoção de conduta comercial uniforme ou concertada entre concorrentes. $^{238}$

Insta destacar que diversos são os tipos de cartéis existentes no mercado. Dentre eles, pela relevância que assumem, é primordial a menção aos cartéis de preços, que constituem acordos tendentes a fixar preços, abaixo ou acima daqueles de mercado. A depender da estrutura do mercado relevante em que atuam os partícipes, tem-se dois tipos de acordos: aqueles celebrados entre agentes que mantêm poder econômico semelhante e os firmados quando há um agente econômico com poder suficiente para sujeitar os demais à sua própria política de preços (os denominados acordos de price leadership). ${ }^{239}$

Os acordos travados entre agentes econômicos em posição de igualdade ocorrem quando não há no mercado agente econômico algum com poder suficiente para impor sua política de preços. ${ }^{240}$ Nesta espécie de acordo, tem-se em vista eliminar os efeitos da

\footnotetext{
${ }^{237}$ Anexo I da Resolução do CADE $n^{\circ}$ 20, de 09 de junho de 1999.

${ }^{238}$ OLIVEIRA, Gesner; RODAS, João Grandino. Direito e economia da concorrência. P. 40.

${ }^{239}$ Há uma questão interessante que exsurge ao se analisar este tipo de acordo horizontal. Nem sempre a prática do price leadership configura ato colusivo, sendo possível a uniformização de preços através de um mero abuso de posição dominante, de maneira que um agente impõe-se como líder na determinação dos preços a serem praticados. Este pode estabelecer mecanismos coercitivos para obrigar os demais agentes a seguirem seus preços, seja pela força, seja pela intimidação aplicada. O mais curioso é que o acordo de price leadership pode surgir também de um processo normal de concorrência, havendo uma uniformização de preços decorrente das chamadas forças normais de mercado.

${ }^{240}$ Este é o clássico exemplo dos acordos travados entre as ferrovias norte-americanas anteriormente à promulgação do Sherman Act.
} 
concorrência sobre o preço de produtos ou serviços, de sorte que as alterações não decorrerão de oscilações de oferta e procura.

Nesses casos, os participantes são naturalmente compelidos a trair o cartel, praticando a venda de seus produtos por um valor mais barato, de modo que iniciam uma verdadeira guerra de preços. Por esse motivo, não raras vezes se atesta que quanto maior o número de empresas em determinado mercado, mais difícil será a sua cartelização (maiores as possibilidades de algum deles quebrar o cartel). ${ }^{241}$

Além dessa frequente instabilidade, outros problemas envolvem este tipo de cartel: se os preços fixados foram muito altos, potenciais concorrentes serão atraídos e encorajados a ingressar naquele mercado relevante. Assim, sem barreiras à entrada, não será viável a sobrevivência dos participantes do cartel.

Já nos acordos de price leadership, os agentes econômicos seguem o preço praticado pela empresa que detém poder dominante naquele mercado. Nesses casos, nem sempre existe a prática de ato colusivo, sendo comum que a responsabilização não recaia sobre todos os agentes que fazem incidir o preço uniforme. Isto porque, pode-se estar diante de um abuso de posição dominante. Um dos agentes econômicos, único apto a praticar preços diversos, impõe-se como líder em relação aos concorrentes, determinando os preços a serem praticados. Nesses casos, é recorrente a utilização de mecanismos coercitivos (força ou intimidação) para obrigar pequenas empresas a seguirem os preços impostos.

\subsubsection{Espécies de acordos}

Como já visto, a colusão horizontal pressupõe a existência de um acordo ilícito de vontades entre agentes econômicos. Este acordo pode ser expresso ou tácito, a depender da evidência de seus atos. Este último pode ser caracterizado mais facilmente por um comportamento paralelo intencional.

Vale mencionar que os acordos expressos e tácitos estão previstos na Lei $n^{\circ}$ 8.884/94, onde, em seu artigo 21, o legislador assim dispôs:

${ }^{241}$ FORGIONI, Paula A. Op. cit., p. 334. 


\begin{abstract}
"As seguintes condutas, além de outras, na medida em que configurem hipótese prevista no art. 20 e seus incisos, caracterizam infração da ordem econômica: I - fixar ou praticar, em acordo de concorrentes, sob qualquer forma, preços e condições de venda de bens ou de prestação de serviços.” (grifos nossos)
\end{abstract}

Ao mencionar os termos fixar ou praticar, determina a lei que tanto fixar, portanto em acordo expresso, ou praticar, ou seja, perpetrar ainda que de maneira tácita, preços e condições de venda, caracteriza infração contra a ordem econômica. ${ }^{242}$

A seguir, ver-se-á o exato significado de acordo expresso e tácito entre concorrentes.

\title{
3.3.2.1.1 Acordos Expressos
}

Eles são caracterizados pela sua durabilidade e estabilidade, ainda que relativa. Normalmente, nestes acordos há a possibilidade de se unificar ou permitir a previsão da política empresarial dos concorrentes. É comum a troca de informações entre os concorrentes acerca dos preços acertados.

Nesta espécie de acordo, “[...] o mais freqüente indício de acordo está no préanúncio de elevação de preços, feito geralmente pelo líder do cartel para que os demais o acompanhem.” 243

A ideia da durabilidade, essencial para a noção concorrencial de acordo, está presente na legislação concorrencial brasileira, que utiliza a expressão " [...] fixar preços, em acordo com concorrente [...]" (artigo 21, inciso I da Lei $n^{\circ}$ 8.884/94). Somente com a demonstração dessa durabilidade, pode-se estar certo de que o vínculo criado tem relevância para o Direito Concorrencial. Na opinião de CALIXTO SALOMÃo FILHO,

“[...] prova importante é a existência de convergência expressa, verbal, ou escrita, de vontades, e não a forma como essas vontades se expressam. Daí a

\footnotetext{
242 Já a nova lei antitruste menciona as condutas de acordar, combinar, manipular ou ajustar (artigo $36, \S$ $3^{\circ}$, inciso I), o que pode ensejar novo posicionamento acerca do assunto.

${ }^{243}$ SALOMÃ̃ FILHO, Calixto. Direito concorrencial: as condutas. P. 264.
} 
razão da - por vezes caricatural - busca de provas fáticas de concerto de intenções em direito concorrencial, como encontros furtivos ou coisas do gênero." 244

Em virtude disso, as investigações de cartéis tem-se resumido tão somente à busca de prova de acordo. Evidentemente, nesse sentido, a disciplina só enfraquece, pois se torna restrita, passando a englobar apenas as hipóteses de acordo expresso e formalizado.

Infelizmente, para se compensar essa restrição e na busca de uma efetividade maior nas investigações, parte-se da premissa de que qualquer reunião entre concorrentes configura indício de prática anticoncorrencial. Os agentes passam a ser punidos pelo simples fato de se reunirem, havendo clara afronta ao direito constitucional de reunião (artigo $5^{\circ}$, inciso XVI da Carta Magna). ${ }^{245}$

Nessas circunstâncias, são adotados juízos preconceituosos em relação a associações comerciais que realizam reuniões entre seus afiliados, assim como a sindicatos de classe, sem levar em conta que há reuniões lícitas para discutir temas corriqueiros, como incentivos fiscais, novas tecnologias, questões referentes à importação e à exportação no setor etc.

\footnotetext{
${ }^{244}$ Idem, ibidem, p. 265.

${ }^{245}$ De acordo com José AFONSO DA SILVA: "A liberdade de reunião está prevista no art. $5^{o}$, XVI, da Constituição, nos termos seguintes: 'todos podem reunir-se pacificamente, sem armas, em locais abertos ao público, independentemente de autorização, desde que não frustrem outra reunião anteriormente convocada para o mesmo local, sendo apenas exigido prévio aviso à autoridade competente’.

Aí a liberdade de reunião está plena e eficazmente assegurada, não mais se exige lei que determine os casos em que será necessária a comunicação prévia à autoridade, bem como a designação, por esta, do local da reunião. Nem se autoriza mais a autoridade a intervir para manter a ordem, o que era utilizado para dificultar o exercício do arbitrio de autoridade. Agora apenas cabe um aviso, mero aviso, à autoridade que terá o dever, de ofício, de garantir a realização da reunião. Não tem a autoridade que designar local, sequer aconselhar outro local, salvo se comprovadamente já estiver ciente, por aviso insofismável, de que outra reunião já fora convocada para o mesmo lugar.

Reunião, aí, é qualquer agrupamento formado em certo momento com o objetivo comum de trocar idéias ou de receber manifestação de pensamento político, filosófico, religioso, científico ou artístico. Reunião, no correto dizer de Pontes de Miranda, 'é a aproximação - especialmente, considerada - de algumas ou muitas pessoas, com fim de informar-se, de esclarecer-se e de adotar opinião (deliberar, ainda que só no foro intimo)'. Não é propriamente um agrupamento organizado, como, às vezes, se diz, porque organização pressupõe acerto entre os componentes, estruturação interna, o que não se verifica na reunião. Nesta, o agrupamento, a aproximação, dá-se pela simples atração do objetivo comum, que sequer precisa ser definido. A mera curiosidade em face de acontecimentos não é suficiente para dar ao agrupamento o seu sentido de reunião. É que esta, se não pressupõe acordo prévio entre seus componentes, funda-se, ao menos, numa avocação prévia sob a direção de alguém ou de uma comissão. Só na existência dessa coordenação ou direção da reunião é que se encontra um ligeiro elemento organizativo. É isso também que demarca a reunião em relação aos aglomerados instantâneos ou outros agrupamentos. Não são reuniões, pois, nem os ajuntamentos ocasionais nem os ajuntamentos por força de ordens legais." (SILVA, José Afonso da. Op. cit., pp. 262/263, grifos do autor).
} 
Recentemente, foi elaborada pela Secretaria de Direito Econômico a Cartilha sobre combate a cartéis em sindicatos e associações, com o objetivo de "[...] informar empresas filiadas ou associadas, bem como sindicatos e associações de classe sobre como atuar em consonância com a Lei de Defesa da Concorrência [...].” Conforme suas orientações,

\begin{abstract}
"Os sindicatos e as associações de classe desempenham papel fundamental em nossa sociedade: reúnem indivíduos e empresas que comungam interesses semelhantes a fim de representá-los comercial, política ou socialmente. O papel de tais associações na economia moderna é amplamente reconhecido: suas atividades podem beneficiar seus membros e também contribuir para o aumento da eficiência do mercado.
\end{abstract}

Contudo, a despeito dos seus aspectos benéficos, os sindicatos e as associações - principalmente aqueles que congregam empresas concorrentes são expostos a risco não desprezível de se envolverem em práticas contrárias à concorrência e ao livre mercado. As recorrentes discussões entre as empresas associadas no âmbito dos sindicatos e das associações podem extrapolar as funções legítimas das entidades, permitindo que seus membros troquem informações comercialmente sensíveis, tais como preços, estratégias de mercado, quantidade produzida e clientes.

A troca desse tipo de informação pode caracterizar ilícitos previstos na Lei de Defesa da Concorrência (Lei n ${ }^{\circ}$ 8.884/94), além de crime, nos termos da Lei $\mathrm{n}^{\circ}$ 8.137/90. Com efeito, grande parte dos cartéis condenados pelo CADE de 1994 até 2009 contou com a participação ativa de sindicatos e associações.

Os sindicatos e as associações devem, portanto, ser cuidadosos e evitar condutas que possam atentar contra a livre concorrência." 246

Assim, aconselha-se o que segue:

\begin{abstract}
"Reuniões entre concorrentes em sedes de sindicatos e associações podem gerar preocupações concorrenciais. Tais encontros não devem tornar-se fórum para a discussão de temas comercialmente sensíveis, como preços, política de descontos, custos, clientes, alocação de mercado, participações em licitações, dados de produção, entre outros.
\end{abstract}

${ }^{246}$ BRASIL. MINISTÉRIO DA JUSTIÇA. SECRETARIA DE DIREITO ECONÔMICO. Cartilha sobre o
combate a cartéis em sindicatos e associações. P. 03 . 
Nesse sentido, é recomendável que os sindicatos e as associações tenham agendas públicas de reuniões, com temas claros. Além disso, devem ser elaboradas atas de tais reuniões que abordem a totalidade da discussão. É recomendável ainda que os sindicatos arquivem tais documentos com o intuito de demonstrar a licitude das discussões. Por fim, recomenda-se fortemente que os representantes de cada empresa nas reuniões não sejam funcionários do Departamento Comercial ou de Vendas da empresa e que os dirigentes dos sindicatos ou associação sejam independentes, afastando-se da direção empresarial." 247

Incontestável, essa equivocada interpretação a respeito das associações e sindicatos é bem difundida. A esse respeito, registra estudo do Banco Mundial e da Organização para a Cooperação e o Desenvolvimento Econômico (OCDE):

\begin{abstract}
“[...] as reuniões das associações comerciais podem também servir como um fórum para as ações dos cartéis, e as próprias associações podem ocasionalmente se envolver em atividades competitivas. $\mathrm{O}$ compartilhamento de informações relevantes à concorrência pode estimular ou apoiar uma colusão tácita ou explícita, e as associações comerciais estão geralmente situadas de forma ideal para facilitar esses intercâmbios contrários à concorrência." 248
\end{abstract}

Nesses casos, é basilar estabelecer-se um rígido limite entre o lícito e o ilícito, sendo relevante constatar a presença de um disfarce para práticas anticompetitivas a justificar uma investigação. Caso contrário, instaura-se uma verdadeira perseguição às associações, aos sindicatos e a todo o tipo de reunião, em claro desrespeito à Constituição Federal.

Frise-se que para a caracterização do cartel, deve-se ir além da prova do acordo, buscando-se outros elementos de comprovação da ilicitude da conduta, por exemplo, as características do conluio do qual se tem indícios. Além disso, a discussão jurídica sobre os acordos não pode se esgotar na questão de sua prova. Para ser relevante para o Direito Concorrencial, o acordo tem de ser qualificado pelo efeito que produz. Assim, uma simples

\footnotetext{
${ }^{247}$ Idem, ibidem, p. 15.

248 MOURA, Fabíola; BELTRAME, Priscila Akemi. Diretrizes para elaboração e implementação de política de defesa da concorrência. P. 94.
} 
discussão de preços entre agentes econômicos sem qualquer poder no mercado não gera qualquer risco para a concorrência. ${ }^{249}$

Não se dá o mesmo com os acordos tácitos. É o que será visto a seguir.

\subsection{Acordos Tácitos}

De início, é essencial consignar que nem toda prática de preços semelhantes é direcionada a restringir a concorrência. Isso pode significar, por exemplo, uma intensa concorrência entre os agentes econômicos e nada mais. A legislação brasileira de defesa da concorrência esclarece a questão ao prever, em seu artigo 21, inciso I, a prática de preços e condições de venda por meio de acordos entre concorrentes.

É usual, em um mercado com concorrência acirrada, que os agentes econômicos fixem seus preços entre um mínimo e um máximo muito próximos, em razão de estarem todos os concorrentes na mesma intensidade à pressão dos custos variáveis de produção, com reflexos em uma alteração de preços com valores aproximados e em um mesmo momento.

A movimentação comum de preços só pode ser considerada indício suficiente para comprovação de um acordo tácito quando for persistente em um só sentido e quando não é justificada por mudanças significativas e comuns nos custos dos participantes. Essa situação não se compatibiliza com um mercado competitivo, no qual é comum que os agentes econômicos abaixem seus preços, a fim de conquistar parte do mercado, sendo seguidos pelos seus concorrentes. ${ }^{250}$

A esse respeito, CALIXTO SALOMÃo FILHO destaca:

\footnotetext{
"Não por outra razão o Conselho Administrativo de Defesa Econômica (CADE) vem insistentemente arquivando processos em que há acusação de acordo de preços onde a prova é a proximidade - ou igualdade - de preços no mercado. O fundamento é exatamente a impossibilidade - econômica e
}

\footnotetext{
${ }^{249}$ O CADE, desde a vigência da lei de 1962, fixou entendimento no sentido de que somente se caracteriza um cartel quando o acordo entre agentes econômicos possa produzir efeitos anticompetitivos.

${ }^{250}$ SALOMÃO FILHO, Calixto. Regulação e concorrência (estudos e pareceres). P. 156.
} 
jurídica - de fazer qualquer inferência a partir simplesmente da proximidade dos preços praticados. Sobre este ponto há importante decisão do CADE, datada de 18.6.1997, no julgamento do PA 3/1991, envolvendo o Departamento de Abastecimento e Preços do Ministério da Economia, Fazenda e Planejamento (como representante) e as empresas Goodyear do Brasil - Produtos de Borracha Ltda., Pirelli Pneus S/A, Indústria de Pneumáticos Firestone Ltda. e Cia. de Pneumáticos Michelin Indústria e Comércio (representadas). Constou da ementa do julgamento: "Conduta uniforme - Prática concertada de preços - Setor oligopolizado - Pneumáticos - Insuficiência ao reconhecimento da infração - Controle governamental de preços". Segundo o entendimento do CADE, "o simples fato de o setor de pneus ser oligopolizado (formado por três ou quatro empresas) não é suficiente para caracterizar conduta uniforme ou concertada entre os concorrentes (...)” (J. I. G. Franceschini, Lei da Concorrência..., p. 313). Também no julgamento do PA 0.8000.014677/94-18 e da Averiguação Preliminar 08000.004493/97-00 o CADE decidiu pelo arquivamento dos mesmos, por entender que somente a constatação de preços semelhantes praticados pelas empresas não consistiria em indício suficiente a comprovar a colusão tácita destas, bem como a existência do cartel.” 251

Contudo, reforçam-se os indícios da formação de cartel tácito quando há modificações simultâneas nos preços, sem uma correspondente justificativa referente a um aumento nos custos de produção ou alteração de demanda.

Mister mencionar que para que haja um comportamento paralelo, é pré-requisito a presença de um sistema de informações que permita a cada agente econômico saber de imediato qual será o comportamento do outro. Outro elemento que pode apontar a existência de um comportamento paralelo é a reação imediata dos agentes econômicos aos movimentos dos demais. A rapidez de mudança de preços indica que não há pressões de demanda, mas sim um efetivo sistema de troca de informações.

No que tange aos requisitos estruturais, como já visto com relação aos acordos expressos, eles serão essenciais todas as vezes que o acordo não for capaz, por si só, de dar estabilidade e possibilidade de expansão ao acerto entre os concorrentes. Já para os acordos tácitos, só é possível presumir a possibilidade de produzir qualquer efeito a partir da

${ }^{251}$ Idem. Direito concorrencial: as condutas. P. 273. 
análise dos elementos estruturais. Nem mesmo a intenção pode ser aferida sem a presença desses requisitos.

E para a caracterização do ilícito não basta a existência do ato ou conduta. É imprescindível demonstrar que o ilícito tem como propósito dominar o mercado e, para tanto, deve evidenciar a possibilidade de, economicamente, produzir esse efeito.

Aliás, exige-se que exista um oligopólio, pois, nesse modelo, qualquer baixa de preços é imediatamente acompanhada pelos concorrentes, não trazendo ganho de mercado e implicando apenas na perda de lucros. Cada participante tende a seguir os progressivos aumentos de preço sob o comando do price leadership, acrescentando-se que quanto menor o número de participantes, menor a dificuldade para que todos tenham conhecimento da política comercial a ser adotada, diminuindo-se os riscos de que um dos agentes econômicos tente maximizar seus ganhos rompendo a coalizão. ${ }^{252}$

Assim, os agentes econômicos devem contar com poder de mercado suficiente, de maneira que a estrutura criada possa resultar em sua dominação. O conluio somente existe sob a incidência de uma das causas do artigo 20 da Lei $n^{\circ} 8.884 / 94$.

Os membros do cartel devem estar protegidos por barreiras à entrada de novos concorrentes, pois sem elas outros agentes econômicos que oferecem uma concorrência potencial serão estimulados a entrar no mercado e, uma vez obtido êxito, forçarão um retorno dos preços aos parâmetros iniciais.

Em vista dessas ponderações, far-se-á um breve estudo sobre a repressão penal dessas condutas anticoncorrenciais.

\subsection{Tutela Penal da Concorrência}

Não obstante a discussão, já vista em capítulo anterior, acerca da pertinência e necessidade da tutela penal da concorrência, deve-se abordar a evolução legislativa nacional sobre o tema.

${ }^{252}$ Idem. Regulação e concorrência (estudos e pareceres). P. 157. 


\subsubsection{Histórico brasileiro de repressão penal às práticas anticoncorrenciais}

As primeiras preocupações relativas à liberdade econômica surgiram com a Constituição de 1934, tratando de forma pioneira no Brasil a intervenção do Estado na economia. Em seu artigo 141, estabeleceu a possibilidade de criminalização de condutas atentatórias à economia popular. ${ }^{253}$

Com a previsão constitucional, durante o governo de Getúlio Vargas, foi promulgado, em 18 de maio de 1938, o Decreto-lei n ${ }^{\circ}$ 431/38, que definia “[...] crimes contra a personalidade internacional, a estrutura e a segurança do Estado e contra a ordem social."

De uma breve análise do diploma mencionado, salta aos olhos a ausência de objeto definido para tutela da lei. Há uma série de tipos penais esparsos tutelando bens jurídicos completamente diversos. Dentre os crimes definidos, encontram-se: incitar militares a desobedecer a lei ou a infringir de qualquer forma a disciplina; rebelar-se ou desertar; atentar contra a vida, a incolumidade ou a liberdade dos ministros do Estado; provocar ou incitar, por meio de palavras, gravuras ou inscrições de qualquer espécie, prevenção, hostilidade ou desprezo contra as forças armadas.

A evidenciar ainda mais esse caráter eclético do decreto-lei, o seu artigo $3^{\circ}$, alínea 23 prevê como crime a conduta de "[...] tentar, por meio de artifícios, promover a alta ou baixa dos preços de gêneros de primeira necessidade, com o fito de lucro ou proveito."

Como bem ressaltou Jỗo Augusto Prado DA Silveira GameIRo, ao analisar esse dispositivo legal,

\footnotetext{
“Apesar de não fazer menção expressa aos acordos entre concorrentes, a prática do cartel poderia ser incluída dentro do amplo conceito de 'artifícios', ressaltando-se, contudo, que o tipo penal se referia somente àqueles produtos de primeira necessidade, afastando-se da incidência da norma penal, por força
}

253 “[...] Artigo 141. A lei fomentará a economia popular, assegurando-lhe garantias especiais. Os crimes contra a economia popular são equiparados aos crimes contra o Estado, devendo a lei cominar-lhes penas graves e prescrever-lhes processo e julgamento adequados à sua pronta e segura punição." 
do princípio da estrita legalidade, os acordos que tivessem como objeto outros produtos não essenciais ou prestação de serviços." 254

Naquele mesmo ano, em 18 de novembro, foi inserido no ordenamento jurídico brasileiro o Decreto-lei $\mathrm{n}^{\mathrm{o}}$ 869, primeiro instrumento normativo no Brasil a prever o controle penal de condutas anticoncorrenciais, com a enumeração de crimes contra a economia popular.

Acerca de suas origens, assim leciona ROBERTO LYRA,

"Na parte relativa ao abuso do poder econômico, o Decreto-lei no 869 , de 18 de novembro de 1938, teve como fontes, além da legislação federal norte americana, o projeto argentino do Código Penal Coll-Goméz (1937) e o projeto alemão de novo Código Penal da mesma época. O projeto argentino atribuía caráter delituoso à 'formação de convênio, pacto, combinação, amálgama ou fusão de capitais tendentes a estabelecer o monopólio e lucrar com ele, num ou mais ramos de produção, do tráfego terrestre, fluvial ou marítimo ou do comércio interior ou exterior, numa localidade ou em várias, ou em todo o território nacional sem que seja necessária a realização dessa finalidade. A comissão de reforma do Código Penal alemão propusera, então, definições de primeira necessidade, à provocação de carestia, ao açambarcamento de qualquer espécie de matérias-primas, produtos industriais ou agrícolas e meios de produção, com o fim de dominar o mercado, à ofensa a qualquer preceito de economia planificada, à provocação dolosa de alta dos preços, aos abusos de 'ligas' de preços, ao processo de 'cadeias' (o Kettenhandehn), à difusão de afirmações falsas ou deturpadas em matéria de fatos capazes de influir sobre os preços do mercado ou da bolsa de mercadorias ou títulos, às indicações, conscientemente inexatas, em prospectos ou em comunicações, anúncios ou avisos, para subscrição, compra ou venda de títulos ou quotas de sociedade, à publicação ou omissão de notícias que influam sobre os preços, com o fim de oferecer, prometer, assegurar ou exigir, para si ou terceiros, um pagamento em contraste com a prestação feita." ${ }^{255}$

${ }^{254}$ GAMEIRO, João Augusto Prado da Silveira. O tratamento penal do cartel de empresas no ordenamento jurídico brasileiro. P. 172.

${ }^{255}$ LYRA, Roberto. Criminalidade econômico-financeira. Pp. 38/39. 
Seu objeto de tutela apresentava-se bem delimitado e se propunha a proteger o povo em geral e não o patrimônio individual, trazendo um caráter de proteção de bens coletivos mais definidos. ${ }^{256}$ Ainda assim, esse diploma mostrou-se longe dos interesses atuais, deixando de reconhecer a necessidade de preservação da concorrência como bem jurídico institucional, apenas exaltou a necessidade de proteção dos interesses dos consumidores e da população. Trazia expressões próprias do Direito Concorrencial, mas enaltecia a defesa do consumidor individual, equiparando os crimes contra a economia popular àqueles contra o Estado.

Dentre as condutas tipificadas, as previstas nos artigos $2^{\circ}$, inciso III, e $3^{\circ}$, inciso I, são as mais próximas da prática de formação de cartel. ${ }^{257}$

Urge destacar que referido diploma apresentava um excessivo rigor, bem ressaltado por EDUARDO REALE FERRARI:

\begin{abstract}
"Posteriormente, em 1939, enunciou-se o Decreto-Lei no 869 de 18 de novembro de 1939, definindo e enumerando sistematicamente, os crimes contra a economia popular, conceituados como danos efetivos ou potenciais ao patrimônio de um indefinido número de pessoas, estabelecendo-se o Decreto-Lei supracitado a impossibilidade da fiança, da suspensão condicional da pena e do livramento condicional ao agente, tentando-se, mais uma vez, por meio da via penal, conferir uma resposta àqueles que afrontassem a economia da nação, motivando ao Ministro Francisco Campos a comentar que no campo econômico duas alternativas apenas existiam: 'absolvição ou cadeia",258
\end{abstract}

\footnotetext{
${ }^{256}$ Assim foi definido o decreto-lei por NELSON HUNGRIA, autor do projeto respectivo: "Pode-se dizer, de modo geral, que o decreto-lei $n .869$ considera crime contra a economia popular todo fato que represente um dano efetivo ou potencial ao patrimônio de um indefinido número de pessoas. As entidades criminais que ele define podem ser assim classificadas: a) monopólios; b) artifícios, fraudes e abusos contra a economia popular; c) usura (pecuniária e real). (HUNGRIA, Nelson. Dos crimes contra a economia popular. p. 16).

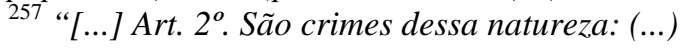

III - promover ou participar de consórcio, convênio, ajuste, aliança ou fusão de capitais, com o fim de impedir ou dificultar, para o efeito de aumento arbitrário de lucros, a concorrência em matéria de produção, transporte ou comércio; (...)

Pena: prisão celular de 2 a 10 anos e multa de 10:000\$000 a 50:000\$000. (...)

Art $3^{\circ}$. São ainda crimes contra a economia popular, sua guarda e seu emprego:

I - celebrar ajuste para impor determinado preço de revenda ou exigir do comprador que não compre de outro vendedor; (...)

Pena: prisão celular de 6 meses a 2 anos e multa de 2:00\$000 a 10:000\$000.”

258 FERRARI, Eduardo Reale. Legislação penal antitruste: direito penal econômico e sua acepção constitucional. P. 583.
} 
É importante destacar que o Decreto-lei no 869/38 trouxe substanciais melhorias na legislação "concorrencial" que se apresentava à época, mas repercutiu somente no campo da regulação de preços e na supressão de artifícios e fraudes na venda de mercadorias e não especificamente na esfera dos abusos de natureza antitruste. ${ }^{259}$

Até 1945, o Direito Antitruste brasileiro permaneceu sem modificações, quando o então ministro da Justiça da União, Agamêmnon Magalhães, incentivou a promulgação do Decreto-lei $n^{0}$ 7.666, de 22 de junho de 1945. Esse novo diploma definiu os abusos do poder econômico mais importantes e estabeleceu um órgão especializado também chamado CADE.

Ainda que não apresentasse tipos penais, estabelecia "[...] a repressão administrativa aos trustes, aos cartéis e todas aquelas combinações que visavam dominar o mercado nacional [...]", ${ }^{260}$ de maneira que preparou o terreno legislativo para a lei vindoura. $^{261}$

Por sua vez, o Decreto-lei $\mathrm{n}^{\circ}$ 9.840, de 11 de setembro de 1946, consolidou as infrações contra a economia popular, adicionando outros tipos penais àqueles previstos pelo Decreto-lei no $869 / 38$, sem inovar em matéria de crimes concorrenciais.

Ao ser alterada a legislação então vigente, foi introduzida, no ordenamento jurídico brasileiro em 26 de dezembro de 1951, ${ }^{262}$ a Lei $\mathrm{n}^{\mathrm{o}} 1.521$, que dispunha sobre crimes e contravenções penais contra a economia popular, prevendo como crime os ilícitos concorrenciais, tipificando práticas de cartel em seus artigos $2^{\circ}$, inciso VIII, ${ }^{263}$ e $3^{\circ}$, inciso III. $^{264}$

\footnotetext{
${ }^{259}$ BENJAMIN M. SHIEBER aponta um único caso em que se aplicaram disposições sobre crimes de natureza antitruste desse decreto-lei. Entende como fator que contribuiu sensivelmente para esse desuso a falta de criação de um órgão especializado com competência para executar os dispositivos antitruste do Decreto-lei no 869/38. (Op. cit., p. 06).

${ }^{260}$ Comentários de AGAMÊMNON MAGAlHãES ao Projeto 122-1948.

${ }^{261}$ BENJAMIN M. SHIEBER salienta que, apesar de sua vigência ter sido curta - foi revogado pelo Decreto-lei $\mathrm{n}^{\mathrm{o}}$ 8.167, de 09 de novembro de 1945 - e nunca ter sido executado -, sua significação para o direito antitruste brasileiro foi grande. (Op. cit., p. 08).

${ }^{262}$ Esta lei entrou em vigor somente 60 dias após a sua publicação.

263 "[...] Art. $2^{\circ}$. São crimes desta natureza: (...)

VIII - celebrar ajuste para impor determinado preço de revenda ou exigir do comprador que não compre de outro vendedor; (...)

Pena - detenção, de 6 (seis) meses a 2 (dois) anos, e multa, de dois mil a cinqüenta mil cruzeiros."

264 “[...] Art. $3^{\circ}$. São também crimes dessa natureza: (...)
} 
Não houve grande inovação com a promulgação desta lei, pois ela continuou a tratar os crimes concorrenciais como atentatórios à economia popular, apenas visando a proteção aos consumidores. Quanto aos tipos penais, estes já estavam definidos pelo Decreto-lei $n^{\circ} 869 / 38$.

Não obstante, Benjamin M. SHIEBER destaca que no “[...] direito brasileiro, a gênese da lei antitruste encontra-se nos dispositivos que tratam dos crimes contra a economia popular.” ${ }^{265}$ PASCOAL MANTECCA, por sua vez, considera que um

\footnotetext{
"[...] dos momentos históricos mais relevantes para a economia popular foi, sem dúvida, a promulgação da Lei n. 1.521/51. Essa lei relacionou e definiu, com maior alcance jurídico e precisão punitiva, os crimes e contravenções referentes à economia do povo." 266
}

De toda a sorte, a Lei $\mathrm{n}^{\circ} 1.521 / 51$ trilhou o mesmo caminhou que o Decreto-lei $\mathrm{n}^{\circ}$ 869/38, não havendo aplicação concreta de seus dispositivos de natureza antitruste. Em seu lugar, foi promulgada a Lei $\mathrm{n}^{\circ}$ 8.137/90, que “[...] define crimes contra a ordem tributária, econômica e contra as relações de consumo."

Na realidade, a nova lei derrogou a de $\mathrm{n}^{\mathrm{o}}$ 1.521/51, “[...] na medida em que reproduz as mesmas figuras criminosas ali previstas, cria figuras novas e mantém outras ali contidas." 267

\subsubsection{Lei $n^{0}$ 8.137/90: os crimes contra a ordem econômica}

A exposição de motivos $n^{\circ}$ 088, de 28 de março de 1990, que acompanhou o projeto de lei futuramente transformado na Lei $n^{\circ} 8.137 / 90$, especificamente no que se refere à justificação dos artigos de natureza concorrencial, afirmou buscar coibir

III - promover ou participar de consórcio, convênio, ajuste, aliança ou fusão de capitais, com o fim de impedir ou dificultar, para o efeito de aumento arbitrário de lucros, a concorrência em matéria de produção, transportes ou comércio; (...)

Pena - detenção, de 2 (dois) anos a 10 (dez) anos, e multa, de vinte mil a cem mil cruzeiros."

${ }^{265}$ SHIEBER, Benjamin M. Op. cit., p. 04.

${ }^{266}$ MANTECCA, Pascoal. Crimes contra a economia popular e sua repressão. P. 03.

${ }^{267}$ STOCO, Rui. Crimes contra a ordem tributária. In: FRANCO, Alberto Silva et alli. (coord.) Leis penais e sua interpretação jurisprudencial. Pp. 71/72. No mesmo sentido, entendendo que referida lei não mais vigora como um todo, cf. OLIVEIRA, Eugênio Pacelli de. Curso de processo penal. P. 635. 
“[...] a prática de crimes de abuso do poder econômico, que tanto têm sobressaltado a sociedade brasileira, com notório agravamento nos últimos tempos..."; "cuidar de instituir legislação protetora da economia popular e da efetiva defesa do consumidor, esmagada pela crescente audácia na prática de tais fatos anti-sociais, de outro turno cerceadora da livre concorrência [...]"

A Lei $n^{\circ} 8.137 / 90$, além de prever os crimes contra a ordem tributária em seus artigos $1^{\circ}$ a $3^{\circ}$, define os crimes contra a ordem econômica em seus artigos $4^{\circ}, 5^{\circ}$ e $6^{\circ}$, sendo os dois primeiros específicos delitos concorrenciais. ${ }^{268}$

268 “[...] Art. $4^{\circ}$ Constitui crime contra a ordem econômica:

I- abusar do poder econômico, dominando o mercado ou eliminando, total ou parcialmente, a concorrência mediante:

a) ajuste ou acordo de empresas;

b) aquisição de acervos de empresas ou cotas, ações, títulos ou direitos;

c) coalizão, incorporação, fusão ou integração de empresas;

d) concentração de ações, títulos, cotas, ou direitos em poder de empresa, empresas coligadas ou controladas, ou pessoas físicas;

e) cessação parcial ou total das atividades da empresa;

f) impedimento à constituição, funcionamento ou desenvolvimento de empresa concorrente.

II - formar acordo, convênio, ajuste ou aliança entre ofertantes, visando:

a) à fixação artificial de preços ou quantidades vendidas ou produzidas;

b) ao controle regionalizado do mercado por empresa ou grupo de empresas;

c) ao controle, em detrimento da concorrência, de rede de distribuição ou de fornecedores.

III - discriminar preços de bens ou de prestação de serviços por ajustes ou acordo de grupo econômico, com o fim de estabelecer monopólio, ou de eliminar, total ou parcialmente, a concorrência;

IV - açambarcar, sonegar, destruir ou inutilizar bens de produção ou de consumo, com o fim de estabelecer monopólio ou de eliminar, total ou parcialmente, a concorrência;

$V$ - provocar oscilação de preços em detrimento de empresa concorrente ou vendedor de matéria-prima, mediante ajuste ou acordo, ou por outro meio fraudulento;

VI - vender mercadorias abaixo do preço de custo, com o fim de impedir a concorrência;

VII - elevar sem justa causa o preço de bem ou serviço, valendo-se de posição dominante no mercado.

Pena - reclusão, de 2 (dois) a 5 (cinco) anos, ou multa.

Art. $5^{\circ}$ Constitui crime da mesma natureza:

I - exigir exclusividade de propaganda, transmissão ou difusão de publicidade, em detrimento de concorrência;

II - subordinar a venda de bem ou a utilização de serviço à aquisição de outro bem, ou ao uso de determinado serviço;

III - sujeitar a venda de bem ou a utilização de serviço à aquisição de quantidade arbitrariamente determinada;

IV - recusar-se, sem justa causa, o diretor, administrador, ou gerente de empresa a prestar à autoridade competente ou prestá-la de modo inexato, informando sobre o custo de produção ou preço de venda.

Pena - detenção, de 2 (dois) a 5 (cinco) anos, ou multa.

Parágrafo único. A falta de atendimento da exigência da autoridade, no prazo de 10 (dez) dias, que poderá ser convertido em horas em razão da maior ou menor complexidade da matéria ou da dificuldade quanto ao atendimento da exigência, caracteriza a infração prevista no inciso IV.

Art. $6^{\circ}$ Constitui crime da mesma natureza:

I - vender ou oferecer à venda mercadoria, ou contratar ou oferecer serviço, por preço superior ao oficialmente tabelado, ao regime legal de controle;

II - aplicar fórmula de reajustamento de preços ou indexação de contrato proibida, ou diversa daquela que for legalmente estabelecida, ou fixada por autoridade competente; 
Após a entrada em vigor da Lei $n^{\circ}$ 8.884/94, que dispõe sobre a prevenção e repressão às infrações contra a ordem econômica, continuou a viger a Lei $n^{\circ}$ 8.137/90, porque, ainda que ambas tratem da mesma matéria, aquela se limitou à esfera administrativa, enquanto esta última à esfera penal.

Vale destacar posicionamento contrário sustentado por José INÁcio GonZAGA FRANCESCHINI, segundo o qual a Lei ${ }^{\circ} 8.884 / 94$ possui natureza penal econômica e por este motivo a sua promulgação significou a derrogação dos $\operatorname{artigos} 4^{\circ}$ e $5^{\circ}$ da Lei $n^{o}$ $8.137 / 90,{ }^{269}$ com exceção do inciso VII do artigo $4^{\circ}$, por força do quanto determinado expressamente no artigo 85 daquela lei. ${ }^{270}$

Para o autor, o Direito Penal comum tutela interesses fundamentais pelas sanções penais, sendo o Direito Penal econômico um ramo deste direito, não podendo se olvidar que o ordenamento neocapitalista brasileiro consagra a livre concorrência enquanto interesse fundamental, constituindo sua violação uma causa à aplicação da sanção penal. Para FRANCESCHINI, o direito da concorrência é o "[...] ramo do direito penal-econômico que disciplina as relações de mercado entre os agentes econômicos e os consumidores, tutelando-lhes sob sanção, o pleno exercício do direito à livre Concorrência como instrumento da livre iniciativa, em prol da coletividade." 271

Ao seguir este raciocínio, considera-se que o CADE possui função quasejurisdicional e exerce atividade para-jurisdicional penal, revestindo-se, por força constitucional (artigo $173, \S 4^{\circ}$ ), do direito de persecução penal econômica. ${ }^{272}$ Esse não é o entendimento preponderante na doutrina, o que não afasta, contudo, a estreita semelhança entre os dispositivos de ambas as leis.

III - exigir, cobrar ou receber qualquer vantagem ou importância adicional de preço tabelado, congelado, administrado, fixado ou controlado pelo Poder Público, inclusive por meio da adoção ou de aumento de taxa ou outro percentual, incidente sobre qualquer contratação.

Pena - detenção, de 1 (um) a 4 (quatro) anos, ou multa."

${ }^{269}$ CARLYLE POPP e EDSON VIEIRA ABDALA entendem que a Lei ${ }^{\circ}$ 8.884/94 “[...] dispõe sobre a prevenção e repressão às infrações contra a ordem econômica, inserindo, definitivamente, o texto legal mencionado um novo ramo do direito pátrio, chamado administrativo-econômico-penal [...]” e, por esse motivo, diversos dispositivos da Lei no 8.137/90 estariam revogados. (Comentários à nova lei antitruste - Lei $\mathbf{n}^{\mathbf{0}}$ 8.884/94. P. 19).

270 “[... A Art. 85. O inciso VII do art. $4^{\circ}$ da Lei $n^{\circ}$ 8.137, de 27 de dezembro de 1990, passa a vigorar com a seguinte redação: (...)

"Art. $4^{\circ}(\ldots)$

VII - elevar sem justa causa o preço de bem ou serviço, valendo-se de posição dominante no mercado."

${ }^{271}$ FRANCESCHINI, José Inácio Gonzaga. Roteiro do processo penal-econômico na legislação de concorrência. P. 10.

${ }^{272}$ Idem, ibidem. 
Ao comentar a Lei $\mathrm{n}^{\circ} 8.137 / 90$, Miguel REALE JúNIOR sustenta que os artigos $4^{\circ} \mathrm{e}$ $5^{\circ}$ reproduzem, em grande parte, a Lei ${ }^{\circ} 4.137 / 62$, bem como dispositivos do Anteprojeto da Parte Especial do Código Penal de 1984. Da mesma forma, os dispositivos da Lei ${ }^{\circ}$ $8.884 / 94$ apresentam figuras semelhantes àquelas previstas como crime. ${ }^{273}$

É relevante notar

\begin{abstract}
“[...] que as condutas têm descrições típicas semelhantes e visam à proteção do mesmo bem jurídico - a livre concorrência - contra impedimentos ou prejuízos ao seu correto desenrolar, reprimindo-se, igualmente, na defesa da livre concorrência, o domínio de mercado relevante e o abuso de posição dominante." 274
\end{abstract}

Aponta o autor, porém, que há diferença marcante especificamente no elemento subjetivo, pois na legislação concorrencial as infrações administrativas prescindem de culpa para a sua configuração, enquanto nos tipos penais previstos na Lei $n^{\circ} 8.137 / 90$, a ação do agente é obrigatoriamente dolosa.

Nesse ponto, cumpre enunciar que os tipos penais em tela, exceto o disposto no inciso IV e no parágrafo único do artigo $5^{\circ}$ desse diploma legal, exigem o elemento subjetivo geral e um especial fim de agir por parte do autor. Esta é representada pela intenção de dominar o mercado ou eliminar, total ou parcialmente, a concorrência. ${ }^{275}$

Na lei antitruste, conforme observa MiguEL REALE JÚNIOR, há um respeito menor à descrição típica e à admissão de outras condutas não expressamente elencadas - o que contraria os princípios penais -, bem como com relação ao elemento subjetivo das práticas anticoncorrenciais. $^{276}$

A esse propósito, importante destacar que embora a Lei $n^{\circ} 8.137 / 90$ respeite um pouco mais os princípios garantísticos da lei penal, peca, por outro lado, pela falta de técnicas legislativa e jurídica e de maior clareza quanto aos elementos normativos

\footnotetext{
${ }^{273}$ REALE JÚNIOR, Miguel. Despenalização no direito penal econômico: uma terceira via entre o crime e a infração administrativa? Pp. 117 a 124.

${ }^{274}$ Idem, ibidem, p. 121.

${ }^{275}$ OLIVEIRA JÚNIOR, Gonçalo Farias de. Op. cit., p. 167.

${ }^{276}$ REALE JÚNIOR, Miguel. Despenalização no direito penal econômico: uma terceira via entre o crime e a infração administrativa? P. 121.
} 
dispostos. Os tipos penais apresentam vocábulos que dificultam a nitidez e a unicidade das condutas proibidas, de modo que ampliam os limites exegéticos da lei conferidos ao arbítrio do julgador.

É dentre esses tipos penais que se encontra o delito de formação de cartel, especificamente no artigo $4^{\circ}$ e seus incisos I, alíneas "a" e "b", III e V.

Com a recente publicação da Lei $\mathrm{n}^{\circ}$ 12.529/11, que reestruturou o Sistema Brasileiro de Defesa da Concorrência, a Lei $n^{\circ} 8.137 / 90$ sofreu grandes alterações, ${ }^{277}$ de maneira que foram revogados os seus artigos $5^{\circ}$ e $6^{\circ}$ e nova redação foi dada ao artigo $4^{\circ}$, que assim passará a vigorar:

"I - abusar do poder econômico, dominando o mercado ou eliminando, total ou parcialmente, a concorrência mediante qualquer forma de ajuste ou acordo de empresas;

a) (revogada);

b) (revogada);

c) (revogada);

d) (revogada);

e) (revogada);

f) (revogada);

II - formar acordo, convênio, ajuste ou aliança entre ofertantes, visando:

a) à fixação artificial de preços ou quantidades vendidas ou produzidas;

b) ao controle regionalizado do mercado por empresa ou grupo de empresas;

c) ao controle, em detrimento da concorrência, de rede de distribuição ou de fornecedores.

Pena - reclusão, de 2 (dois) a 5 (cinco) anos e multa.

III - (revogado);

IV - (revogado);

V - (revogado);

VI - (revogado);

${ }^{277}$ Embora a Lei $n^{\circ} 8.137 / 90$ tenha sido alterada, continua a repetir condutas já previstas como infrações administrativas e mantém tipos penais formados por inúmeros elementos normativos. 


$$
\text { VII - (revogado). ” }
$$

É este delito remanescente - a formação de cartel - que o Programa de Leniência, tema central do presente trabalho, pretende combater, constando, até, da Cartilha sobre combate a cartéis e programa de leniência elaborada pela Secretaria de Direito Econômico, que

\footnotetext{
“[...] via de regra, cartéis são difíceis de detectar e investigar sem a cooperação dos participantes da conduta, dado seu caráter sigiloso e fraudulento. Por essa razão, um número expressivo de jurisdições adotaram programas de leniência de modo a desvendar tais condutas, tais como África do Sul, Alemanha, Austrália, Canadá, Espanha, Estados Unidos, França, Holanda, Hungria, Irlanda, Israel, Japão, Nova Zelândia, Portugal, Reino Unido e União Européia.” 278
}

Insta destacar, entretanto, que os benefícios criminais advindos da celebração e cumprimento do acordo de leniência podem atingir a punibilidade de todos os delitos previstos na Lei nº $8.137 / 90$, como será visto no Capítulo 4.

\subsubsection{Prova dos crimes contra a ordem econômica}

Qualquer que seja a forma adotada para a celebração das condutas anticoncorrenciais, em especial o delito de cartel, a colheita de provas acerca da ilicitude dessas práticas mostra-se extremamente complexa, porquanto é quase improvável a documentação de seu objeto, com menções expressas às partes autoras e ao seu intuito de eliminação da concorrência. ${ }^{279}$ A natureza sigilosa das ações desenvolvidas pelos mentores e participantes desses ilícitos torna extremamente difícil a obtenção da prova de sua ocorrência.

\footnotetext{
${ }^{278}$ BRASIL. MINISTÉRIO DA JUSTIÇA. SECRETARIA DE DIREITO ECONÔMICO. Cartilha sobre combate a cartéis e programa de leniência. $P$. 14.

${ }^{279}$ Nesse sentido, GRINBERG, Mauro. Processos atacam prática de cartel.
} 
Geralmente, o acordo não é formalizado, bastando uma combinação verbal acerca das condutas estabelecidas pelas partes e de seu intuito anticoncorrencial. Por vezes, são utilizados até recursos tecnológicos que dificultam, sobremaneira, a identificação do ajuste e permitem às partes a combinação do ilícito à distância sem deixar rastros, tais como o skype, telefones criptografados e rádios.

\section{De acordo com BENJAMIN M. SHIEBER:}

"A dificuldade em encontrar provas documentais, decorre do fato de raramente acontecer que conspiradores que visam praticar um abuso de poder econômico lavrem e arquivem atas de suas reuniões, tanto quanto provas testemunhais, pois é evidente que não podemos esperar que os participantes de acordo em restrição da concorrência testemunhassem contra si e admitissem a existência de tal acordo. Freqüentemente, negam eles a existência de qualquer concordância de vontades, e portanto, a existência de um acordo." 280

Vale rememorar que

“[...] independentemente do grau de dificuldade na obtenção de provas - em atenção às garantias fundamentais previstas pela Constituição Federal e em nome da segurança jurídica - uma condenação pelo Conselho Administrativo de Defesa Econômica (Cade) só é admissível caso a conduta ilícita esteja provada nos autos do processo administrativo.

Isto significa que a mera observância de indícios de conduta concertada, como, por exemplo, a estabilidade na curva de preços de um mercado relevante, não é suficiente para determinar a existência de um acordo para eliminação da concorrência. A uniformização dos preços pode ser decorrência do estado normal daquele mercado e tantos outros indícios podem ter explicações lógicas e plausíveis. Assim, verificadas evidências que levem a crer que em um mercado relevante possa existir um cartel, a produção de prova da ocorrência deste ilícito é indispensável para que se possa condenar um agente econômico."281

${ }^{280}$ SHIEBER, Benjamin M. Op. cit., p. 87.

${ }^{281}$ FÉLIX, Natália. Direito concorrencial. Considerações sobre a repressão aos cartéis no Brasil. 
Basicamente, são dois os meios de prova utilizados pelas autoridades antitruste: as provas circunstanciais e as análises econômicas.

Na opinião de JoÃo Augusto Prado DA SILVEIRA GAMEIRO:

\begin{abstract}
“As análises econômicas são essenciais em situações nas quais determinado fato só encontra explicação na existência de um acordo entre os concorrentes, como por exemplo, na realização de uma reunião em uma entidade de classe em determinado dia e a verificação de um aumento de preços idêntico no dia imediatamente seguinte. Apesar de existirem várias características identificáveis em certos mercados que facilitam e estimulam a formação de um cartel e, em diversos casos, se constatar uma similitude de preços entre concorrentes, tais elementos não são suficientes para a comprovação da prática anticoncorrencial. Nesse contexto, as análises econômicas servirão como instrumento para verificação se certas variáveis econômicas são decorrência de racionalidade do comportamento dos agentes de mercado, ou, ao contrário, se só podem ser explicadas justamente pela existência de um acordo artificial entre concorrentes.",282
\end{abstract}

Ainda que se considere importante esse meio de investigação e aferição da ilicitude da conduta anticoncorrencial, é inegável a dificuldade que persiste na comprovação dessa prática. Os entendimentos verbais e a preocupação dos agentes em não documentarem nada a respeito da colusão ainda persistem.

Por essa razão, nos últimos anos, tem-se visto uma intensificação nas investigações e combate às condutas anticoncorrenciais, sobretudo, à formação de cartéis. É notável a progressiva adoção de meios mais rigorosos de apuração e ferramentas mais sofisticadas de investigação no âmbito administrativo, como a realização de buscas e apreensões, ${ }^{283}$

\footnotetext{
${ }^{282}$ GAMEIRO, João Augusto Prado da Silveira. Op. cit., p. 115.

283 “[...] Art. 35-A. A Advocacia-Geral da União, por solicitação da SDE, poderá requerer ao Poder Judiciário mandado de busca e apreensão de objetos, papéis de qualquer natureza, assim como de livros comerciais, computadores e arquivos magnéticos de empresa ou pessoa física, no interesse da instrução do procedimento, das averiguações preliminares ou do processo administrativo, aplicando-se, no que couber, o disposto no art. 839 e seguintes do Código de Processo Civil, sendo inexigível a propositura de ação principal.

$\S 1^{\circ}$ No curso de procedimento administrativo destinado a instruir representação a ser encaminhada à SDE, poderá a SEAE exercer, no que couber, as competências previstas no caput deste artigo e no art. 35 desta Lei.

$\S 2^{\circ}$ O procedimento administrativo de que trata o parágrafo anterior poderá correr sob sigilo, no interesse das investigações, a critério da SEAE."
} 
inspeções, ${ }^{284}$ interceptações telefônicas, telemáticas e escutas ambientais. O CADE, inclusive, passou a impor multas recordes a empresas e administradores considerados culpados pela prática de cartéis.

Ainda na esfera criminal, houve um recrudescimento nas investigações, levando à concretização de cooperações entre a Secretaria de Direito Econômico, o Ministério Público $^{285}$ e as Polícias Federal ${ }^{286}$ e Civil. Entre os novos instrumentos de investigação, merece maior destaque o acordo de leniência, objeto do próximo capítulo.

284 “[...] Art. 35 (...) $\$ 2^{\circ}$ Respeitado o objeto de averiguação preliminar, de procedimento ou de processo administrativo, compete ao Secretário da SDE autorizar, mediante despacho fundamentado, a realização de inspeção na sede social, estabelecimento, escritório, filial ou sucursal de empresa investigada, notificandose a inspecionada com pelo menos vinte e quatro horas de antecedência, não podendo a diligência ter início antes das seis ou após às dezoito horas.

$\S 3^{o} \mathrm{Na}$ hipótese do parágrafo anterior, poderão ser inspecionados estoques, objetos, papéis de qualquer natureza, assim como livros comerciais, computadores e arquivos magnéticos, podendo-se extrair ou requisitar cópias de quaisquer documentos ou dados eletrônicos."

${ }^{285}$ Em 2008, foi criado em São Paulo o Grupo de atuação especial de repressão à formação de cartel e à lavagem de dinheiro e de recuperação de ativos (GEDEC). Este grupo tem como funções a recuperação de ativos obtidos mediante condutas ilícitas, a repressão aos delitos contra a ordem econômica, em especial o crime de formação de cartel, excetuados aqueles contra as relações de consumo, e a repressão ao delito de lavagem de dinheiro. Em seguida, o Ministério Público da Paraíba criou órgão específico em sua estrutura para o combate a cartéis.

Em 2010, o Ministério Público do Estado do Rio de Janeiro criou a Divisão Anticartel e de Defesa da Ordem Econômica do Ministério Público do Estado do Rio de Janeiro (DACAR), a qual foi criada para intensificar a atuação do Ministério Público no combate ao crime organizado, que opera por meio de cartéis. Dentro da estrutura da DACAR funciona o Laboratório Anticartel, resultado de convênio celebrado em dezembro de 2009 entre o MP-RJ e a Secretaria de Direito Econômico do Ministério da Justiça (SDE).

${ }^{286}$ Em 2007, a Secretaria de Direito Econômico e a Polícia Federal assinaram um convênio de cooperação mútua para o combate a cartéis. O acordo previa a criação do Centro de Investigações de Cartel, com a finalidade de coordenar a troca de informações entre os dois órgãos. 


\section{CAPÍTULO 4 O ACORDO DE LENIÊNCIA}

\subsection{Acordo de Leniência: Noções e Conceito}

O fenômeno da globalização foi responsável pela crescente internacionalização das economias nacionais e pela transnacionalização das empresas, acarretando significativos incrementos e transformações nas práticas comerciais. Não obstante os benefícios trazidos pela liberalização comercial, como os avanços tecnológicos e a expansão das economias, a disputa pelo mercado tornou-se cada vez mais intensa, o que levou a uma frequência maior das operações de concentração de empresas e da formação de cartéis. ${ }^{287}$

Nesse particular, acompanhando uma preocupação global, a investigação de condutas real ou potencialmente anticompetitivas passou a constituir uma das prioridades do Sistema Brasileiro de Defesa da Concorrência. Dentre estas condutas, o cartel é visto como a mais grave lesão à concorrência, ocupando, assim, o alvo central das autoridades antitruste brasileiras. ${ }^{288}$

Em virtude desse acirrado combate a cartéis, hodiernamente os autores dessa empreitada criminosa utilizam-se de meios modernos e sofisticados, tais como correspondências eletrônicas, conversas telefônicas e telemáticas em tempo real, dificultando cada vez mais a atuação investigativa.

Afora isso, a ilegalidade e clandestinidade que revestem a formação e atuação dos cartéis tornam a sua investigação e comprovação ainda mais complexas, exigindo dos órgãos estatais instrumentos de investigação a cada dia mais eficientes. Assim, cada vez mais recursos foram sendo direcionados, com o objetivo de pôr fim a essa prática, considerada uma das mais lesivas aos consumidores e à ordem econômica.

Mesmo com o aumento de sanções e adoção de práticas de inspeção e busca e apreensão (dawn raids), ${ }^{289}$ os cartéis continuavam difíceis de detectar e investigar sem a cooperação dos próprios participantes da conduta, dado seu caráter sigiloso e fraudulento,

\footnotetext{
${ }^{287}$ VILELA, Juliana Girardelli. Aspectos relevantes do programa de leniência. P. 202.

${ }^{288}$ BRASIL. MINISTÉRIO DA JUSTIÇA. SECRETARIA DE DIREITO ECONÔMICO. Cartilha sobre combate a cartéis e programa de leniência. $P$. 06.

289 RODAS, João Grandino. Dawn raids busca e apreensão no âmbito antitruste - práticas e recomendações. Pp. 417/431.
} 
exigindo-se dos órgãos de defesa da concorrência mecanismos capazes de desestruturar internamente o cartel de modo que a prática viesse a público.

Assim surgiu - não só no Brasil, mas em um número expressivo de jurisdições, como: África do Sul, Alemanha, Austrália, Áustria, Canadá, Espanha, Estados Unidos, França, Grécia, Holanda, Hungria, Irlanda, Israel, Japão, Nova Zelândia, Portugal, Reino Unido e União Europeia - o chamado Programa de Leniência. ${ }^{290}$

Ao instituir esse programa,

“[...] a Lei $\mathrm{n}^{\mathrm{o}}$ 8.884/94 reconhece que é do interesse dos consumidores brasileiros conceder benefícios àquele participante de cartel que queira por um fim na conduta e cooperar de forma plena e ampla com as autoridades de defesa da concorrência de modo a permitir a condenação dos demais participantes do cartel. $\mathrm{O}$ interesse dos cidadãos brasileiros de ver desvendados e punidos cartéis supera o interesse de sancionar uma única empresa ou indivíduo que possibilitou a identificação, desmantelamento e punição de todo o cartel." 291

O Programa de Leniência foi introduzido à Lei $n^{\circ}$ 8.884/94 pela Medida Provisória $\mathrm{n}^{\circ}$ 2.055, de 11 de agosto de 2000. Após três edições, a Medida Provisória foi convertida na Lei ${ }^{\circ}$ 10.149/2000 e consolidou, dentre outros, os artigos 35-B e 35-C na Lei de Defesa da Concorrência.

Atualmente, com a recente aprovação da Lei $\mathrm{n}^{\circ}$ 12.529/11, ainda em período de vacatio legis, foi determinada a revogação destes dispositivos e conferida nova regulamentação ao instituto prevista nos artigos 86 e 87 deste diploma legal, os quais serão analisados no subitem 4.3 .

O programa é também regulamentado pela Portaria do Ministério da Justiça no 456, de 15 de março de 2010, que trata de diversas espécies de processos administrativos com

\footnotetext{
${ }^{290}$ SHERIDAN SCOTT, em palestra proferida para a Federação das Indústrias do Estado de São Paulo (FIESP) em 12 de maio de 2008, reafirma a importância do Programa de Leniência em todo o mundo, asseverando que "[...] por ser o cartel uma prática escondida, o desafio na aplicação da Lei é a detecção e a nossa ferramenta número um para vencer esse desafio é o programa de imunidade, o chamado cartão 'livre da cadeia.",

${ }^{291}$ BRASIL. MINISTÉRIO DA JUSTIÇA. SECRETARIA DE DIREITO ECONÔMICO. Cartilha sobre combate a cartéis e programa de leniência. P. 17.
} 
especialização na apuração, prevenção ou repressão de infrações contra a ordem econômica no âmbito da Secretaria de Direito Econômico. Nos termos dessa Portaria, o Programa de Leniência é o "[...] instrumento fundamental para garantir a plena concretização do princípio constitucional da livre concorrência, com especial relevância para a implementação da Política Brasileira de Combate a Cartéis.” Portanto, consiste em um conjunto de iniciativas que visa

"I - detectar, investigar e punir infrações contra a ordem econômica, notadamente aquelas previstas nos artigos 20 e 21, I, II, III, IV e VIII, ambos da Lei $n^{\circ} 8.884$, de 11 de junho de 1994;

II - informar e orientar permanentemente as empresas e os cidadãos em geral, a respeito dos direitos e garantias previstos nos artigos 35-B e 35-C da Lei $\mathrm{n}^{\circ}$ 8.884, de 11 de junho de 1994;

III - conscientizar os órgãos públicos a respeito da importância do Acordo de Leniência como instrumento fundamental de repressão e punição das infrações contra a ordem econômica; e

IV - assistir, apoiar, orientar e incentivar os proponentes à celebração de Acordo de Leniência. ${ }^{292}$

O termo leniência, proveniente do latim lenitate, corresponde à lenidade, isto é, "brandura, suavidade, doçura, mansidão" ${ }^{293}$ De acordo com IBRAHIM ACÁCIO ESPÍRITO SOBRAL, transpondo a definição para a seara do Direito Concorrencial, leniência pode ser vista como “[...] qualquer sanção ou obrigação que seja considerada menos severa que aquela exigida na falta de uma cooperação plena e voluntária." 294

Ou seja,

“[...] quando os cartéis estiverem sujeitos a sanções criminais, a leniência normalmente adquirirá a forma de concessão de imunidade do processo criminal, mas independente disso, a leniência geralmente adquirirá também a

\footnotetext{
${ }^{292}$ Art. 59, da Portaria do Ministério da Justiça no 456/2010.

${ }^{293}$ FERREIRA, Aurélio Buarque de Holanda. Op. cit., p. 1200.

${ }^{294}$ SOBRAL, Ibrahim Acácio Espírito. O acordo de leniência: avanço ou precipitação? P. 132.
} 
forma de redução de multas no âmbito do processo administrativo em trâmite perante o órgão de defesa da concorrência.",295

Criado para superar o desafio constante de preservar um ambiente de concorrência saudável no mercado brasileiro, o acordo de leniência passou a exigir dos agentes econômicos uma nova postura de plena cooperação com as autoridades antitruste.

Segundo ANDrÉ Maciel VARgas dos SANTOS, o acordo de leniência é um ajuste

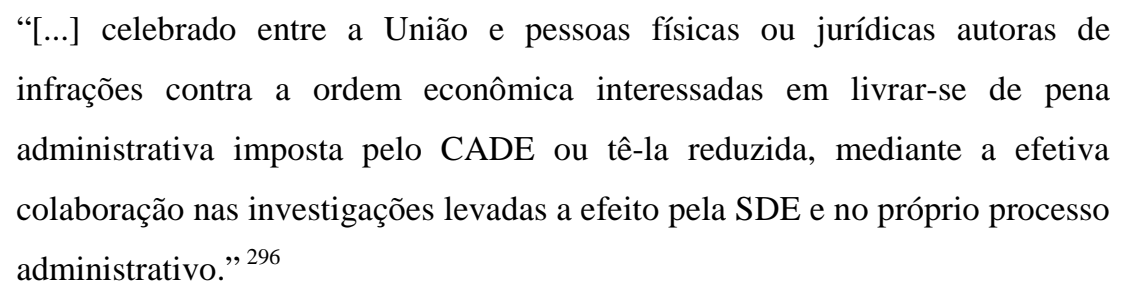

Nas palavras de CAROLINE SANSELme VIEIRA “[...] é, em síntese, uma delação premiada: o proponente denuncia a existência de um cartel do qual ele faz parte e obtém, como prêmio, conforme o caso, a extinção da ação punitiva ou a redução da pena aplicável." 297

GESNER OLIVEIRA e JOÃo GRANDINO RodAS, por sua vez, o definem como

\begin{abstract}
"[...] uma transação entre o Estado e o delator que, em troca de informações que viabilizem a instauração, a celeridade e a melhor fundamentação do processo, possibilita um abrandamento ou extinção da sanção em que este incorreria, em virtude de haver também participado na conduta ilegal." 298
\end{abstract}

Desta forma, é um instrumento de política criminal que amplia os poderes de investigação dos órgãos responsáveis pela fiscalização do Sistema Brasileiro de Defesa da Concorrência, a fim de que se permita a colaboração do agente infrator, utilizando-se do direito premial.

\footnotetext{
295 Idem, ibidem.

${ }^{296}$ SANTOS, André Maciel Vargas dos. O acordo de leniência e seus reflexos no direito penal.

${ }^{297}$ VIEIRA, Caroline Sanselme. O primeiro acordo de leniência firmado no Brasil. P. 95.

298 OLIVEIRA, Gesner; RODAS, João Grandino. Direito e economia da concorrência. Pp. 41/42.
} 
Aliás, cumpre ressaltar que um dos motivos do êxito do Programa de Leniência reside na própria dificuldade em se atingir e manter um consenso entre os membros do cartel, pois os participantes possuem diferentes custos, estimativas das demandas de mercado e objetivos.

É comum os integrantes do cartel sentirem-se tentados a "furar" o acordo, fazendo pequenas reduções de preços com vistas a adquirir fatias maiores do mercado do que aquela que the foi alocada. Por isso, os órgãos antitruste decidiram maximizar essa permanente instabilidade oferecendo benefícios àqueles que optarem por delatar a prática do cartel e cooperar com as investigações. ${ }^{299}$

\subsubsection{Requisitos para a sua celebração}

O acordo de leniência e os requisitos para o seu cumprimento estão previstos nos artigos 35-B e 35-C da Lei no 8.884/94, bem como no artigo 59 e seguintes da Portaria do Ministério da Justiça ${ }^{\circ} 456$ publicada em 15 de março de 2010. O artigo 35-B, da Lei no 8.884/94, dispõe em seu $\S 2^{\circ}$ que o acordo somente poderá ser celebrado se cumpridos, cumulativamente, os seguintes requisitos:

"I - empresa ou pessoa física seja a primeira a se qualificar com respeito à infração noticiada ou sob investigação;

II - a empresa ou pessoa física cesse completamente seu envolvimento na infração noticiada ou sob investigação a partir da data da propositura do acordo;

III - a SDE não disponha de provas suficientes para assegurar a condenação da empresa ou pessoa física quando da propositura do acordo; e

IV - a empresa ou pessoa física confesse sua participação no ilícito e coopere plena e permanentemente com as investigações e o processo administrativo, comparecendo, sob suas expensas, sempre que solicitada, a todos os atos processuais, até seu encerramento. ${ }^{300}$

\footnotetext{
${ }^{299}$ VILELA, Juliana Girardelli. Op. cit., p. 203.

${ }^{300}$ Os requisitos e condições para celebração do acordo de leniência também constam dos artigos 60, 61 e 73 da Portaria do Ministério da Justiça nº 456, de 15 de março de 2010.
} 
A preocupação primordial do legislador foi possibilitar que apenas um infrator pudesse celebrar o acordo e fosse, posteriormente, beneficiado pela imunidade. A Secretaria de Direito Econômico, portanto, somente celebrará o acordo com o primeiro que buscar o benefício e ninguém mais.

De fato, essa exigência provoca uma verdadeira corrida às autoridades antitruste para a conquista do primeiro lugar. A premiação instiga as empresas, seus funcionários e representantes a trair o cartel o mais rápido possível, a fim de receber a imunidade, reservada apenas para o mais rápido. Somente aquele que primeiro ceder à tentação de abandonar o conluio e receber a imunidade total é que ficará impune. ${ }^{301}$

Não seria tão racional se diferente fosse, pois seriam raros e demorados os casos de colaboração se todo participante do cartel recebesse imunidade total. Quem se interessaria em delatar a prática ilícita, a princípio vantajosa, se a qualquer tempo - e, quiçá, somente após a descoberta da verdade pelas autoridades - fosse permitida a celebração de acordo com o benefício da imunidade?

Afora isso, na hipótese de vários beneficiados com a leniência, conforme bem expôs ANDRÉ Maciel VARGAS dOS SANTOS,

“[...] isso daria margem a novo conluio entre parte das empresas envolvidas no cartel, as quais, sabendo que algum envolvido já tenha buscado a SDE, poderiam também intentar o acordo, diante da eminente aplicação de penalidade. E as informações poderiam, mediante acerto entre as empresas, ser repassadas em cotas, para que todas viessem a ter a punibilidade extinta ou a pena reduzida." 302

Uma outra preocupação do legislador é a cessação da atividade ilícita por parte do leniente, não sendo possível a celebração do acordo enquanto o participante continuar

\footnotetext{
301 À vista dessa previsão legal, a Secretaria de Direito Econômico criou um sistema de senhas (marker system) para proteger a posição de um candidato na fila para o acordo de leniência. A senha perdura por trinta dias, permitindo ao candidato que obtenha as informações e provas necessárias sobre a conduta ilícita. Para adquirir uma senha, ele deve fornecer algumas informações à Secretaria de Direito Econômico com: nome e endereço, participantes do cartel, bens e locais afetados e, quando possível, a duração estimada do cartel (BRASIL. MINISTÉRIO DA JUSTIÇA. SECRETARIA DE DIREITO ECONÔMICO. Cartilha sobre combate a cartéis e programa de leniência. P. 21).

${ }^{302}$ SANTOS, André Maciel Vargas dos. Op. cit, p. 13.
} 
envolvido no conluio. Este requisito torna-se óbvio quando analisado à luz da finalidade precípua do acordo de leniência, qual seja, o combate à prática cartelizadora.

Sob esta óptica, é importante lembrar que, em alguns países, como a França, o Programa de Leniência prevê a possibilidade de a autoridade antitruste solicitar ao delator que continue seu envolvimento no cartel, sem alertar os demais membros, a fim de obter, com o sigilo das investigações, provas inequívocas sobre a prática criminosa.

A própria Cartilha de combate a cartéis e programa de leniência prevê que "A SDE poderá requerer que o candidato aja de forma que não permita a identificação da ciência da SDE sobre o cartel pelos outros envolvidos, o que possibilitará à SDE maiores chances de obter provas importantes contra os outros participantes do cartel."303 Assim, embora não haja previsão expressa na legislação no sentido de que a autoridade poderá solicitar ao delator a continuidade na prática da conduta ilícita, os órgãos antitruste brasileiros não descartam essa possibilidade para obter provas mais robustas acerca do cartel.

Tal posicionamento é repudiado por alguns, porquanto seria difícil imaginar o ente público consentindo com a prática da conduta enquanto vigente o acordo. Interpreta-se tal atitude como um ato de imoralidade praticada pelo próprio Estado, pois a concordância com a manutenção da conduta equivaleria a um flagrante preparado. ${ }^{304}$

Um outro requisito exige que o candidato a leniente forneça informações inéditas à Secretaria de Direito Econômico. Essa exigência visa revelar condutas que dificilmente seriam descobertas, pois, como já explanado, não basta o paralelismo de preços ou a identidade de condutas dos concorrentes para a comprovação da prática de cartel. É preciso que se demonstre a vontade e a comunhão de esforços para o ato ilícito.

Contudo, não se pretende dos candidatos a deflagração de condutas de todo desconhecidas pela Secretaria de Direito Econômico. Este órgão pode já ter ciência da existência do conluio, mas não dispor de “[...] provas suficientes para assegurar

\footnotetext{
${ }^{303}$ BRASIL. MINISTÉRIO DA JUSTIÇA. SECRETARIA DE DIREITO ECONÔMICO. Cartilha sobre combate a cartéis e programa de leniência. Pp. 28/29.

${ }^{304}$ SANTOS, André Maciel Vargas dos. Op. cit., p. 13.
} 
condenação da empresa ou pessoa física." ${ }^{305}$ As informações prestadas devem levar as investigações a caminhos não anteriormente perpetrados.

Nas palavras de IBRAHIM ACÁCIO ESPÍRITO SOBRAL, a informação deve ser “[...] inédita e contundente[...]”, já que “[...] um dos objetivos primordiais de um programa dessa natureza é justamente descobrir dados acerca da existência de cartéis nunca dantes imaginados.", 306

Diante disso, o caput do artigo 35-B, da Lei $\mathrm{n}^{\circ} 8.884 / 94$, determina que o leniente deverá “[...] colaborar efetivamente com as investigações [...]”, resultando dessa cooperação: “[...] I - a identificação dos demais co-autores da infração; e II - a obtenção de informações e documentos que comprovem a infração noticiada ou sob investigação [...]”, frisando a relevância da revelação dos participantes do conluio, bem como o fornecimento de documentos que de fato atestem a prática criminosa.

A confissão, por sua vez, é exigência que implica a posterior concessão dos benefícios de redução da pena ou extinção da punibilidade. Assim, a legislação impõe que, além de confessar, o candidato deve cooperar permanentemente com as investigações e o processo administrativo até seu encerramento, inclusive comparecendo a todos os atos processuais.

Afinal, “[...] as informações deverão ter credibilidade, o que implica a necessidade de confirmação dos dados fornecidos pela continuação das investigações, $e$ para que o delator não seja alvo de futuras especulações, prejudicando o deslinde do caso $[\ldots]^{, 307}$

Logo, a confidencialidade do acordo é necessidade decorrente da confissão, uma vez que os lenientes estão delatando coinfratores, podendo correr riscos de retaliações comercial e pessoal. A previsão do sigilo e o rigor no tratamento das informações sigilosas

\footnotetext{
${ }^{305}$ Artigo 35-B, $\S 2^{\circ}$, inciso III.

${ }^{306}$ Cf. SOBRAL, Ibrahim Acácio Espírito. Op. cit., p. 134.

${ }^{307}$ Idem, ibidem, p. 134.
} 
são imprescindíveis, ${ }^{308}$ já que acarretam duas consequências imediatas: o sucesso das investigações e a preservação da imagem da empresa ou pessoa física delatora. ${ }^{309}$

Além desses requisitos legais, a Secretaria de Direito Econômico poderá estipular outros, a seu talante, a depender do caso, que possam assegurar a efetiva colaboração e o resultado útil do processo (artigo $35-\mathrm{B}, \S 3^{\circ}$, da Lei $\mathrm{n}^{\circ} 8.884 / 94$ ).

Há, ainda, uma ressalva à celebração do acordo prevista no $\S 1^{\circ}$ do artigo 35-B, segundo o qual é vedada a participação de “[...] empresas ou pessoas físicas que tenham estado à frente da conduta tida como infracionária."

De acordo com o legislador, não poderia o instituto ser utilizado pelos maiores infratores da ordem econômica, mediante mera confissão, para obterem benefícios de grande monta, como a redução de penalidades e a extinção da punibilidade. Para estes, a punição não merece abrandamento ou anistia, dada a gravidade de suas condutas.

\section{Segundo ANDrÉ MACIEL VARGas dos SANTOS,}

"O Estado estaria, assim, abrindo uma via "alternativa" para o empreendimento ilícito, estando o infrator sempre certo de que, ao sinal de perigo, se socorreria do próprio ente repressor para lhe abrandar as conseqüências de seu ato. $\mathrm{O}$ acordo de leniência volta-se, portanto, a copartícipes os quais, em verdade, agem como peças de uma engrenagem nociva à ordem econômica. Abre-se mão da repressão a essa espécie de infrator para desmantelar todo o aparato criminoso, buscando-se a origem intelectual da organização."310

Para IBRAHIM ACÁCIO ESPÍRITO SOBRAL, esse dispositivo legal pretende evitar a simulação de confissão. No seu entender,

“[...] o acordo de leniência não pode e nem deve servir para acobertar aqueles que estiveram à frente da conduta infracionária, e simulam uma confissão para

\footnotetext{
${ }^{308}$ A esse respeito, assim dispõe a Lei no 8.884/94: “[...] Art. 35-B (...) § $9^{\circ}$ : Considera-se sigilosa a proposta de acordo de que trata este artigo, salvo no interesse das investigações e do processo administrativo." Sobre o tema, vide artigos 63, $\S \S 1^{\circ}$ e $2^{\circ}$, e 74 da Portaria do Ministério da Justiça $n^{\circ} 456 / 2010$.

${ }^{309}$ SANTOS, André Maciel Vargas dos. Op. cit., p. 14.

${ }^{310}$ Idem, ibidem.
} 
se beneficiar pelos incentivos do programa de leniência, enquanto os demais partícipes sofrem as penalidades da lei." 311

Então, qual seria o significado da expressão "tenham estado à frente da conduta tida como infracionária"? Consoante o artigo 35-B, § 11 da Lei $\mathrm{n}^{\circ} 8.884 / 94,{ }^{312}$ a resposta consta da regulamentação editada pelo ministro de Estado da Justiça. A já revogada Portaria do Ministério da Justiça $\mathrm{n}^{\circ}$ 849, de 22 de setembro de 2000, tratou da questão definindo essa expressão como “[...] a pessoa física ou jurídica que tenha promovido ou organizado a cooperação da infração, dirigido a atividade ou ainda que tenha coagido alguém a cometê-la."

As expressões promover, organizar e dirigir são muito vagas, limitando a compreensão exata do que se pretende com esses verbetes. Não se sabe quais seriam os limites aos poderes decisório e organizacional e de direção dos membros do cartel para que não fossem considerados como à frente da conduta infracionária, podendo, assim, ser aceitos para a celebração do acordo de leniência.

Sem solucionar o problema, a Portaria do Ministério da Justiça $n^{\circ} 04$, de 05 de janeiro de 2006, já revogada, apresentou dispositivo nesse mesmo sentido (artigo 72.) ${ }^{313}$

Por sua vez, a Portaria do Ministério da Justiça nº 456, de 15 de março de 2010, dispôs de maneira diversa sobre o tema, prevendo, no parágrafo único do artigo 61, que "[...] não serão consideradas como tendo estado à frente da infração noticiada partes que desempenham papéis equivalentes em seu funcionamento."

Dessa maneira, a Portaria dispensou os termos promover, organizar e dirigir ou coação, determinando que todos que não desempenharam participação equivalente na prática ilícita, ou seja, todos aqueles que se destacaram de alguma forma no envolvimento do cartel são considerados como se estivessem à frente da conduta infracionária. Seja pela liderança, seja pela coação de terceiros, seja pela organização do conluio, seja, ainda, da

\footnotetext{
${ }^{311}$ SOBRAL, Ibrahim Acácio Espírito. Op. cit., p. 136.

312 "A aplicação do disposto neste artigo observará a regulamentação a ser editada pelo Ministro de Estado da Justiça."

313 “[...] Art. 72. Do instrumento do Acordo de Leniência, firmado com a Secretaria de Direito Econômico nos termos do art. 35-B e 35-C, da Lei $n^{\circ}$ 8.884, de 1994, deverão constar as seguintes cláusulas e condições: (...) VIII - declaração do beneficiário de que não esteve à frente da conduta infracionária, que não promoveu ou organizou a cooperação na infração, dirigido a atividade dos demais co-autores ou ainda que tenha coagido alguém a cometê-la."
} 
maneira que for, aquele que apresentar papel diferenciado no cartel estará impedido de celebrar acordo de leniência.

Não é demais ressaltar que importante observação sobre o tema foi registrada na Cartilha de combate a cartéis e programa de leniência. De acordo com as ressalvas nela contidas,

\begin{abstract}
“A SDE reconhece que, em muitos cartéis, não é possível identificar um líder. $\mathrm{O}$ mero fato de uma empresa ter agendado uma reunião ou mantido arquivos do cartel não necessariamente a desabilita como potencial beneficiária do Acordo de Leniência. Além disso, não haverá um líder do cartel se duas ou mais partes desempenharam papéis equivalentes no funcionamento da prática, nenhuma tendo se sobressaído em sua organização. Por fim, o fato de uma empresa ser a líder de mercado não significa, necessariamente, que seja a líder do cartel. ${ }^{314}$
\end{abstract}

Assim como ocorre nos programas de outros países, um eventual candidato que não se qualificar para a celebração do acordo de leniência em relação à determinada conduta (seja porque foi o segundo a se candidatar, seja por ter sido considerado como estado à frente da conduta infracionária) também poderá receber todos os benefícios da leniência, é o chamado "leniência plus".

Agora, para que o abrandamento da penalidade ocorra, é substancial que o candidato forneça informações relevantes acerca de outro cartel e cumpra com os demais requisitos previstos para o Programa de Leniência.

Para tanto, a Lei $n^{\circ} 8.884 / 94$ prevê, em seu artigo $35-B, \S 7^{\circ}$ que

“[...] a empresa ou pessoa física que não obtiver, no curso de investigação ou processo administrativo, habilitação para a celebração do acordo de que trata este artigo, poderá celebrar com a SDE, até a remessa do processo para julgamento, acordo de leniência relacionado a uma outra infração, da qual não tenha qualquer conhecimento prévio à Secretaria."

\footnotetext{
${ }^{314}$ BRASIL. MINISTÉRIO DA JUSTIÇA. SECRETARIA DE DIREITO ECONÔMICO. Cartilha sobre combate a cartéis e programa de leniência. P. 29.
} 
Todavia, o benefício concedido pela Secretaria de Direito Econômico resume-se ao âmbito administrativo no que tange à primeira conduta, eis que o legislador determinou expressamente que o "[...] infrator se beneficiará da redução de um terço da pena que lhe for aplicável naquele processo, sem prejuízo da obtenção de que trata o inciso I do $\$ 4^{o}$ deste artigo em relação à nova infração denunciada [...]", 315

O objetivo da "leniência plus" é incentivar empresas e pessoas investigadas a levar em consideração a possibilidade de se habilitarem junto à Secretaria de Direito Econômico a um acordo de leniência com relação a todos os seus mercados de atuação. Urge mencionar que para fazer jus aos benefícios com relação à primeira conduta noticiada, o candidato deve denunciar o segundo cartel antes que o primeiro seja levado ao CADE para julgamento final.

\subsubsection{Escorço histórico}

As origens do acordo de leniência remontam ao Programa de Leniência (leniency program) instituído nos Estados Unidos da América em 1978 pelo Departamento de Justiça. $^{316}$ o qual permitia que qualquer integrante de cartel $^{317}$ celebrasse acordo com a autoridade antitruste; mas isto, desde que fosse o primeiro componente a delatar o conluio e antes mesmo de iniciada qualquer investigação, sendo, pois, beneficiado com a concessão de "anistia" (amnesty) penal, isto é, não seria permitida qualquer acusação criminal contra ele em relação à conduta antitruste praticada e das sanções pecuniárias. ${ }^{318}$ O cumprimento das exigências legais para a celebração do acordo não garantia a anistia, porquanto a concessão dos benefícios não era automática e estava sujeita à

\footnotetext{
315 “[...] Artigo 35-B, (...) $\S 8^{\circ}$. Em seu $\S 4^{\circ}$, inciso I, assim restou previsto: "A celebração de acordo de leniência não se sujeita à aprovação do CADE, competindo-lhe, no entanto, quando do julgamento do processo administrativo, verificado o cumprimento do acordo: I - decretar a extinção da ação punitiva da administração pública em favor do infrator, nas hipóteses em que a proposta do acordo tiver sido apresentada à SDE sem que essa tivesse conhecimento prévio da infração noticiada; [...]"

${ }^{316}$ Nos Estados Unidos da América, compete ao Departamento de Justiça (Department of Justice) a defesa da concorrência.

317 Conforme Wouter P. J. WiLS, membro da Comissão Europeia, o Corporate Leniency Policy e o Individual Leniency Policy aplicam-se apenas a casos de cartel, pois, ainda que a legislação antitruste norteamericana (Sherman Act) preveja outros ilícitos concorrenciais, o Departamento de Justiça limita-se a instaurar investigações e processo criminal em casos de cartel, tais como: fraude em licitações, divisão de mercado e de clientes entre concorrentes e fixação de preços.

${ }^{318}$ HARRINGTON JR.; JOSEPH E.; CHEN, Joe. The impact of the corporate leniency program on cartel formation and the cartel price path.
} 
discricionariedade da Divisão Antitruste do Departamento de Justiça norte-americano, órgão responsável especificamente pela apuração de condutas anticompetitivas.

Essa insegurança jurídica comprometeu demasiadamente a eficácia do acordo de leniência, o que se comprova pelo fato de, entre 1978 e 1993, a média ter sido de um acordo celebrado por ano nos Estados Unidos da América ${ }^{319}$ e pelo fato de, nesse mesmo período, o Departamento de Justiça não ter conseguido levar aos tribunais norteamericanos nem mesmo um único caso de cartel internacional utilizando-se do programa. $^{320}$

Reestruturado em agosto de 1993, o programa de "lenidade" dos Estados Unidos da América, reestruturado em agosto de 1993, ganhou os contornos mais agressivos do chamado Programa de Leniência Corporativa (Corporate Leniency Policy, Corporate Amnesty Policy ou Corporate Immunity Policy). ${ }^{321}$ Os benefícios foram estendidos aos potenciais delatores, sendo impostas três novas formas de abordagem de investigação e punição de cartéis:

- Concessão automática de leniência à empresa, desde que a mesma satisfaça seis requisitos necessários. ${ }^{322}$

- $\quad$ Possibilidade de leniência, ainda que a cooperação se promova após ter início o procedimento investigatório. ${ }^{323}$

${ }^{319}$ RODAS, João Grandino. Acordos de leniência em Direito Concorrencial: práticas e recomendações. P. 23.

${ }^{320}$ HAMMOND, Scott D. Detecting and deterring cartel activity through an effective leniency program. P. 01.

${ }^{321}$ É, então, possível usar os termos anistia e imunidade como sinônimos para tratar de normas ou programas de leniência. Cf. VILELA, Juliana Girardelli. Op. cit., p. 207.

${ }^{322}$ VLADIMIR SPÍNDOLA SILVA ressalta que esses requisitos são imprescindíveis, sendo eles: (a) Ineditismo na denúncia fornecida ao órgão antitruste. (b) Após a denúncia, que a empresa cesse sua participação na prática ilícita. (c) Necessidade de cooperação total, por parte da empresa que delatou o fato, no inter-regno das investigações. (d) $\mathrm{O}$ crime denunciado deve ser um ato da própria empresa e não atos isolados de funcionários ou executivos da mesma. (e) Possibilidade de a empresa indenizar as partes lesadas. $(f)$ Necessidade de a empresa delatora não ter coagido outras empresas a participarem da atividade ilegal, bem como não ter liderado ou incentivado a prática infratora. (SILVA, Vladimir Spindola. O instituto da leniência no direito antitruste norte-americano. Pp. 328/329). Todos esses requisitos estão previstos na Política de leniência corporativa.

${ }^{323}$ VLADIMIR SPÍNDOLA SILVA prossegue ressaltando que pode ocorrer da empresa delatora não preencher os seis requisitos necessários. Ainda assim, ela terá direito à leniência, independente de a delação ocorrer antes ou após o início das investigações, contanto que preencha sete requisitos: (a) Ser a primeira empresa a apresentar a denúncia, e que esta a habilite a ingressar no Programa de Leniência. (b) Necessidade de o órgão antitruste não ter provas contra a empresa delatora no momento em que esta decide fazer a denúncia. (c) Após a denúncia, que a empresa cesse sua participação na atividade ilícita. (d) Necessidade de cooperação 
- Todos os membros que cooperem (funcionários, diretores e executivos, atuais ou já desligados da empresa) estarão protegidos do processo criminal. ${ }^{324}$

A média aumentou para mais de um acordo celebrado por mês, especificamente entre outubro de 2002 e março de 2003, atingindo o índice de três acordos por mês. ${ }^{325}$

A diretriz perquirida sintetizava-se na seguinte expressão: oferecer o que as empresas não possam recusar. ${ }^{326}$

Em agosto do ano seguinte, o Departamento de Justiça dos Estados Unidos da América instituiu um novo Programa de Leniência para pessoas físicas que se apresentassem às autoridades de modo independente, ou seja, não fazendo parte do acordo realizado institucionalmente por alguma empresa em função do cargo que ocupassem, oferecendo-lhes "anistia" penal. ${ }^{327}$

total por parte da empresa que delatou o fato criminoso durante o inter-regno das investigações. (e) Possibilidade de a empresa indenizar a parte lesada (restitution clause). ( $f$ ) $\mathrm{O}$ crime denunciado deve ser um ato da própria empresa, e não atos isolados de seus funcionários ou executivos. ( $g$ ) A Divisão Antitruste deve determinar que a concessão de leniência para esta empresa não seja injusta com outros; para tanto, deve considerar a natureza da atividade ilegal, isto é, do crime antitruste, além do papel que a empresa denunciante desempenhou na atividade ilícita, bem como o momento em que decidiu apresentar-se ao órgão responsável pela punição. (SILVA, Vladimir Spindola. Idem, ibidem, p. 329).

${ }^{324}$ No original: “Leniency for Corporate Directors, Officers, and Employees: If a corporation qualifies for leniency under Part A, above, all directors, officers, and employees of the corporation who admit their involvement in the illegal antitrust activity as part of the corporate confession will receive leniency, in the form of not being charged criminally for the illegal activity, if they admit their wrongdoing with candor and completeness and continue to assist the Division throughout the investigation." Tradução livre: "Leniência para diretores, executivos e funcionários de uma empresa: Se uma empresa qualificar-se pela Parte A acima [Leniência anterior ao início de uma investigação], todos os seus diretores, executivos e funcionários que admitam seu envolvimento na atividade antitruste ilegal como parte da confissão da empresa receberão a leniência, de modo que não serão processados criminalmente pela atividade ilegal, desde que admitam suas irregularidades com franqueza e plenitude e continuem a ajudar a Divisão ao longo da investigação." (ESTADOS UNIDOS DA AMÉRICA. DEPARTMENT OF JUSTICE. Corporate Leniency Policy, grifos no original).

${ }^{325}$ GRIFFIN, James M. A summary overview of the antitrust division's criminal enforcement program. The Modern Leniency Program After Ten Years.

${ }^{326}$ SPRATLING, Gary G. Making companies an offer they shouldn't refuse.

327 O Departamento de Justiça norte-americano assim publicou em seu sítio: "The Division today announces a new Leniency Policy for Individuals that is effective immediately and applies to all individuals who approach the Division on their own behalf, not as part of a corporate proffer or confession, to seek leniency for reporting illegal antitrust activity of which the Division has not previously been made aware. Under this Policy, "leniency" means not charging such an individual criminally for the activity being reported." (ESTADOS UNIDOS DA AMÉRICA. DEPARTMENT OF JUSTICE. The modern leniency program fter ten years). Tradução livre: “A Divisão anuncia hoje uma nova Política de Leniência para Pessoas Físicas que têm eficácia imediata e se aplica a todos os indivíduos que se apresentarem individualmente para a Divisão, não como parte de uma proposta ou confissão de uma empresa, buscando leniência por relatar uma atividade antitruste ilegal da qual a Divisão ainda não tenha conhecimento. Nesta Política, 'leniência' significa não processar criminalmente o indivíduo pela atividade delatada.” 
Com essa nova política, a leniência passa a ser oferecida para aquele indivíduo que delatar às autoridades antitruste uma atividade anticompetitiva ilegal, desde que preenchidas três condições:

- A Divisão ainda não tenha recebido nenhuma informação sobre a conduta ilegal relatada.

- O candidato a leniente admita suas irregularidades com franqueza e plenitude e coopere permanentemente com a Divisão ao longo da investigação.

- O candidato a leniente não tenha coagido outra empresa a participar da atividade ilícita e não tenha liderado ou iniciado a conduta anticompetitiva. ${ }^{328}$

Para aqueles indivíduos que não consigam se qualificar no Programa de Leniência nos termos previstos acima é oferecida uma "imunidade informal ou estatutária" (statutory or informal immunity) na esfera penal. Nesta hipótese, a Divisão Antitruste faz uma análise discricionária e casuística para conceder a leniência. ${ }^{329}$

Sobre os efeitos criminais do acordo de leniência norte-americano e sua extensão, o Modelo de Carta de Leniência Corporativa Condicional, elaborado pelo Departamento de Justiça com base nas diretrizes da política de leniência, prevê expressamente

\footnotetext{
${ }^{328}$ Esses requisitos estão previstos no sítio do Departamento de Justiça dos Estados Unidos da América: "A. Requirements for Leniency for Individuals: Leniency will be granted to an individual reporting illegal antitrust activity before an investigation has begun, if the following three conditions are met: 1. At the time the individual comes forward to report the illegal activity, the Division has not received information about the illegal activity being reported from any other source; 2. The individual reports the wrongdoing with candor and completeness and provides full, continuing and complete cooperation to the Division throughout the investigation; and 3. The individual did not coerce another party to participate in the illegal activity and clearly was not the leader in, or originator of, the activity." (ESTADOS UNIDOS DA AMÉRICA. DEPARTMENT OF JUSTICE. Leniency policy for individuals, grifos no original).

${ }^{329}$ Assim foi publicado pelo Departamento de Justiça norte-americano: “[...] B. Applicability of the Policy: Any individual who does not qualify for leniency under Part A of this Policy will be considered for statutory or informal immunity from criminal prosecution. Such immunity decisions will be made by the Division on a case-by-case basis in the exercise of its prosecutorial discretion." Idem, ibidem. Tradução livre: "[...] $\underline{\mathbf{B}}$. Aplicabilidade da Política: Qualquer indivíduo que não se qualificar para leniência pela Parte A desta Política será aceito para imunidade informal ou estatutária com relação à persecução penal. Essas decisões sobre imunidade serão tomadas pela Divisão a partir de um critério casuístico no exercício de sua discricionariedade persecutória." (ESTADOS UNIDOS DA AMÉRICA. DEPARTMENT OF JUSTICE. Leniency policy for individuals, grifos no original).
} 
"Pursuant to that policy, the Antitrust Division agrees not to bring any criminal prosecution against Applicant for any act or offense it may have committed prior to the date of this letter in connection with the anticompetitive activity being reported. The commitments in this paragraph are binding only upon the Antitrust Division, although, upon request of Applicant, the Division will bring this Agreement to the attention of other prosecuting offices or administrative agencies." 330

É clara, portanto, a proibição de persecução penal contra o leniente no que se refere a qualquer ato conexo à atividade ilícita antitruste delatada às autoridades, desde que praticado anteriormente à celebração do acordo.

Além disso, não há restrição dos efeitos do acordo à área penal, pois o modelo de leniência norte-americano possibilita que os seus termos sejam apresentados para órgãos acusatórios de outras esferas, isto é, “[...] other prosecuting offices or administratives agencies [...]”, em atendimento à requisição do próprio leniente. Nessas hipóteses, não há garantia alguma ou compromisso de concessão de "anistia" por parte das autoridades.

Ainda sobre os efeitos desse acordo, insta destacar que embora o Programa de Leniência dos Estados Unidos da América apresente uma relativa segurança jurídica ao leniente, os próprios modelos de cartas de leniência trazem expressamente a discricionária possibilidade de revogação da anistia penal:

"If at any time before Applicant is granted unconditional leniency the Antitrust Division determines that Applicant (1) contrary to its representations in paragraph 1 of this Agreement, is not eligible for leniency or (2) has not provided the cooperation required by paragraph 2 of this Agreement, this Agreement shall be void, and the Antitrust Division may revoke the conditional acceptance of Applicant into the Corporate Leniency Program." 331

330 Tradução livre: "De acordo com essa política, a Divisão Antitruste concorda em não levar adiante persecução penal alguma contra o leniente em relação a atos conexos à atividade anticompetitiva delatada que ele tenha cometido anteriormente à data deste acordo. Os compromissos contidos neste parágrafo estão vinculados apenas à Divisão Antitruste, apesar de, a pedido do leniente, a Divisão poder levar este acordo ao conhecimento de outros escritórios de acusação ou agências administrativas." (ESTADOS UNIDOS DA AMÉRICA. DEPARTMENT OF JUSTICE. Model corporate conditional leniency letter).

${ }^{331}$ Tradução livre: "Se a qualquer tempo, antes de o leniente receber a leniência incondicional, a Divisão Antitruste determinar que o leniente (1) contrariamente aos termos do parágrafo 1 deste acordo não for elegível para a leniência ou (2) não providenciou a cooperação exigida no parágrafo 2 deste acordo, este deve 
É notável a preocupação das autoridades em inserir no acordo a concordância do leniente com a revogação da concessão da anistia, de maneira que não lhe é permitido requerer a revisão judicial desta decisão até que seja formulada uma acusação de envolvimento na prática ilegal relatada. ${ }^{332}$

Afora isso, nesses casos em que a persecução criminal se concretiza, o modelo de acordo de leniência permite que a Divisão Antitruste se utilize de "[...] any documents, statements, or other information provided to the Division at any time pursuant to this Agreement by Applicant or by any of its current [or former] directors, officers, or employees $[\ldots], 333$

É importante registrar que todas essas cláusulas que relativizam a segurança jurídica do Programa de Leniência corporativa estão igualmente previstas no Modelo de Carta de Leniência Individual Condicional. ${ }^{334}$ Todavia, ainda assim, a política de leniência norte-americana revelou-se um grande sucesso.

Segundo IBRAHIM ACÁCIO ESPíRITo SOBRAL, o sucesso do programa derivou de três fatores preponderantes: a ameaça de aplicação de penalidades severas, o temor da punição e a transparência na política de atuação da agência.

O primeiro fator consiste na escolha vantajosa e aconselhável pela colaboração com as autoridades, na medida em que a participação no cartel é considerada crime, havendo risco efetivo de prisão. Mister a presença de penas que intimidem e inibam a formação do cartel. A receita norte-americana para o sucesso tem como pressuposto que os riscos envolvidos na formação e atuação do cartel precisam ser maiores que os eventuais benefícios econômicos das condutas ilícitas intentadas ou consumadas, sob pena de serem

ser invalidado e a Divisão Antitruste pode revogar a aceitação condicional do leniente no Programa de Leniência Corporativa." (Idem, ibidem).

332 Cf. "Applicant understands that the Antitrust Division's Leniency Program is an exercise of the Division's prosecutorial discretion, and Applicant agrees that it may not, and will not, seek judicial review of any Division decision to revoke its conditional leniency unless and until it has been charged by indictment or information for engaging in the anticompetitive activity being reported." Tradução livre: "O leniente entende que o Programa de Leniência da Divisão Antitruste é um exercício de discricionariedade persecutória e ele concorda em não poder requerer, e não o fará, a revisão judicial de qualquer decisão da Divisão de revogação de sua leniência condicional, a não ser que ou até que seja feita a acusação por indiciamento ou informação de envolvimento na atividade ilícita delatada." (Idem, ibidem).

333 Tradução livre: "[...] quaisquer documentos, depoimentos ou outras informações referentes a este acordo entregues à Divisão a qualquer tempo pela empresa leniente ou por qualquer um de seus diretores, executivos ou funcionários, atuais ou já desligados da empresa." (Idem ibidem).

334 ESTADOS UNIDOS DA AMÉRICA. DEPARTMENT OF JUSTICE. Model individual conditional leniency letter. 
vistas como apenas um custo a mais na estratégia corporativa das empresas e de seus dirigentes. Os incentivos oferecidos pelo Programa de Leniência devem ser suficientemente atraentes.

Um outro fator a ser considerado reside na credibilidade da agência promotora da livre concorrência. Deve haver um risco significativo de apuração e punição da conduta ilícita pela autoridade competente. Diante de um clima de ansiedade, tensão e desconfiança, é inevitável a inibição de futuros cartéis e o desmantelamento dos já existentes.

É primordial a transparência na conduta da agência, transmitindo a segurança e confiança necessárias à participação no programa. A contrapartida governamental deve ser transparente e previsível para estimular a delação.

Na visão de SCOTT D. HAMMOND, este último pilar é crucial, pois

“[...] prospective amnesty applicants come forward in direct proportion to the predictability and certainty of whether they will be accepted into the program. Uncertaint in the qualification process will kill an amnesty program..,335

Em termos de inovações, o Corporate Leniency Policy trouxe a possibilidade de um amnesty plus. ${ }^{336}$ As autoridades norte-americanas, ao perceberem que as empresas participantes de um cartel faziam parte de outros cartéis em mercados distintos, passaram a oferecer acordos àquelas já formalmente investigadas com relação a outros cartéis.

Deste modo, ainda que uma empresa não pudesse ser beneficiada com o perdão total da pena decorrente do primeiro cartel sob investigação, a prestação de informações em relação à participação em um segundo cartel levaria ao afastamento de condenação no que se refere a este, além da redução da pena com relação ao primeiro (plus). ${ }^{337}$

335 Tradução livre: “[...] os eventuais requerentes de leniência apresentam-se em proporção direta à previsibilidade e à certeza de saber se eles serão aceitos no programa. A incerteza no processo de qualificação matará um programa de leniência." (HAMMOND, Scott D. Fighting cartels - why and how? Lessons common to detecting and deterring cartel activity. P. 5).

336 Tradução livre: anistia adicional.

${ }^{337}$ PAOLO ZUPO MAZZUCATO registra que "Graças a essa iniciativa o número de condenações aumentou consideravelmente e, de 40 cartéis internacionais revelados, mais da metade ocorreu em virtude da Leniency Plus. Impende também ressaltar o 'efeito dominó' verificado em alguns episódios, quando a descoberta de 
Com essas mudanças, o Amnesty Program transformou-se no mais eficiente instrumento de investigação para descobrir e combater os cartéis. Logo, os efeitos positivos dessas novas medidas vieram à tona:

\begin{abstract}
"O total de multas aplicadas às empresas condenadas entre os anos de $1976 \mathrm{e}$ 1996 (intervalo de 20 anos) equivale ao total de multas aplicadas somente nos anos de 1997 e 1998 (intervalo de 2 anos). A média de celebração de acordos que de 1978 a 1993 foi de uma por ano, subiu para uma por mês a partir de 1994. Entre os meses de outubro de 2002 e março de 2003, a média foi de três celebrações por mês." 338

"De 1997 a 2004, foram aplicadas multas que somam mais de US\$ 2,5 bilhões por práticas anticompetitivas, sendo que mais de $90 \%$ desse total tiveram o respaldo de informações obtidas via programa de leniência. Igualmente, dos mais de cinqüenta processos que investigam cartéis internacionais, com atividades nos seis continentes, mais da metade deles foram iniciados ou beneficiados por informações recebidas via membro-delator do cartel.”339
\end{abstract}

Grandes exemplos de acordos de leniência que levaram à condenação dos participantes de cartel, à exceção do membro delator, são: cartel no mercado de memória do computador, cartel no mercado de eletrodos de grafite, cartel no mercado de obras de arte e cartel no mercado de construção naval. ${ }^{340}$

Influenciados pelos resultados da política antitruste norte-americana, vários órgãos de defesa da concorrência em outros países adotaram uma política de leniência similar, objetivando o desmantelamento dos cartéis, dentre eles: Reino Unido, Alemanha, França,

uma infração conduz a outra sucessivamente. O 'Cartel da Lisina' encaminhou a Division ao 'Cartel do Ácido Cítrico', que, por sua vez, levou ao cartel do Gluconato de Sódio', que resultou na investigação do 'Cartel do Eritorbato de Sódio' e, finalmente, no 'Cartel do Maltol'. Ao todo, como saldo dos cinco processos interconectados, 10 companhias e 11 indivíduos de sete diferentes países foram condenados e pagaram mais de US\$ 225 milhões." (MAZZUCATO, Paolo Zupo. Acordo de leniência. A política econômica de combate a cartéis. Pp. 52/53).

${ }^{338}$ ANDRADE FILHO, Arthur Guerra de. O acordo de leniência como instrumento para o combate a cartéis. Pp. 14/15.

${ }^{339}$ SPRATLING, Gary R. Cornerstones of an effective leniency program (2004). Apud RODAS, João Grandino. Acordos de leniência em direito concorrencial: práticas e recomendações. P. 24.

${ }^{340}$ RODAS, João Grandino. Acordos de leniência em direito concorrencial: práticas e recomendações. Pp. $24 / 25$. 
Canadá e Irlanda. ${ }^{341}$ À guisa de exemplo, em 1996, a União Europeia instituiu o programa denominado Europe Union leniency program.

Ao seguir a tendência mundial, o Brasil adotou o instituto - “[...] pilar fundamental da Política Nacional de Proteção da Ordem Econômica [...]"342 - como forma de combater o abuso do poder econômico que se tornava cada vez mais frequente. Não obstante a ideia fosse inédita no País, instrumento semelhante já era visto em nosso sistema legislativo. Diversas formas de delação premiada vinham sucessivamente sendo inseridas em nosso ordenamento jurídico, ${ }^{343}$ ofertando benefícios mais restritos em confronto com o acordo de leniência. Enquanto a maioria das modalidades de delação premiada afigura-se como causa de diminuição de pena, o programa de "suavização" caracteriza-se como possível instrumento de extinção da punibilidade, fato este que o torna, certamente, mais atraente aos olhos dos supostos infratores. ${ }^{344}$

No País, o primeiro acordo de leniência foi firmado em 8 de outubro de 2003, após a realização de duas operações de busca e apreensão naquele ano. Um ex-integrante de um suposto cartel delatou às autoridades antitruste um esquema elaborado por um grupo de 21 empresas, três entidades e 30 pessoas físicas do setor de segurança privada do Rio Grande do Sul para fraudar licitações e combinar preços. ${ }^{345}$

O alvo do cartel era licitações organizadas principalmente pela Superintendência Regional da Receita Federal do Rio Grande do Sul e pela Secretaria Municipal de Saúde de Porto Alegre. Com o intuito de obter imunidades administrativa e penal, o beneficiário do Programa de Leniência apresentou provas diretas das fraudes às licitações, incluindo relatos de empresas e documentos trocados entre os membros do cartel.

O acordo foi celebrado entre a empresa Vigilância Antares Ltda. - mediante seu proprietário Rubem Baz Oreli e o seu funcionário Alexandre Luzardo da Silva - e a Secretaria de Direito Econômico do Ministério da Justiça (SDE), constando como

\footnotetext{
${ }^{341}$ GRIFFIN, James M. Op. cit.

${ }^{342}$ Artigo 61, da Portaria do Ministério da Justiça n ${ }^{\circ}$ 04, de 05 de janeiro de 2006.

${ }^{343}$ Apenas a título de referência: art. $8^{\circ}$, parágrafo único, da Lei n ${ }^{\circ}$ 8.072/90 (Lei dos Crimes Hediondos); artigo $6^{\circ}$ da Lei $n^{\circ}$ 9.034/95 (Lei do Crime Organizado); artigo 159 do Código Penal (crime de extorsão mediante sequestro); artigo 14 da Lei $n^{\circ}$ 9.605/98 (Lei de Crimes Ambientais); artigo $1^{\circ}$, $\S 5^{\circ}$, da Lei $n^{\circ}$ 9.613/98 (Lei de Lavagem de Capitais) e artigo 41 da Lei no 11.343/06.

${ }^{344}$ Cf. CASTELO BRANCO, Fernando. Reflexões sobre o acordo de leniência: moralidade e eficácia na apuração dos crimes de cartel. P. 146.

${ }^{345}$ VIEIRA, Caroline Sanselme. Op. cit., p. 91.
} 
intervenientes a Secretaria de Acompanhamento Econômico do Ministério da Fazenda (SEAE), o Ministério Público Federal e o Ministério Público Estadual do Rio Grande do Sul. $^{346}$

Ao final, em 2007, o CADE impôs multas que variaram de $15 \%$ a $20 \%$ do faturamento bruto de 2002 a 16 empresas pela prática de cartel (superiores a R $\$ 40$ milhões). Administradores das empresas condenadas e três associações de classe também foram condenados e multados pelo CADE. O beneficiário do Programa de Leniência não recebeu sanção alguma na esfera administrativa, sendo extinta sua punibilidade no âmbito criminal, porquanto reconhecido o cumprimento das condições impostas no acordo. ${ }^{347}$

Desde a sua instauração, o modelo brasileiro do Programa de Leniência vem recebendo aplausos de inúmeras autoridades antitruste de todo o mundo e o CADE já reconheceu, em diversas ocasiões, que este Programa é um dos instrumentos de

\footnotetext{
${ }^{346}$ Segundo o relato dos delatores sobre o cartel, as empresas participantes determinariam a empresa vencedora das licitações para prestação de serviços de vigilância em reuniões que ocorriam no sindicato da classe sempre às segundas-feiras. A estratégia consistia na combinação de todos apresentarem, nas concorrências públicas, preços superiores aos da empresa "escolhida" previamente por eles para ser a vencedora. Dentre elas, haveria constantemente uma que não apresentaria todos os documentos exigidos no edital, de maneira que seria invariavelmente inabilitada. Os delatores narram, ainda, a participação de advogados na negociação com os elaboradores dos editais no que tange à inclusão de requisitos adicionais, de forma a impedir a entrada de novas empresas estranhas ao ajuste. (VIEIRA, Caroline Sanselme. Idem, ibidem, p. 91).

${ }^{347}$ A título de ilustração, segue quadro demonstrativo das multas aplicadas nesse caso:
}

\begin{tabular}{l|r}
\hline Empresa & Multa (em R\$) \\
\hline Rudder Segurança Ltda. & $7.992 .045,46$ \\
Empresa Brasileira de Vigilância - EBV & $2.331 .231,69$ \\
Empresa Portoalegrense de Vigilância Ltda. EPAVI & $2.301 .395,58$ \\
Mobra Serviço de Segurança Ltda. & $2.107 .654,43$ \\
Segurança e Transporte de Valores Panambi Ltda. & $2.252 .378,02$ \\
Protevale Vigilância e Segurança Ltda. & $451.792,16$ \\
Reação Segurança e Vigilância Ltda. & $727.442,86$ \\
Rota Sul Empresa de Vigilância Ltda. & $1.788 .096,50$ \\
Seltec Vigilância Especializada Ltda. & $1.061 .167,04$ \\
Vigilância Pedrozo Ltda. & $9.171 .684,11$ \\
Protege Serviços de Vigilância Ltda. & $2.481 .983,50$ \\
\hline
\end{tabular}

As empresas Ondrepsb Serviços de Guarda e Vigilância Ltda. e Secure Sistemas de Segurança Ltda. também foram condenadas a $15 \%$ de seu faturamento bruto, porém nenhuma delas apresentou espontaneamente estes valores, de maneira que foi instaurado auto de infração para essa apuração.

(Cf. CÓRDOVA, Danilo Ferraz; LOPES, Mariana Rebuzzi Sarcinelli. Política de combate aos cartéis: os acordos de leniência, o Termo de Compromisso de Cessação e a Lei nº 11.482/2007. P. 81). 
investigação mais efetivos para se prevenir e punir cartéis. Aproximadamente 23 acordos de leniência foram celebrados até hoje, inclusive com membros de cartéis internacionais. ${ }^{348}$

\subsubsection{Outras experiências estrangeiras}

Como visto em tópico anterior, os Estados Unidos da América foram os pioneiros na adoção da política de leniência em 1978. Ao seguir essa experiência, vários outros países passaram a lançar mão de programas de leniência com o intuito de obter provas de práticas anticoncorrenciais, cada qual com as suas próprias características em consonância com as necessidades previstas pelas autoridades de cada nação.

É o que será abordado neste subitem, apresentando o Programa de Leniência adotado por alguns países, suas semelhanças e divergências.

\subsubsection{Comunidade Europeia}

Ao suceder os Estados Unidos da América nessa experiência, a Comunidade Europeia adotou o programa pela primeira vez em 1996.

Ao contrário do modelo norte-americano, que concede anistia apenas à primeira empresa que trair o cartel e delatá-lo à autoridade antitruste, o programa europeu original seguia uma abordagem de escalonamento das multas:

“(a) se a empresa for a primeira a trair e a delatar o cartel antes de qualquer investigação, garantirá para si uma redução da multa na ordem de 75 a 100\%

${ }^{348}$ De acordo com informações obtidas perante a Secretaria de Direito Econômico, os acordos de leniência foram firmados ao longo dos anos da seguinte maneira:

\begin{tabular}{c|c|c|c}
\hline Ano & $\begin{array}{c}\mathbf{N}^{\mathbf{o}} \text { de } \\
\text { Acordos }\end{array}$ & Ano & $\begin{array}{c}\mathbf{N}^{\mathbf{0}} \text { de } \\
\text { Acordos }\end{array}$ \\
\hline 2003 & 1 & 2008 & 2 \\
2004 & 1 & 2009 & 4 \\
2005 & 1 & 2010 & 8 \\
2006 & 4 & 2011 & 1 \\
\hline 2007 & 1 & TOTAL & $\mathbf{2 3}$ \\
\hline
\end{tabular}


do valor total; (b) se a empresa for a primeira a trair e a delatar o cartel, mas a investigação já estiver em curso, a redução da multa será em torno de 50 a $75 \%$ do valor total; e (c) se a empresa não for a primeira a trair e a delatar o cartel, mas colaborar com a investigação e não contestar as alegações de que é alvo, garantirá para si uma redução da multa que pode ser de $10 \%$ a $50 \%$ do valor total. A exata redução do valor das multas fica sob a discricionariedade da Comissão Européia." 349

Ainda que o parâmetro de redução das multas fosse determinado pela Comissão Europeia, a sua exata diminuição ficaria a critério das autoridades europeias nacionais.

Os resultados atingidos pelo Leniency Notice foram satisfatórios, alcançando multas que totalizaram 2.240 bilhões de euros entre 1996 a 2002, sendo apreciados 16 casos de cartéis. ${ }^{350}$ Até outubro de 2003, ao menos 100 empresas já haviam procurado a Comissão com vistas a firmar um acordo de leniência. ${ }^{351}$

Entretanto, em 2002, o Leniency Notice passou por uma ampla revisão, seguindo as diretrizes do modelo norte-americano, ${ }^{352}$ de maneira que a discricionariedade da Comissão Europeia diminuiu, aumentando, em contrapartida, a transparência e as possibilidades para uma empresa conquistar a imunidade plena. ${ }^{353}$ A partir de então, a primeira empresa que delatasse uma formação de cartel às autoridades antes do início de uma investigação ou durante a mesma - conquanto preenchidos determinados requisitos ${ }^{354}$ - receberia a imunidade total.

\footnotetext{
${ }^{349}$ MOREIRA, Eduardo Ataide de Souza; PEÑALOZA, Rodrigo. Programas de leniência, corrupção e o papel da corregedoria da autoridade antitruste.

${ }^{350}$ A primeira empresa a cooperar com a Comissão Europeia e receber total imunidade foi a francesa Aventis S/A, após relatar a sua participação no cartel das vitaminas A e E, durante o período de 1986 a 1999. Ao decidir colaborar com as autoridades antitruste, a Aventis evitou a condenação ao pagamento de pesadas multas. As demais participantes do cartel foram multadas em 850 milhões de euros. (VILELA, Juliana Girardelli. Op. cit., p. 210).

${ }^{351}$ LEVY, Nicholas; O'DONOGHUE, Robert. The EU leniency programme comes of age. P. 75.

${ }^{352}$ EUROPA. EUROPEAN COMMISION. Comission notice on the non-imposition or reduction of fines. OJ 1996 C 207/04, de 18.07.96. Commission notice on the non-imposition or reduction of fines. OJ 2-2 C 45/3, de 19.02.02.

${ }^{353}$ No programa de leniência de 1996, das 80 firmas que celebraram o acordo com a Comissão Europeia, somente três atingiram a imunidade total e apenas duas conseguiram redução substancial de suas multas (de $80 \%$ a 90\%). (MOREIRA, Eduardo Ataide de Souza; PEÑALOZA, Rodrigo. Op. cit.).

${ }^{354}$ São eles: oferecer provas contundentes acerca da existência do cartel, aceitar cooperar com o órgão antitruste de forma irrestrita, abandonar as antigas condutas ilícitas e não ter forçado a participação de quaisquer empresas no cartel. (RODAS, João Grandino. Acordos de leniência em direito concorrencial: práticas e recomendações. P. 25).
} 
Além disso, com o programa de 2002, não mais subsiste a exigência de prova decisiva com relação à prática do cartel, restando excluída do acordo apenas aquela empresa que tenha exercido coerção sobre as demais para participar na conduta ilícita, ou tenha sido a instigadora ou a líder (the instigator ou the leader). Esta última exigência significa que só pode haver uma empresa líder ou instigadora, de modo que se nenhuma participante se enquadrar nessa figura, todas serão passíveis de celebrar o acordo, aumentando o seu alcance.

Convém assinalar que o programa continuou a permitir que outros membros do cartel (latecomers) se beneficiassem de reduções nas sanções, mesmo após a delação de outro participante. ${ }^{355}$ Consoante as autoridades europeias, as alterações no Programa de Leniência tornaram-no bem mais atraente, pois, enquanto nos seis anos de vigência do programa original foram apresentadas à Comissão 80 propostas de acordo, entre 2002 e 2006, foram 167, das quais 87 eram requisições de imunidade plena e 80 de redução de multa. Além disso, dos 87 pedidos de imunidade plena, 50 foram concedidos pela Comissão, ao passo que, com o programa original, somente três empresas beneficiaram-se com a imunidade. ${ }^{356}$

Mesmo com essas alterações e após uma nova revisão levada a efeito no ano de $2006,{ }^{357}$ o programa europeu não se igualou ao norte-americano, persistindo algumas diferenças significativas. ${ }^{358}$ Apenas para citar as mais relevantes, no Leniency Notice, ainda

\footnotetext{
355 As reduções são as seguintes: de $30 \%$ a $50 \%$ de redução para o primeiro latecomer, de $20 \%$ a $30 \%$ de redução para o segundo latecomer e até $20 \%$ de redução para os demais membros do cartel que procurarem a Comissão para colaborar com as investigações. (RODAS, João Grandino. Acordos de leniência em direito concorrencial: práticas e recomendações. P. 25).

${ }^{356}$ Cf. EUROPA. EUROPEAN COMMISSION COMPETITION. Leniency.

357 Insta destacar que essas últimas alterações não trouxeram mudanças significativas ao programa de leniência europeu. As diretrizes de 2002 persistiram, de maneira que as novas disposições apenas complementaram com maiores detalhes a questão atinente à admissão das empresas no programa, na tentativa de trazer, ainda, mais transparência à proposta da Comissão (EUROPA. EUROPEAN COMMISSION. Commision notice on immunity from fines and reduction of fines in cartel cases. OJ 2006/C 298/11, de 08.12.2006).

${ }^{358}$ Ainda assim, é relevante mencionar que as multas impostas ao longo dos anos foram de grande expressão, como comprova o quadro a seguir:
}

Multas impostas a cartéis pela Corte de Julgamento Europeia no período entre 2006 e 2010

\begin{tabular}{l|r}
\hline Ano & Multa (em Euros) \\
\hline 2006 & 1.846 .385 .500 \\
2007 & 3.338 .427 .700 \\
2008 & 2.270 .012 .900 \\
2009 & 1.623 .384 .400 \\
2010 & 1.668 .904 .832 \\
\hline TOTAL & $\mathbf{1 0 . 7 4 7 . 1 1 5 . 3 3 2}$ \\
\hline
\end{tabular}


que a empresa não seja a primeira a delatar a formação do cartel, ela poderá se beneficiar com uma redução de multa, enquanto no programa norte-americano não existe essa possibilidade. Outra grande disparidade reside no fato de a imunidade automática, efetivada quando presentes todos os requisitos exigidos, não estar presente no programa europeu, apesar de a transparência ter aumentado.

$\mathrm{Na}$ realidade, o intuito das autoridades europeias ao realizarem novas modificações ao programa foi garantir maior celeridade ao processo de celebração do acordo. Uma das grandes preocupações foi esclarecer e explicitar os tipos de informações e provas que devem ser apresentadas às autoridades. ${ }^{359}$

Uma inovação desse programa adotado em 2006 foi a previsão da possibilidade de o candidato a leniente continuar participando do cartel se, de acordo com a Comissão, isso for necessário para preservar a integridade e confidencialidade das negociações do acordo de leniência.

Este novel programa também especifica que apenas será legitimado para a celebração do acordo aquele agente econômico que não tenha previamente destruído, falsificado ou ocultado informações e provas relacionadas ao cartel. Além disso, passa a permitir que o candidato que tenha coagido outras empresas a participarem da prática ilícita possa obter a redução da multa, caso coopere com as autoridades na forma prevista.

É interessante notar as dez maiores multas impostas a empresas envolvidas em cartéis (desde 1969):

\begin{tabular}{l|lr}
\hline Anos & Nome do Caso & Multa (em Euros) \\
\hline 2008 & Vidro de carro & 1.383 .896 .000 \\
2009 & Gás & 1.106 .000 .000 \\
2007 & Elevadores e escadas rolantes & 992.312 .200 \\
2001 & Vitaminas & 790.515 .000 \\
2007 & Aparelho de comutação de isolamento a gás & 750.712 .500 \\
2008 & Ceras para velas & 676.011 .400 \\
2010 & Acessórios para banheiro & 622.250 .782 \\
2006 & Borracha sintética & 519.050 .000 \\
2010 & Aço & 518.470 .750 \\
2007 & Vidro liso & 486.900 .000 \\
\hline
\end{tabular}

(EUROPA. EUROPEAN COMMISSION COMPETITION. Cartel statistics).

${ }^{359}$ Nesse sentido, o programa de leniência prevê a concessão de imunidade plena à empresa que forneça às autoridades informações e provas que viabilizem a execução de inspeções dirigidas (targeted inspection) pela Comissão ou que permitam o reconhecimento da violação ao artigo 81 do Tratado da União Europeia. Tais informações e provas devem consistir em um histórico de condutas (corporate statement) que forneça, entre outros dados: descrição detalhada da prática de cartel, incluindo seus objetivos, atividades e funções; o mercado relevante afetado e as estimativas dos efeitos produzidos pelo cartel, sua duração e a identificação das empresas e pessoas envolvidas na prática ilícita. (EUROPA. EUROPEAN COMMISSION. Commision notice on immunity from fines and reduction of fines in cartel cases. OJ 2006/C 298/11, de 08.12.2006). 
O atual Programa de Leniência europeu assegura a confidencialidade e impossibilidade de discovery ${ }^{360}$ das informações e declarações apresentadas às autoridades pelas empresas delatoras, visando preservar o interesse dos agentes econômicos pelo acordo, minimizando o risco de pagamento de vultuosas indenizações a consumidores e concorrentes prejudicados pelo cartel no âmbito civil. ${ }^{361}$

No que tange especificamente à aplicação de multas ou penas privativas de liberdade, a Comissão Europeia não tem jurisdição sobre as pessoas, ficando sob responsabilidade dos países, individualmente, a punição dos seus investigados, ao passo que nos Estados Unidos da América os infratores estão sujeitos à aplicação de sanções tão logo investigados e condenados. Da mesma forma, a conhecida cláusula de restituição (restitution clause) existente no programa estadunidense, concernente à obrigação da empresa beneficiada pela anistia indenizar as partes prejudicadas, não é aplicável à Comissão Europeia, ficando sob responsabilidade de cada um dos países europeus regulamentar a questão. ${ }^{362}$

No âmbito nacional, Alemanha, França, Irlanda, Holanda, Reino Unido, Áustria, Grécia, Portugal, Itália, Finlândia, República Tcheca, Bélgica, Bulgária, Chipre, Dinamarca, Estônia, Hungria, Letônia, Lituânia, Luxemburgo, Polônia, Romênia, Eslováquia, Espanha e Suécia ${ }^{363}$ já adotaram um Programa de Leniência. Em sua maioria, os países seguem as linhas gerais do programa comunitário, somando a elas diretrizes específicas sobre os reflexos do acordo na esfera penal. Agora, passar-se-á à análise de alguns deles.

\subsubsection{Reino Unido}

No Reino Unido, condutas anticompetitivas, como o cartel e o abuso de posição dominante no mercado, são consideradas infrações administrativas previstas nos Capítulos I e II do Competition Act 1998, bem como nos artigos 81 e 82 do Tratado da União

\footnotetext{
${ }^{360}$ Esse procedimento de discovery faculta à parte solicitar à parte adversa em um processo judicial a apresentação compulsória de informações e documentos que podem ser úteis à solução do litígio.

${ }^{361}$ Cf. EUROPA. EUROPEAN COMMISSION. Commision notice on immunity from fines and reduction of fines in cartel cases. OJ 2006/C 298/11, de 08.12.2006.

${ }_{362}^{36}$ MOREIRA, Eduardo Ataide de Souza; PEÑALOZA, Rodrigo. Op. cit.

${ }^{363}$ Cf. EUROPA. EUROPEAN COMMISSION COMPETITION. Authorities in EU Member States which operate a leniency programme.
} 
Europeia, sancionadas com multas pecuniárias de até $10 \%$ do faturamento mundial da empresa. Já na seara penal, o cartel configura crime previsto na seção 188 do Enterprise Act $2002 .^{364}$

Como instrumento de combate a essas condutas antitruste, esse país adotou um Programa de Leniência que oferece àquele que contribuir com as autoridades da Office of Fair Trading (OFT) - órgão responsável pela aplicação das leis concorrenciais e de proteção aos consumidores no Reino Unido - redução de multas pecuniárias e imunidade penal $^{365}$ com relação à prática ilícita delatada.

No tocante à imunidade penal, esta pode ser obtida diretamente pelos funcionários e dirigentes da empresa envolvida no cartel e resultar da celebração de um acordo de leniência entre a própria empresa participante do ilícito e as autoridades concorrenciais britânicas.

A política de leniência implementada prevê três tipos de benefícios:

- Imunidade Tipo A - oferecida ao participante que primeiro se candidatar à leniência, quando ainda não há investigação em curso sobre a prática ilícita delatada.

\footnotetext{
${ }^{364}$ Cf. REINO UNIDO. OFFICE OF FAIR TRADING. Leniency in cartel cases. A guide to the leniency programme for cartels.

${ }^{365}$ De acordo com a legislação do Reino Unido, o crime de cartel é punido da seguinte maneira: "The cartel offence will be triable either in a magistrates' court (summary trial) or before a jury in the Crown Court (trial on indictment). Before the magistrates, a convicted offender may receive a maximum of six-months imprisonment and/or a fine up to the statutory maximum. On conviction on indictment, an offender may receive a maximum of five years' imprisonment and/or an unlimited fine. In England and Wales, and in Northern Ireland, prosecutions will generally be undertaken by the Serious Fraud Office (SFO), although the OFT will also have the power to prosecute. Private prosecutions may be brought only with the consent of the OFT. In Scotland, prosecutions will be brought by the Lord Advocate. 2.7 Where cross-jurisdictional issues arise, the jurisdiction in which a case will be brought will depend on the outcome of discussions between the $O F T$, the SFO and the Lord Advocate's office, and will follow the well-established principles that govern other criminal prosecutions." Tradução livre: "O delito de cartel será julgado em uma corte de magistrados (julgamento sumário) ou diante de um júri na Corte Crown (julgamento por acusação). Diante dos magistrados, um réu condenado pode receber uma pena de até seis meses de prisão e/ou uma multa no máximo legal. Na condenação por acusação, ele pode receber uma pena de até cinco anos de prisão e/ou uma multa ilimitada. Na Inglaterra e no País de Gales e no norte da Irlanda, os processos são, geralmente, conduzidos pelo Serious Fraud Office (SFO), não obstante a OFT também tenha poder de processar. Ações privadas somente podem ser ajuizadas com o consentimento da OFT. Na Escócia, as ações serão ajuizadas pelo Lord Advocate. $2.7 \mathrm{Na}$ hipótese de surgirem questões de competência, a jurisdição na qual o caso será levado dependerá do resultado das discussões entre a OFT, a SFO e o escritório do Lord Advocate e seguirá os princípios estabelecidos que orientam outras ações penais." (REINO UNIDO. OFFICE OF FAIR TRADING. The cartel offence: guidance on the issue of no-action letters for individuals).
} 
- Imunidade (e leniência) Tipo B - oferecida ao participante que primeiro se candidatar à leniência, no entanto, já com uma investigação prévia existente.

- Leniência Tipo $\mathbf{C}$ - oferecida ao participante que, apesar de não ser o primeiro a se qualificar, pode contribuir com informações importantes a respeito da conduta investigada. ${ }^{366}$

Na imunidade do Tipo A, a OFT oferece imunidade total com relação às penas pecuniárias, mas desde que a empresa:

- $\quad$ repasse à OFT todas as informações, documentos e provas disponíveis a respeito da conduta cartelizadora;

- $\quad$ coopere plena e permanentemente durante as investigações;

- $\quad$ cesse a prática ilícita no ato da delação à OFT, exceto se as autoridades determinarem a sua continuidade;

- não tenha coagido outras empresas a praticar a conduta.

Cumpridas essas condições, a OFT concede a imunidade penal para todos os diretores e empregados da empresa, atuais ou já desligados desta, que cooperem com o acordo. $^{367}$

\footnotetext{
${ }^{366} \mathrm{Cf}$. Idem, ibidem.

${ }^{367}$ Cf. "Type A immunity: First to come forward and no pre-existing investigation
}

To encourage companies to come forward, the OFT will grant total immunity from financial penalties for an infringement of Article 101 and/or the Chapter I prohibition to a participant in cartel activity who is the first to come forward where there is no preexisting investigation and the company: (a) provides the OFT with all the information, documents and evidence available to it regarding the cartel activity; (b) maintains continuous and complete co-operation throughout the investigation and any appeals; (c) refrains from further participation in the cartel activity from the time of disclosure of the cartel activity to the OFT (except as may be directed by the OFT); and (d) has not taken steps to coerce another undertaking to take part in the cartel activity ("Type A immunity"). Where the above conditions are fulfilled, the OFT will also grant complete criminal immunity under the cartel offence provisions of the Enterprise Act to all cooperating former and current directors and employees of the applicant." Tradução livre: "Imunidade Tipo A: Primeiro a se apresentar e ausência de investigação preexistente

Para estimular empresas a se apresentarem, a OFT concederá imunidade total das sanções pecuniárias previstas para a infração do Artigo 101 e/ou a proibição do Capítulo I ao participante da prática cartelizadora que primeiro se apresentar sem que haja investigação preexistente e a empresa: (a) fornecer à OFT todas as informações, documentos e provas disponíveis sobre a conduta cartelizadora; (b) manter cooperação contínua e plena enquanto durar a investigação e eventuais recursos; (c) abster-se de qualquer participação em práticas 
Na imunidade Tipo B, o candidato a leniente é o primeiro a se qualificar na OFT, porém não pode ingressar no acordo do Tipo A, pois já há uma investigação em curso sobre a prática que pretende delatar. Ainda assim, levando em conta que o candidato foi o primeiro e pode trazer informações relevantes para a apuração dos fatos, a OFT oferece as mesmas imunidades previstas para o acordo Tipo A, desde que preenchidos os requisitos previstos para a sua obtenção. Mas enquanto a concessão da imunidade no primeiro tipo é obrigatória e, portanto, prevista como um direito do leniente, no Tipo B ela é absolutamente discricionária.

Nos casos em que a OFT decidir por não aplicar a imunidade do tipo B, é permitida ainda a concessão da leniência Tipo B, isto é, uma redução de até 100\% das multas e imunidade criminal para os diretores e empregados da empresa candidata que cooperarem com as investigações. No entanto, não há garantia de imunidade para todos: a OFT pode se recusar a concedê-la para determinados indivíduos. ${ }^{368}$

cartelizadoras a partir da revelação da atividade ilícita à OFT (exceto se o contrário for determinado pela OFT; (d) não coagiu outra empresa a participar na conduta cartelizadora ("Imunidade Tipo A"). No caso de preenchimento das condições acima, a OFT também concederá imunidade criminal completa nos termos das disposições sobre o delito de cartel do Enterprise Act para todos os diretores e funcionários que cooperarem (atuais ou já desligados da empresa)." (HOLMES, Simon; GIRARDET, Philipp. Chapter 40: United Kingdom. In: The International Comparative Legal Guide to: cartels and leniency 2011: a practical crossborder insight into cartels and leniency).

${ }^{368}$ Cf. "Type B immunity: First to come forward but there is a preexisting investigation

Alternatively, if an undertaking is the first to report the cartel conduct (possibly after an OFT inspection) but does not qualify for Type A immunity because there is a pre-existing investigation, it can still qualify for Type $B$ immunity if it fulfils the other conditions of Type A immunity set out above and is still able to 'add significant value' to the OFT's investigation. In return for the company's cooperation and to reward the fact that the company was the first to apply for leniency, the company is granted complete immunity from fines (as under Type A) and complete criminal immunity under the cartel offence provisions of the Enterprise Act to all cooperating former and current directors and employees of the applicant. Whilst Type A immunity is available as of right if the necessary conditions are met, Type B immunity is discretionary. However, the OFT's Guidance states that the grant of Type B immunity (rather than Type B leniency - see below) can be "expected to be the norm rather than the exception.

Type B leniency: First to come forward but there is a preexisting investigation and no immunity is offered Type B leniency refers to the situation where a company is the first company to report the cartel conduct to the OFT (possibly after an OFT inspection) but does not qualify for Type A immunity because there is already a pre-existing investigation and the OFT exercises its discretion not to offer Type B immunity to the applicant. Under Type B leniency the OFT can offer a reduction in fines of up to 100 per cent and individual criminal immunity for the applicant's cooperating former and current directors and employees. There is, however, no automatic criminal immunity for all implicated individuals under Type B leniency and the OFT may refuse to grant criminal immunity to a number of key implicated individuals."

Tradução livre: "Imunidade Tipo B: Primeiro a se apresentar, mas já existe uma investigação prévia.

Alternativamente, se uma empresa é a primeira a reportar uma conduta cartelizadora (possivelmente após uma inspeção da OFT), mas não se qualifica para a imunidade Tipo A porque já existe uma investigação prévia, ela ainda pode se qualificar para imunidade Tipo B se preencher as demais condições da imunidade Tipo A estabelecidas acima e ainda é capaz de 'adicionar valor significante' à investigação da OFT. Em troca da cooperação da empresa e para recompensar o fato de que esta foi a primeira a requerer leniência, a empresa receberá imunidade completa com relação às multas (como no Tipo A) e imunidade criminal 
Na leniência Tipo C, a OFT decide beneficiar mais de um participante em um mesmo caso, tendo em vista as relevantes informações que o candidato pode trazer às autoridades. Assim, este tipo de leniência é direcionado para aqueles que não conseguiram se qualificar em primeiro lugar ou coagiram outras empresas a participar da conduta cartelizadora. Como recompensa pela cooperação dessas empresas, a OFT lhes oferece redução de até $50 \%$ na multa aplicada e a possibilidade de imunidade criminal para os seus funcionários. ${ }^{369}$

Nesse contexto, de rigor mencionar que a imunidade penal é concedida mediante uma carta expedida pela OFT chamada no-action letter (prevista na seção 190 do Enterprise Act 2002), que impede a persecução penal contra determinado indivíduo na

completa nos termos das disposições sobre o delito de cartel do Enterprise Act para todos os diretores e funcionários que cooperarem (atuais ou já desligados da empresa). Enquanto a imunidade Tipo A está disposta como um direito se as condições necessárias forem preenchidas, a Tipo B é discricionária. No entanto, o Guia da OFT estabelece que a concessão da imunidade Tipo B (ao contrário da leniência Tipo B veja a seguir) pode ser 'esperada como regra, não exceção'.

Leniência Tipo B: Primeiro a se apresentar, mas já existe uma investigação prévia e nenhuma imunidade é oferecida

Leniência Tipo B refere-se a uma situação em que uma empresa é a primeira a reportar uma conduta cartelizadora à OFT (possivelmente após uma inspeção da OFT), mas não se qualifica para a imunidade Tipo A porque já existe uma investigação prévia e a OFT utiliza-se de sua discricionariedade para não oferecer a imunidade Tipo B ao candidato. Nos termos da leniência Tipo B, a OFT pode oferecer uma redução nas multas de até $100 \%$ e imunidade criminal individual para diretores e funcionários que cooperarem (atuais ou já desligados da empresa). Não há, porém, imunidade criminal automática para todos os indivíduos envolvidos na leniência Tipo B e a OFT pode recusar-se a conceder imunidade criminal a uma série de indivíduos-chave envolvidos na conduta." (HOLMES, Simon; GIRARDET, Philipp. Chapter 40: United Kingdom. In: The International Comparative Legal Guide to: cartels and leniency 2011: a practical crossborder insight into cartels and leniency).

${ }^{369} \mathrm{Cf}$. "Type C leniency: Not first to come forward but can 'add significant value'

Should the OFT consider that leniency ought to be granted to more than one party in a case, Type Cleniency is in principle available to a company which is not the 'first in' but can still 'add significant value' to the OFT's investigation. Accordingly, it is available to companies which are not the first to apply for leniency and/or which have coerced another undertaking into participating in the reported cartel conduct. In return for the company's cooperation the OFT will grant a reduction of up to 50 per cent of the level of financial penalty imposed under the Competition Act (or the TFEU). The value of any reduction granted will primarily depend on the evidential value a company was able to add to the OFT's investigation compared with the information already in the OFT's possession at the time of the application. Criminal immunity for individual former and current employees of the applicant must be agreed on an individual basis with the OFT under Type Cleniency."

Tradução livre: "Leniência Tipo C: Não é o primeiro a se apresentar, mas pode 'adicionar valor significante'

Na hipótese de a OFT considerar que a leniência deve ser concedida a mais de um participante em um caso, a Tipo C está disponível para aquela empresa que não é a primeira, mas ainda pode adicionar valor significante à investigação da OFT. Portanto, ela está disponível para empresas que não são a primeira a se apresentar para leniência e/ou coagiram outras empresas a participar na prática cartelizadora. Em troca da cooperação da empresa, a OFT concederá redução de até $50 \%$ da sanção pecuniária imposta nos termos do Competition Act (ou o TFEU). O montante de qualquer redução concedida dependerá, principalmente, do valor das provas que a empresa for capaz de adicionar à investigação da OFT comparado com as investigações já em poder da OFT no momento do requerimento. A imunidade criminal para funcionários (atuais ou já desligados da empresa) deve ser acordada individualmente com a OFT nos termos da leniência Tipo C." (HOLMES, Simon; GIRARDET, Philipp. Op. cit.). 
Inglaterra, no País de Gales e Irlanda do Norte. ${ }^{370}$ Esta carta é, entretanto, passível de revogação se o beneficiário não satisfizer uma das condições previstas para a concessão de imunidade ou, ainda, se fornecer, dolosa ou culposamente, informações falsas ou enganosas. $^{371}$

No que tange ao sigilo das informações apresentadas às autoridades britânicas em razão de um acordo de leniência, é assegurada ao delator a garantia de que tais informações não serão utilizadas contra ele em um processo criminal, exceto se houver revogação da no-action letter ou o delator tiver, dolosa ou culposamente, apresentado informações falsas ou enganosas.

Assim como no Programa de Leniência norte-americano, no Reino Unido não basta a observância de todas as exigências legais para a obtenção dos benefícios. Na hipótese de as autoridades britânicas entenderem que já possuem, ou estão em vias de obter, as provas necessárias para iniciar um processo criminal contra o delator, a anistia criminal não será concedida. Igualmente, não haverá imunidade penal no caso de a OFT entender não ser provável a instauração de processo criminal contra o delator. ${ }^{372}$

\footnotetext{
${ }^{370} \mathrm{Na}$ Escócia, a no-action letter não impede a persecução penal, mas a cooperação do leniente é levada em consideração pelo Lord Advocate, órgão competente para iniciar um processo penal em face dos participantes de cartel neste país, que poderá até decidir preliminarmente, quando julgar conveniente, sobre a punibilidade do delator.

${ }^{371} \mathrm{Cf}$. "A no-action letter may be revoked if: the recipient of a letter ceases to satisfy in whole or in part any of the relevant conditions (set out at paragraph 3.3 above), or the recipient of a letter has knowingly or recklessly provided information that is false or misleading in a material particular." Tradução livre: "Uma carta no-action pode ser revogada se o conteúdo dela parar de satisfazer totalmente ou em parte qualquer uma das condições relevantes (dispostas no parágrafo 3.3 acima), ou o seu conteúdo fornecer, dolosa ou culposamente, informações falsas ou enganosas sobre questão importante." (REINO UNIDO. OFFICE OF FAIR TRADING. The cartel offence: guidance on the issue of no-action letters for individuals).

${ }^{372} \mathrm{Cf}$. "Where the OFT believes that it already has, or is in the course of gathering, sufficient information to bring a successful prosecution of an individual, it will not issue a no-action letter to that individual. (...) In cases where the OFT concludes that, on the basis of the information that has been given, the applicant is not at risk of criminal prosecution for the cartel offence, it will not issue a no-action letter for this reason and will confirm this in writing." Tradução livre: "No caso de a OFT acreditar que já possui ou está em vias de coletar informações suficientes para um processo bem-sucedido contra um indivíduo, ela não lhe emitirá a carta no-action. (...) Nos casos em que a OFT concluir que, baseada nas informações que lhe foram fornecidas, o candidato não corre o risco de ser processado criminalmente pela prática do delito de cartel, ela não emitirá a carta no-action por esta razão e confirmará isto por escrito." (REINO UNIDO. OFFICE OF FAIR TRADING. The cartel offence: guidance on the issue of no-action letters for individuals).
} 


\subsubsection{França}

A França, por sua vez, traz normas mais flexíveis com relação ao programa comunitário europeu, aplicáveis a cartéis e a outros tipos de acordos entre concorrentes. ${ }^{373}$ As práticas anticompetitivas são proibidas pelo artigo L. 420-1 do Código Comercial francês (Code de Commerce) ( $^{374}$ e a sua infração pode gerar consequências nas esferas civil, administrativa e criminal. ${ }^{375}$

O Programa de Leniência francês, utilizado pela Autoritè de la concurrence e pela Direction générale de la concurrence, de la consommation et de la répression des fraudes - responsáveis pela implementação de medidas de combate a condutas anticompetitivas -, foi criado em 2001. Diferentemente de muitos outros países em que a implementação do Programa de Leniência ocorreu por meio de um ato administrativo das autoridades responsáveis pela defesa da concorrência, na França, o acordo de leniência está previsto nos artigos L. 464-2 IV e R. 464-5 do Código Comercial francês. Mas sob o aspecto prático, é regulamentado pela publicação emitida pela própria autoridade concorrencial em 2 de março de $2009 .^{376}$

\footnotetext{
${ }^{373}$ Global competition review. France refines leniency, 26.04.06. Apud RODAS, João Grandino. Acordos de leniência em direito concorrencial: práticas e recomendações. P. 26.

${ }^{374} \mathrm{O}$ artigo L. 420-1 do Código Comercial francês proíbe práticas concertadas, acordos e alianças, expressos ou tácitos, entre empresas concorrentes que tenham por objeto ou possam resultar em prejuízo à concorrência de mercado, sobretudo aqueles que visam a criação de barreiras à entrada de novos agentes econômicos no mercado, a fixação de preços, a coordenação do volume de produção, dos investimentos e do desenvolvimento tecnológico e a divisão de mercados.

375 Cf. "The Competition Authority may impose fines on individuals engaged in economic activities amounting to a maximum of $€ 3$ million for breach of Article L. 420-1 of the Code. This provision is designed to cover sole traders who engage in cartel-type behaviour. In addition, according to Article L. 420-6 of the Code, individuals may be subject to criminal penalties amounting to fines of up to €75,000 and terms of imprisonment of up to four years where they have fraudulently taken a personal and decisive action in the conception, organisation and/or implementation of the anticompetitive practices. These penalties are not imposed by the Competition Authority itself, but by criminal courts following referral by the Competition Authority to the Public Prosecutor (Procureur de la Republique) for further investigation." Tradução livre: "A Autoritè de la concurrence pode impor multas para indivíduos envolvidos em atividades econômicas de, no máximo, €3 milhões por violação ao Artigo L. 420-1 do Código. Essa disposição é projetada para cobrir comerciantes individuais que se envolveram em conduta cartelizadora. Ademais, nos termos do Artigo L. 420-6 do Código, os indivíduos estão sujeitos a sanções criminais pecuniárias no valor de até €75,000 e pena de prisão de até quatro anos nos casos em que eles tomaram atitudes fraudulentas decisivas e pessoais na concepção, organização e/ou implementação das práticas anticoncorrenciais. Essas penalidades não são impostas pela Autoritè de la concurrence, mas pelas cortes criminais em atendimento à indicação feita pela Autoritè de la concurrence ao promotor (Procureur de la Republique) para prosseguir com as investigações." (COHEN, Delphine; ASSADIF-TARDIF, Natasha. Chapter 15. France. In: The International Comparative Legal Guide to: Cartels and Leniency 2011: a practical cross-border insight into cartels and leniency).

${ }^{376}$ FRANÇA. AUTORITÈ DE LA CONCURRENCE. Procedural notice of 02 march 2009 relating to the french leniency programme.
} 
De acordo com a política de leniência francesa, o candidato pode obter a redução parcial ou a anistia total de sanções pecuniárias em troca de informações e de sua plena cooperação com investigações sobre uma determinada prática anticompetitiva.

Para a obtenção da imunidade total das multas, a empresa candidata deve ser a primeira a se qualificar e a prática anticompetitiva que se pretende delatar deve ser inédita para a Autoritè de la concurrence. As autoridades antitruste francesas exigem, ainda, que o candidato a leniente forneça as seguintes informações:

- $\quad$ Nomes e endereços dos outros participantes da conduta ilícita.

- Descrição detalhada dos mercados envolvidos e do ajuste levado a efeito.

- Dados sobre outras propostas de leniência sobre a mesma conduta que se apresentou, ou que se pretende apresentar, para outras autoridades.

- Todas as provas que possua no momento da qualificação. ${ }^{377}$

Mesmo que a Autoritè de la concurrence já possua alguma informação sobre a prática que será delatada, a imunidade total das sanções pecuniárias poderá ser concedida, desde que preenchidas as seguintes condições:

- O candidato deve ser o primeiro a entregar provas que, sob o ponto de vista das autoridades, sejam suficientes para comprovar a existência da conduta antitruste.

- No momento da qualificação, as autoridades não tenham provas suficientes para a comprovação da infração.

- Nenhuma outra empresa tenha obtido a proposta condicional de imunidade total. ${ }^{378}$

377 COHEN, Delphine; ASSADIF-TARDIF, Natasha. Op. cit.
378 Cf. "Full immunity from fines: In cases where the Competition Authority has no information about the
alleged anticompetitive agreement or practice, the Competition Authority can grant total immunity from fines
to any firm that is the first to submit information enabling the Competition Authority to carry out
investigations and establish the existence of the anticompetitive agreement or practice. In practice, in
addition to its name and address, the applicant must, at least, provide the following information: the names
and addresses of the other alleged members of the anticompetitive agreement or practice; a detailed
description of the markets concerned and the anticompetitive arrangement; information about any leniency
application relating to the alleged anticompetitive agreement or practice which it has submitted or intends to
submit to other competition authorities; and any evidence in its possession at the time of its application. If
the Competition Authority already has certain information on the alleged anticompetitive agreement or 
Já para aqueles que não conseguirem se qualificar para obtenção de imunidade total há a possibilidade de se beneficiarem com a imunidade parcial, ou seja, uma redução das multas de até 50\%. Para tanto, o candidato deve fornecer provas de significante valor para a Autoritè de la concurrence, consideradas aquelas já em poder das autoridades. Nestes casos, a fim de determinar o nível de redução das multas, as autoridades consideram: a ordem cronológica de qualificação para o programa, o momento em que a prova foi apresentada e a extensão do poder das provas entregues pelo candidato para comprovar o envolvimento dos membros do cartel sob apuração. ${ }^{379}$

Ademais, para a aferição da redução da multa também influenciará se o candidato a leniente providenciar provas substanciais que permitam à Autoritè de la concurrence comprovar fatos adicionais diretamente ligados com o montante da multa a ser aplicada aos demais participantes da prática anticompetitiva.

practice, full immunity can be granted if the three following conditions are met: the applicant is the first to submit evidence which, in the Competition Authority's view, is sufficient to establish the existence of the anticompetitive agreement or practice; at the time of the application, the Competition Authority did not have sufficient evidence to establish the existence of an infringement, and no other firm has obtained a conditional opinion granting full immunity with respect to its participation in the alleged anticompetitive agreement or practice." Tradução livre: "Imunidade total das multas: Nos casos em que a Autoritè de la concurrence não possui informações sobre a prática ou o ajuste anticoncorrencial alegado, ela poderá conceder imunidade total das multas para qualquer empresa que seja a primeira a apresentar informações que a permitam iniciar investigações e constatar a existência da prática ou do ajuste anticoncorrencial. Na prática, além de seu nome e endereço, o candidato deve, no mínimo, fornecer as seguintes informações: nomes e endereços dos demais membros mencionados envolvidos na prática ou ajuste anticoncorrencial; uma descrição detalhada dos mercados envolvidos e do ajuste anticoncorrencial; informações sobre qualquer outro requerimento de leniência referente à prática ou ajuste anticoncorrencial que se submeteu ou se pretende submeter a outras autoridades concorrenciais; quaisquer provas em seu poder no momento do requerimento. Se a Autoritè de la concurrence já tiver alguma informação sobre a prática ou ajuste anticoncorrencial alegado, a imunidade total pode ser concedida se preenchidas as três condições seguintes: o candidato for o primeiro a apresentar provas que, na visão da Autoritè de la concurrence, são suficientes para constatar a existência do ajuste ou da prática anticoncorrencial; no momento do requerimento, a Autoritè de la concurrence não tem provas suficientes para constatar a existência de uma infração e nenhuma outra empresa obteve um parecer condicional pela concessão de imunidade total com relação à sua participação na prática ou ajuste anticoncorrencial alegado." (COHEN, Delphine e ASSADIF-TARDIF, Natasha. Idem, ibidem, grifos no original).

${ }^{379}$ Cf. “[...] (ii) Partial immunity from fines: Undertakings that do not meet the basic conditions for full immunity can benefit from reduced fines by providing the Competition Authority with evidence of the alleged breach. Such evidence must represent significant added value taking into account the evidence already in the Competition Authority's possession. In order to determine the level of reductions in fines from which a firm may benefit, the Competition Authority will take into consideration the chronological order in which leniency applications were filed, the time when the evidence was submitted, as well as the extent to which the information submitted by the firm brought significant added value to the case against the cartel members." Tradução livre: “[...] (ii) Imunidade parcial de multas: Empresas que não preenchem as condições básicas para imunidade plena podem se beneficiar com redução de multas mediante o fornecimento de provas à Autoritè de la concurrence acerca da infração. Essas provas devem representar valor significativo, considerando as provas que a Autoritè de la concurrence já tem em seu poder. A fim de determinar o nível de redução das multas que pode beneficiar a empresa, a Autoritè de la concurrence levará em consideração a ordem cronológica de arquivamento dos requerimentos de leniência, o momento em que as provas foram entregues, assim como o valor significativo trazido ao processo instaurado em face dos membros do cartel pelas informações.” (COHEN, Delphine e ASSADIF-TARDIF, Natasha. Idem, ibidem, grifos no original). 
No que concerne aos reflexos penais do Programa de Leniência francês, insta registrar que não há previsão alguma acerca da imunidade penal, de modo que o acordo não impede a instauração de investigação criminal ou ação penal em face de empregados e diretores da empresa beneficiada. Não obstante, a Autoritè de la concurrence, em sua publicação de 02 de março de 2009, reconheceu que o acordo de leniência é uma das razões legítimas para que o processo instaurado não seja encaminhado ao órgão acusatório e para que os funcionários e dirigentes da empresa leniente não sejam responsabilizados criminalmente pela prática do ilícito. ${ }^{380}$

\subsubsection{Grécia}

O programa grego é mais restrito que o comunitário. Empresas que tenham participado em mais de um cartel não têm permissão para se beneficiar do programa. Do mesmo modo, não podem se candidatar ao programa as empresas que tenham chamado, e não coagido, outras a participar da conduta anticoncorrencial. ${ }^{381}$

Antes de prosseguir com a análise do Programa de Leniência, cumpre registrar que na Grécia, o artigo $1^{\circ}$ da Lei $n^{\circ} 703 / 1977$ proíbe a prática de cartel e de tantas outras formas de ajustes entre concorrentes que tenham como finalidade ou consequência a restrição ou manipulação da concorrência. Perante essa legislação, tais práticas configuram apenas infrações civis e administrativas.

\footnotetext{
${ }^{380}$ Cf. "Pursuant to paragraph 2 of article L. 462-6 of the code de commerce, the Autorite may pass the case file on to the French State Prosecutor's office if, in its view, facts of the case are such as to justify the application of article L. 420-6 of the said code. Article L. 420-6 only applies if three cumulative conditions are met: the individual must have fraudulently played a personal and decisive role in the creation, organisation or implementation of the practices referred to in article L. 420-1. The Autorité considers that leniency is one of the legitimate reasons which justifies not to pass on to the State Prosecutor a case file in which individuals, belonging to the undertaking which has been granted leniency, would be liable to such proceedings". Tradução livre: "De acordo com o parágrafo 2 do artigo L. 462-6 do code de commerce, a Autorité pode passar o caso para o escritório do promotor francês se, sob o seu ponto de vista, os fatos justificarem a aplicação do L. 420-6 do mesmo diploma. Somente se aplica o artigo L. 420-6 se preenchidas três condições cumulativamente: o indivíduo exercer papel pessoal e decisivo, de maneira fraudulenta, na criação, organização ou implementação das práticas dispostas no artigo L. 420-1. A Autorité considera que a leniência é uma das razões legítimas que justifica a não condução ao promotor de um caso no qual indivíduos, vinculados à empresa que recebeu a leniência, estariam sujeitos à instauração de processos." (FRANÇA. AUTORITÈ DE LA CONCURRENCE. Procedural notice relating to the french leniency programme issued on march 2nd, 2009).

${ }^{381}$ RODAS, João Grandino. Acordos de leniência em direito concorrencial: práticas e recomendações. P. 26.
} 
Após uma recente alteração legislativa, a lei concorrencial grega passou a prever penas privativas de liberdade, ao lado de sanções pecuniárias, para indivíduos que tenham se envolvido no gerenciamento de cartéis. ${ }^{382}$ Ainda assim, o Programa de Leniência grego não prevê imunidade penal, apenas anistia ou reduz penas pecuniárias, como se verá adiante.

A autoridade antitruste grega, Hellenic Competition Commission (HCC), oferece imunidade total se:

- a empresa for a primeira a entregar provas suficientes para o início de uma investigação sobre uma infração ao artigo $1^{\circ}, \S 1^{\circ}$ da Lei $n^{\circ} 703 / 1977$ ou ao artigo 81, $\S 1^{\circ}$, do Tratado da União Europeia ou provas que permitam à HCC descobrir uma séria infração ao artigo $1^{\circ}, \S 1^{\circ}$ da Lei $n^{\circ} 703 / 1977 ;^{383}$

- $\quad$ a HCC não possuir provas suficientes para tanto;

- $\quad$ nenhuma empresa tiver sido beneficiada com a imunidade. ${ }^{384}$

Além disso, como na maioria dos programas de leniência europeus, para a concessão do benefício, é necessário o preenchimento dos seguintes requisitos:

${ }^{382}$ Cf. DRAKAKAK, Stamatis. Chapter 17: Greece. In: The international comparative legal guide to: cartels and leniency 2011: a practical cross-broder insight into cartels and leniency.

383 No original: "1. The Hellenic Competition Commission grants an undertaking immunity from any threatened fine which would otherwise have been imposed if: a) the undertaking is the first to submit evidence which is sufficient for the initiation of the investigation procedure concerning a serious infringement of article 1 par. 1 of law 703/1977 or also of article 81 par. 1 EC, or b) the undertaking is the first to submit evidence which enable the Hellenic Competition Commission to find a serious infringement of article 1 par. 1 of law 703/1977 or also of article 81 par. 1 EC." (GRÉCIA. HELLENIC COMPETITION COMMISSION. Decision $\mathbf{n}^{\circ} \mathbf{2 9 9 / v / 2 0 0 6}$ of the plenary of the hellenic competition commission).

${ }^{384}$ No original: "[...] 2. Immunity from fines pursuant to paragraph 1 (a) will only be granted on the condition that the services of the Hellenic Competition Commission did not have, at the time of the submission, sufficient evidence for the initiation of the investigation procedure in connection with the alleged infringement. 3. Immunity pursuant to paragraph 1 (b) will only be granted on the cumulative conditions that the services of the Hellenic Competition Commission did not have, at the time of the submission, sufficient evidence to find an infringement of article 1 par. 1 of law 703/1977 or also of article 81 par. 1 EC and that no undertaking had been granted conditional immunity from fines under paragraph $1($ a) in connection with the alleged infringement." Tradução livre: “[...] 2. A imunidade das multas, de acordo com o parágrafo 1 (a), somente será concedida se a Hellenic Competition Commission não tiver, no momento da submissão, provas suficientes para o início de uma investigação com relação à infração alegada. 3. A imunidade de acordo com o parágrafo 1 (b) somente será concedida se as seguintes condições forem cumulativamente cumpridas: a Hellenic Competition Commission não tenha, no momento da submissão, provas suficientes para descobrir uma infração ao artigo 1, par. 1 da Lei no 703/1977 ou do artigo 81 par. 1 EC e nenhuma outra empresa tenha sido beneficiada com a imunidade condicional de multas nos termos do parágrafo 1 (a) com relação à infração alegada." (Idem, ibidem). 
“(a) the undertaking must cooperate fully, actively and on a continuous basis throughout the procedure and expeditiously provide all information and evidence that is available to it or comes into its possession at a later stage relating to the suspected infringement. In particular, it remains at the Directorate General of Competition's ['DGC'] and at the Hellenic Competition Commission's disposal to answer swiftly any question or request that may contribute to the establishment of the facts concerned; (b) the undertaking must end its involvement in the suspected infringement no later than the time at which it submits evidence under paragraphs 1 (a) or 1 (b); (c) the undertaking must not have urged other undertakings to participate in the infringement; (d) the undertaking must keep confidential vis-à-vis any third party the fact that it has submitted a leniency application until the conclusion of the Statement of Objections for the case by the DGC; (e) the undertaking must not have participated in the past in a prohibited collusive practice for which a decision by a National Competition Authority or the European Commission has been issued.",385

O candidato que não conseguir atingir as condições previstas para a obtenção de imunidade penal pode se beneficiar de uma redução de multa, desde que entregue às autoridades provas significantes - considerando aquelas já em poder da HCC - sobre a prática sob investigação e cessar seu envolvimento na conduta ilegal. O nível de redução da sanção pecuniária será de: $30 \%$ a $50 \%$ se a empresa for a primeira a se qualificar, $20 \%$ a $30 \%$ se for a segunda, até $30 \%$ para todas as empresas subsequentes, somada a esse critério cronológico a importância da cooperação do candidato. ${ }^{386}$

385 Tradução livre: “(a) a empresa deve cooperar plena, ativamente, de maneira contínua durante o
procedimento e rapidamente fornecer todas as informações e provas que possua ou que venha a possuir
posteriormente com relação à infração suspeita. Na realidade, permanece à disposição do Directorate
General of Competition [DGC] e da Hellenic Competition Commission para responder prontamente
quaisquer questionamentos ou requerimentos que possam contribuir com a comprovação dos fatos em
questão; (b) a empresa deve cessar o seu envolvimento na conduta suspeita assim que fornecer provas nos
termos dos parágrafos 1 (a) ou 1 (b); (c) a empresa não tenha estimulado outras a participar da infração; (d) a
empresa deve manter sigilo vis-à-vis a terceiro participante sobre sua qualificação no programa até a
conclusão da Declaração de Objeções do caso pelo DGC; e (e) a empresa não tenha, no passado, participado
de outras práticas colusivas apuradas por uma autoridade antitruste nacional ou da Comissão Europeia."
(Idem, ibidem).
386 No original: "The reduction is determined on the basis of the fines which would otherwise have been
imposed.
For the: - first undertaking to meet paragraph 15: a reduction of $30-50 \%$, second undertaking to meet
paragraph $15:$ a reduction of $20-30 \%$, - subsequent undertakings that meet paragraph 15: a reduction of up
to $20 \%$. In order to determine the level of fine reduction within the above bands, the Hellenic Competition
Commission will take into account the time at which the evidence fulfilling the condition in paragraph 15
was submitted and the extent to which the said evidence represents added value. The Hellenic Competition 


\subsubsection{Canadá}

Além de países europeus, outros já implementaram programas semelhantes, como o Canadá e a Austrália, todos constantemente empenhados em desenvolver e aperfeiçoar suas diretrizes de combate aos cartéis.

No Canadá, o Programa de Leniência foi introduzido no país pela Competition Bureau, órgão responsável pela defesa da concorrência e pela aplicação dos dispositivos cíveis e criminais do Competition Act. Em particular na esfera criminal, este normativo destina-se a reprimir os cartéis - notadamente aqueles que visam fixação de preços, dominação de mercado e restrições à entrada e saída - considerados no país ilícitos concorrenciais per se. Outras formas de práticas anticoncorrenciais estão previstas no Competition Act, mas apenas como infrações cíveis.

Consoante o Competition Act, os agentes econômicos que cometerem estes delitos estão sujeitos a penas restritivas de liberdade de até 14 anos de prisão e/ou sanção pecuniária de C\$ 25.000.000,00 (vinte e cinco milhões de dólares canadenses). Já no âmbito civil, os responsáveis sujeitam-se ao pagamento de uma indenização correspondente aos prejuízos causados. ${ }^{387}$

Na Competition Bureau, o responsável por conduzir procedimentos cíveis e criminais é o Commissioner of Competition, nos termos previstos no Competition Act. A ele cumpre, ainda, recomendar ao Attorney General, mediante comunicação ao Director of Public Prosecutions (DPP), a instauração de ações penais. ${ }^{388}$

Commission may also take into account the extent and consistency of the cooperation provided by the undertaking following the date of submission of the evidence." Tradução livre: "A redução é determinada com base nas multas que seriam impostas. Para: - a primeira empresa a cumprir o parágrafo 15: uma redução de 30-50\%, - a segunda empresa a cumprir o parágrafo 15: uma redução de 20-30\%, - empresas subsequentes a cumprirem o parágrafo 15: uma redução de até $20 \%$. A fim de determinar o nível da redução da multa nas faixas acima, a Hellenic Competition Commission levará em consideração o momento em que as provas foram apresentadas para preencher a condição disposta no parágrafo 15 e a extensão do valor da prova. A Hellenic Competition Commission também pode levar em consideração a extensão e a consistência da cooperação prestada pela empresa após a data de apresentação das provas.” (Idem, ibidem).

${ }^{387}$ Cf. RUSSELL, Robert; PACIOCCO, Mark. Chapter 9. Canada. In: The international comparative legal guide to: cartels and leniency 2011: a practical cross-broder insight into cartels and leniency.

388 Cf. RUSSELL, Robert; PACIOCCO, Mark. Idem, ibidem. Sobre o órgão acusatório canadense, cf. "Criminal prosecutions under the Act are the responsibility of the PPSC, and the Director of Public Prosecutions ("DPP") has the sole authority to grant leniency to a party implicated in an offence under the Act". Tradução livre: "As persecuções criminais referentes ao Act são de responsabilidade do PPSC [Public Prosecution Service of Canada], e o Director of Public Prosecutions ("DPP”) tem a autoridade 
Não obstante, apenas o DPP possui poderes para iniciar um processo penal, antes mesmo de qualquer tribunal canadense, ou conceder imunidade total para um agente econômico envolvido em práticas anticoncorrenciais, de acordo com a política disposta na Federal Prosecution Service Deskbook. ${ }^{389}$

Feitos esses esclarecimentos iniciais, cumpre revelar que o Programa de Leniência canadense oferece imunidade ao agente econômico - empresa ou pessoa física - envolvido em conduta cartelizadora que colaborar com a autoridade antitruste, fornecendo informações e provas a respeito de determinado ilícito concorrencial. A anistia, porém, restringe-se ao âmbito criminal, permanecendo o leniente sujeito às sanções cíveis.

A política adotada prevê, ainda, que a Competition Bureau somente recomendará imunidade criminal ao DPP se a empresa ou pessoa física for a primeira a se candidatar ao programa. Ao levar em consideração a sugestão da autoridade antitruste, o DPP celebrará um acordo denominado Individual Immunity Agreement (ou Corporate Immunity Agreement, se a parte celebrante for pessoa jurídica) contendo a seguinte cláusula:

\section{“[...]}

4. Immunity [Corporate Immunity]: Having considered the recommendation of the Commissioner and, after an independent review pursuant to the policy of the DPP as set out in Part VII of the Federal Prosecution Service Deskbook, conditional upon:

a. the veracity of the representations contained in paragraph 2 above; and

b. the disclosure and cooperation of [ INDIVIDUAL X ] [X LTD] as required pursuant to this agreement;

exclusiva para conceder leniência para a parte envolvida no delito previsto no Act." (CANADA. COMPETITION BUREAU. Leniency program bulletin).

${ }^{389}$ Sobre a política adotada, cf. "This policy is based on a recognition that it is sometimes in the public interest to provide immunity from prosecution to persons who are willing to give material evidence concerning the commission of an offence. Immunity from prosecution should be the exception rather than the norm; it is only provided where the information or co-operation is of such value that it is clearly in the public interest not to hold a person accountable for criminal activity." Tradução livre: "Esta política é fundamentada no reconhecimento de que, às vezes, é de interesse público oferecer imunidade a pessoas que desejam fornecer provas materiais referentes ao cometimento de um delito. A imunidade deve ser a exceção e não a regra; ela somente pode ser oferecida naquelas hipóteses em que a informação ou a cooperação é de tal valor que é evidente o interesse público em não responsabilizar a pessoa pela atividade criminal." (CANADA. PUBLIC PROSECUTION SERVICE OF CANADA. Federal prosecution service deskbook). 
the DPP grants [ INDIVIDUAL X ] [X LTD] immunity from prosecution under

the Act in respect of the anticompetitive conduct." 390

Como se vê, não basta a mera recomendação da Competition Bureau pela anistia penal. Somente após uma análise imparcial pelo DPP, o candidato ao programa poderá estar seguro de sua imunidade total na esfera penal concedida em troca das informações e provas que forneceu às autoridades.

Notadamente, em sendo a primeira colocada uma pessoa jurídica, a Competition Bureau formulará uma recomendação no sentido de que não seja instaurada investigação ou ação penal em face de seus diretores, executivos e funcionários, desde que estes cooperem com o órgão antitruste. A rigor, essa regra é válida mesmo para os que já foram desligados da empresa. A recomendação, contudo, será encaminhada somente após uma análise criteriosa realizada caso a caso pela Competition Bureau. ${ }^{391}$

Dessa maneira, a autoridade concorrencial canadense recomendará imunidade criminal ao DPP com relação à pessoa física que primeiro se candidatar ao programa, mesmo que individualmente e desvinculada de qualquer empresa. ${ }^{392}$

${ }^{390}$ Tradução livre: “[...] 4. Imunidade [Imunidade Corporativa]: Considerando a recomendação do Comissionário e, após uma revisão independente em consonância com a política do DPP, tal como previsto na Parte VII do Federal Prosecution Service Deskbook [sobre acordos de imunidade], condicionando a: a. veracidade das informações contidas no parágrafo 2 acima; e b. a revelação e cooperação do [INDIVÍDUO $\mathrm{X}$ [ [X LTDA.], como requerido nos termos deste acordo, o DPP oferecerá a [INDIVÍDUO X] [X LTDA.] imunidade em processá-lo de acordo com o Act no que se refere à conduta anticompetitiva." (CANADÁ. COMPETITION BUREAU. Individual immunity agreement. e Corporate immunity agreement).

${ }^{391} \mathrm{Cf}$. "At the request of the first-in leniency applicant that is a business organization, the Bureau will recommend that no separate charges be laid against the applicant's current directors, officers or employees, provided that such individuals cooperate with the Bureau's investigation in a full, frank, timely and truthful fashion. Agents and former directors, officers and employees implicated in the offence will also typically qualify for leniency provided that they offer to cooperate with the Bureau's investigation and any subsequent prosecution. The Bureau will make a determination regarding agents and former directors, officers, and employees on a case-by-case basis, for example, depending on the current employment status of such individuals (i.e., if they are currently employed by another party to the offence)." Tradução livre: "No requerimento do primeiro candidato à leniência - que é uma empresa -, a Bureau recomendará que não sejam oferecidas acusações separadas em face de seus diretores, executivos ou funcionários, atuais ou já desligados da empresa, desde que cada um deles coopere com a investigação da Bureau de modo pleno, franco, oportuno e verdadeiro. Agentes e ex-diretores, executivos e funcionários, envolvidos na infração também serão qualificados para a leniência desde que se ofereçam para cooperar com a investigação da Bureau e com qualquer outro procedimento posterior. A Bureau fará uma determinação com relação a agentes e exdiretores, executivos e funcionários em uma análise casuística, por exemplo, dependendo da situação de emprego atual desses indivíduos (isto é, se eles estiverem empregados por outro participante da conduta ilícita)." (CANADA. COMPETITION BUREAU. Leniency program bulletin).

${ }^{392} \mathrm{Cf}$. "Where the first leniency applicant is an individual applying independently (i.e., implicating his or her current or former employer), leniency will be accorded in the same manner as if the individual were covered 
Em paralelo a essa imunidade total, outro benefício, consistente na redução de sanções pecuniárias, é previsto no Programa de Leniência canadense, mormente destinado para aqueles agentes econômicos (pessoas físicas ou jurídicas) que se candidatarem posteriormente. Nestes casos, a Competition Bureau recomendará a leniência ao Public Prosecution Service of Canada quando o candidato:

- $\quad$ cessar a sua participação no cartel;

- concordar em cooperar plenamente, e sob suas expensas, com as investigações e ações penais instauradas contra os demais participantes do cartel;

- confessar sua participação no ilícito. ${ }^{393}$

De rigor ressaltar que, na hipótese de a Competition Bureau já ter encaminhado os resultados de sua investigação ao Public Prosecution Service of Canada, "[...] the Leniency Program will no longer be available to an individual or business organization seeking to resolve criminal liability under the Act in regards to that investigation." 394

No que tange ao escalonamento da redução das sanções pecuniárias, o seguinte critério será adotado: $50 \%$ para o primeiro candidato, $30 \%$ para o segundo e, para os demais, a diminuição dependerá do momento em que cada candidato procurou as autoridades antitruste canadenses com relação ao segundo leniente. Vale destacar que estes

by an employer's leniency application. That is, if the individual meets the eligibility requirements of the Leniency Program and provides full, frank, timely and truthful cooperation, the Bureau will recommend that the individual not be criminally charged". Tradução livre: "Na hipótese de o primeiro candidato a leniente ser um indivíduo apresentando-se independentemente (ou seja, implicando seu empregador atual ou antigo), a leniência será concedida da mesma maneira que se o indivíduo estiver abrangido por um requerimento de acordo de leniência de um empregador. Isto significa que, se ele preencher os requisitos de elegibilidade do Programa de Leniência e oferecer cooperação plena, franca, oportuna e verdadeira, a Bureau recomendará que o indivíduo não seja acusado." (CANADA. COMPETITION BUREAU. Lenience program bulletin.

${ }^{393} \mathrm{Cf}$. "The Bureau will make a recommendation for leniency in sentencing to the PPSC when the individual or business organization: (a) has terminated its participation in the cartel; (b) agrees to cooperate fully and in a timely manner, at its own expense, with the Bureau's investigation and any subsequent prosecution of the other cartel participants by the PPSC; and,(c) agrees to plead guilty." (CANADA. COMPETITION BUREAU. Lenience program bulletin).

394 Tradução livre: "O Programa de Leniência não estará mais disponível para um indivíduo ou uma empresa em busca de solução para a sua responsabilização criminal nos termos do Act no que se refere a esta investigação.” (CANADA. COMPETITION BUREAU. Lenience program bulletin). 
últimos nunca poderão receber uma diminuição em suas multas maior do que aquela concedida aos lenientes anteriores. ${ }^{395}$

\author{
Assim como a imunidade penal total é concedida mediante um Immunity \\ Agreement, a redução das multas será registrada em um acordo denominado Plea \\ Agreement.
}

Insta relembrar que, no que concerne à possibilidade de acusação dos candidatos posteriormente admitidos no Programa de Leniência,

\begin{abstract}
"[...] the Bureau will consider, on a case-by-case basis, whether or not to recommend that a current or former director, officer, employee or agent be charged, considering a number of factors, including: the individual's role and extent of involvement in the offence (e.g., as the cartel instigator, leader or coordinator, or if they have used coercion, or otherwise monitored or encouraged compliance with the illegal arrangement from other participants); the degree to which the individual benefited from the offence; whether the
\end{abstract}

\footnotetext{
${ }^{395}$ Sobre esse criterio, cf.: "The first leniency applicant is eligible for a reduction of 50 percent of the fine that would otherwise have been recommended, provided that the applicant meets the requirements of the Leniency Program, including providing full, frank, timely and truthful cooperation.

14. When an applicant is not the first to come forward under the Leniency Program, a recommendation for a reduction in sentence may nonetheless be available. The second leniency applicant is eligible for a reduction of 30 percent of the fine that would have otherwise been recommended by the Bureau to the PPSC. The 30 percent reduction is premised on the leniency applicant meeting all of the conditions of the Leniency Program to the satisfaction of the Bureau.

15. Subsequent leniency applicants may benefit from reductions to the fine that would have otherwise been recommended, provided that such applicants meet and continue to meet all the conditions of the Leniency Program. The actual amount of the reduction that a subsequent applicant is eligible to receive will depend on when the applicant sought leniency compared to the second-in applicant and the timeliness of its cooperation. As a rule, later leniency applicants will not be eligible for a greater leniency discount than earlier applicants." Tradução livre: "O primeiro candidato à leniência é elegível para a redução de 50\% da multa que seria recomendada, desde que preencha os requisitos do Programa de Leniência, incluindo a cooperação plena, franca, oportuna e verdadeira.

14. Mesmo quando um candidato não for o primeiro a se apresentar ao Programa de Leniência, uma recomendação para redução da multa na sentença pode ser feita. O segundo candidato à leniência é elegível para uma redução de 30\% da multa que seria recomendada pela Bureau ao PPSC. Essa redução de $30 \%$ é prevista desde que o candidato a leniente preencha satisfatoriamente todas as condições do Programa de Leniência da Bureau. 15. Os demais candidatos à leniência podem se beneficiar de reduções de multas que seriam recomendadas, desde que preencham e continuem preenchendo todas as condições do Programa de Leniência. O montante real da redução que os candidatos subsequentes podem receber dependerá do momento em que o requerente procurar a leniência em comparação ao segundo candidato à leniência e de sua oportuna cooperação. Como regra, candidatos posteriores à leniência não serão elegíveis para um desconto de leniência maior que os candidatos anteriores." (CANADA. COMPETITION BUREAU. Lenience program bulletin).
} 
individual is a recidivist or has a criminal record; and any other relevant aggravating or mitigating factors." 396

Entretanto, a Competition Bureau prevê que diretores, executivos, funcionários e agentes colaboradores submetidos a um processo penal "[...] may be eligible to be evaluated by the Bureau as to whether they meet the conditions necessary to receive a lenient treatment recommendation from the Bureau. „397

É fundamental registrar que a Competition Bureau compromete-se a não usar contra o candidato a leniente as informações e provas por ele apresentadas, a não ser que a parte não cumpra as exigências previstas no acordo celebrado. A propósito, se a autoridade antitruste canadense tomar conhecimento que o candidato não cumpriu os termos do acordo (Immunity Agreement ou Plea Agreement), ela poderá recomendar ao DPP que revogue a imunidade concedida. ${ }^{398}$ Inclusive essa faculdade de revogar a imunidade penal é conferida ao DPP de ofício.

\footnotetext{
${ }^{396}$ Tradução livre: "[...] a Bureau considerará, em uma análise casuística, se recomendará ou não a acusação de um diretor, executivo, funcionário ou agente (atual ou já desligado da empresa), considerando uma série de fatores, incluindo: o papel do indivíduo e a extensão de seu envolvimento na infração (por exemplo, como um instigador do cartel, líder ou coordenador, ou se eles se utilizaram de coerção ou, ao contrário, foram monitorados ou estimulados a aderir ao ajuste ilegal de outros participantes); o grau de benefício que o indivíduo teve com a infração; se ele for reincidente ou tiver algum registro criminal e qualquer outro fator agravante ou atenuante." (CANADA. COMPETITION BUREAU. Leniency program. FAQs).

${ }^{397}$ Tradução livre: "[...] podem ser elegíveis para serem avaliados pela Bureau se eles cumprirem as condições necessárias para receber uma recomendação de tratamento leniente pela Bureau." (CANADA. COMPETITION BUREAU. Lenience program bulletin).

${ }^{398}$ Com relação ao programa de leniência, cf.: "As set out in the Bulletin, the failure of a leniency applicant to comply with any of the terms and conditions of the plea agreement may result in revocation of the agreement. Where the Bureau becomes aware that an applicant does not meet the terms and conditions set out in its plea agreement, the Bureau may make a recommendation to the PPSC that the applicant's leniency be revoked. Typically, the Bureau will discuss the situation with the applicant and provide an opportunity to the applicant to address any shortfalls in its conduct as quickly as possible before making a recommendation for revocation to the PPSC.

As a result of the Bureau's recommendation, or on its own initiative, the PPSC may revoke a plea agreement where the applicant does not meet all of the terms and conditions of that agreement, and take further action against the applicant as appropriate in the circumstances." Tradução livre: "Tal como estabelecido no Boletim, o fracasso do candidato à leniência no cumprimento de qualquer um dos termos e condições do plea agreement pode resultar na sua revogação. Quando a Bureau tomar conhecimento de que um candidato à leniência não cumpre com os termos e condições estabelecidos em seu plea agreement, pode recomendar ao PPSC que revogue o pedido de leniência. Normalmente, a Bureau discutirá sobre essa situação com o candidato e lhe dará uma oportunidade de resolver quaisquer irregularidades em sua conduta o mais rápido possível antes de fazer uma recomendação pela revogação ao PPSC.

Como resultado da recomendação da Bureau, ou por iniciativa própria, o PPSC pode revogar um plea agreement quando o candidato não preencher os seus termos e condições, e tomar novas medidas contra o candidato, conforme as circunstâncias." (CANADA. COMPETITION BUREAU. Leniency program. FAQs).
} 


\subsubsection{Austrália}

Como último exemplo, na Austrália há uma grande preocupação com o combate aos cartéis, eis que são considerados ilícitos concorrenciais sujeitos a penalidades nas esferas civil e criminal.

Nessa ambiência, de rigor destacar que, inicialmente, as práticas cartelizadoras eram previstas pelo Trade Practices Act 1974 (atual Competition and Consumer Act 2010) apenas como infrações civis. Somente em 2009, o Parlamento australiano decidiu aprovar uma emenda a este normativo, denominada Trade Practices Amendment (Cartel Conduct and Other Measures) Act 2009, prevendo sanções criminais para os cartéis mais graves, de modo que se passou a permitir uma responsabilidade proporcional: sanções civis para as infrações mais leves e sanções criminais para as infrações mais sérias. ${ }^{399}$

Atualmente, as penalidades previstas para este ilícito anticompetitivo são as seguintes:

Já no que tange especificamente ao programa de imunidade, cf.: "As set out in Part F of the Bulletin, the failure of a party to comply with any of the terms and conditions in its immunity agreement may result in revocation of the agreement.

Where the Bureau becomes aware that an applicant does not meet the terms and conditions set out in its immunity agreement, the Bureau may make a recommendation to the DPP that the applicant's immunity be revoked. The Bureau will in the normal course discuss the situation with the applicant and provide a reasonable opportunity to the applicant to address any shortfalls in its conduct before making a recommendation to the DPP.

As a result of the Bureau's recommendation, or on its own initiative, the DPP may revoke an immunity agreement where the applicant does not meet all of the terms and conditions of that agreement, and take appropriate action against the party. Where the DPP determines that a party has failed to fulfil the terms and conditions set out in its immunity agreement, the DPP will provide fourteen (14) days written notice to the party before revoking the immunity agreement." Tradução livre: "Tal como estabelecido na Parte F do Boletim, o fracasso da parte no cumprimento de um dos termos e condições no seu immunity agreement pode resultar em revogação do acordo.

Quando a Bureau tomar conhecimento de que um candidato não cumpre os termos e condições estabelecidos no seu immunity agreement, ele pode recomendar ao DPP que o pedido de imunidade seja revogado. Normalmente, a Bureau discutirá a situação com o candidato e lhe dará uma oportunidade razoável de resolver quaisquer irregularidades em sua conduta o mais rápido possível antes de fazer uma recomendação pela revogação ao DPP.

Como resultado da recomendação da Bureau, ou por iniciativa própria, o DPP pode revogar um immunity agreement quando o candidato não cumprir os termos e condições desse acordo e tomar novas medidas contra o candidato. Quando o DPP determinar que o candidato fracassou no cumprimento dos termos e condições estabelecidos no seu immunity agreement, o DPP notificará a parte por escrito 14 dias antes de revogá-lo." (CANADÁ. COMPETITION BUREAU. Immunity program: frequently asked questions).

399 "The Parliament of Australia has passed the Trade Practices Amendment (Cartel Conduct and Other Measures) Act 2009 (the Act), which amended the Competition and Consumer Act 2010 (formerly the Trade Practices Act 1974) to provide criminal penalties for cartel conduct." (AUSTRÁLIA. AUSTRALIAN COMPETITION \& CONSUMER COMMISSION. Cartel conduct). 
"For individuals, the cartel offence is punishable by imprisonment of up to 10 years and/or fines of up to $\$ 220000$ per contravention.

Under the civil prohibition, individuals may be liable to a pecuniary penalty of up to $\$ 500000$ per contravention.

For corporations, the fine or pecuniary penalty for each contravention of the cartel offence or civil prohibition (whichever applies) will not exceed the greater of:

- $\$ 10000000$

- three times the total value of the benefits obtained by one or more persons reasonably attributable to the commission of the offence/act or omission in contravention of the civil prohibition

- where those benefits cannot be fully determined, 10 per cent of the corporate group's annual turnover in a 12-month period when the offence/contravention occurred.

Some of the other forms of relief available in relation to the cartel offence and civil prohibition include injunctions, orders disqualifying a person from managing corporations and community service orders." 400

Na Austrália, foi adotado um Programa de Leniência pela autoridade antitruste local chamada Australian Competition and Consumer Commission (ACCC), responsável por investigar práticas cartelizadoras e encaminhar os resultados das apurações que envolvam ilícitos concorrenciais mais graves - considerados, pois, infrações criminais - ao Commonwealth Director of Public Prosecution (CDPP), órgão acusatório australiano.

O procedimento de leniência é conduzido pela ACCC do início ao fim e, especificamente com relação às sanções civis, é ele o órgão responsável por conceder a

\footnotetext{
${ }^{400}$ Tradução livre: "Para pessoas físicas, a infração de cartel é punida com até 10 anos de prisão e/ou multas de até \$220.000 por violação. Com relação à infração civil, as pessoas físicas podem ser penalizadas com sanção pecuniária de até $\$ 500.000$ por violação. Para empresas, a multa ou sanção pecuniária para cada delito de cartel ou infração civil (qualquer que seja aplicável) não excederá: $\$ 10.000 .000$; três vezes o total do valor dos benefícios obtidos por uma ou mais pessoas razoavelmente envolvidas no cometimento do delito/ato ou omissão em violação da proibição civil; quando esses benefícios não puderem ser totalmente determinados, 10 por cento do faturamento anual do grupo empresarial no período de 12 meses, no qual o delito ou a contravenção ocorreu.

Algumas outras formas de punição disponíveis em relação ao delito de cartel ou infração civil inclui injunções, determinação de desqualificação de uma pessoa para gerir empresas e determinação de serviços comunitários." (AUSTRÁLIA. AUSTRALIAN COMPETITION \& CONSUMER COMMISSION. Cartel conduct).
} 
imunidade ao leniente. Já na esfera penal, somente o CDPP poderá conceder ou não a imunidade, após a recomendação da ACCC. ${ }^{401}$

Consoante a política adotada, uma empresa candidata ao Programa de Leniência somente será elegível para imunidade referente à persecução civil se preenchidas as seguintes condições:

“[...]

(i) the corporation is or was a party to a cartel

(ii) the corporation admits that its conduct in respect of the cartel may constitute a contravention or contraventions of the Competition and Consumer Act

(iii) the corporation is the first person to apply for immunity in respect of the cartel under this policy

(iv) the corporation has not coerced others to participate in the cartel and was not the clear leader in the cartel

(v) the corporation has either ceased its involvement in the cartel or indicates to the ACCC that it will cease its involvement in the cartel

(vi) the corporation's admissions are a truly corporate act (as opposed to isolated confessions of individual representatives)

(vii) the corporation undertakes to provide full disclosure and cooperation to the ACCC, and

(b) at the time the ACCC receives the application, the ACCC has not received written legal advice that it has sufficient evidence to commence proceedings

${ }^{401} \mathrm{Cf}$. "The ACCC will decide whether to grant immunity from civil proceedings in accordance with its published policy.

The CDPP will decide whether to grant immunity from criminal proceedings in accordance with the Prosecution Policy of the Commonwealth (including the Annexure to the policy) and upon the recommendation of the ACCC." Tradução livre: "O ACCC decidirá se concede imunidade civil de acordo com sua política publicada. O CDPP decidirá se concede imunidade criminal de acordo com a Prosecution Policy of the Commonwealth (incluindo o anexo da política) e com a recomendação do ACCC." (AUSTRÁLIA. AUSTRALIAN COMPETITION \& CONSUMER COMMISSION. Memorandum of understanding between commonwealth director of public prosecution and australian competition and consumer commission). 
in relation to at least one contravention of the Competition and Consumer Act

arising from the conduct in respect of the cartel." ${ }^{402}$

Paralelamente, a ACCC exige que "The corporation must ensure that its admissions and cooperation are truly corporate acts." 403

Insta registrar que, de início, a ACCC concede uma imunidade condicional, à espera do total cumprimento dos requisitos acima expostos, para somente ao final conceder a real imunidade. Todavia, tanto a imunidade condicional quanto a final podem ser revogadas pela ACCC se restar comprovado que o candidato não satisfez todas as condições. $^{404}$

Ainda considerando a hipótese de que o candidato à leniência é uma empresa, cumpre ressaltar que todos os seus diretores, executivos e funcionários (atuais ou já desligados da empresa) que admitirem o seu envolvimento na conduta cartelizadora e cooperarem plenamente com a ACCC serão elegíveis para a imunidade condicional da mesma forma que a empresa candidata. Ao final, se esses indivíduos continuarem

\footnotetext{
${ }^{402}$ Tradução livre: “[...] (i) a empresa faz ou fez parte de um cartel; (ii) a empresa admite que sua conduta cartelizadora pode constituir uma infração ou infrações previstas no Competition and Consumer Act; (iii) a empresa é a primeira a pedir imunidade com relação ao cartel, de acordo com esta política; (iv) a empresa não coagiu outros a participarem no cartel nem foi a líder evidente dele; (v) a empresa cessou o seu envolvimento no cartel ou indica ao ACCC que irá cessá-lo; (vi) a admissão da empresa é um verdadeiro ato corporativo (ao contrário de confissões isoladas de representantes individuais); (vii) a empresa comprometese a cooperar com o ACCC, e (b) no momento em que o ACCC recebe o seu pedido, não tenha opinião jurídica por escrito de que já possui provas suficientes para iniciar procedimentos ao menos com relação a uma infração do Competition and Consumer Act derivada da conduta cartelizadora." (AUSTRÁLIA. AUSTRALIAN COMPETITION \& CONSUMER COMMISSION. ACCC immunity policy for cartel conduct).

${ }^{403}$ Tradução livre: "A empresa deve assegurar que a sua admissão e cooperação são verdadeiros atos corporativos." (AUSTRÁLIA. AUSTRALIAN COMPETITION \& CONSUMER COMMISSION. ACCC immunity policy interpretation guidelines).

${ }^{404}$ Sobre a possibilidade de revogação do acordo, a política de imunidade do ACCC dispõe: "If, after the grant of conditional immunity or final immunity, the ACCC forms the view on reasonable grounds that the applicant does not or did not satisfy the conditions for immunity or conditional immunity referred to in paragraphs 8 and 10, it may revoke the grant of conditional immunity or final immunity. In this event the ACCC will provide the applicant with an opportunity to respond." Tradução livre: "Se, após a concessão da imunidade condicional ou final, a ACCC, baseado em motivos razoáveis, entender que o candidato não satisfaz ou não satisfez as condições para tanto referidas nos parágrafos $8^{\circ}$ e 10 , poderá revogar a sua concessão. Nesse caso, ela fornecerá ao candidato oportunidade para resposta." (AUSTRÁLIA. AUSTRALIAN COMPETITION \& CONSUMER COMMISSION. ACCC immunity policy for cartel conduct).
} 
colaborando com as investigações, a ACCC concederá a imunidade final simultaneamente à concessão da imunidade final corporativa. ${ }^{405}$

Quanto às pessoas físicas desvinculadas de qualquer leniência corporativa, isto é, que se apresentem independentemente, o Programa de Leniência australiano prevê a possibilidade de concessão de imunidade, condicionando o benefício aos mesmos requisitos exigidos para as empresas. De igual maneira, existe a possibilidade de revogação da imunidade.

Para a concessão da imunidade penal, a ACCC aplicará os mesmos requisitos que determinam elegibilidade nos termos de sua política de imunidade para fazer sua recomendação ao CDPP, mas a decisão final será sempre do CDPP. ${ }^{406}$

Ao revelar uma preocupante insegurança em sua política, a ACCC prevê que

\begin{abstract}
"Any statements or information provided pursuant to the corporate immunity application, including by the individual concerned, may then be used in any civil action the ACCC might take against the individual under the TPA for a substantive contravention or offence and further to any obstruction
\end{abstract}

\footnotetext{
${ }^{405}$ Cf. "[...] if a corporation qualifies for conditional immunity (see paragraph 8), all current and former directors, officers and employees of the corporation who admit their involvement in conduct of the corporation in respect of the cartel and provide full disclosure and cooperation to the ACCC will be eligible for conditional immunity in the same form as the corporation. (...) Subject to the current and former directors, officers and employees covered by derivative corporate immunity continuing to provide full disclosure and cooperation to the ACCC, the ACCC will grant them final immunity at the same time as it grants final immunity to the corporation." Tradução livre: "[...] se uma empresa se qualifica para uma imunidade condicional (veja parágrafo 8), todos os diretores, executivos e funcionários atuais ou já desligados da empresa que admitirem seu envolvimento na conduta cartelizadora da empresa e cooperarem com o ACCC serão elegíveis para a imunidade condicional da mesma maneira que a empresa (...) No que concerne aos diretores, executivos e funcionários (atuais ou já desligados da empresa) acobertados por uma imunidade corporativa derivada que continuem a cooperar com as autoridades, o ACCC lhes concederá imunidade final simultaneamente à concessão de imunidade final à empresa." (AUSTRÁLIA. AUSTRALIAN COMPETITION \& CONSUMER COMMISSION. ACCC immunity policy for cartel conduct).

${ }^{406}$ Sobre o tema, cf. "The ACCC will apply the same principles that determine eligibility under the ACCC's immunity policy when making a recommendation to the Commonwealth Director of Public Prosecutions (CDPP) that an immunity applicant be granted immunity from criminal prosecution." Tradução livre: "O ACCC aplicará os mesmos princípios que determinam elegibilidade de acordo com a política de imunidade do ACCC ao recomendar ao CDPP que um candidato receba a imunidade penal." (AUSTRÁLIA. AUSTRALIAN COMPETITION \& CONSUMER COMMISSION. ACCC immunity policy interpretation guidelines).
} 
proceedings in respect of contraventions of s. 155(5) of the TPA and/or proceedings relating to ss. $137.1,137.2$ or 149.1 of the Criminal Code." 407

Por fim, cumpre destacar a política de cooperação da ACCC destinada àqueles que não conseguem se eleger para a política de imunidade. É uma forma de conferir benefícios àquele que, embora não consiga preencher os requisitos do programa de imunidade, pretende cooperar com as investigações.

Tal política "[...] will both assist the ACCC to gather additional evidence that may help in the prosecution of cartel participants and allow the ACCC to negotiate an agreed penalty for recommendation to the court and thus avoid the need for contested litigation." 408

Em tese, nos termos dessa política, não é possível a concessão de imunidade total ao candidato, apenas um tratamento mais leniente. No entanto, a ACCC terá discricionariedade para imunizá-lo de acordo com sua conveniência. Também na esfera criminal, haverá possibilidade de concessão de imunidade, porém, nos termos da Prosecution Policy of the Commonwealth. ${ }^{409}$

\footnotetext{
407 Tradução livre: "Quaisquer depoimentos ou informações fornecidos de acordo com o pedido de imunidade corporativo, inclusive pelo indivíduo envolvido, podem ser usados em qualquer ação civil que o ACCC ingressar contra o indivíduo nos termos do TPA sobre uma contravenção ou infração substantiva e, ainda, em quaisquer procedimentos de obstrução com relação às contravenções previstas no s. 155(5) do TPA ou quaisquer procedimentos relacionados ao ss. 137.1, 137.2 ou 149.1 do Código Penal." (AUSTRÁLIA. AUSTRALIAN COMPETITION \& CONSUMER COMMISSION. ACCC immunity policy interpretation guidelines).

${ }^{408}$ Tradução livre: “[...] tanto auxiliará o ACCC a conseguir provas adicionais que poderão ajudar na acusação dos participantes do cartel quanto permitirá que o ACCC negocie uma sanção acordada para recomendação ao tribunal, evitando, assim, um litígio." (AUSTRÁLIA. AUSTRALIAN COMPETITION \& CONSUMER COMMISSION. ACCC immunity policy interpretation guidelines).

${ }^{409}$ Acerca da possibilidade de concessão de imunidade total, cf. "In general, a person will not be given full immunity under the cooperation policy. However, there are circumstances in which the ACCC may use its discretion under the cooperation policy to grant full immunity from ACCC initiated civil proceedings. Cartel participants who cooperate with the ACCC pursuant to the cooperation policy rather than the immunity policy will have their request for immunity from criminal prosecution determined in accordance with the Prosecution Policy of the Commonwealth per se, rather than pursuant to the annexure to that policy." Tradução livre: "Via de regra, uma pessoa não pode receber imunidade total na política de cooperação. No entanto, existem circunstâncias nas quais a ACCC pode usar sua discricionariedade na política de cooperação para conceder imunidade total nos procedimentos civis já iniciados. Os participantes de cartel que com ele cooperarem, nos termos da política de cooperação e não da política de imunidade, terão seu pedido de imunidade penal decidido de acordo com a Prosecution Policy of the Commonwealth per se e não de acordo com o anexo desta política." (AUSTRÁLIA. AUSTRALIAN COMPETITION \& CONSUMER COMMISSION. ACCC immunity policy interpretation guidelines).
} 
Tecidas essas considerações a respeito do Programa de Leniência de diversos países, urge registrar que o sistema jurídico adotado pela sua grande maioria ${ }^{410}$ é o Common Law, ${ }^{411}$ que diverge em absoluto do nosso sistema de Civil Law, ${ }^{412}$ de modo que é possível a análise de Direito Comparado tal como realizada, mas com ressalvas.

\title{
4.2 Acordo de Leniência e o Direito Penal
}

\subsubsection{Preocupações éticas}

\begin{abstract}
"O participante do cartel é como o escorpião: trair faz parte de sua natureza.
Pois furar o cartel constitui oportunidade de ouro para não elevar o preço (ou elevá-lo menos do que os concorrentes) e abocanhar boa parte da clientela."413
\end{abstract}

O estudo das provas em matéria criminal sempre apresentou grande dificuldade na valoração da delação, seja na fase policial, seja na judicial, com o conhecido instituto da chamada de corréu. ${ }^{414}$ Nos primórdios, com o Direito Romano, pouco valor era atribuído a esta chamada. Os romanos entendiam que da "[...] boca do réu era mais fácil ouvir a mentira que a verdade." ${ }^{415}$ Esse instituto encontrou sólida aplicação, mas a partir da consolidação do processo inquisitório na Idade Média, porquanto a confissão era o objetivo maior do processo penal àquela época. ${ }^{416}$

\footnotetext{
${ }^{410}$ Dentre os países estudados no presente capítulo, aqueles que adotam o sistema de Common Law são: Estados Unidos da América, Reino Unido, Canadá e Austrália. França e Grécia, por sua vez, adotam o sistema romano-germânico ou Civil Law.

${ }^{411}$ Em breves linhas, o Common Law é um sistema legal, no qual a principal fonte é a jurisprudência, seguindo a doutrina Stare Decisis, a qual estabelece que os juízes devem se sujeitar a precedentes estabelecidos pelos tribunais de instâncias superiores. É o direito que se desenvolve por meio de decisões dos tribunais e não mediante atos legislativos ou executivos. Por meio desse sistema, normas gerais são inferidas a partir de decisões judiciais proferidas em casos concretos.

${ }^{412} \mathrm{O}$ sistema de Civil Law ou romano-germânico, fundamentado no direito romano, é o mais disseminado no mundo e se caracteriza pela generalidade de suas normas jurídicas, que são aplicadas pelos magistrados aos casos concretos. Nesta sistemática, o direito é todo organizado em códigos e leis esparsas, prevalecendo o seu caráter escrito.

${ }^{413}$ OLIVEIRA, Gesner. A cenoura e o porrete contra os cartéis.

${ }^{414}$ Ainda que a maioria dos autores nacionais que se dedicam ao estudo do tema utilize a chamada do corréu como sinônimo de delação, em virtude de seu próprio nome, esta chamada somente ocorre na fase judicial, no bojo de uma ação penal. Em contrapartida, a delação pode se realizar tanto na fase judicial quanto na extrajudicial.

${ }^{415}$ ROSSETTO, Enio Luiz. A confissão no processo penal. P. 186.

${ }^{416}$ GEMAQUE, Silvio César Arouck. Chamada do co-réu. P. 47.
} 
Interessante notar que no sistema das provas legais, o chamamento do corréu era valorado de maneira inferior com relação ao depoimento de um estranho. Enquanto duas testemunhas faziam prova plena sobre um fato, três réus com depoimentos convergentes eram necessários para que se inculpasse outro acusado. ${ }^{417}$

Principalmente a partir do advento do processo penal acusatório, baseado no princípio do livre convencimento do juiz, a chamada do corréu passou a ser considerada prova frágil, que não se presta de per si para condenar, devendo ser analisada em conjunto com os demais elementos de prova. Por outro lado, a delação, já na modalidade premiada, sempre esteve presente na maioria dos principais regimes ditatoriais, senão institucionalizada, ao menos admitida:

"Era a forma escolhida pelos nazistas para pegar judeus, técnica de exportação adotada pelo governo de Vichy, aquele que traiu a França. Na Rússia de Stalin, chegou-se ao máximo da denúncia premiada erguendo estátuas ao menino Pavlik Morozov, condecorado e elevado a herói porque denunciara o pai que estava traindo os ideais socialistas.

Na Revolução de 64, também houve uma onda avassaladora de denuncismo e de caça aos infiéis." 418

Atualmente, a afirmativa feita por um acusado, por ocasião de seu interrogatório, pela qual, além de confessar a autoria por um fato criminoso, atribui a um terceiro a participação naquele delito, analisada sob o viés de seu valor probatório, ainda encontra grande divergência na doutrina e na jurisprudência.

Para Nicola FRAMARINO DEI MALATESTA, o valor da chamada do corréu decorre da seguinte razão:

\footnotetext{
"A facilidade para dizer a verdade sobre o próprio fato só pode, logicamente, levar à facilidade em dizer a verdade sobre o fato de outrem. Se não se ocultou a verdade sobre o fato delituoso próprio, mesmo tendo interesse em ocultá-lo, isto
}

\footnotetext{
${ }^{417}$ TORNAGHI, Helio. Instituições de processo penal. P. 392.

${ }^{418}$ SARNEY, José. Bordalesa e delação premiada.
} 
leva a supor que, com maior razão, se diga a verdade sobre fato alheio, não havendo interesse em ocultá-lo." ${ }^{419}$

Para muitos outros autores, o depoimento do cúmplice delator não tem valia alguma. MiTTERMAYER, por exemplo, reconhecia como “[...] natural que o cúmplice queira fazer recair sobre o co-autor do delito uma parte da sua falta." ${ }^{220}$ Assim, não conferiu força incriminadora à chamada do corréu, aduzindo:

\begin{abstract}
"O depoimento do cúmplice apresenta também grandes dificuldades. Têmse visto criminosos que, desesperados por conhecerem que não podem escapar à pena, se esforçam em arrastar outros cidadãos para o abismo em que caem; outros denunciam cúmplices, aliás, inocentes, só para afastar a suspeita dos que realmente tomaram parte no delito, ou para tornar o processo mais complicado ou mais difícil, ou porque esperam obter tratamento menos rigoroso, comprometendo pessoas colocadas em altas posições." 421
\end{abstract}

Pelos mesmos motivos, GENUZIO BENTINI considerava a chamada do corréu altamente suspeita e suscetível de falhas, um meio de prova extremamente inseguro. Por isso, afirmou que a "[...] chiamata di correo e riconoscimento sono le braccia della croce sulla quale si inchioda l'innocenza." ${ }^{422}$

O nosso ordenamento jurídico atual prevê o instituto da delação em diversas leis penais esparsas e determina que se premie essa atitude do colaborador com diminuições de pena ou até com perdão judicial. Não importa, para a legislação premial, se a delação é motivada por receio de punição, anseio pela liberdade, vingança, falta de caráter ou vontade de incriminar cúmplices. O instituto passa a ser válido desde que comprovada a espontaneidade e eficácia das declarações para a elucidação da verdade.

A absoluta ausência de padrões éticos e morais tornam inafastável a suspeição dos resultados obtidos por esse meio de prova. A premiação conferida ao delator instiga a

\footnotetext{
${ }^{419}$ DEI MALATESTA, Nicola Framarino. A lógica das provas em matéria criminal. P. 479.

${ }^{420}$ MITTERMAYER, Carl Joseph Anton. Prova em matéria criminal. P. 405.

${ }^{421}$ Idem. Tratado das provas em direito criminal. Pp. 295/296.

422 Tradução livre: "Chamada de corréu e reconhecimento são os braços da cruz sobre a qual se prega a inocência.” In: BENTINI, Genuzio, s/a, s/p. Apud CASTELO BRANCO, Fernando. Op. cit., p. 147.
} 
traição por parte daqueles que cometeram a prática delituosa, de maneira que os alcaguetes passam a falar verdades e/ou mentiras sobre os seus supostos cúmplices, a fim de atingir o prêmio máximo.

É notável que a dificuldade, ou incapacidade, do Estado em obter provas contundentes de um delito acaba por ser solucionada com a previsão do instituto da delação premiada em diversas leis, suscitando nos infratores a irresistível vontade de ceder à tentação, colaborando com as autoridades com o intuito de atingir as promessas de redução de pena e perdão judicial.

Assim sendo, haja vista a facilidade das investigações com o auxílio dos próprios envolvidos na prática delituosa, a delação passa a ser o meio de prova mais cobiçado pelas autoridades, ainda que essa escolha implique condutas imorais e antiéticas. Afora isso, essa opção pela delação acarreta um inegável comodismo por parte do Estado, que, incumbido do dever de investigar e perquirir a verdade real dos fatos, lança mão de um meio de prova excepcional como regra, evitando os demais meios admitidos em nosso ordenamento jurídico, mais lentos, mais custosos e talvez menos eficazes, porém em plena consonância com os direitos e garantias fundamentais. Como em um círculo vicioso, a dificuldade nas investigações leva à facilidade trazida pela delação, conduzindo ao comodismo das autoridades que embaraça ainda mais as apurações.

Em um Estado pautado em ideais democráticos, que prima pelo privilégio do Direito Penal mínimo e garantista, fazendo prevalecer o respeito aos direitos humanos, não é admissível a premiação de condutas que ferem frontalmente a ética e a moral, em alusão à máxima maquiavélica, segundo a qual "os fins justificam os meios”.

Cumpre observar que a responsabilidade pela escolha dessa via para o combate à criminalidade não é só do Estado, também a população, ávida por severas punições, encontra no delator a figura de um herói corajoso, merecedor de benevolência e perdão. Isto porque, a sensação de impunidade cresce à medida que se agrava a falência da capacidade investigativa do Estado, levando a uma incansável busca por soluções de resultados imediatos capazes de satisfazer os anseios sociais. Nesse contexto, as 
preocupações éticas são abandonadas para que se atinja um objetivo mais consistente na rápida prestação jurisdicional. ${ }^{423}$

Acerca da delação premiada, PAUlo SÉrgio LeITE Fernandes assim se pronunciou:

\begin{abstract}
"Autoridades diversas têm obtido algum sucesso, aparente embora, quando convencem incriminados à alcaguetagem, veraz ou não, de companheiros pecadores. No dicionário, a expressão vem de 'alcagote', sinônimo de alcoviteiro, tendo sentido, também, de mulher que fez mexericos, intrigas, intrigante, leva-e-traz. O povo já simplificou o vocábulo, dando-lhe o sentido de cáften, ou, em rude tradução, cafetão. Já se vê que a lei citada trata o delator com honrarias, embora os puristas não tenham vocação a tanto. Para os dicionaristas, membros ou não da Academia Brasileira de Letras (consultemse José Sarney e Marco Maciel), delator é alcagueta ou, ainda intermediário entre meretrizes (cáften). Voltando-se ao Brasil, a alcaguetagem premiada anda solta, significando transação entre o bandido e o mocinho. Em síntese, o primeiro confessa e "cafetaniza" (?) o companheiro, mediante paga. E paga é, porque há contraprestação da promessa de redução (...) Em síntese, delação cheira a cafetinagem. E o cáften é aquele que intermedeia (expressão esquisita mas correta) a relação entre o beneficiário e a realidade do prometido. O raciocínio é básico, mas Sócrates, se vivo estivesse, não o chamaria de sofisma. Apenas menearia a cabeça enquanto aprovando o silogismo." ${ }^{424}$
\end{abstract}

Ainda sobre a delação, TALES CASTELO BRANCO revelou que o instituto apresenta, sob o ponto de vista ético, dois pesos e duas medidas, pois traz: “[...] punições diferentes para procedimentos totalmente iguais, com recompensas especiais ao traidor, como se a traição fosse um valor positivo de caráter humano." "425 Também para ALBERTO SILVA FRANCO “[...] a delação premiada, qualquer que seja o nome que se lhe dê, e quaisquer que sejam as conseqüências de seu reconhecimento, continua a ser indefensável, do ponto de vista ético, pois se trata da consagração legal da traição que rotula, de forma definitiva, o papel do delator. ${ }^{426}$

\footnotetext{
${ }^{423}$ CASTELO BRANCO, Fernando. Op. cit., p. 148.

${ }^{424}$ FERNANDES, Paulo Sérgio Leite. Características da delação premiada. Ponto final.

${ }^{425}$ CASTELO BRANCO, Tales. Delação e cumplicidade criminosa.

${ }^{426}$ FRANCO, Alberto Silva. Crimes hediondos. P. 359.
} 
ROBERTO SOARES GARCIA contribui com o seu entendimento acerca da matéria:

\begin{abstract}
"Exatamente por não se poder aceitar que o Estado pratique ou incentive a prática de atos anéticos ou imorais, é que não se pode admitir a delação como forma de atenuar ou excluir a pena de quem pratica ou participa da prática de crime.

Ora, delação sempre é ato imoral e aético, já que a própria vida em sociedade pressupõe o expurgo da traição das relações sociais e pessoais. A quebra de confiança que se opera com a delação gera, necessariamente, desagregação, e esta traz a desordem, que não se coaduna com a organização visada pelo pacto social e com a ordem constitucional legitimamente instituída.

Não se venha dizer que a delação feita por quem vive à margem da lei contra outros marginais pode ser considerada ética e/ou moral, pois mesmo este caso envolve necessariamente traição, violação às regras de conduta vigentes em determinada situação. É que a delação promovida por criminoso em desfavor de outro não apaga a aeticidade e/ou imoralidade intrínsecas à traição, não valendo, aqui, a regra que vige na operação matemática de multiplicação, em que 'menos com menos dá mais'. (...) Por isso, além de ser totalmente inconveniente - pois incentiva conduta desagregadora, imoral e anética -, a chamada delação premiada mostra-se inconstitucional, incompatível com os princípios fundantes da sociedade brasileira, retratados na Constituição Federal de 1988." 427
\end{abstract}

Não há como negar, portanto, que a carência de eticidade repercute diretamente na juridicidade da delação premiada, sobretudo em face dos princípios da dignidade da pessoa humana (artigo $1^{\circ}$, III da Constituição Federal) e das garantias constitucionais da liberdade e do devido processo legal (artigo $5^{\circ}$, caput, e LIV da Carta Magna).

Destarte, com a delação, o Estado põe fim à harmoniosa relação entre a ética, a moral e o Direito. Isto porque, conforme acentua JosÉ RENATO NALINI, dentre as formas de comportamento humano, a jurídica é a que guarda maior intimidade com a moral; “[...] é com base na profunda vinculação moral/direito que se pode estabelecer o relacionamento

${ }^{427}$ GARCIA, Roberto Soares. Delação premiada: ética e moral, às favas. 
ética/direito. Pois ética não é senão a ciência do comportamento moral do homem na sociedade. ${ }^{, 428}$

Nessa ordem de ideias, é relevante mencionar lição de MiguEl REALE sobre a relação entre Direito e Moral. Ao discorrer sobre a teoria do "mínimo ético", já exposta de certa maneira pelo filósofo inglês Jeremias Bentham e, posteriormente, desenvolvida por uma série de autores, assim registrou:

\begin{abstract}
"A teoria do "mínimo ético" pode ser reproduzida através da imagem de dois círculos concêntricos, sendo o círculo maior o da Moral, e o círculo menor o do Direito. Haveria, portanto, um campo de ação comum a ambos, sendo o Direito envolvido pela Moral. Poderíamos dizer, de acordo com essa imagem, que ‘tudo o que é jurídico é moral, mas nem tudo o que é moral é jurídico'.

(...)

Há pois que distinguir um campo de Direito que, se não é imoral, é pelo menos amoral, o que induz a representar o Direito e a Moral como dois círculos secantes. Podemos dizer que dessas duas representações - de dois círculos concêntricos e de dois círculos secantes, - a primeira corresponde à concepção ideal, e a segunda à concepção real, ou pragmática, das relações entre o Direito e a Moral." 429
\end{abstract}

Desse modo, ainda que se considere a parcela do Direito fora do círculo secante da Moral, ela nunca permitiria um ato imoral, mas, ao máximo, amoral, lembrando não ser esta a concepção ideal deste relacionamento. Direito e Moral são realidades distintas, mas não separadas, fazendo-se necessária a sua convivência em harmonia.

Nessa esteira, o mesmo autor asseverou que “[...] o Direito como experiência humana, situa-se no plano da Ética, referindo-se a toda a problemática da conduta humana subordinada a normas de caráter obrigatório."

Nesse contexto, conclui-se que o acordo de leniência, à semelhança da delação premiada, representa um instrumento antiético de obtenção de provas, um dos responsáveis pela dissociação entre Direito e Moral.

\footnotetext{
${ }^{428}$ NALINI, José Renato. Ética geral e profissional. P. 30.

${ }^{429}$ REALE, Miguel. Lições preliminares de direito. Pp. 42/43.

${ }^{430}$ Idem. Filosofia do direito. P. 37.
} 
O acordo apresenta-se como um desprezível meio de obtenção de confissão exclusivamente baseado na traição, seja pela sedução moral de obtenção dos benefícios de redução da sanção penal ou extinção da punibilidade, seja pela coação psicológica, em virtude da alta possibilidade de seu envolvimento na prática delituosa ser descoberto ou delatado por outro participante.

Em consequência, seus resultados revelam-se suspeitos e duvidosos, eis que imbuídos por uma inegável transgressão ética e moral. Não se sabe ao certo se verdades são descobertas ou mentiras são fantasiadas, pois há uma desenfreada luta pelo reconhecimento do cumprimento do acordo de leniência a qualquer custo, para que o leniente, enfim, tenha alguma recompensa pela traição. Indubitavelmente, não há qualquer interesse do candidato à leniência em colaborar, de fato, com a justiça nem mesmo uma súbita conversão de seu espírito para o bem, com uma inesperada preocupação com aquilo que é verdadeiro e justo. O interesse, nesse caso, é sempre individual e egoísta. ${ }^{431}$

Nos dizeres de Danilo Ferraz Córdova e Mariana Rebuzzi Sarcinelli LoPes, “[...] pode-se inferir que se trata de um instrumento que parte da prévia ciência da instabilidade interna dos cartéis, da questionável 'lealdade', entre os que dele participam e da idéia de premiar aqueles que colaboram com o Estado, em troca de benefícios pessoais. "432

Nessa linha, em julgamento realizado pela Quarta Turma do Tribunal Regional Federal da $3^{\text {a }}$ Região, AldA BASTOS assim se pronunciou a respeito do seu entendimento sobre a validade do instituto:

\footnotetext{
"Como deixei assinalado, não recepciono o acordo de leniência como instrumento suficiente a embasar busca e apreensão, assemelhando-se à delação, pois por si é eticamente condenável, posto que, seu autor como partícipe da conduta ilegal detém moral questionável para servir de prova." ${ }^{433}$ (grifos no original)
}

\footnotetext{
${ }^{431}$ MARCÃO, Renato. Delação premiada. P. 160.

${ }^{432}$ CÓRDOVA, Danilo Ferraz; LOPES, Mariana Rebuzzi Sarcinelli. Op. cit., p. 69.

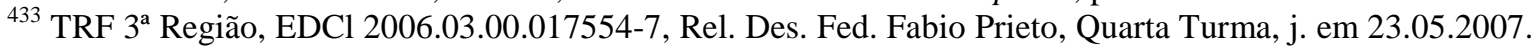
(grifos nossos)
} 
Miguel REALE JÚNIOR, em palestra proferida por TÉRCIO SAMPAIO FERRAZ JÚNIOR, manifestou-se sobre o assunto:

\begin{abstract}
“A americanização do Direito, especialmente nessa área, o problema da leniência, passa por cima de qualquer princípio ético. É o autor do fato delituoso, que se mantém beneficiário, até o instante em que vê a casa cair e denuncia os seus comparsas. E o Estado se vale do delator, do covarde, para querer condenar os outros. É o Estado anti-ético, que alimenta a delação. Até o criminoso tem de ter a sua dignidade." ${ }^{, 434}$
\end{abstract}

Nessa toada, causa estranheza o disposto no artigo 73, inciso IX, da Portaria do Ministério da Justiça $n^{\circ} 456$, de 15 de março de 2010, ${ }^{435}$ acerca das obrigações do signatário do acordo de leniência, exigindo do leniente uma postura honesta, leal e de boafé.

Ora, o beneficiário do acordo, de fato, não promoveu a delação sob o manto da honestidade, da lealdade e da boa-fé, ao menos não com relação aos demais partícipes da atividade criminosa. Portanto, seria, no mínimo, contraditório exigir do leniente uma postura desonesta e de má-fé para com os demais membros do cartel, no ato da delação, e uma atitude de todo oposta no momento de colaboração com as autoridades antitruste.

Ademais, insta ressaltar a possibilidade de, com essas medidas, o Estado promover e alimentar um denuncismo desenfreado cometido a qualquer preço. Com o intuito de livrar-se do processo penal ou ver sua pena reduzida, o agente infrator é capaz de produzir informações de todo o tipo, verídicas ou não, para ver cumpridos os requisitos do acordo. Nestes casos, sem apego algum à tão almejada postura honesta, leal e de boa-fé.

A par disso, seguindo o mesmo raciocínio referente à delação premiada, paulatinamente o acordo de leniência vem sendo considerado pelas autoridades antitruste o único instrumento de combate aos cartéis, ainda que vários outros métodos triviais de investigação sejam disponibilizados para a apuração deste tipo de infração.

\footnotetext{
${ }^{434}$ FERRAZ JÚNIOR, Tércio Sampaio. Indício e prova de cartel. In: Estudos - Documentos, $\mathbf{n}^{\circ}$ 24, Reunião do Conselho Superior de Assuntos Jurídicos e Legislativos (CONJUR).

435 “[...] Art. 73. Do instrumento do Acordo de Leniência, firmado com a União, por intermédio da Secretaria de Direito Econômico, nos termos dos artigos 35-B e 35-C, da Lei $n^{o}$ 8.884, de 1994, deverão constar as seguintes cláusulas e condições: (...) IX - obrigações do signatário do Acordo de Leniência: (...) g) portar-se com honestidade, lealdade e boa-fé durante o cumprimento dessas obrigações.”
} 
Mesmo tecidas todas essas ponderações que levam à irrefutável constatação da violação da ética e da moral pelo acordo de leniência e da traição estimulada a qualquer preço pelo instituto, não se pode ignorá-lo como realidade fática dos tempos modernos. Em que pese seja pautado por esteios absolutamente contestáveis, é mister seja ele reconhecido como um dos instrumentos de combate a cartéis mais utilizado pelas autoridades antitruste de todo o mundo.

Outrossim, considerando o acordo de leniência como inegável dado da realidade, torna-se imperiosa uma análise crítica sobre a sua regulamentação e, sobretudo, com relação aos seus reflexos na seara penal, a fim de adequá-lo ao ordenamento jurídico pátrio e garantir ao leniente a segurança jurídica a que tem direito. Ignorá-lo apenas em razão de preocupações éticas não excluirá o instituto de nossa legislação, de tal sorte que elaborar uma regulamentação à luz de princípios constitucionais sobre o tema é a melhor solução.

\subsubsection{Reflexos penais}

\subsubsection{Discricionariedade, transparência e segurança jurídica}

O impacto gerado pelo acordo de leniência na esfera penal não vem sendo muito aplaudido, em razão dos critérios subjetivos e obscuros que permeiam a sua celebração e, sobretudo, os seus resultados. O acordo de "abrandamento", ao invés de representar um estímulo à delação e à consequente destruição da ação criminosa dos cartéis, tem se revelado fator de inestimável risco ao delator, provocando uma indesejada insegurança jurídica.

$\mathrm{Na}$ realidade, a perspectiva de premiação do leniente consubstancia-se em algo absolutamente incerto, calcado em elementos subjetivos que induzem o candidato à não celebração do acordo. Esta temível insegurança coloca em risco a própria eficácia do instituto, prejudicando, substancialmente, a boa investigação dos delitos contra a ordem econômica e, em especial, o cartel.

Na hipótese de o leniente não se sentir seguro de que logrará êxito na obtenção dos benefícios penais do instituto ou não compreender os termos e a lógica do Programa de 
Leniência quanto aos seus requisitos, condições e reflexos na esfera penal, por certo o proponente optará pela via mais cômoda e, para ele, mais garantida - da permanência na atividade ilícita, sem a comunicação às autoridades antitruste. ${ }^{436}$ Isto porque, é inexorável que a confissão daquele que participa no delito de cartel poderá transformar-se em instrumento autoincriminatório. Logo, sem a certeza da concordância da Secretaria de Direito Econômico com o acordo de leniência e da extinção da punibilidade na esfera penal como consequência, a confissão passa a representar prova robusta para a propositura de uma ação penal. ${ }^{437}$

Urge destacar que, para a obtenção da tão esperada extinção da punibilidade na esfera penal, o autor da infração deverá, por meio do acordo, colaborar efetivamente com as investigações - por meio da confissão -, resultando dessa colaboração a necessária identificação dos demais coautores e a obtenção de informações e documentos que comprovem a infração noticiada ou sob investigação (artigo 35-B, caput, I e II, da Lei $n^{\circ}$ 8.884/90); ou seja, a própria efetividade ou não da colaboração passará, necessariamente, pelo espectro valorativo e subjetivo do julgador. O que representa para a Secretaria de Direito Econômico a comprovação da infração contra a ordem econômica? Elementos indiciários? Provas inequívocas? Materialidade comprovada e indícios suficientes da autoria da infração aptos a ensejar um oferecimento de denúncia na esfera penal?

As respostas a tais perguntas são de todo desconhecidas - talvez apenas presumidas -, pois o legislador preferiu não evidenciar as suas pretensões quanto ao requisito básico do Programa de Leniência concernente ao consistente resultado da colaboração. Desta feita, fica a critério da Secretaria de Direito Econômico decidir quais informações e documentos preenchem o requisito legal para admissibilidade do candidato ao acordo. ${ }^{438}$

\footnotetext{
${ }^{436}$ SHERIDAN SCOTT, em palestra proferida para a FIESP, em 12 de maio de 2008, desde o início alertou para a imprescindibilidade em "[...] fornecer o máximo de transparência e previsibilidade possível ao programa de leniência (...) no intuito de incentivar as partes a requerer a leniência."

Com base em sua vasta experiência no assunto como presidente do setor de concorrência do Competition Bureau Canada e da International Competition Review, o autor assim se pronunciou: “[...] por esse motivo, publicamos um boletim que explica detalhadamente como funciona o programa de leniência do Bureau. Ele esclarece a análise feita pelo Bureau ao elaborar suas recomendações no tocante a aplicação de multa e redução de penas, em razão da leniência. O boletim explica também as etapas envolvidas no processo de leniência para que as empresas saibam o que esperar quando entram em contato conosco."

${ }^{437}$ CASTELO BRANCO, Fernando. Op. cit., p. 155.

${ }^{438}$ A esse respeito, AMADEU RIBEIRO e MARIA EUGÊNIA NOVIS abordam situação interessante que destaca a relevância da questão: “Imagine-se a situação do proponente que não disponha de um 'revólver fumegante', mas que seja capaz de trazer à SDE indícios da existência da infração que possa levá-la a coletar provas robustas mediante, por exemplo, busca e apreensão nas instalações de outro membro do cartel. Tal
} 
Também estão a revelar um alto grau de subjetivismo do acordo os requisitos contidos nos $\S \S 1^{\circ}$ e $2^{\circ}$ do artigo 35 , da Lei $n^{\circ} 8.884 / 94$. Para a elegibilidade do leniente, exige-se, dentre outros, que o candidato não tenha estado "[...] à frente da conduta tida como infracionária[...] $]^{439}$ ou que seja "[...] o primeiro a se qualificar com respeito à infração noticiada ou sob investigação." 440

Vale lembrar que o primeiro modelo norte-americano de acordo de "lenidade" fracassou exatamente devido ao elevado nível de subjetivismo e discricionariedade do Departamento de Justiça no momento de conceder a anistia, sofrendo intensa modificação em $1993 .^{441}$

Ao seguir o mesmo caminho, a União Europeia submeteu seu Programa de Leniência, em 2002, a uma profunda reforma, buscando torná-lo mais atraente e eficaz; erradicou fórmulas discricionárias aumentando as possibilidades dos infratores de obterem a imunidade penal. ${ }^{442}$

Como definir que o pressuposto leniente foi o primeiro a se qualificar? Será o primeiro a protocolar sua proposta? E se esta for realizada verbalmente? E, ainda, na hipótese de um concorrente, na corrida à leniência, for o segundo colocado, mas trouxer maiores informações a respeito do mesmo cartel, não será o primeiro preterido? Qual a garantia oferecida aos candidatos? De fato, nenhuma.

É bem verdade que foi criado um sistema de senhas (marker system) para proteger a posição de um candidato na fila para o acordo de leniência, entretanto, este é válido apenas para aquele que não possuir todas as provas e informações necessárias para ser

proponente talvez viesse a ter sua proposta recusada pela SDE em virtude de não dispor de provas cabais do ilícito. Em vista desse risco, é provável que relute em se apresentar às autoridades, o que evidentemente reduz a efetividade do programa." (RIBEIRO, Amadeu; NOVIS, Maria Eugênia. Programa brasileiro de leniência: evolução, efetividade e possíveis aperfeiçoamentos. P. 163).

439 Ao analisar a expressão, RODOLFO TIGRE MAIA observa que, a par de seu subjetivismo, "[...] tal exigência, ao que parece, conduz à eventual violação ao princípio da igualdade e desconsidera que, etiologicamente, o que se persegue precipuamente com estes acordos é a cessação mais célere da atividade lesiva. Ao que se acrescenta, também, a existência de notórias dificuldades técnicas inatas à apuração destes casos, que recomendam a perspectiva de tornar mais abrangente o dispositivo, permitindo sua utilização pelos demais envolvidos, sejam eles autores, co-autores, partícipes ou cúmplices.” (MAIA, Rodolfo Tigre. Op. cit., p. 237).

${ }^{440}$ A título de informação, o deputado CARLOS BEZERRA apresentou o Projeto de Lei no 3.434/08, que permite àquelas pessoas físicas que não se qualificaram em primeiro lugar junto à SDE também celebrar acordo de leniência.

${ }^{441}$ Cf. VALÉRIO, Marco Aurélio Gumieri. Acordo de leniência: a delação premiada como instrumento de combate ao cartel. P. 190.

${ }^{442}$ Idem, ibidem, p. 191. 
admitido pela Secretaria de Direito Econômico. ${ }^{443}$ Não se sabe qual o procedimento para a classificação dos candidatos detentores de provas e documentos.

De igual modo, é incógnito o significado da expressão "estar à frente da conduta tida como infracionária". Na tentativa de estabelecer uma definição para os termos legais, a Portaria do Ministério da Justiça $n^{\circ}$ 456/2010, em seu artigo 61, parágrafo único, registrou que "[...] não serão consideradas como tendo estado à frente da infração noticiada partes que desempenharem papéis equivalentes em seu funcionamento."444

Sabe-se o que não caracteriza a expressão, mas o que exatamente pretendeu o legislador com essa vedação? Qual seria o parâmetro utilizado pela autoridade antitruste para identificar as empresas e diretores impossibilitados de pactuar?

A própria Secretaria de Direito Econômico admite a dificuldade em se definirem os termos da lei, ressaltando que “[...] em muitos cartéis, não é possível identificar um líder. O mero fato de uma empresa ter agendado uma reunião ou mantido arquivos do cartel não necessariamente a desabilita como potencial beneficiária do Acordo de Leniência, "445

Ainda no $\S 2^{\circ}$, do artigo 35, o legislador estabelece que o acordo só poderá ser celebrado se a Secretaria de Direito Econômico não dispuser de “[...] provas suficientes para assegurar a condenação da empresa ou pessoa física [...]" sem que se defina o que são "provas suficientes”. Aliás, se este órgão dispusesse de provas suficientes para assegurar a condenação, sequer seria necessário um processo penal ou administrativo para averiguar a responsabilidade da empresa ou pessoa física infratora, pois o decreto condenatório seria certo - se é que isso é possível - em um nítido desprezo aos princípios constitucionais do devido processo legal, da ampla defesa e do contraditório (artigo $5^{\circ}$, incisos LIV e LV).

\footnotetext{
${ }^{443}$ Ver artigo 61, da Portaria do Ministério da Justiça no 456/2010.

444 Deve-se reconhecer, todavia, que esse esclarecimento já dissolve a crítica realizada por FERNANDO CASTElO BRANCO, ao mencionar o seguinte exemplo: "Tomemos como exemplo a seguinte situação: três empresas, por meio de ajuste prévio de seus diretores e abusando do poder econômico, dominam o mercado e eliminam totalmente seus concorrentes. No caso hipotético, altamente factível, todos foram, igualmente, mentores intelectuais e, consequentemente, co-autores do conluio. Qual seria, portanto, o parâmetro adotado pela SDE para identificar a(s) empresa(s) e respectivos diretores impossibilitados de pactuar? Ou seja, pelo sistema legal adotado, nenhum deles, "pessoas físicas e jurídicas”, estaria apto à celebração do acordo de leniência.” (CASTELO BRANCO, Fernando. Op. cit., p. 152).

${ }^{445}$ BRASIL. MINSTÉRIO DA JUSTIÇA. SECRETARIA DE DIREITO ECONÔMICO. Cartilha sobre combate a cartéis e programa de leniência. P. 29.
} 
Ao final deste parágrafo o legislador exige como outro requisito a colaboração plena e permanente com as investigações e o processo administrativo em mais um nebuloso jogo de palavras, que está a demonstrar os critérios subjetivos para elegibilidade do leniente. ${ }^{446}$

Não bastasse esse conjunto de vagos e imprecisos requisitos para a admissibilidade e celebração do acordo, o mesmo dispositivo legal revela mais uma fonte de discricionariedade e subjetivismo das autoridades no programa.

Conquanto o $\$ 4^{\circ}$ do artigo $35-\mathrm{B}$ da Lei $\mathrm{n}^{\circ} 8.884 / 94$ determine, por um lado, que “[...] a celebração de acordo de leniência não se sujeita à aprovação do CADE [...]”, de outro, assinala suas atribuições tão logo por ele “[...] verificado o cumprimento do acordo. ${ }^{, 447}$

A redação da Portaria do Ministério da Justiça nº 456/2010 é ainda mais clara:

\section{“[...]}

Art. 75. Uma vez declarado o cumprimento do Acordo de Leniência pelo

Conselho Administrativo de Defesa Econômica, será decretada em favor do signatário do Acordo de Leniência:

I - a extinção da ação punitiva da administração pública, nas hipóteses em que a proposta do Acordo de Leniência tiver sido apresentada à Secretaria de Direito Econômico sem que essa tivesse conhecimento prévio da infração noticiada; ou

\footnotetext{
${ }^{446}$ A Cartilha sobre combate a cartéis e programa de leniência da Secretaria de Direito Econômico assinala que "Se um candidato ao Programa de Leniência deliberadamente enganar a SDE, fornecer provas falsas, omitir ou destruir provas ou, de qualquer modo, comportar-se de maneira inconsistente com o requisito de cooperação plena e ampla, a SDE informará ao CADE que o Acordo de Leniência não foi devidamente cumprido e que os benefícios não devem ser concedidos." (BRASIL. MINISTÉRIO DA JUSTIÇA. SECRETARIA DE DIREITO ECONÔMICO. Cartilha sobre combate a cartéis e programa de leniência. P. 28, grifos nossos) Também essa orientação não serve de amparo ao candidato a leniente.

447 “[...] Art. 35-B (...) $\$ 4^{\underline{o}}$ A celebração de acordo de leniência não se sujeita à aprovação do CADE, competindo-lhe, no entanto, quando do julgamento do processo administrativo, verificado o cumprimento do acordo:

I - decretar a extinção da ação punitiva da administração pública em favor do infrator, nas hipóteses em que a proposta de acordo tiver sido apresentada à SDE sem que essa tivesse conhecimento prévio da infração noticiada; ou

II - nas demais hipóteses, reduzir de um a dois terços as penas aplicáveis, observado o disposto no art. 27 desta Lei, devendo ainda considerar na gradação da pena a efetividade da colaboração prestada e a boa-fé do infrator no cumprimento do acordo de leniência."
} 
II - Nas demais hipóteses, a redução de um a dois terços das penas aplicáveis na seara administrativa.

Parágrafo único: Nas duas hipóteses referidas acima, extingue-se automaticamente a punibilidade dos crimes tipificados na Lei $\mathrm{n}^{\circ} 8.137$, de 27 de novembro de 1990." (grifos nossos)

Isto significa que, embora não caiba ao CADE decidir e participar na análise dos requisitos para admissibilidade do pressuposto leniente, bem como na celebração do acordo de leniência, o seu cumprimento passa, obrigatoriamente, pelo crivo de seus conselheiros.

Destarte, mesmo que a Secretaria de Direito Econômico entenda que todos os requisitos para admissibilidade do candidato à leniência foram devidamente preenchidos e prossiga com a celebração do acordo, o instrumento firmado passará por uma segunda avaliação, realizada pelos conselheiros do CADE. De nada valerá a decisão da Secretaria se, posteriormente, consoante os critérios dos conselheiros, o acordo for julgado inválido. Não basta firmá-lo para a obtenção de seus benefícios, pois somente após a homologação da decisão da Secretaria de Direito Econômico pelo CADE, a leniência surtirá efeito.

Aliás, não são públicos os critérios utilizados pelos conselheiros para essa análise. É possível que nova avaliação seja feita à luz dos mesmos requisitos impostos pela Lei $\mathrm{n}^{\circ}$ 8.884/94, já observados pela Secretaria de Direito Econômico em uma dupla fiscalização, porém não há segurança alguma quanto a isso. ${ }^{448}$

Assim sendo, a tão desejada extinção da punibilidade com relação aos crimes contra a ordem econômica, apesar de automática, somente será declarada após a análise dos termos do acordo pelo CADE, de modo que se torna morosa, duvidosa e incerta a contraprestação do Estado pela delação obtida, ou seja, nada tem de automática.

Sobre essa atribuição do CADE, assim se manifestou FERnANDo CASTElo BRANCO:

\footnotetext{
${ }^{448}$ A Cartilha sobre combate a cartéis e programa de leniência apenas salienta que "[...] ao julgar o caso, se o CADE verificar que o Acordo de Leniência foi cumprido, extingue-se automaticamente a punibilidade dos crimes previstos na Lei de Crimes contra a Ordem Econômica.” (BRASIL. MINISTÉRIO DA JUSTIÇA. SECRETARIA DE DIREITO ECONÔMICO. Cartilha sobre combate a cartéis e programa de leniência. P. 21).
} 
"Apesar de o dispositivo legal não sujeitar a celebração de acordo de leniência 'à aprovação do CADE', paradoxalmente, exige do Conselho 'quando do julgamento do processo administrativo', verificar 'o cumprimento do acordo' (art. 35-B, $\S 4^{\circ}$, da Lei n. 8.884/94).

Em outras palavras, a SDE atrai o leniente com a sedutora oferta de extinção da punibilidade na esfera penal, ao mesmo tempo em que impõe condutas e exige providências. Contudo, a celebração do acordo não lhe dá a eficácia plena ou validade imediata, porque depende da decisão final do CADE.

Esta sujeição futura, por mais que se tente subestimá-la ou transformá-la em mero ato protocolar, existe e deve ser considerada pelo leniente como novo fator de risco para a pretensa extinção da punibilidade na esfera penal.

(..)

Assim, pautado no livre convencimento dos seus conselheiros, o CADE, quando do julgamento do processo administrativo, poderá entender que o acordo de leniência não foi devidamente cumprido, detectar falha incontornável na sua celebração, ou ainda, vislumbrar a existência de qualquer vício formal.

Em qualquer dessas possíveis situações, o risco e o prejuízo recairão integralmente sobre o leniente, porquanto o acordo anteriormente firmado poderá não ser homologado." 449

No Relatório de sugestões de aperfeiçoamento do programa de leniência brasileiro, elaborado em agosto de 2008 por um Grupo de Trabalho para Discussão sobre o Programa de Leniência da Secretaria de Direito Econômico, por iniciativa da Diretoria do IBRAC, demonstrou preocupação com a questão:

"No Brasil, o benefício final deverá ser outorgado pelo CADE, que analisará se todas as condições impostas foram efetivamente cumpridas pela empresa. A SDE deverá emitir ainda relatório discorrendo sobre o cumprimento destas condições, o qual não vincula o CADE na sua decisão. Apesar da existência de discricionariedade quanto ao cumprimento ou não das condições legais, a outorga do benefício é automática.

Eis, nesse sentido como dito acima, outra fragilidade que abarca o instituto da leniência no Brasil, porquanto a Constituição Federal de1988 outorga ao juiz

${ }^{449}$ CASTELO BRANCO, Fernando. Op. cit, p. 159. 
de direito o exercício privativo da jurisdição, notadamente em matéria penal, de modo que, a constitucionalidade da Lei que instituiu a Leniência mostra-se frágil, pois o CADE, órgão administrativo, é incumbido de extinguir a punibilidade criminal do signatário do acordo de leniência.

Neste sentido, uma das alterações no programa de leniência norte-americano veio no sentido de garantir que o benefício seja automático uma vez que preenchidas as condições. Nos EUA, o magistrado do juízo em que corre o processo de cartel será o responsável pela outorga final do benefício.

Na Europa, a Unidade da Comissão Européia responsável pela assinatura do Acordo de Leniência é a mesma responsável pela instrução do processo e, a mesma que concede, de maneira final, o benefício ao requerente." 450

Por conseguinte, conclui-se que a celebração do acordo não lhe atribui eficácia plena. A atraente proposta de imunidade penal imediata prometida pelo legislador que cativa os infratores, conduzindo-os rapidamente às autoridades antitruste para firmar o acordo, não é segura. Basta uma análise detida da Lei de Defesa da Concorrência para se observar que não há garantia alguma do momento da validade do benefício e tampouco de sua própria concessão.

Não à toa, Danilo Ferraz Córdova e Mariana Rebuzzi Sarcinelli LoPeS entendem que a redação confusa da lei desencoraja os supostos infratores a aderir ao programa, ressaltando que, com a regulamentação vigente, foram escassos os acordos de leniência firmados com a Secretaria de Direito Econômico, de maneira que é evidente a necessidade de revisão de suas normas para que tenha mais eficiência. ${ }^{451}$

Não é demais destacar que o acordo de leniência é pautado unicamente em um atraente prêmio concedido ao colaborador. A traição e o abandono da prática ilícita - frisese, extremamente lucrativa - acabam por ser recompensados pelas consequências previstas nos âmbitos administrativo e penal.

Em virtude disso, é imprescindível que as diretrizes do Programa de Leniência sejam expostas de forma clara e precisa aos proponentes. Cientes das sanções administrativas e penais a que estão sujeitos pela prática de condutas anticoncorrenciais e sabedores dos benefícios oferecidos pelo instituto da leniência, os infratores poderão 
escolher livremente a via que melhor lhe convier. Nessa ordem de ideias, JULIANA GIRARDELLI VILELA enfatiza o significado do binômio risco/recompensa para o agente infrator:

\begin{abstract}
"Outro fator de suma importância para reprimir a prática de cartéis é que seus riscos devem ser maiores que as eventuais recompensas geradas pela atividade ilícita, e as empresas e seus executivos devem ter essa percepção. Se assim não for, as sanções previstas serão entendidas tão somente como um mero custo a ser computado para a realização do negócio." ${ }^{452}$
\end{abstract}

Destarte, é recomendável que se caminhe para um fortalecimento da legislação antitruste no sentido de se trazer maior segurança aos candidatos à leniência para que, ao invés de afastá-los, as autoridades atinjam o fim pretendido de atraí-los para a delação, ${ }^{453}$

\footnotetext{
${ }^{452}$ A título de ilustração, a autora relata o caso da F. Hoffman-La Roche (HLR) e sua participação no cartel mundial de vitaminas: "Em 1997, cerca de dois anos antes de a conspiração das vitaminas ter sido exposta, $a$ HLR foi condenada por sua participação no cartel internacional do ácido cítrico. A organização aceitou cooperar com as autoridades antitruste, e lhe foi ordenada uma multa de 14 milhões de Dólares. A Divisão entrevistou dois altos executivos da HLR que haviam participado da conspiração do ácido cítrico e que tinham, também, responsabilidades no caso das vitaminas. Contudo, a HLR e seus executivos negaram conhecimento e participação nesse cartel. Porém, mais tarde, a Divisão descobriu que eles participavam deste cartel e continuavam a comandá-lo mesmo após terem sido declarados culpados por participarem do cartel do ácido cítrico. Tal condenação não foi suficiente para conter suas práticas anticoncorrenciais, $e$ eles continuaram liderando outros cartéis mundiais. Fica claro, assim, que uma multa de 14 milhões de Dólares não foi pertinente para inibi-los, mas 500 milhões de Dólares em multa mais a sentença de prisão para os executivos trouxeram os resultados esperados." (VILELA, Juliana Girardelli. Op. cit., pp. 204/205).

${ }^{453}$ Incentivar as empresas a buscar o acordo de leniência sempre foi o objetivo maior das autoridades norteamericanas. Por isso, ScotT D. HAMMOND conclui seu trabalho asseverando: "The Division's philosophy has always been that, wherever possible, we will tilt our program in favor of finding ways to make companies eligible for our program rather than looking for ways to keep them out. We maximize the opportunities for companies to report conduct, and we are extremely adverse to practices that may create disincentives. As a result, the U.S. private antitrust bar has confidence that they can accurately advise clients as to whether they are likely to qualify for amnesty under our program. If companies cannot confidently predict how an enforcement authority will apply its leniency program, it may ultimately decide against self reporting and cooperation, and existing cartels may go unreported and unpunished. Our experience has been if you abide by this philosophy and your leniency program rests on a foundation of severe sanctions, high detection rates, and transparent enforcement policies, then cartel members will come knocking on your door." Tradução livre: "A filosofia da Divisão sempre seguiu no sentido de que, quando possível, inclinaremos nosso programa a favorecer a busca de caminhos que tornem as empresas elegíveis para o nosso programa e não a procura de caminhos para mantê-las fora dele. Nós maximizamos as oportunidades para as empresas reportarem condutas e somos extremamente contrários a práticas que possam criar desincentivos. Como resultado, a instituição antitruste privada norte-americana tem confiança em que é possível cuidadosamente aconselhar clientes quanto ao fato de que eles são suscetíveis à qualificação para anistia sob o nosso programa. Se as empresas não podem prever com segurança como uma autoridade aplicará seu programa de leniência, elas podem, ao final, decidir por não relatar sua conduta ou não cooperar e cartéis existentes podem não ser delatados ou restar impunes. Nossa experiência tem demonstrado que se você adotar esta filosofia e seu programa de leniência repousar sobre uma base de sanções severas, altas taxas de detecção e políticas de transparência, então, membros de cartel virão bater em sua porta." (HAMMOND, Scott D. Cornerstones of an effective leniency program).
} 
tornando cada vez mais efetivo o combate às condutas cartelizadoras no País. ${ }^{454}$

Aliás, é natural que os proponentes exijam, em troca das valiosas informações que detêm, a mais profunda certeza e inquestionável transparência acerca dos requisitos estabelecidos e dos benefícios trazidos pelo acordo. Afinal, haverá uma espontânea confissão por parte do candidato seguida de uma desonrosa traição. A demonstrar a importância da objetividade e da transparência para o Programa de Leniência, JULIANA GIRARDELLI VILELA relata que

\begin{abstract}
“[...] a Divisão Antitruste dos Estados Unidos da América considera que deve haver transparência sobretudo nos seguintes aspectos: (i) critérios transparentes para iniciar as investigações; (ii) critérios transparentes para decidir se deve ser apresentada acusação criminal; (iii) transparência no processo; (iv) transparência na negociação do acordo; (v) transparência na aplicação das sentenças e no cálculo das multas; (vi) transparência na aplicação do programa de leniência." ${ }^{455}$
\end{abstract}

Cumpre lembrar que os Estados Unidos da América são considerados pioneiros no Programa de Leniência em termos de regulamentação e, principalmente, de resultados para o combate às condutas anticoncorrenciais. Para eles, a prioridade no Programa sempre foi a objetividade e transparência.

Por outro lado, a par das críticas tecidas, é basilar reconhecer as conquistas do nosso Programa de Leniência. Tendo em vista que um dos principais problemas apontados ao início do Programa recaía na discricionariedade e subjetivismo dos termos do acordo, a Secretaria de Direito Econômico elaborou, em 2008, uma Cartilha sobre combate a cartéis e programa de leniência, com diretrizes a respeito do Programa de Leniência para o público em geral. Os termos e expressões legais são abordados de maneira a auxiliar na compreensão do Programa e a oferecer maiores garantias ao candidato à leniência.

\footnotetext{
454 Consoante o artigo 59, da Portaria do Ministério da Justiça no 456/2010, dentre os objetivos do Programa de Leniência estão "detectar, investigar e punir infrações contra a ordem econômica, notadamente aquelas previstas nos artigos 20 e 21, I, II, III, IV, VIII, ambos da Lei n 8.884, de 11 de junho de 1994" e "assistir, apoiar, orientar e incentivar os proponentes à celebração de Acordo de Leniência".

${ }^{455}$ VILELA, Juliana Girardelli. Aspectos relevantes do Programa de Leniência. P. 206.
} 
Conforme demonstrado ao longo desse capítulo, referida Cartilha não eliminou o grau de subjetivismo e discricionariedade dos termos legais em que posto o acordo de leniência, todavia, relativizou sua intensidade. É de se reconhecer que o documento esclareceu algumas questões dos proponentes que anteriormente sequer eram abordadas. Contudo, está longe do ideal.

\subsubsection{Ministério Público como interventor no acordo}

Em seu artigo 35-C, parágrafo único, a Lei no 8.884/94 prevê que “[...] cumprido o acordo de leniência pelo agente, extingue-se automaticamente a punibilidade dos crimes a que se refere o caput deste artigo." Isto significa que cumpridos os requisitos e condições exigidos pela Secretaria de Direito Econômico, o leniente não mais estará sujeito a uma punição na esfera penal, havendo óbice legal para tanto. A Lei de Defesa da Concorrência estabeleceu como um dos benefícios pela cooperação no acordo a imunidade plena no âmbito penal.

Desta forma, o legislador ordinário criou, fora do Diploma Penal, nova causa extintiva da punibilidade que impossibilita o titular da ação penal nesses delitos, qual seja, o Ministério Público, ${ }^{456}$ de ingressar com a devida demanda ante a confissão documentada do leniente.

$\mathrm{Na}$ linha do quanto exposto anteriormente, referido dispositivo não transmite certeza alguma ou segurança com relação à consequência penal derivada do acordo ao candidato à leniência, na medida em que o instrumento é firmado na esfera administrativa, prevendo implicações diretas - e, em tese, automáticas - no âmbito judicial. ${ }^{457}$

\footnotetext{
${ }^{456}$ Os crimes contra a ordem econômica são de ação penal pública incondicionada.

${ }^{457}$ O Relatório de Sugestões de Aperfeiçoamento do Programa de Leniência Brasileiro elaborado em agosto de 2008 por um Grupo de Trabalho para Discussão sobre o Programa de Leniência da SDE por iniciativa da Diretoria do IBRAC aponta algumas questões que revelam a incerteza inerente ao instituto:

“- a primeira questão está no fato de que a Constituição brasileira outorgou poderes ao Ministério Público para persecução criminal de cartéis e, portanto, pelo critério de resolução de conflito de normas pela hierarquia, tem-se que o MP não estaria vinculado pela lei ordinária;

- ainda, por se tratar o crime de cartel hipótese de ação penal pública incondicionada, não haveria espaço ao juízo de discricionariedade do MP para decidir não oferecer a ação penal diante do conhecimento da infração, seja em obediência ao princípio da indisponibilidade da ação penal, seja para escapar da hipótese de crime de prevaricação;

- outro risco que se aponta decorre do fato de a SDE agir em nome da União, e portanto, vincular tão somente o Ministério Público Federal, e não o Estadual;
} 
E como é cediço, as esferas administrativa e judiciária são claramente distintas, de modo que possuem competências diversas e, por conseguinte, finalidades, estruturação e regulamentação diferenciadas. Inclusive, é tese muito defendida e difundida ${ }^{458}$ a independência entre as instâncias administrativa e judiciária, mesmo quando a decisão de uma autoridade interfere diretamente na cognição da outra. ${ }^{459}$

Em vista disso, a ausência de previsão da participação do titular da medida judiciária, isto é, da ação penal, durante a celebração do acordo de leniência apresenta demasiada insegurança jurídica para aquele que confessará toda a sua participação, assim como de todos os demais membros do cartel, em uma conduta delituosa, trazendo toda e qualquer prova de que disponha para as autoridades. ${ }^{460,}{ }^{461}$ A questão tanto não é pacífica que TAís CARVALHO expõe três diferentes posições que se formaram acerca do tema:

- ainda que um representante do MP (seja Estadual seja Federal) figure como anuente do acordo de leniência, estariam outros membros do Parquet vinculados a referida decisão? Seria o princípio do juiz natural, aplicado pela SDE, por analogia, ao promotor, como 'princípio do promotor natural', suficiente a elidir que membros do MP (lato sensu) ofereçam denúncia diante do conhecimento de fato já acobertado por acordo de leniência? O que se verifica na prática é a promoção de uma ação criminal por parte do representante do MP signatário do Acordo de Leniência, de forma que se torne prevento e exclua a possibilidade dos demais membros deste órgão de proporem ação criminal. Posteriormente à prevenção, a ação criminal é arquivada; $e$

- outro ponto seria o de que o CADE é o responsável por decidir pela extinção da punibilidade em matéria criminal, situação que não se conforma com a previsão constitucional de que é privativo ao Poder Judiciário decidir sobre questões criminais."

${ }^{458}$ Embora se discorde.

${ }^{459}$ Apenas a título de exemplo, cite-se decisão do Supremo Tribunal Federal a respeito da independência das esferas administrativa e penal ao se tratar de Sistema Financeiro (HC 97.567, Rel. Min. Ellen Gracie, Segunda Turma, DJ 27.04.10). No mesmo sentido: $\mathrm{HC} \mathrm{n}^{\circ} 88.759, \mathrm{HC}^{\circ} 88.730, \mathrm{HC}^{\circ} 85.953, \mathrm{AI}^{\circ}$ 521.569 , dentre inúmeros outros. Vale lembrar, contudo, que em determinados casos os tribunais têm reconhecido uma relativa dependência entre as esferas administrativa e judicial. Na área penal tributária, a exemplo, a jurisprudência consolidada sobre o tema exige a constituição definitiva do débito tributário (no âmbito administrativo tributário) para a instauração de uma persecução penal por crimes tributários. As justificativas são variadas: falta de condição de procedibilidade ou de punibilidade, existência de questão prejudicial ou ausência de um dos elementos do tipo penal. Nesse sentido, firme é o entendimento do Supremo Tribunal Federal: $\mathrm{HC}^{\circ}{ }^{\circ}$ 96.055, Rel. Min. Dias Toffoli, Primeira Turma, j. em 06.04.2010; $\mathrm{HC}^{\circ}{ }^{\circ}$ 97.118, Rel. Min. Ricardo Lewandowski, Primeira Turma, j. 23.03.10; $\mathrm{HC} \mathrm{n}^{\circ}$ 91.725, Rel. Min. Eros Grau, Segunda Turma, j. em 10.11.09. (dentre outros julgados mais antigos ADI $\mathrm{n}^{\circ} 1571, \mathrm{HC} \mathrm{n}^{\circ}$ 84.423, $\mathrm{HC} \mathrm{n}^{\circ}$ 85.207, $\mathrm{HC} \mathrm{n}^{\circ} 81.611, \mathrm{HC}^{\circ}$ 85.949, $\mathrm{HC} \mathrm{n}^{\circ}$ 89.983). Não à toa, em dezembro de 2009, foi promulgada a seguinte súmula vinculante sobre o assunto: "Não se tipifica crime material contra a ordem tributária, previsto no art. $1^{\circ}$, incisos I a IV, da Lei $n^{\circ} 8.137 / 90$, antes do lançamento definitivo do tributo." (Súmula Vinculante $\mathrm{n}^{\circ}$ 24).

${ }^{460}$ PEDRo HENRIQUe CARNEIRO DA FonSECA afirma que "com relação ao Acordo de Leniência, nem a Lei Antitruste nem a Portaria $n^{o} 4$ do Ministério da Justiça que trata do Programa de Leniência prevêem a participação do Ministério Público no procedimento do acordo de leniência. Isto se deve porque o instituto foi transplantado para o nosso ordenamento jurídico sem as devidas adaptações, haja vista serem os crimes contra a ordem econômica, com especial atenção à formação de cartéis, classificados como infrações penais e administrativas." (FONSECA, Pedro Henrique Carneiro da. O Ministério Público e o acordo de leniência. Pp. 06/07)

${ }^{461}$ Expondo posicionamento contrário, PAOLO ZUPO MAZZUCATO assevera: "Não procede tal crítica, pois não há usurpação de quaisquer das funçães institucionais constitucionalmente conferidas ao Ministério 
“(a) a norma atribuiria à SDE a faculdade de firmar o programa de leniência, e este acordo, na esfera administrativa, impede que o Ministério Público ingresse com a ação criminal; (b) nega total aplicabilidade das regras do Acordo de Leniência na esfera penal e tem como fundamento o Princípio da Indisponibilidade da Ação Penal Pública; e (c) o consentimento do MP é imprescindível para a realização do Acordo e para decretação da extinção da punibilidade." 462 (grifos da autora)

Ora, o óbice previsto na Lei de Defesa da Concorrência não parece mesmo vincular o membro do Ministério Público a uma decisão administrativa. Isto porque, diante do princípio da obrigatoriedade (ou indisponibilidade da ação penal pública), o Parquet não detém disponibilidade sobre seu poder de mover a ação penal (artigos 28, 42 e 572 do Código de Processo Penal). ${ }^{463}$

É bem verdade que, com o passar dos anos, referido princípio tem sido atenuado pela doutrina e pela jurisprudência, ainda que esteja há tempos arraigado em nosso sistema jurídico. Em obediência à supremacia do direito de liberdade, às exigências da sociedade moderna e à necessidade de distribuição célere da justiça penal, esse princípio vem sendo paulatinamente mitigado.

Público. A Lei 10.149/2000, que introduziu o art. 35-C na Lei Antitruste, não lhe retirou a competência privativa de promoção da ação penal pública; ela tão-somente declarou que a celebração do acordo de leniência impedirá o oferecimento de denúncia e que o cumprimento daquele extinguirá a punibilidade. A CF/1988 conferiu ao Ministério Público a titularidade da ação penal pública (segundo a qual apenas ele, $e$ mais ninguém, poderia apresentar denúncia); mas esta, conforme ainda a Constituição, é exercida segundo a lei.

Tais disposições devem ser interpretadas de forma sistêmica, em conformidade com o art. 395, II, do CPP (cuja constitucionalidade não é alvo de questionamentos). Este declara que a denúncia será rejeitada quando faltar condição para o exercício da ação penal; ora, a determinação do art. 35-C da Lei Antitruste equivale a dizer que a denúncia poderá ser oferecida caso preenchido o requisito de não ter havido celebração de acordo de leniência.

Ademais, oportuna a menção determinada no art. 397, IV, do CPP que, se já estiver extinta a punibilidade (o que ocorre caso o acordo de leniência seja cumprido), o juiz deverá absolver sumariamente o acusado." (Acordo de leniência: questões controversas sobre o art. 35-C da lei antitruste. Pp. 189/190).

${ }^{462}$ CARVALHO, TAÍS. O direito da concorrência e as suas relações com o direito penal.

Posicionamento absolutamente contrário à validade do acordo de leniência, em razão da inobservância aos princípios da obrigatoriedade e da indisponibilidade, é adotado por RAFAEL JUNIOR SOARES. (Da impossibilidade do uso do acordo de leniência como forma de impedir o oferecimento de denúncia pelo Ministério Público).

${ }^{463}$ Segundo CALAMANDREI, não se admite que o Ministério Público, identificando uma hipótese na qual a lei exija sua atuação, se recuse a agir. (Istituzioni di diritto processuale civile. § 126). Para FREDERICO MARQUES, "Esse princípio, profundamente ligado ao da legalidade, domina toda ação pública tendente a obter a atuação da lei penal. Isso significa que a sua missão fundamental é obrigatória e não pode depender de critérios de oportunidade, 'o que não impede a liberdade de juízo do Ministério Público sobre o fundamento da ação'.” (Elementos de direito processual penal. Vol. I. P. 46). 


\title{
Para JosÉ Frederico MARQUES,
}

\begin{abstract}
"Muito embora defenda-se sempre a vigência do princípio da obrigatoriedade da ação penal no direito brasileiro, é preciso admitir a lógica e o bom senso dessa argumentação, para se reconhecer assim, que o postulado dominante no processo penal pátrio é o da obrigatoriedade mitigada ou relativa da propositura da ação penal pública. Se o exame da aplicação, hic et nunc, da lei penal levar à conclusão de que o interesse geral será mais bem resguardado sem a persecução penal acusatória, a ação penal pode deixar de ser proposta." 464
\end{abstract}

É o que se denomina princípio da obrigatoriedade relativa ou mitigada com base no qual o Ministério Público pode não oferecer denúncia por razões de conveniência e oportunidade. Este passa a ser um poder discricionário deste órgão, a ser controlado pelo Poder Judiciário. ${ }^{465}$

Ainda assim, não há uma certeza por parte do leniente de que não sofrerá nenhuma consequência no âmbito penal. Somente a presença do titular da ação penal e sua assinatura aposta no instrumento firmado trarão a tranquilidade merecida ao candidato e à tão prometida leniência. ${ }^{466}$

\footnotetext{
${ }^{464}$ MARQUES, José Frederico. Estudos de direito processual penal. Pp. 100/101.

${ }^{465}$ PEDRo HenRIQUe CARNEIRo FonSECA, por sua vez, entende que não é caso de mitigação do princípio da indisponibilidade: "Destarte, ao verificar a infração e a celebração do acordo de leniência, se for crime contra a ordem econômica disposto na Lei 8.137/90, o 'parquet' está impedido de denunciar nos termos do artigo 35-C, da Lei Antitruste conjugado com o artigo 43, inciso III, do CPP. Isto porque o instrumento de acusação será rejeitado quando faltar condição exigida pela lei para o exercício da ação penal. E desse modo, é exigência da Lei Antitruste seja o 'parquet' impedido de oferecer denúncia na presente situação. A denúncia somente poderá ser oferecida caso não tenha ocorrido celebração do Acordo de Leniência.

Não há que se falar em mitigação do princípio da indisponibilidade já que a ordem de não oferecer a denúncia vem da própria lei. Não é abrandamento do princípio supracitado tendo em vista a celebração de o acordo ser realizada sem a presença do Ministério Público. $O$ ordenamento antitruste não colocou o 'parquet' como personagem provedor da ação penal contra aquele denunciante que celebra o acordo premial na seara administrativa." (FONSECA, Pedro Henrique Carneiro. O Ministério Público e o acordo de leniência. P. 08).

${ }^{466} \mathrm{Na}$ mesma linha, GUILHERME RODRIGUES ABRÃo conclui: "E, ao que parece ser a posição mais adequada às próprias finalidades do instituto ora trabalhado, deverá o Ministério Público ser consultado ao se celebrar o acordo de leniência penal a fim de que com sua anuência seja posteriormente decretada a extinção da punibilidade do agente infrator. Assim, o Ministério Público ao participar da celebração do acordo de leniência dará mais suporte ao mesmo, bem como resultará de plano em renúncia à ação penal, sem maiores divergências futuras. Por certo que diante de tal situação haverá nítida mitigação do princípio da obrigatoriedade da ação penal, mas que em tais casos (repressão à formação de cartéis) se apresenta como medida de extrema razoabilidade." (ABRÃO, Guilherme Rodrigues. O acordo de leniência no direito penal.).
} 
LEONARdo SiCA vai além da exigência da participação do Ministério Público no acordo, prevendo, inclusive, a necessidade de homologação judicial do instrumento firmado para sua plena validade e eficácia:

\begin{abstract}
"O acordo celebrado e cumprido perante a SDE, pela letra da lei, impediria a ação das agências judiciais incumbidas de acionar a justiça penal, como a Polícia Judiciária e, mais especialmente, o Ministério Público. Nesse ponto, entendo que é necessário um reparo: o acordo de leniência, para resultar em efetiva extinção da punibilidade, precisa ser homologado judicialmente e sua celebração, por segurança jurídica, deve ser acompanhada por representante do Ministério Público. Do contrário, como vincular a atuação do Ministério Público ou do Judiciário ao acordo de leniência?

Pela estrutura do direito e processo penal brasileiro, não há nada que obrigue a justiça penal a reconhecer como causa extintiva de punibilidade um acordo celebrado entre autor de crime e o Poder Executivo (a rigor, isso afetaria até a separação tripartida dos poderes). Por outro lado, o cidadão que se submete ao acordo de leniência tem o preceito legal lhe garantindo a extinção, o que, no mínimo, gera a expectativa legítima de usufruir do benefício.

É totalmente razoável - e legal - a hipótese de, mesmo cumprido o acordo, o Ministério Público entender pela propositura da ação penal. Para remediar essa situação de insegurança, parece que a solução seria a participação do Parquet na elaboração do acordo (o que, por outro lado, também é problemático, pois a confissão de um crime perante um órgão acusador pode ser mais difícil)." 467
\end{abstract}

Isto significa que não basta a participação do titular da ação penal para evitar futura propositura da ação cabível, mas é necessária a homologação de um juiz para que o acordo possa de fato produzir efeitos na esfera judicial. Como toda causa extintiva da punibilidade, o acordo de leniência cumprido deverá passar sob o crivo do Poder Judiciário para que haja segurança jurídica quanto à situação do leniente.

\footnotetext{
${ }^{467}$ SICA, Leonardo. Tutela penal da ordem econômica no Direito brasileiro: comparação entre as Leis n. ${ }^{\circ}$ s 8.137/90 e 8.884/94. In: PEREIRA, Flávia Rahal Bresser; VILARDI, Celso; DIAS NETO, Theodomiro (coords.). Análise contemporânea. P. 170.
} 
Ainda assim, urge ressaltar que, mesmo com a participação de algum membro do Ministério Público no acordo, a incerteza quanto à extinção da punibilidade do leniente continua a pairar, uma vez que, de acordo com o artigo 127, §1 $1^{\circ}$ da Carta Magna, são princípios institucionais do Ministério Público tanto a unidade e a indivisibilidade quanto a independência funcional. ${ }^{468}$

Ora, de um lado, o Parquet é uno e indivisível, o que significa que "[...] todos os funcionários da instituição, disseminados por juizados e comarcas, constituem um só órgão sob uma só direção [...]” e “[...] todas as pessoas que compõem o Ministério Público podem ser substituídas umas pelas outras [...]", 469 de outro, o órgão ministerial é funcionalmente independente.

JoSÉ AFONSO DA SILVA já apontava os percalços em seguir o princípio da unidade e indivisibilidade em um sistema federativo:

\begin{abstract}
"Realmente, a pretensão da unidade nesse sentido já constava da exposição de motivos da Comissão elaboradora dos estudos e do anteprojeto da antiga Lei Orgânica do MP (Lei Complementar 40/81 e consagrado na atual: Lei 8.625, de 12.2.93), segundo a qual o Ministério Público é, em seus lineamentos básicos, uma só instituição, quer atue no plano federal, junto à justiça comum ou especial, quer no plano dos Estados, Distrito Federal e Territórios. Não é fácil construir uma unidade e indivisibilidade de instituições que se inserem no contexto da organização federativa, de si diversificante.
\end{abstract}

\title{
(...)
}

Não há como se efetivar isso entre os vários Ministérios Públicos. Só é realizável dentro de cada um deles." 470

\footnotetext{
${ }^{468}$ Esses princípios também estão previstos no artigo $1^{\circ}$, parágrafo único da Lei $n^{\circ}$ 8.625/93 (Lei Orgânica Nacional do Ministério Público): “Art. $1^{o}$ (...) Parágrafo único. São princípios institucionais do Ministério Público a unidade, a indivisibilidade e a independência funcional."

${ }^{469}$ E. FlORIAN. Elementos de derecho processal penal, 1934, p. 88; J. ORTOLAN. Eléments de droit pénal, vol. II, 1875, p. 437/438 Apud FREDERICO MARQUES, José. Elementos de direito processual penal. Vol. I. P. 47.

470 SILVA, José Afonso da. Curso de direito constitucional positivo. P. 595. No mesmo sentido, posicionou-se FREDERICO MARQUES: “No Brasil, em virtude da organização federativa, pode-se dizer que há um parquet em cada Estado, além do que constitui o Ministério Público Federal e dos que funcionam junto às jurisdições especiais. Dentro de cada parquet existe a unidade e indivisibilidade que estruturam a instituição como um corpo hierarquizado. De parquet para parquet, há apenas unidade funcional sob a base da lei, pois na aplicação do direito existem laços de coordenação e igualdade.” (MARQUES, José Frederico. Instituições de processo civil. P. 245).
} 
Assim, a dicotomia de princípios unidade e indivisibilidade versus independência funcional não garante, em absoluto, que a participação de um membro do Ministério Público no acordo de leniência impeça outro representante do Parquet de entender que é caso de oferecimento de denúncia, iniciando um processo penal em face do leniente. Somente a homologação judicial solucionaria o problema. Como se não bastasse, a escolha entre a participação de um membro do Parquet federal ou estadual contribui para a incerteza da tão almejada e "automática" extinção da punibilidade do leniente.

Acerca do assunto, assim se manifestou JOÃo GRANDINO RODAS:

"O cumprimento do acordo, por sua vez, leva à extinção total da punibilidade, impedindo que os delatores sejam processados pelos crimes previstos na Lei $8.137 / 90$.

Tal possibilidade é criticada por dois motivos. O primeiro é relacionado com o fato de serem os crimes contra a ordem econômica de ação pública incondicionada, cabendo somente ao Ministério Público, como titular da ação penal, dispor ou restringir a sua aplicação, nos casos previstos em lei. Com o intuito de sanar essa questão, a Secretaria de Direito Econômico passou a incluir como signatários dos acordos de leniência Procuradores da República e Promotores Estaduais, que se tenham comprometido a não proceder à denúncia criminal relativa à conduta sob investigação. Essa inclusão tem fundamental importância como forma de resguardar a empresa de futuros processos no campo penal. Estar-se-ia assim, aproveitando-se no sistema jurídico brasileiro, o princípio da oportunidade e da plea bargaining do direito norte-americano e do pattegiamento do direito italiano." 471

Ao concluir seu trabalho, apontando as fontes de incerteza do acordo de leniência, o autor assevera que

"[...] o afastamento de responsabilidade penal exclusivamente pela SDE ainda é controverso. Para se proteger, a empresa deve se certificar que a autoridade competente do Ministério Público firme igualmente o acordo de leniência,

${ }^{471}$ RODAS, João Grandino. Acordos de leniência em direito concorrencial. P. 29. 
com o fito de se resguardar contra futuras ações no campo penal pela prática delatada." 472

De fato, diante dessas reiteradas críticas, a Secretaria de Direito Econômico declarou expressamente em sua Cartilha a cartéis e programa de leniência que

\begin{abstract}
“[...] ainda que não seja requisito previsto na Lei $n^{\circ} 8.884 / 94$, havendo anuência da parte, a SDE pode convidar o Ministério Público Federal ou Estadual para atuar como interveniente-anuente do acordo. O Ministério Público reconhece o Programa de Leniência como importante pilar no Programa de Combate a Cartéis e é importante destacar que nenhum beneficiário de Acordo de Leniência enfrentou processo criminal pela prática denunciada, o que tem garantido o sucesso do Programa." ${ }^{473}$
\end{abstract}

Como se vê, não foram estabelecidos critérios objetivos para a escolha da participação do Ministério Público Federal ou Estadual. O interveniente-anuente "convidado" pode ser tanto o representante do Parquet federal quanto o estadual - e aqui a insegurança para o leniente fica ainda maior.

Sob a justificativa de que algum membro do Ministério Público firmou o acordo, o candidato pode ter a falsa sensação no sentido de que não poderá ser denunciado; porém, a depender da interpretação acerca da competência para se processar e julgar os crimes de cartel, cai por terra a certeza sobre o óbice legal.

Na tentativa de solucionar o problema, EduARDo Molan Gaban afirmou que "[...] um critério para se determinar qual dos parquets deve participar e assinar o acordo de leniência, a bem de sua plena efetividade em face dos lenientes, é identificar se o caso aproxima-se mais da competência da Justiça Estadual ou da competência da Justiça Federal." ${ }^{474}$ Acontece que a competência para o processamento e julgamento desses crimes não restou bem determinada pela Lei $\mathrm{n}^{\circ}$ 8.137/90, dando margem a diversas interpretações sobre o tema.

\footnotetext{
${ }^{472}$ Idem, ibidem, p. 32.

${ }^{473}$ BRASIL. MINISTÉRIO DA JUSTIÇA. SECRETARIA DE DIREITO ECONÔMICO. Cartilha sobre combate a cartéis e programa de leniência. $P$. 21.

${ }^{474}$ GAB AN, Eduardo Molan. Acordos de leniência no Brasil (Lei n. 8.884/94).
} 
Na verdade, a solução não é assim tão simplória. Como já apontado por LEONARDO SICA,

\begin{abstract}
“[...] há enorme controvérsia jurisprudencial quanto à competência (estadual ou federal) para processar e julgar crimes contra a ordem econômica (ver HC 32.292/RS, do STJ) e, como os Ministérios Públicos Federal e Estadual são independentes entre si, restaria a possibilidade de um acordo ratificado por membro do órgão federal não ser seguido por um promotor estadual que entendesse pela necessidade de ação penal." ${ }^{475}$
\end{abstract}

Um dos primeiros parâmetros utilizados para dirimir a questão foi a Súmula 498 do Supremo Tribunal Federal, que dizia respeito aos crimes da Lei $\mathrm{n}^{\circ} 1.521 / 51$, segundo a qual, "Compete à justiça dos Estados, em ambas as instâncias, o processo e o julgamento dos crimes contra a economia popular." Com base na Súmula, algumas decisões consideraram a Lei $\mathrm{n}^{\circ} 8.137 / 90$ uma sucessora da Lei $\mathrm{n}^{\circ} 1.521 / 51$, optando-se pela competência da Justiça Estadual. ${ }^{476}$ Contudo, esse raciocínio baseou-se em analogia equivocada, não condizente com os diferentes bens jurídicos tutelados e as distintas tipificações das leis mencionadas. ${ }^{477}$

A dificuldade ficou ainda maior quando analisada a competência desses crimes à luz do artigo 109 da Constituição Federal, que define expressamente a competência da Justiça Federal. $^{478}$ De acordo com o referido artigo, resta à Justiça Estadual uma competência subsidiária, abrangendo as demais hipóteses não taxativamente previstas nesse dispositivo. Em nenhum dos incisos do citado artigo foi prevista a competência federal em relação aos crimes concorrenciais.

Muitas decisões atribuem à Justiça Federal a competência para processamento e julgamento dos crimes de cartel, seja sob o argumento de que nesses crimes há interesse do

\footnotetext{
475 SICA, Leonardo. Op. cit., pp. 170/171.

476 A exemplo, Recurso Criminal nº 960460365-5, Rel. Juíza Tânia Escobar, DJ 12.03.1997, do Tribunal Regional Federal da $4^{\mathrm{a}}$ Região.

${ }^{477}$ Cf. GAMEIRO, João Augusto Prado da Silveira. Op. cit., p. 217.

478 “[...] Art. 109. Aos juízes federais compete processar e julgar: I - as causas em que a União, entidade autárquica ou empresa pública federal forem interessadas na condição de autoras, rés, assistentes ou oponentes, exceto as de falência, as de acidentes de trabalho e as sujeitas à Justiça Eleitoral e à Justiça do Trabalho; (...) IV - os crimes políticos e as infrações penais praticadas em detrimento de bens, serviços ou interesse da União ou de suas entidades autárquicas ou empresas públicas, excluídas as contravenções e ressalvada a competência da Justiça Militar e da Justiça Eleitoral; (...) VI - os crimes contra a organização do trabalho e, nos casos determinados por lei, contra o sistema financeiro e a ordem econômico-financeira."
} 
CADE (autarquia federal) ou dos órgãos pertencentes ao Sistema Brasileiro de Defesa da Concorrência em geral, todos situados na estrutura da Administração Federal, seja recorrendo-se à natureza dos crimes econômicos. ${ }^{479}$ Deve-se atentar que o fato de os órgãos administrativos de regulação da concorrência fazerem parte da Administração Federal não implica que os crimes dessa natureza devem ser submetidos à Justiça Federal. $^{480}$

A expressão "crimes contra os interesses da União", em que pese servir de justificativa para a competência federal dos crimes de cartel, não deve ser considerada por si só para tanto, pois qualquer delito praticado na sociedade afeta o Estado.

O inciso VI do artigo 109 da Carta Magna é fundamento para a fixação da competência federal desses crimes, mas faz a importante ressalva de que os crimes contra a ordem econômico-financeira serão processados pela Justiça Federal nos casos determinados por lei, o que não ocorreu na Lei $n^{\circ} 8.137 / 90$. Dessa forma, ante a ausência expressa de previsão legal, a competência para processamento e julgamento dos ilícitos penais contra a ordem econômica deveria ser da Justiça Estadual.

Diante da inconsistência desses argumentos para fixar a competência federal, inúmeros acórdãos passaram a reconhecer a competência da Justiça Estadual para processar e julgar os crimes de cartel, ${ }^{481}$ sendo esse o posicionamento majoritário atual. ${ }^{482}$

\footnotetext{
${ }^{479} \mathrm{Em}$ defesa da competência federal, cf. MAIA, Rodolfo Tigre. A tutela da ordem econômica na Lei $\mathbf{n}^{\mathbf{0}}$ 8.137/90. Pp. 247/248.

${ }^{480}$ Exemplo disso é o caso do Departamento de Proteção e Defesa do Consumidor, que, embora seja órgão vinculado ao Ministério da Justiça, não implica na competência federal dos crimes contra o consumidor.

${ }^{481}$ Os argumentos utilizados são os seguintes: (i) não existe previsão expressa em lei indicando a competência federal para os crimes contra a ordem econômica (STJ, CC 42957, Rel. Min. Laurita Vaz, Terceira Seção, DJ 02.08.2004); (ii) tem-se a impossibilidade de se adotar uma interpretação extensiva ao texto constitucional ampliando as hipóteses de competência criminal da Justiça Federal (STJ, CC 40165, Rel. Min. José Arnaldo da Fonseca, Terceira Seção, DJ 02.02.04); (iii) o fato de os órgãos administrativos responsáveis pela regulação da concorrência se encontrarem na estrutura da Administração Federal não implica diretamente na competência federal para julgamento de crimes concorrenciais (TRF $3^{\text {a }}$ Região, HC 200103000357690, Rel. Des. Fed. André Nekatschalow, Quinta Turma, DJ 01.06.04); (iv) não há ofensa direta a bens, serviços ou interesses de entidades federais nos crimes contra a ordem econômica (STJ, CC 15.206, Rel. Min Fernando Gonçalves, Terceira Seção, DJ 23.06.1997); (v) nos crimes previstos no artigo $4^{\circ}$ da Lei ${ }^{\circ}$ 8.137/90, não se verifica um dano concreto à Federação (STJ, CC 37.226, Rel. Min. Jorge Scartezzini, Terceira Seção, DJ 01.07.04).

${ }_{482}$ Em defesa da competência estadual, seguem as recentes decisões do Superior Tribunal de Justiça: AgRg 166909/RS, Rel. Min. Haroldo Rodrigues, Sexta Turma, DJ 08.06.11 e CC 56.193, Rel. Min. Og Fernandes, Sexta Turma, DJ 05.03.09. Também o Supremo Tribunal Federal, ao tratar de crimes contra a ordem econômica (incluídos os delitos previstos na Lei $\mathrm{n}^{\circ}$ 8.176/90), manifestou-se pela competência da Justiça Estadual: RE no 454737, Rel. Min. Cezar Peluso, Tribunal Pleno, DJ 16.12.08; RE nº 513444, Rel. Min. Dias Toffoli, DJ 24.09.10, RE nº 451488, Rel. Min. Marco Aurélio, DJ 20/05/11.
} 
A par desses dois entendimentos opostos, o Superior Tribunal de Justiça apresentou um terceiro posicionamento - seguido por alguns tribunais -, atribuindo ao processamento e julgamento dos crimes de cartel a competência federal ou estadual, a depender do caso concreto. Com efeito, a competência federal seria justificada na medida em que restasse comprovado o reflexo do cartel em vários estados-membros, caracterizando um interesse suprarregional, tornando-se premente a interferência da União. ${ }^{483}$ Ainda que válido o argumento, a aplicação deste posicionamento nos casos concretos resta prejudicada, tendo em vista a fluidez da expressão interesse suprarregional e a dificuldade de se determinarem os exatos reflexos em diversos estados-membros. ${ }^{484}$

A Lei $n^{\circ} 10.446 / 2002$ utiliza o critério dos efeitos suprarregionais do cartel para fixação da competência quando prevê que a Polícia Federal pode investigar esses crimes quando houver repercussão interestadual ou internacional, sem prejuízo da responsabilidade de outros órgãos de segurança pública. ${ }^{485}$

A dificultar ainda mais a compreensão e definição da questão, foi aprovado recentemente pelo Congresso Nacional o Projeto de Lei $n^{\circ} 3.937 / 2004,{ }^{486}$ que incluía o artigo 16-A à Lei no $8.137 / 90$ com a seguinte redação: “Compete à Justiça Federal processar e julgar os crimes contra a ordem econômica previstos no caput e nos arts. $5^{\circ} e$ $6^{\circ}$ desta Lei." (artigo 120)

Ocorre que tal Projeto de Lei apresentou imensa contradição em seus termos. Se, por um lado, estabelecia a competência tão somente para o processamento e julgamento

483 Cf. STJ, HC 117169, Rel. Min. Napoleão Nunes Maia Filho, Quinta Turma, DJ 16.03.09; STJ, HC 32.292, Rel. Min. José Arnaldo da Fonseca, Quinta Turma, DJ 03.05.04; TRF $4^{\text {a }}$ Região HC n 00041892320104040000, Rel. Des. Fed. Tadaaqui Hirose, Sétima Turma, DJ 08.04.2010.

${ }^{484}$ JoÃo AUgusto PRADO DA SILVEIRA GAMEIRO explica que "[...] isso se dá pelo fato de a economia moderna ser caracterizada pela existência de mercados complexos, na qual as atividades das mais distintas estão intimamente relacionadas e são financiadas por investimentos dinâmicos que trocam rapidamente de mãos. Certo é que, no âmbito administrativo, é possível a definição de mercado relevante identificado, causando, na verdade, prejuízos a toda a economia nacional, guardando potencial para atingir até mesmo indivíduos e economias estrangeiros. O recurso à delimitação dos prejuízos, portanto, poderia levar à uma cadeia infindável, que resultaria, sempre, na fixação da competência federal.” (Op. cit., p. 222).

485 "Art. $1^{o} \mathrm{Na}$ forma do inciso I do $\$ 10$ do art. 144 da Constituição, quando houver repercussão interestadual ou internacional que exija repressão uniforme, poderá o Departamento de Polícia Federal do Ministério da Justiça, sem prejuízo da responsabilidade dos órgãos de segurança pública arrolados no art. 144 da Constituição Federal, em especial das Polícias Militares e Civis dos Estados, proceder à investigação, dentre outras, das seguintes infrações penais (...) II - formação de cartel (incisos I, a, II, III e VII do art. 4o da Lei no 8.137, de 27 de dezembro de 1990); [...]".

${ }^{486}$ No Senado Federal, este Projeto de Lei é o de $n^{\circ}$ 06/2009. 
dos delitos previstos nos artigos $5^{\circ}$ e $6^{\circ}$ da Lei $n^{\circ} 8.137 / 90,{ }^{487}$ por outro determinava a revogação destes mesmos dispositivos legais (artigo 127).

Felizmente, ao sancionar referido projeto transformando-o na Lei ${ }^{\circ} 12.529 / 11$, a presidenta da República acolheu manifestação do Ministério da Justiça e da AdvocaciaGeral da União no sentido de vetar o artigo $120 .{ }^{488}$

Assim, ainda que tenha sido acenada a vontade do legislador de determinar expressamente em lei a competência federal dos crimes contra a ordem econômica constantes na Lei no 8.137/90, o tema permanece sem regulamentação legal.

Note-se que a questão da competência para processamento e julgamento dos crimes de cartel é inegavelmente controversa, de maneira que não se pode escolher, ao talante da Secretaria de Direito Econômico, qual órgão do Ministério Público, seja ele federal, seja estadual, firmará o acordo de leniência como interventor.

Para que se alcance a segurança jurídica pretendida para o leniente, incentivando-o a colaborar efetivamente com as autoridades antitruste, apresentando provas e indicando todos os envolvidos na prática delituosa, mister se faz a participação de representante do Parquet federal e do Parquet estadual em todos os acordos celebrados.

Em que pese essa imprescindível modificação no Programa de Leniência, vale asseverar que o assunto já foi abordado perante o Poder Legislativo. Em 2006, foi elaborada uma sugestão de Projeto de Lei (SUG n ${ }^{\circ}$ 228/2006) pela Comissão de Legislação Participativa perante a Câmara dos Deputados, prevendo o que segue:

\footnotetext{
“O Ministério Público deverá participar nos acordos em que a Administração Pública realizar com particulares que repercutirem efeitos na área criminal, notadamente no acordo de leniência feito pelo CADE, e nos de natureza tributária feitos pela administração fazendária."
}

Entretanto, no final de 2007, a sugestão foi rejeitada por unanimidade.

\footnotetext{
${ }^{487} \mathrm{O}$ dispositivo menciona também o delito previsto no caput, mas inexiste descrição típica no caput do artigo 16-A.

${ }^{488}$ As razões do veto foram assim apresentadas: "O dispositivo faz referência aos arts. $5^{\circ}$ e $6^{\circ}$ da Lei $n^{o}$ 8.137, de 1990, que, no entanto, estão sendo expressamente revogados pelo art. 127 do próprio projeto de lei."
} 
É primordial frisar que para atingir a plenitude da segurança jurídica ao candidato e estimular ainda mais a corrida à leniência, não basta a previsão da participação de representantes do Ministério Público Federal e Estadual no âmbito penal. Isto porque, o Ministério Público possui atribuições criminais e funções na seara civil, notadamente para a defesa dos consumidores e da ordem econômica, tais como a promoção de inquéritos civis e de ações civis públicas. ${ }^{489}$

No Estado de São Paulo, inclusive, foi criada a Procuradoria de Justiça de Interesses Difusos e Coletivos

\begin{abstract}
“[...] com atribuição para oficiar nas ações civis públicas, ações populares e respectivos incidentes, ações cautelares e respectivos incidentes, mandados de segurança individuais ou coletivos e mandados de injunção coletivos, que envolvam interesses metaindividuais, em trâmite no Tribunal de Justiça de São Paulo." ${ }^{490}$
\end{abstract}

Diante da celebração de um acordo de leniência, o promotor de justiça ou procurador da República que firmar o instrumento como interveniente-anuente deixará de promover a competente ação penal, em observância à proibição legal, mas poderá comunicar de pronto outro representante do Ministério Público para instaurar inquérito civil ou mesmo ingressar diretamente com uma ação civil pública em face do leniente, eis que municiado com a sua própria confissão.

Diante disso, ao firmar o acordo, o leniente estaria, na prática, aceitando a instauração de uma ação contra si e, o que é bastante temerário, fornecendo à parte autora provas que possivelmente levem à sua condenação.

\footnotetext{
489 “[...] Art. 25. Além das funções previstas nas Constituições Federal e Estadual, na Lei Orgânica e em outras leis, incumbe, ainda, ao Ministério Público:

IV - promover o inquérito civil e a ação civil pública, na forma da lei:

a) para a proteção, prevenção e reparação dos danos causados ao meio ambiente, ao consumidor, aos bens e direitos de valor artístico, estético, histórico, turístico e paisagístico, e a outros interesses difusos, coletivos e individuais indisponíveis e homogêneos;" (Lei no 8.625/93, Lei Orgânica Nacional do Ministério Público).

Cumpre registrar que, de acordo com o artigo $1^{\circ}$ da Lei no 7.347/85 (Lei da Ação Civil Pública), a ação civil pública é cabível quando houver dano moral ou patrimonial causado ao consumidor, a qualquer outro interesse difuso ou coletivo, por infração da ordem econômica e da economia popular, dentre outros.
490 Procuradoria de Justiça de Interesses Difusos e Coletivos. (Disponível em: <http://www.mp.sp.gov.br/portal/page/portal/procuradoria_interesses_difusos_coletivos>. Acesso em 18 de julho de 2011).
} 
É bem verdade que a Lei de Defesa da Concorrência não prevê a imunidade civil para o leniente. Porém, é inegável que a previsão da participação de um representante do Ministério Público cível traz maior segurança ao agente econômico envolvido na prática de condutas anticoncorrenciais. O tratamento mais brando em todas as esferas estimulará um número maior de candidatos, e de maneira ainda mais célere, a trair o ajuste e cooperar plenamente com as autoridades antitruste.

\subsubsection{Decisão do Conselho Administrativo de Defesa Econômica e a reserva de jurisdição}

Depreende-se dos preceitos legais que os efeitos penais decorrentes do instituto da leniência serão declarados pelas autoridades administrativas antitruste. Isto porque, de acordo com a Lei de Defesa de Concorrência, a celebração do acordo de leniência implicará na suspensão do curso do prazo prescricional e impedirá o oferecimento da denúncia, assim como o seu cumprimento levará à extinção automática da punibilidade dos crimes contra a ordem econômica previstos na Lei $\mathrm{n}^{\circ} 8.137 / 90$.

Não há previsão alguma de participação do Poder Judiciário na celebração do acordo, seja mediante uma análise prévia de seus termos por um magistrado, seja por meio de uma homologação judicial posterior. Pelos ditames legais, a decretação de seus efeitos penais para o leniente não provém de uma decisão judicial.

O legislador, de fato, não pretendeu que o Poder Judiciário tomasse, sequer, conhecimento da suspensão da pretensão punitiva ou da decisão de extinção da punibilidade dos crimes contra a ordem econômica com relação ao leniente. Todo o procedimento do acordo deve ocorrer perante os órgãos administrativos, sob a orientação de autoridades administrativas.

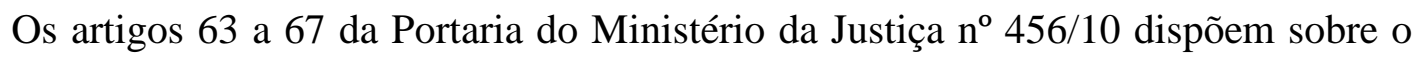
procedimento das propostas de acordo de leniência, indicando que todo o seu trâmite ocorre perante a Secretaria de Direito Econômico. As propostas orais e escritas devem ser formuladas ao chefe de Gabinete da Secretaria de Direito Econômico, sendo este o órgão responsável por estabelecer prazos adicionais para o seu aperfeiçoamento. A esta mesma 
Secretaria é permitido estender a validade das propostas e elaborar requerimentos aos proponentes, dentre tantas outras atribuições.

Igualmente, o artigo 73 do mesmo diploma prevê que o acordo de leniência será "[...] firmado com a União, por intermédio da Secretaria de Direito Econômico [...]" (grifos nossos), de modo que todas as obrigações do signatário do acordo devem ser cumpridas perante este órgão. Já o artigo 75 da Portaria revela que o CADE declarará o cumprimento do acordo de leniência e decretará em favor do signatário do instrumento os seus efeitos administrativos, sendo automática a extinção da punibilidade dos crimes contra a ordem econômica. ${ }^{491}$

Assim, compete ao CADE a análise dos termos do acordo de leniência para posterior declaração de seu cumprimento e de seus efeitos, seja na esfera administrativa, seja na penal, dispensando-se a participação, ou mesmo a ciência, do Poder Judiciário.

Sob a óptica constitucional, a atividade de análise do cumprimento do acordo de leniência e a decisão dela decorrente na ambiência penal não podem ser atribuídas a uma autarquia federal, constituindo função exclusiva do Poder Judiciário. Isto porque, consoante o disposto no artigo $5^{\circ}$, inciso XXXV, da Carta Magna, “[...] a lei não excluirá da apreciação do Poder Judiciário lesão ou ameaça a direito.” É o conhecido princípio da reserva de jurisdição.

O constitucionalista JOSÉ AFONSO DA SILVA assim discorreu acerca desse princípio fundamental:

\footnotetext{
“A jurisdição hoje é monopólio do Poder Judiciário do Estado (art. 5, XXXV). Anteriormente ao período moderno havia jurisdição que não dependia do Estado. Os senhores feudais tinham jurisdição dentro de seu feudo: encontravam-se jurisdições feudais e jurisdições baronais. Lembre-se de que os donatários das Capitanias Hereditárias no Brasil colonial dispunham
}

\footnotetext{
491 “[...] Art. 75. Uma vez declarado o cumprimento do Acordo de Leniência pelo Conselho Administrativo de Defesa Econômica, será decretada em favor do signatário do Acordo de Leniência:

I - A extinção da ação punitiva da administração pública, nas hipóteses em que a proposta do Acordo de Leniência tiver sido apresentada à Secretaria de Direito Econômico sem que essa tivesse conhecimento prévio da infração noticiada; ou

II - Nas demais hipóteses, a redução de um a dois terços das penas aplicáveis na seara administrativa.

Parágrafo único. Nas duas hipóteses referidas acima, extingue-se automaticamente a punibilidade dos crimes tipificados na Lei $n^{\circ}$ 8.137, de 27 de novembro de 1990."
} 
da jurisdição civil e criminal nos territórios de seu domínio. No período monárquico brasileiro, tínhamos a jurisdição eclesiástica, especialmente em matéria de direito de família, a qual desapareceu com a separação entre Igreja e Estado. Agora só existe jurisdição estatal, confiada a certos funcionários, rodeados de certas garantias: os magistrados." ${ }^{492}$ (grifos do autor)

Ao delinear as diferenças entre a jurisdição e a administração, asseverou o autor:

\begin{abstract}
"Mais difícil é estremar a jurisdição da administração. Vários critérios têm sido propostos para estabelecer a distinção. Os processualistas preocupamse com o assunto. Chiovenda, por exemplo, concebe a jurisdição como uma atividade secundária, ou coordenada, no sentido de que ela substitui a vontade ou a inteligência de alguém, cuja atividade seja primária, enquanto o administrador exerce atividade primária, ou originária, no sentido de que a desenvolve no seu próprio interesse. O juiz julga a respeito de outrem e em razão da vontade da lei concernente a outrem. A administração decide a respeito da própria atividade.
\end{abstract}

(...)

Essas idéias são úteis para o constitucionalista, que, no entanto, se satisfaz com o critério orgânico, considerando como de jurisdição aquilo que o legislador constituinte incluiu na competência dos órgãos judiciários e como administração o que conferiu aos órgãos do Executivo, que, em verdade, não se limita à execução da lei, consoante já vimos. Segundo esse critério, ato jurisdicional é o que emana dos órgãos jurisdicionais no exercício de sua competência constitucional respeitante à solução de conflitos de interesses." ${ }^{493}$ (grifos do autor)

Não é válido que uma lei ordinária retire da atribuição do Poder Judiciário a análise de uma questão criminal. Compete somente ao magistrado analisar o teor do acordo de leniência e a possibilidade de ser decretada a extinção da punibilidade dos crimes sob apuração com relação ao leniente. Só que isto não significa um impedimento ao legislador para a criação de novas causas extintivas da punibilidade. Se entender pertinente, lhe é permitido estabelecer, em atendimento às exigências atuais da sociedade, uma nova causa, tal como o cumprimento do acordo de leniência. Todavia, lhe é terminantemente vedado

${ }_{493}^{492}$ SILVA, José Afonso da. Op. cit., p. 552.

${ }^{493}$ Idem, ibidem, pp. 552/553. 
retirar da apreciação do magistrado questão penal de extrema relevância, sob pena de ver declarada a inconstitucionalidade do dispositivo legal.

Ao tratar um paralelo com os crimes tributários, a problemática torna-se ainda mais evidente, eis que notável um amplo respeito à reserva de jurisdição.

Como se sabe, a apuração e decisão final acerca da prática de infrações tributárias são atribuições exclusivas de órgãos administrativos; logo, compete à Receita Federal, à Receita de cada um dos estados-membros e dos municípios e também à Previdência Social a análise acerca de uma eventual supressão de tributos, sonegação de informações às autoridades, omissão de obrigações acessórias, o quantum debeatur a ser pago pelo contribuinte e o lançamento definitivo do débito tributário, dentre outras questões, todas sujeitas ao reexame por órgãos administrativos superiores nos termos da legislação aplicável à espécie.

Mesmo diante dessa exclusiva e especializada competência, os órgãos administrativos tributários saem de cena quando suas decisões esbarram em questões penais, de maneira que os reflexos criminais de suas deliberações são debatidos somente na esfera judicial penal. Exemplo disso é a conhecida representação fiscal para fins penais. Logo após a lavratura de um auto de infração pelo órgão competente ou tão logo constituído o crédito tributário, ${ }^{494}$ as autoridades fiscais devem comunicar ao Ministério Público Estadual ou Federal, a depender do tributo em questão, acerca de uma possível prática de crime. Em que pese seja feita uma análise preliminar sobre a existência de indícios de um delito pelo órgão administrativo, uma investigação ou um processo penal só é instaurado se as autoridades judiciárias julgarem a representação pertinente. Ainda que o fato seja apurado no bojo de um processo penal, a decisão final, condenatória ou absolutória, do Poder Judiciário não é vinculativa à determinação administrativa inicial.

Diante disso, a reserva de jurisdição é preservada quanto aos reflexos penais do parcelamento do tributo e o seu pagamento integral. $O$ atual artigo 83 da Lei $n^{\circ}$

\footnotetext{
${ }^{494} \mathrm{O}$ momento exato em que a representação fiscal para fins penais deve ser encaminhada ao Ministério Público ainda é controverso. No âmbito federal, por exemplo, muito embora o Decreto $\mathrm{n}^{\circ}$ 2.730/1998 e a Portaria RFB $n^{\circ}$ 2.439/2010 apontem a necessidade da constituição definitiva do crédito tributário para que a comunicação possa ser feita (ao menos com relação a crimes contra a ordem tributária), não é o que a prática tem demonstrado.
} 
9.430/96, ${ }^{495}$ recém-alterado pela Lei no $12.382 / 11$, reafirmou posicionamento já adotado pela legislação pátria no sentido de que tais atos realizados no âmbito administrativo produzem efeitos diretos na esfera penal. ${ }^{496}$

Indiscutivelmente, são funções exclusivas dos órgãos administrativos tributários arrecadar os valores devidos pelos contribuintes e, segundo a sua conveniência, permitir o parcelamento dos débitos, estabelecendo, para tanto, regras e procedimentos próprios. Assim, cabe às autoridades fiscais atestar o efetivo pagamento de um tributo ou o preenchimento dos requisitos essenciais para o ingresso em um programa de parcelamento e a sua permanência nele, mas, nem por isso, é de sua competência decretar os reflexos penais dessas decisões.

Ao reverso, as Receitas Federal, Estadual, Municipal ou a Previdência Social limitam-se a informar ao magistrado sobre os atos realizados na sua esfera de atuação, tendo este último de suspender a pretensão punitiva do Estado ou extinguir a punibilidade penal com relação ao contribuinte. ${ }^{497}$

495 “[... A Art. 83. (...) $\S 1^{\circ} \mathrm{Na}$ hipótese de concessão de parcelamento do crédito tributário, a representação fiscal para fins penais somente será encaminhada ao Ministério Público após a exclusão da pessoa física ou jurídica do parcelamento.

$\S 2^{\underline{o}} E$ suspensa a pretensão punitiva do Estado referente aos crimes previstos no caput, durante o período em que a pessoa física ou a pessoa jurídica relacionada com o agente dos aludidos crimes estiver incluída no parcelamento, desde que o pedido de parcelamento tenha sido formalizado antes do recebimento da denúncia criminal.

$\S 3^{\underline{o}}$ A prescrição criminal não corre durante o período de suspensão da pretensão punitiva.

$\S 4^{o}$ Extingue-se a punibilidade dos crimes referidos no caput quando a pessoa física ou a pessoa jurídica relacionada com o agente efetuar o pagamento integral dos débitos oriundos de tributos, inclusive acessórios, que tiverem sido objeto de concessão de parcelamento."

${ }^{496}$ Os dispositivos legais anteriores sobre a matéria são: artigo 34 da Lei no 9.249/95, artigo $9^{\circ}$, $^{\circ}{ }^{\circ}$ da Lei $n^{\circ}$ $10.684 / 03$ e artigo 69 da Lei $n^{\circ} 11.941 / 09$. Ressalte-se que não adentraremos na questão referente ao momento em que o pagamento do tributo deve ser realizado para que a punibilidade seja extinta, em razão de não ser esse o escopo do presente cotejo analítico.

${ }^{497}$ Seguindo esse e outros exemplos similares, RAFAEL JUNIOR SOARES, ao analisar o dispositivo legal que prevê o acordo de leniência, preceitua: "O que fica claro no dispositivo em tela é que o legislador tolheu a função conferida ao Ministério Público, em flagrante inconstitucionalidade, eis que não se pode conferir aos órgãos concorrentes incumbidos da persecução no âmbito administrativo (p. ex. Receita Federal, COAF, SDE etc) a possibilidade de interferência automática no processo penal, em razão do princípio da independência das instâncias, sem que haja participação principalmente do Parquet, ou do Poder Judiciário (artigo $5^{\circ}, X X X V, C F$ ), ainda que por meio da homologação do acordo (tese aventada por alguns doutrinadores, com a qual não se concorda)." (SOARES, Rafael Junior. Da impossibilidade do uso do acordo de leniência como forma de impedir o oferecimento de denúncia pelo Ministério Público). 
Ora, não cabe à Administração Pública, incluídos todos os seus órgãos e entidades autárquicas, decidir sobre os direitos de terceiros decorrentes de lei, mas apenas sobre a sua própria atividade. Aliás, não existe administração penal, e sim jurisdição penal ${ }^{498}$

Por essa razão, José LuIS OliveIRA LIMA e RodRigo DALl’ACQUA sustentam a inconstitucionalidade do instituto da leniência:

\begin{abstract}
“A inconstitucionalidade reside no fato de que são os órgãos administrativos que tomam as mais importantes decisões em matéria criminal, de forma isolada e automática. Analisam as provas apresentadas, definem qual crime foi cometido, ponderam se a identificação dos co-autores foi adequada, e, por fim, extinguem a punibilidade do ilícito penal. A ilegalidade é evidente, pois a SDE e o CADE não integram o Poder Judiciário e, logicamente, não podem julgar questões penais.
\end{abstract}

Permitir que um órgão administrativo julgue um caso criminal implica em grave ofensa ao princípio da reserva de jurisdição, previsto no $\operatorname{artigo} 5^{\circ}$ da nossa Constituição. Este princípio garante o monopólio do Poder Judiciário em decidir determinadas questões, notadamente as criminais. É em razão da reserva de jurisdição, por exemplo, que não se permite que uma lei outorgue poderes ao Ibama, Receita Federal ou Banco Central para decidirem o destino de acusados por crimes ambientais, tributários ou financeiros.

A conseqüência desta inconstitucionalidade certamente não será a subtração dos benefícios penais do agente que, crendo na validade da lei, confessou seu crime e delatou seus co-autores. A repercussão é muito maior, fulminando o acordo como um todo, uma vez que a inexeqüível imunidade penal concedida pelo CADE não é um mero efeito do acordo de leniência, mas sim um de seus mais sólidos alicerces." 499

É interessante notar que a decisão acerca da extinção da punibilidade dos crimes contra a ordem econômica, além de ser proferida por autoridade administrativa incompetente para tanto -, é realizada de forma automática.

\footnotetext{
${ }^{498}$ Segundo JOSÉ FREDERICO MARQUES: "Na jurisdição penal, aplica-se o direito penal objetivo em conexão com uma pretensão punitiva ou com uma pretensão baseada no direito de liberdade penal" (MARQUES, José Frederico. Elementos de Direito Processual Penal. Vol. III. P. 196).

499 OLIVEIRA LIMA, José Luis e DALL'ACQUA, Rodrigo. Ordem econômica. A inconstitucionalidade do acordo de leniência.
} 
No campo penal, em toda a legislação pátria, não há previsão de decisões judiciais automáticas. Pelo contrário, o automatismo é rechaçado, pois toda e qualquer decisão do Poder Judiciário é proferida com cautela, seguindo critérios legais e objetivos, em decorrência de uma detida análise do caso concreto.

$\mathrm{O}$ assunto vem sendo reiteradamente discutido entre os especialistas, conforme informa a seguinte publicação:

"Especialistas (...) sustentam que toda a tramitação dos acordos de leniência, por força de lei, é realizada administrativamente. Nesse aspecto, afirmam, a ausência do Judiciário deveria ser reconsiderada (a SDE diz que há participação da Justiça nos acordos). Afinal, fica a cargo de um órgão público a avaliação de que determinada conduta possa ser considerada ou não uma infração penal.

$(\ldots)$

Rechulski avalia que o Judiciário não poderia ficar à margem da realização destes acordos. 'Não se pode tirar o Judiciário de cena, principalmente, em decisões com reflexos tão importantes, tanto na esfera pessoal como coletiva.' A opinião do advogado criminalista Rodrigo Dall'Acqua vai no mesmo sentido. 'Todo acordo de leniência é desenvolvido sem a participação do Poder Judiciário, e, no final, o resultado não gera apenas efeitos administrativos, mas também um efeito criminal muito importante, que é a extinção da punibilidade daquela pessoa que supostamente cometeu um ato criminoso. Nesse aspecto está a maior vulnerabilidade das regras de leniência.'

Para Dall'Acqua, 'a participação dos Ministérios Públicos no acordo firmado é uma prova de que tanto a SDE quanto o CADE se ressentem de segurança em relação ao próprio acordo.'

Na opinião dele, os Ministérios Públicos são chamados para dar mais legitimidade ao acordo. 'Mas isso não apaga a inconstitucionalidade do acordo. Contudo, a promotoria também não tem o poder de extinguir a punibilidade. Esse é um poder somente do Judiciário', completa Dall'Acqua." ${ }^{, 500}$ 
A doutrina também expõe de que maneira deve ser declarada a inconstitucionalidade dos dispositivos da Lei $\mathrm{n}^{\circ}$ 8.884/94:

\footnotetext{
"Aplica-se, nesta análise, a doutrina da divisibilidade das leis, reconhecida e utilizada pelo Supremo Tribunal Federal. Por esta teoria, também devem ser declarados inconstitucionais os artigos que, embora isoladamente possam ser válidos, são conexos ao trecho ofensivo à Constituição. Esta conexão se manifesta quando os dispositivos legais se mostram perfeitamente integrados, concorrendo para a mesma finalidade e que, ademais, não teriam sido criados separadamente pelo legislador. Diante deste quadro, não só o artigo eivado de inconstitucionalidade deve ser tido como inaplicável mas também as demais partes da lei que com ele mantém integração."501
}

Esse o contexto, não há outra solução que não considerar inconstitucional o artigo 35-C, da Lei $\mathrm{n}^{\circ} 8.884 / 94$, eis que viola frontalmente o princípio fundamental da reserva de jurisdição.

Ainda que não se entenda assim, ao menos se deve reconhecer a insegurança jurídica que o dispositivo apresenta ao leniente, porquanto diante da reserva de jurisdição, a decisão administrativa que extingue automaticamente a punibilidade - sequer homologada por um juiz togado - pode não surtir efeitos na esfera judiciária, o que leva o Programa de Leniência a perder os seus atrativos para a delação.

De um modo ou de outro, é preciso alterar o dispositivo legal, a fim de determinar a participação do Poder Judiciário na análise dos termos do acordo de leniência, atribuindo, exclusivamente ao magistrado, a função de decidir pela suspensão da pretensão punitiva estatal e pela extinção da punibilidade dos crimes praticados pelo leniente, após um criterioso, mas não automático, exame do cumprimento das obrigações contidas no instrumento celebrado.

\footnotetext{
${ }^{501}$ OLIVEIRA LIMA, José Luis; DALL'ACQUA, Rodrigo. Ordem econômica. A inconstitucionalidade do acordo de leniência.
} 


\subsubsection{Provas produzidas em acordo de leniência sem êxito}

Uma outra questão nevrálgica dos reflexos do instituto consiste no sigilo - ou sua ausência - das provas produzidas por seu intermédio e da possibilidade de estas serem utilizadas posteriormente, quando da não celebração efetiva do acordo. ${ }^{502}$

$\mathrm{Na}$ realidade, o legislador preocupou-se em dispor na Lei de Defesa da Concorrência a respeito das provas produzidas em acordo de leniência sem êxito, determinando o seguinte: "Não importará em confissão quanto à matéria de fato, nem reconhecimento de ilicitude da conduta analisada, a proposta de acordo de leniência rejeitada pelo Secretário da SDE, da qual não se fará qualquer divulgação.” 503

O dispositivo legal assegura ao candidato a leniente o sigilo de suas informações, de modo que as autoridades antitruste ficam impedidas, no caso de insucesso do acordo, de se utilizarem dos termos de sua delação, bem como de todos os elementos probatórios por ele fornecidos na tentativa da celebração do ajuste.

Mas a ausência de critérios determinados, claros e garantidores do sigilo das informações traz imensa insegurança ao delator, desestimulando-o a celebrar o acordo. Não há garantia alguma de que a proposta de ajuste será aceita pelas autoridades e ainda de que, na hipótese de fracasso, as provas fornecidas pelo proponente não formem um incontestável quadro probatório autoincriminatório.

Não à toa, o relatório apresentado em 2005, a pedido do governo brasileiro, pela Organização para a Cooperação e Desenvolvimento Econômico (OCDE), elaborado com a

\footnotetext{
${ }^{502}$ Essa preocupação torna-se ainda mais intensa ao notar que os Estados Unidos da América, cuja legislação inspirou o nosso Programa de Leniência, é um dos países que prevê expressamente em sua política a possibilidade de utilização das provas apresentadas pelo candidato a leniente contra ele mesmo. (Cf.: "Should the Antitrust Division revoke the conditional acceptance of Applicant into the Corporate Leniency Program, the Antitrust Division may thereafter initiate a criminal prosecution against Applicant, without limitation. Should such a prosecution be initiated, the Antitrust Division may use against Applicant in any such prosecution any documents, statements, or other information provided to the Division at any time pursuant to this Agreement by Applicant or by any of its current [or former] directors, officers, or employees". Tradução livre: "Na hipótese de a Divisão Antitruste revogar a aceitação condicional do candidato no Programa de Leniência Corporativo, ela pode, em seguida, iniciar uma persecução criminal contra o candidato, sem limitações. No caso de instaurada uma persecução, a Divisão Antitruste pode usar contra o candidato, em qualquer procedimento e a qualquer tempo, quaisquer documentos, depoimentos ou outras informações fornecidas à Divisão nos termos deste Acordo pelo candidato ou por qualquer um de seus diretores, executivos ou funcionários atuais ou já desligados da empresa". (ESTADOS UNIDOS DA AMÉRICA. DEPARTMENT OF JUSTICE. Model corporate conditional leniency letter).

${ }^{503}$ Artigo 35-B, § 10 da Lei no $8.884 / 94$.
} 
colaboração do Banco Interamericano de Desenvolvimento (BID), expôs duras críticas ao nosso programa de "suavização", recomendando expressamente que o Brasil o modifique para “[...] adotar regulamentos assegurando que provas incriminatórias fornecidas por candidatos à participação no programa de leniência não serão utilizadas contra eles se não forem considerados aptos para a assinatura do acordo. „504

O relatório afirma, ainda, o seguinte:

\begin{abstract}
"A lei em vigor prevê (Art. 35-B, § 10) que o SBDC deve manter a confidencialidade das informações dos candidatos à leniência que, mais tarde, provarem não ser elegíveis; estabelece, ainda, que essas informações não serão consideradas como uma admissão de que a parte estava envolvida na conduta em questão, ou que a conduta é ilegal. Contudo, a lei não limita a utilização interna das informações pelo próprio SBDC. Esta é uma outra forma de exposição ao risco que pode evitar a participação em acordos de leniência. O SBDC deveria adotar regulamentos que proibissem os funcionários envolvidos na participação do programa de revelar ao pessoal da investigação qualquer informação confidencial que tenha sido fornecida dos candidatos ao programa, após haverem sido considerados inelegíveis." ${ }^{205}$
\end{abstract}

Na tentativa de atender aos reclamos da OCDE, a regulamentação do Programa de Leniência veio se desenvolvendo e se aprimorando, culminando na promulgação da Portaria do Ministério da Justiça $n^{\circ} 456 / 2010$, que também aborda o sigilo das provas produzidas em acordo sem êxito. Este ato normativo assim dispõe sobre o assunto:

\footnotetext{
“[...]

Art. 68. Não importará em confissão quanto à matéria de fato, nem reconhecimento da ilicitude da conduta analisada, a proposta de Acordo de Leniência rejeitada, da qual não se fará qualquer divulgação.
}

\footnotetext{
504 BRASIL. MINISTÉRIO DA JUSTIÇA. CADE. Relatório sugere mudanças para a área de concorrência. P. 10.

${ }^{505}$ Idem, ibidem, p. 119. Um outro relatório elaborado pela OCDE em 2002 assim consignou a esse respeito: "A confidencialidade é importante à clemência, em virtude do fato de que os informantes podem sofrer um alto risco de retaliação, bem como ações criminais em outras jurisdições. Um elevado risco de que as informações possam ser repassadas para outras jurisdições poderia diminuir os incentivos da firma para entregar-se”. (OCDE. Using leniency to fight hard core cartels. Overview).
} 
Art. 70. Caso o acordo não seja alcançado, todos os documentos serão devolvidos ao proponente, não permanecendo qualquer cópia na Secretaria de Direito Econômico.

Parágrafo único. Na hipótese do caput deste artigo, o Secretário de Direito Econômico e a Chefia de Gabinete não poderão fazer uso das informações fornecidas pelo proponente, principalmente não poderão transmitir, sob qualquer forma, tais informações ao Departamento de Proteção e Defesa Econômica."

Não se pode negar que houve uma intensa preocupação das autoridades em preservar o candidato a leniente, garantindo, sobretudo, a inutilização das provas apresentadas por ele, já que a documentação deverá ser integralmente devolvida "[...] não permanecendo qualquer cópia ou original na Secretaria de Direito Econômico.”

Ainda que exista óbice para a transmissão das informações colhidas para o Departamento de Proteção e Defesa da Concorrência, não há garantia alguma de que os funcionários dos diferentes setores não se comuniquem, deixando transparecer algum indício, ainda que mínimo, do ilícito narrado pelo proponente.

Em sua Cartilha de combate a cartéis e programa de leniência, a Secretaria de Direito Econômico abordou essa questão dos acordos não concluídos da seguinte maneira:

"Propostas de Acordo de Leniência que não resultem em sua assinatura não implicam confissão quanto à matéria de fato nem reconhecimento de ilicitude da infração relatada. Nesse caso, não se fará qualquer divulgação da proposta e eventuais documentos obtidos pela SDE durante a negociação serão devolvidos ao proponente, não ficando nenhuma cópia em poder da SDE.

Além disso, há um Chinese Wall entre o Secretário da SDE e o seu Departamento de Proteção e Defesa Econômica (DPDE): o DPDE não participa do processo de negociação do Acordo de Leniência. Caso nenhum acordo seja alcançado e o DPDE inicie posteriormente, com base em informações obtidas por conta própria, uma investigação da conduta em 
questão, o Secretário declarar-se-á impedido e não poderá revelar informações fornecidas pelo proponente." 506

A respeito da chamada Muralha da China criada entre as autoridades antitruste, a Secretaria de Direito Econômico comprometeu-se publicamente no sentido de que

\begin{abstract}
"[...] a equipe da Secretaria que viu um requerimento de leniência não tenha resultado em acordo fica impedida de participar de casos relativos ao setor de mercado em questão (criando uma 'Muralha da China' para isolar a informação de qualquer exploração imprópria na aplicação da lei)." ${ }^{507}$
\end{abstract}

Porém, não parece que o fato de prever uma Muralha da China imaginária, sem que exista uma fiscalização intensa e, até, previsão de punições no caso de descumprimento desse pacto de silêncio, obste totalmente a comunicação entre os diferentes setores.

Torna-se de capital importância um rígido controle sobre a atuação desses servidores da Secretaria de Direito Econômico e do Departamento de Proteção e Defesa da Concorrência para que nem mesmo um simples comentário acerca da conduta delatada pelo candidato a leniente seja feito entre funcionários.

A demonstrar ainda mais a fraqueza do sistema, a Cartilha de combate a cartéis $e$ programa de leniência traz hipótese em que o secretário de Direito Econômico pode noticiar a existência de acordo de leniência em negociação ao Departamento de Proteção e Defesa da Concorrência:

\footnotetext{
"Durante a negociação do Acordo, o DPDE poderá, com base em suas próprias fontes de informação, recomendar ao Secretário de Direito Econômico a instauração de processo administrativo sobre a mesma conduta relatada pelo proponente. Em juízo de oportunidade e conveniência, de modo a preservar o potencial da investigação, o Secretário poderá dar notícia ao Diretor do DPDE que há um Acordo de Leniência em negociação, sem
}

\footnotetext{
${ }^{506}$ BRASIL. MINISTÉRIO DA JUSTIÇA. SECRETARIA DE DIREITO ECONÔMICO. Cartilha sobre combate a cartéis e programa de leniência. Pp. 29/30.

${ }^{507}$ OCDE. Lei e política de concorrência no Brasil: uma revisão pelos pares, p. 55.
} 
identificar o proponente nem revelar qualquer informação fornecida. Em seguida, o Secretário dará notícia ao proponente acerca da investigação do DPDE, de modo a incentivar a conclusão do Acordo. Se o Acordo não for celebrado, o DPDE poderá investigar a prática, sendo que o Secretário de Direito Econômico estará impedido e não poderá revelar informações fornecidas pelo proponente.",508

Ora, se o secretário pode comunicar ao diretor do Departamento a existência de acordo de leniência em andamento, no mínimo este último, responsável pela apuração das condutas ilícitas, sabe que houve uma delação sobre a formação de um cartel; ou seja, ainda que não tenha conhecimento de seus termos nem detenha provas suficientes, sabe que o cartel existiu. Não se tem mais averiguações preliminares em busca da verdade real, pois esta já é certa, bastando que se produzam provas nesse sentido.

Além disso, não se sabe em quais termos a notícia da existência desse acordo de leniência ocorre. A Cartilha é um tanto quanto reticente sobre o tema e não há permissivo legal a esse respeito; assim, mais uma vez, encontra-se sem amparo o candidato a leniente, ficando ao talante do sentir do secretário da Secretaria de Direito Econômico, de acordo com seu "juízo de oportunidade e conveniência", o seu destino.

A insegurança ao candidato torna-se mais evidente ao se observar que nos dias atuais a própria imprensa é capaz de obter e divulgar informações resguardadas pelo segredo de justiça. De fato, é mais fácil para um órgão administrativo, já de posse de informações tão valiosas originadas de um acordo de leniência fracassado, por vias oficiais ou oblíquas, divulgá-las ou levá-las ao conhecimento do Ministério Público, que, sujeito ao princípio da obrigatoriedade, deveria propor ação penal em face do proponente. $\mathrm{O}$ risco, nesses casos, é patente. ${ }^{509}$

\footnotetext{
${ }^{508}$ BRASIL. MINISTÉRIO DA JUSTIÇA. SECRETARIA DE DIREITO ECONÔMICO. Cartilha sobre combate a cartéis e programa de leniência. Pp. 30.

${ }^{509}$ CASTELO BRANCO, Fernando. Op. cit., p. 157.
} 
Na mesma linha, diante da insegurança trazida pela possível utilização da delação promovida, JOÃO GRANDINO RODAS adverte que “[...] a empresa deve preferir, sempre que possível propor a celebração do acordo de leniência oralmente e não por escrito. "510

Há quem argumente que diante dos fatos delatados, mesmo que não seja firmado o acordo, “[...] não poderia a SDE restar engessada a tomar providências, o que seria um inverso estímulo à procura demasiada e desmedida a partir de toda e qualquer informação suspeita."

Respeitadas as opiniões em contrário, não é crível que o Programa de Leniência se sustente amparado em bases tão frágeis como essas. A permissão para a Secretaria de Direito Econômico transmitir a quem de direito as informações fornecidas pelo proponente é extremamente prejudicial à atração de novos delatores, especialmente por apresentar imensurável insegurança jurídica ao colaborador.

A incerteza sobre o acolhimento de sua proposta - e, principalmente, sobre os reflexos do acordo na área penal - passa a ser tamanha que o programa chega a fracassar. O candidato a leniente somente comparecerá à Secretaria de Direito Econômico quando estiver totalmente certo de que sua proposta será acolhida, isto é, nunca.

Urge relembrar que o chamariz do Programa de Leniência é a imunidade penal como moeda de troca pelas informações e provas apresentadas às autoridades antitruste. A partir do momento em que não tiver esta contraprestação, nem a mínima certeza de que ela ocorrerá, não mais existirá interesse na apresentação espontânea da verdade real dos fatos. Não mais haverá a corrida pela leniência, mas sim a corrida da leniência.

\subsubsection{Acordo de leniência e a prática de crimes não previstos na Lei $n^{\circ} 8.137 / 90$}

A Lei de Defesa da Concorrência prevê expressamente, em seu artigo 35-C, que apenas “[...] nos crimes contra a ordem econômica, tipificados na Lei $n^{\circ} 8.137$, de 27 de novembro de 1990 [...]" (grifos nossos). A celebração do acordo de leniência determinará

\footnotetext{
${ }^{510}$ RODAS, João Grandino. Acordos de leniência em direito concorrência. P. 32. A esse respeito, conferir também International Competition Network, Drafting and Implementing an Effective Leniency Program. P. 08

${ }^{511}$ SANTOS, André Maciel Vargas dos. Op. cit., p. 14.
} 
a suspensão do curso do prazo prescricional e impedirá o oferecimento de denúncia. Diante deste fato, somente com relação a esses crimes, cumprido o acordo pelo agente, será automaticamente extinta a sua punibilidade. Na mesma linha, a Portaria do Ministério da Justiça $\mathrm{n}^{\circ}$ 456, de 15 de março de 2010, regulamentou os benefícios do acordo em seu artigo 75.512

Resulta claro da leitura desses dispositivos que o acordo de leniência e seus efeitos no âmbito penal restringem-se aos delitos contra a ordem econômica tipificados na Lei $\mathrm{n}^{\circ}$ $8.137 / 90$. Isto significa que, ante o relato do colaborador para as autoridades antitruste da prática de um ou mais delitos - sejam todos crimes contra a ordem econômica ou não apenas aqueles tipificados na referida Lei serão abrangidos pelos efeitos da imunidade penal.

Assim, se o candidato à leniência decidir por narrar a prática delituosa de maneira minuciosa, apresentando provas documentais, indicando os envolvidos, esmiuçando o modus operandi utilizado pelos membros do cartel e, em razão disso, acabar por revelar a sua participação na prática de outros crimes relacionados, somente verá extinta a punibilidade dos crimes tipificados na Lei $\mathrm{n}^{\mathrm{o}}$ 8.137/90. No que tange aos demais delitos, por certo, verá instaurada contra si uma ação penal.

Se de uma narrativa da formação de um crime de cartel restar evidenciado o cometimento do delito de falsidade ideológica, uso de documento falso, ameaça, quadrilha ou qualquer outro ilícito penal, ainda que diretamente relacionado ao cartel como crimemeio para a prática da conduta cartelizadora, estes não serão objeto da imunidade penal, pelo contrário, serão apurados em um processo penal.

A agravar tal situação, as ações penais instauradas para apurar tais crimes trarão um acervo probatório invejável, apresentando peças acusatórias bem fundamentadas e consistentes, porquanto terão como premissa a confissão do agente, que assumiu, perante a

\footnotetext{
512 “[...] Art. 75. Uma vez declarado o cumprimento do Acordo de Leniência pelo Conselho Administrativo de Defesa Econômica, será decretada em favor do signatário do Acordo de Leniência:

I - A extinção da ação punitiva da administração pública, nas hipóteses em que a proposta do Acordo de Leniência tiver sido apresentada à Secretaria de Direito Econômico sem que essa tivesse conhecimento prévio da infração noticiada; ou

II - Nas demais hipóteses, a redução de um a dois terços das penas aplicáveis na seara administrativa.

Parágrafo único. Nas duas hipóteses referidas acima, extingue-se automaticamente a punibilidade dos crimes tipificados na Lei $n^{\circ}$ 8.137, de 27 de novembro de 1990." (grifos nossos)
} 
Secretaria de Direito Econômico, o compromisso de apresentar todo o tipo de prova que detiver, ainda que pese contra si, para auxiliar na descoberta da verdade.

É inegável que tal consequência representará um forte desestímulo para o agente à celebração do acordo de leniência. Os benefícios decorrentes da política de leniência passarão a representar não mais um atraente motivo para a delação e desmantelamento do cartel, mas sim uma temerosa armadilha para obtenção de provas contra o próprio candidato a leniente para a instrução de futuras ações penais.

Qual o interesse do agente em confessar o seu envolvimento na prática criminosa e delatar os demais membros do cartel se não haverá óbice algum na instauração de ações penais contra ele? Qual seria o benefício, a recompensa em troca da traição? Por qual motivo deixaria de manter-se silente, lucrando com a prática criminosa se, ao máximo, conseguiria atingir a extinção da punibilidade parcial dos delitos? Qual o sentido da delação com um prêmio parcial?

A razão de ser do acordo de leniência - "pilar fundamental da Política Nacional de Proteção da Ordem Econômica" - não mais subsiste. A leniência não mais adquire contornos de brandura, não traz qualquer vantagem relevante aos olhos daquele agente que se envolveu em outros crimes, além da formação do cartel.

Por isso, o já mencionado relatório elaborado pela Organização para a Cooperação e Desenvolvimento Econômico (OCDE) recomendou, em 2005, que o Brasil modificasse seu Programa de Leniência para "[...] impedir que participantes do programa de leniência sejam processados com base em outras leis criminais que não a Lei de Crimes contra a Ordem Econômica."

Ainda assim, até hoje nada foi feito. Na mesma linha, outro relatório, elaborado em 2010 pela OCDE, ressaltou novamente a importância desta modificação no Programa de Leniência:

\footnotetext{
513 Acerca do tema, o relatório consigna ainda que: “A previsão legal relativa ao acordo de leniência existente na Lei 8884 (Art. 35-C) protege as partes que colaboram em denúncias sob os artigos da Lei brasileira Crimes contra a Ordem Econômica (Nr. 8137/90), mas não evita a aplicação de outras leis criminais (como aquelas contra fraude e conspiração), às quais os participantes de cartéis também podem estar sujeitos. Os incentivos para que o membro de um cartel busque celebrar um acordo de leniência acaba sendo limitado pela exposição a esse risco. A Lei deve ser alterada para evitar qualquer processo criminal de conduta que constitua uma violação da lei da concorrência e que seja a base da condição de uma empresa como participante de um programa de leniência." (OCDE. Lei e política de concorrência no Brasil: uma revisão pelos pares. Pp. 10 e 118).
} 
7.2.1.9. Modificar o Programa de Leniência para eliminar a exposição dos beneficiários da leniência a outros processos penais, para além da Lei de Crimes contra a Ordem Econômica.

O Programa de Leniência do SBDC está provando ser bem sucedido, e tem gerado diversas candidaturas. O Programa estipula que os indivíduos que receberem leniência também receberão imunidade na ação criminal sob a Lei de Crimes contra a Ordem Econômica. Entretanto, eles não recebem atualmente imunidade no âmbito de outras leis criminais que possam ser aplicadas a casos de conduta. Isto pode inibir alguns interessados de se candidatarem no Programa de Leniência." 514

A situação passa a ser ainda mais assustadora quando se observa que um tipo penal presente em nossa legislação, que também prevê e reprime uma conduta cartelizadora, não está inserido na tão divulgada imunidade penal.

É o caso do delito de cartel em licitações, previsto no artigo 90, da Lei $\mathrm{n}^{\circ}$ 8.666/93. ${ }^{515} \mathrm{O}$ raciocínio é simples: tendo em vista que os benefícios penais do acordo de leniência cingem-se aos crimes contra a ordem econômica apresentados pela Lei $\mathrm{n}^{\mathrm{o}}$ 8.137/90, todos os demais delitos - inclusive o crime de cartel em licitações, que, além de estar previsto em outra lei, tutela bem jurídico diverso ${ }^{516}$ e não se enquadra nos ilícitos penais de natureza econômica - não estão abarcados pelos benefícios do instituto.

A incongruência salta aos olhos, à medida que se verifica o objetivo primordial do instituto da leniência, qual seja, o agressivo combate aos crimes de cartel e não apenas aos delitos econômicos previstos na Lei nº 8.137/90. A intenção dos órgãos antitruste é clara: detectar e aniquilar a prática de formação de cartéis, independentemente do diploma legal que suporte formalmente esta conduta ilícita.

\footnotetext{
${ }^{514}$ OCDE. Lei e política de concorrência no Brasil: uma revisão pelos pares - 2010.

515 “[...] Art. 90. Frustrar ou fraudar, mediante ajuste, combinação ou qualquer outro expediente, o caráter competitivo do procedimento licitatório, com o intuito de obter, para si ou para outrem, vantagem decorrente da adjudicação do objeto da licitação: Pena - detenção, de 2 (dois) a 4 (quatro) anos, e multa.”

${ }^{516}$ De acordo com VICENTE GRECO FILHO, no artigo 90 da Lei $\mathrm{n}^{\circ}$ 8.666/93, “[...] o bem jurídico amparado é a moralidade e regularidade do procedimento licitatório" (GRECO FILHO, Vicente. Dos crimes da lei de licitações. P. 16).
} 
Nesse particular, José LuIS OliveIRA LIMA e RODRIGO DALL'ACQUA analisam a possibilidade de celebração de acordo de leniência quando praticado o delito de cartel em licitações:

"O principal e mais óbvio motivo para a inaplicabilidade dos benefícios penais é o fato de que o crime de celebração de acordo para frustar o caráter competitivo de uma licitação é tipificado na Lei nº 8.666, de 1993, conhecida como Lei de Licitações. Ademais, conceitualmente, é pacífico que os chamados cartéis em licitação são classificados como crimes contra a administração pública, já que ferem não só a competitividade do certame, mas também atentam contra a moralidade e regularidade do procedimento licitatório. Assim, por não estar previsto na Lei $n^{\circ} 8.137$, e, também, por não ser considerado como ilícito contra a ordem econômica, ao cartel em licitação não podem ser aplicados os efeitos penais de um acordo de leniência.

No cenário jurídico atual, a leniência até pode ser celebrada em relação aos cartéis em licitações, mas sem que seja oferecida e aplicada a imunidade penal. Ou seja, tudo o que a lei vigente oferece é a confissão de uma fraude licitatória em troca da isenção da punição administrativa, mas sem a concessão da imunidade criminal, em um acordo tremendamente desvantajoso e altamente não recomendável para o leniente." 517

Ao contrariar as previsões legais, em sua Cartilha sobre combate a cartéis em licitação, a Secretaria de Direito Econômico declara expressamente que no cartel previsto na Lei de Licitações, o acordo de leniência é o instrumento adequado para se obter as imunidades penal e administrativa. Ela menciona, inclusive, a título de exemplo, o caso do cartel de vigilantes no Rio Grande do Sul, no qual foi firmado o primeiro acordo de leniência do Brasil. ${ }^{518}$

Essa orientação das autoridades antitruste vai de encontro aos ditames legais, sendo absolutamente temerosa a celebração de um acordo de leniência nesses termos. Isto porque, todo processo penal decorrente deste instrumento poderá fracassar, sendo declarado nulo, com fulcro nos artigos 157 e 564, inciso IV, do Diploma Processual Penal, eis que baseado em prova flagrantemente ilícita.

517 OLIVEIRA LIMA, José Luis; DALL'ACQUA, Rodrigo. Os cartéis em licitação e o acordo de leniência.

${ }^{518}$ BRASIL. MINISTÉRIO DA JUSTIÇA. SECRETARIA DE DIREITO ECONÔMICO. Cartilha sobre combate a cartéis em licitações. P. 18. 
Não se está aqui sentenciando que não é possível celebrar um acordo de leniência diante da prática de formação de cartel em licitações. Isso é plenamente admissível. Porém, deve-se atentar para o fato de que não há óbice algum para o Ministério Público oferecer denúncia em face do leniente com relação a este delito. No âmbito penal, não haverá suspensão do curso do prazo prescricional penal nem extinção da punibilidade do agente, conforme previsto no artigo 35-C, parágrafo único, da Lei nº 8.884/94.

O leniente, se cumprido o acordo, apenas será agraciado com a redução de um a dois terços da penalidade administrativa aplicável ou com a extinção da ação punitiva da administração pública, isto é, o seu acordo produzirá efeitos somente na esfera administrativa, eis que a concessão de tais benefícios depende tão somente das próprias autoridades celebrantes.

No que tange ao delito de quadrilha, quando imputado em conjunto com o crime de cartel, tem-se outra celeuma. Entende-se que nesta imputação há clamoroso bis in idem.

Não é outro o posicionamento de MigUEL REALE JÚNIOR:

\begin{abstract}
"A figura típica de quadrilha ou bando, não constitui uma configuração de crime autônomo em relação aos crimes que a associação criminosa pretende ou vem a realizar, como se dá na quadrilha ou bando, por exemplo, para se praticar roubo ou seqüestro. Nesses casos os fatos são diversos, as condutas independentes, autônomas. No cartel, ao contrário, a associação é dado elementar de sua realização típica, constante do ditame legal e evidentemente da realidade à qual o tipo do cartel é congruente.

Destarte, a mesma conduta recebe a incidência concomitante de duas normas penais. Sucede, portanto, um concurso aparente de normas, que se resolve pelos critérios da especialidade, da subsidiariedade ou da consunção."
\end{abstract}

$\mathrm{O}$ autor prossegue apresentando argumentos em defesa de sua tese:

\footnotetext{
"No crime de quadrilha ou bando, previsto no art. 288 do Código Penal, há ações paralelas de cada participante com o fim de cometer crimes, sendo cada um autor e não co-autor. No crime de cartel igualmente o concurso é
}

${ }^{519}$ REALE JÚNIOR, Miguel. Cartel e quadrilha ou bando: bis in idem. P. 140. 
necessário, pois se realiza por meio de acordo ou ajuste entre pessoas que são os sujeitos ativos do crime.

No concurso necessário a pluralidade de sujeitos ativos não é uma eventualidade, mas sim dado elementar do tipo penal, sendo um 'dado técnico-legislativo que expressa relevo fundante e essencial à lesão real ou potencial ao bem jurídico tutelado'. Assim, a exigência de uma pluralidade de sujeitos ativos decorre do tipo que por sua vez colhe essa estrutura plural na própria realidade, pois só a pluralidade de atores principais como assinalados no tipo pode criar uma situação de ofensa ao bem jurídico.

\section{(...)}

No plano subjetivo o concurso necessário requer, evidentemente, que cada sujeito ativo possua conhecimento da ação do outro, com ciência de estarem realizando de um mesmo tipo penal, em condutas que se entrelaçam.

Incidem, portanto, sobre a conduta do cartel duas normas incriminadoras em marcado bis in idem, a ser resolvido pelos critérios do concurso aparente de normas." 520 (grifos do autor)

Embora seja possível, diante do contexto jurídico atual, que o Ministério Público instaure uma ação penal em face do leniente para apurar o seu envolvimento no delito de quadrilha, em tese praticado em conjunto com o crime de formação de cartel - ainda que tenha sido declarada extinta a sua punibilidade com relação a este último -, o conceito do bis in idem impede esta prática. Mas infelizmente, não tem sido esta a atividade corriqueira dos órgãos ministeriais.

Ante essas ponderações, conclui-se pela necessidade de se ampliar a abrangência dos benefícios penais concedidos em função da celebração de um acordo de leniência. Estes deverão estar disponíveis não só com relação aos crimes contra a ordem econômica previstos na Lei $n^{\circ} 8.137 / 90$, mas também a toda prática cartelizadora caracterizada como ilícito penal - tal como a conduta disposta no artigo 90 da Lei de Licitações -, independentemente da lei que albergue o tipo penal. Afinal, o acordo de leniência foi adotado pelas autoridades concorrenciais com a finalidade de combater a formação de cartéis, em defesa da concorrência, dos consumidores e dos concorrentes, e não os delitos de natureza econômica previstos na Lei ${ }^{\circ} 8.137 / 90$.

${ }^{520}$ Idem, ibidem, p. 141. 
Ademais, ultimamente, a legislação penal pátria vem evoluindo de maneira esparsa e desorganizada, com a criação frequente de novos tipos penais em variados diplomas legais, ainda que sobre a mesma matéria ou com vistas a tutelar os mesmos bens jurídicos. Tal fato permite que novos crimes mais específicos de formação de cartel - com sujeitos e nichos de mercado determinados ou com modus operandi especiais - venham a ser previstos em novas leis e, do mesmo modo que o cartel em licitações, não estarão acobertados pela suspensão de seu prazo prescricional ou mesmo da imunidade penal quando da celebração de um acordo de leniência nos termos da legislação atual.

Também os delitos diretamente relacionados à prática do crime de cartel deverão estar sujeitos aos benefícios previstos no artigo 35-C da Lei $n^{\circ} 8.884 / 94$. Isto significa que não devem ser punidos os chamados crimes-meio para a realização do crime-fim de formação de cartel, tais como: o delito de falsidade de documento público ou particular, o uso de documento falso, a ameaça e a quadrilha - este último na hipótese de não acolhimento do posicionamento acima exposto.

O benefício da imunidade penal de todos os crimes envolvidos na conduta anticoncorrencial - inclusive daqueles intimamente relacionados à prática cartelizadora, pois cometidos em uma etapa intermediária como simples meio para atingir o fim maior, que é o cartel - trará maior segurança ao participante do cartel; isto para que forneça às autoridades antitruste todas as informações e detalhes concernentes ao ajuste, ainda que os elementos levados ao conhecimento da Secretaria de Direito Econômico revelem o seu envolvimento em novos crimes.

Tal raciocínio merece ressalvas. Os demais delitos eventualmente praticados pelo candidato a leniente, ainda que cometidos sob o mesmo contexto fático e, de alguma forma, relacionados à formação de cartel, não serão abrangidos pelos benefícios penais. A relação indireta com o crime de cartel não permitirá a suspensão de seu prazo prescricional e a extinção da punibilidade penal do leniente, sob pena de o acordo de leniência representar uma verdadeira carta branca para a prática de delitos de todos os gêneros, passando de um instrumento de luta contra os cartéis para uma verdadeira alforria para os criminosos.

À guisa de exemplo, tem-se a prática de homicídios de concorrentes, corrupção de funcionários públicos, porte ilegal de armas e lavagem de dinheiro, que, apesar de poderem 
estar relacionados com a prática do delito concorrencial, não são crimes-meio para a formação do cartel tampouco necessários para a sua consumação.

\subsubsection{Questão prejudicial}

Como visto anteriormente, o Programa de Leniência provoca efeitos tanto na esfera administrativa quanto na penal. A partir de um acordo celebrado com a União, por intermédio de um órgão administrativo, o leniente confessa sua participação no ilícito administrativo, a princípio, já que analisado apenas sob esse viés pelo órgão competente e fornece todas as informações que detém a respeito da prática da conduta.

Com base nessas informações, constatada a consumação do ilícito administrativo relatado, é instaurado um procedimento administrativo, a fim de melhor apurar a conduta anticoncorrencial, imunizando totalmente o delator ou promovendo uma redução nas futuras sanções que lhe serão aplicadas.

Paralelamente, a Secretaria de Direito Econômico, com todo o seu conhecimento técnico e diante da identidade de infrações administrativas e penais na ambiência concorrencial, transaciona na esfera penal, de maneira que o delator conquista a extinção de sua punibilidade com relação ao ilícito penal praticado, enquanto os demais partícipes sofrerão, ao menos, uma investigação criminal.

Assim, uma única conduta praticada será apurada tanto no âmbito administrativo, a partir de um processo administrativo que tramitará na Secretaria de Direito Econômico, quanto no penal, mediante um Inquérito Policial e, posteriormente, uma eventual Ação Penal instaurada em face dos demais infratores. Isto porque, salta aos olhos a perfeita identidade entre as infrações administrativas e penais no que se refere aos crimes contra a ordem econômica, notadamente, aos cartéis. Basta uma análise perfunctória sobre os artigos 20 e 21 da Lei $n^{\circ} 8.884 / 94$, bem como sobre os artigos $4^{\circ}, 5^{\circ}$ e $6^{\circ}$ da Lei $n^{\circ} 8.137 / 90$ para constatar a assertiva.

Ainda que a responsabilidade administrativa seja diversa da penal, admitindo-se naquela a responsabilidade objetiva, repudiada em absoluto no Direito Penal, as expressões e termos técnicos utilizados para a configuração da infração administrativa e do tipo penal 
são os mesmos. É inegável que os termos típicos da área econômica, como "abuso de poder econômico", "dominação de mercado", "eliminação total ou parcial da concorrência", "fixação artificial de preços" serão melhor compreendidos se analisados por órgão técnico e especializado que pelo juízo penal.

Forçoso reconhecer, destarte, que o processo administrativo em trâmite na Secretaria de Direito Econômico do CADE exerce influência fundamental sobre a esfera penal, de modo que não é possível proferir juízo de valor em Ação Penal a respeito de condutas ínsitas à área econômica sem a análise final de órgão especializado sobre o assunto.

A despeito disso, não é razoável que uma única conduta tenha desfechos diversos nas áreas administrativa e penal, em razão exclusivamente de interpretações equivocadas sobre termos técnicos de órgão inexperiente e despreparado para julgar condutas específicas. $^{521}$

Diante dessa total independência de esferas, é concebível que o órgão administrativo entenda uma conduta como irrelevante para a livre concorrência ou para a ordem econômica como um todo e, simultaneamente, o juízo penal a interprete como altamente lesiva para a concorrência, havendo absolvição em um processo e condenação em outro.

Essa temerosa insegurança jurídica, observada também nos crimes contra a ordem tributária, conduz invariavelmente à reflexão acerca da necessidade de suspensão do processo penal até o deslinde final do procedimento administrativo especificamente nos casos de condutas lesivas à ordem econômica.

A esse respeito, assim se manifestou ANDRÉ MACIEL VARGAS DOS SANTOS:

\footnotetext{
"Destarte, questiona-se: qual o fundamento de levar-se a efeito punição criminal, quando o próprio ente responsável pela fiscalização do setor não constata a lesividade em determinadas condutas. Eis, então, a importância de que o processo administrativo integre as condições de justa causa para o
}

\footnotetext{
${ }^{521}$ Cabe aqui a uma ressalva: é admissível que processos criminais e administrativos tenham desfechos diferentes em decorrência da diversa aferição da responsabilidade nas duas ambiências e de especificidades e elementos contidos nos tipos penais.
} 
recebimento da denúncia, agindo como uma verdadeira condição objetiva de punibilidade.

E bem assim se demonstra a questão dos crimes contra a ordem econômica. A existência do CADE revela o interesse estatal na fiscalização e repressão dentro da matéria. E, como é de seu interesse aumentar o desvelo de condutas lesivas à livre concorrência, uma vez que, conforme já explicado, são de difícil percepção, o Estado age por meio da autarquia negociando as penas, relevando certas situações em busca de uma maior efetividade da sua atuação. Nessa esteira, fácil é a comparação da atuação do CADE com a dos órgãos fazendários no que diz respeito ao resguardo do bem jurídico em questão, em cada um dos casos.

Assim como, por exemplo, a Receita Federal é a responsável por instaurar o processo fiscal e perseguir o crédito tributário, se for o caso, o CADE é o responsável por verificar a ocorrência de abuso do poder econômico e agir no que lhe cabe, quer seja impondo sanções, quer seja abrindo mão da reprimenda porque mais lhe interessa uma visão mais ampla do que tem acometido negativamente o mercado.

Não se aguardar o pronunciamento final da autoridade administrativa representa, por via indireta, cerceamento de defesa e indevida mitigação do princípio do devido processo legal, pois pouco adianta disponibilizar ao administrado o direito ao recurso ou desobrigar-lhe a garantir a instância, se, por outro lado, fica sujeito, antes de julgamento aos ônus, limitações, percalços e humilhações." 522

No entender do autor, os crimes contra a ordem econômica deveriam receber o mesmo tratamento conferido aos crimes contra a ordem tributária, os quais somente podem ser apurados após o pronunciamento final do órgão administrativo, isto é, se o crédito tributário já estiver constituído no âmbito administrativo. ${ }^{523}$

\footnotetext{
522 SANTOS, André Maciel Vargas dos. Op. cit., pp. 21/22.

${ }^{523}$ Cf. "Tal qual, por exemplo, os crimes contra a ordem tributária, a lesão ao bem jurídico tutelado pende de elementos a serem verificados pelo órgão administrativo. Ocorre que o crime de suprimir ou reduzir tributos é material, depende a sua perfectibilização da efetiva constituição e plena exigibilidade do crédito tributário pelo Fisco, o qual detém a exclusiva competência para tanto.

Recentemente, observou-se radical alteração no tratamento conferido pelo Supremo Tribunal Federal, aos crimes de sonegação fiscal, em especial aos elencados no artigo $1^{\circ}$, da Lei $n^{o} 8.137$ de 1990 . No intuito de evitarem-se manifestas ilegalidades, o STF adotou a idéia de que a constituição definitiva do crédito tributário e a sua exigibilidade figuram como condição objetiva de punibilidade, uma das condições específicas da ação. (...) O que se verifica é que uma ação criminal proposta sem que o órgão fazendário no caso do exemplo citado - tenha encerrado o seu procedimento é nula, porque a denúncia basear-se-ia em fato cuja punibilidade penderia de fatores que poderão ou não ocorrer. Antes de encerrado o processo
} 
Não se abraçou aqui o posicionamento defendido pelo autor, segundo o qual a análise da conduta pelo Cade consistiria em uma condição objetiva de punibilidade; partilhou-se, sim, com ele do mesmo entendimento acerca da necessária suspensão do processo penal até o pronunciamento final da autoridade administrativa sobre a existência de lesividade à ordem econômica.

\title{
Na opinião de HELENO CLÁUdio Fragoso,
}

\begin{abstract}
“[...] condições de punibilidade são acontecimentos exteriores ao tipo, que a lei estabelece como indispensáveis à punibilidade do fato. Tais condições não são necessariamente alheias à conduta e à culpabilidade. As condições objetivas de punibilidade são, sem sombra de dúvida, elementos suplementares do tipo, mas não se incluem no mesmo, caracterizando-se precisamente pelas circunstâncias de serem exteriores. Saber se os acontecimentos a que nos referimos condicionam a aplicação da pena ou a própria existência do crime, é questão que depende, de certa forma, da solução dada a uma e outra, ou seja, depende do próprio conceito do crime." $^{\text {"524 }}$
\end{abstract}

$\mathrm{Na}$ realidade, não é esse o caso em apreço. As expressões de cunho eminentemente econômico que definem a lesividade das condutas à ordem econômica constituem verdadeiros elementos dos tipos penais dispostos na Lei ${ }^{\circ} 8.137 / 90$, de modo que não podem ser consideradas exteriores.

Ao se trazer à tona essa mesma celeuma, LEONARDo SICA aborda a questão com pertinentes ponderações:

\footnotetext{
"Por fim, quanto à possibilidade de conflito entre decisões do CADE e da justiça penal, o fato mais importante para ser tomado como premissa é, exatamente, a identidade entre as condutas tipificadas nas leis. Essa peculiaridade impõe a adoção de solução hermenêutica diferenciada, ao
}

\footnotetext{
administrativo, não será possível a formação válida da relação processual, tendo em vista que poderá o réu vir a ser declarado isento de pena. Enfim, é dada a competência privativa para verificar a ocorrência do fato gerado da responsabilidade tributária ao Poder Executivo. Dessa maneira, nenhum outro órgão pode dizer que houve a sonegação se, de antemão, não tiver acontecido o lançamento fiscal." 523 (SANTOS, André Maciel Vargas dos. Op. cit., pp. 21/22).

${ }^{524}$ FRAGOSO, Heleno Cláudio. Lições de direito penal. P. 266.
} 
reverso do que pode ocorrer em outras áreas onde a interface penaladministrativo também é forte (meio ambiente, ordem tributária, etc.). Aqui, ambas as esferas sempre poderão processar e julgar os mesmos fatos (jurídicos), contudo, em tempo e racionalidade diversas.

Considerando o direito penal econômico como estrutura macro em que se inclui essa discussão, uma solução viável pode ser construída por meio de analogia com o atual entendimento jurisprudencial dominante na questão dos crimes tributários, que estão tipificados na mesma Lei n. 8.137/90.

(..)

O raciocínio desenvolvido para consolidar esse entendimento pode ser seguido para os casos de crime contra a ordem econômica. Evidentemente, não se trata de equiparar as situações, pois a exigibilidade do tributo é elemento típico daqueles crimes e, nisso, não há qualquer semelhança.

Mas há nos crimes contra a ordem econômica elementos típicos como 'abuso de poder econômico', 'posição dominante de mercado', 'fixação artificial de preços' que, à evidência, não podem ser definidos a partir de avaliação exclusiva do tribunal criminal. Faltam conhecimento, método e recursos técnicos para afirmar, com a mínima segurança, a ocorrência de alguma dessas elementares no âmbito do processo penal. Mesmo no direito econômico, por exemplo, é totalmente controversa a definição de dominação do mercado. Tais constatações dependem de análises econométricas complexas e o CADE é o órgão competente para gerenciar essa tarefa." ${ }^{25}$ (grifos do autor)

O autor ressalva as possíveis e negativas consequências decorrentes da apreciação pelo juízo penal de questões de ordem técnica, quais sejam, contrariedade entre as esferas administrativa e penal, repetição de provas e impossibilidade de celebração do acordo de leniência. $^{526}$

A título de ilustração, tem-se o conhecido caso do "cartel dos cegonheiros", no qual se apurou um suposto acordo entre a Associação Nacional dos Transportadores de

\footnotetext{
${ }^{525}$ SICA, Leonardo. Op. cit., pp. 171/173.

${ }^{526} \mathrm{Cf}$. "Não se pode olvidar, ainda que inúmeras são as conseqüências danosas deriváveis do fato de a justiça penal pronunciar-se, por exemplo, acerca do abuso de poder econômico sem aguardar a manifestação das agências administrativas: (i) contrariedade entre as esferas administrativa e penal, com a primeira verificando que não ocorreu abuso de poder econômico e a segunda condenando alguém pelo abuso; (ii) repetição de provas: teriam que ser feitas em juízo e no processo administrativo, onerando, desnecessariamente o Estado e a administração da Justiça; (iii) nega-se a possibilidade de o agente celebrar acordo de leniência no curso da ação administrativa." (Idem, ibidem, pp. 175/176).
} 
Veículos (ANTV) e o Sindicato Nacional dos Transportadores Rodoviários Autônomos de Veículos, Empresas Individuais, Pequenas e Micro Empresas de Transporte Rodoviário de Veículos (SINDICAN), que impedia empresas não cadastradas perante essas entidades de transportar veículos automotores novos pelas rodovias do País, fato que caracterizaria uma prática anticoncorrencial.

Tais fatos, ocorridos entre os anos de 2000 e 2003, foram investigados nos âmbitos administrativo e penal em procedimentos que tramitaram de maneira absolutamente independente, o que permitiu desfechos diferentes e contraditórios para o mesmo caso.

$\mathrm{Na}$ esfera penal, a suposta prática do delito de cartel foi apurada nos autos da Ação Penal $n^{\circ}$ 2003.71.00.007397-5 $5^{527}$ instaurada em face de Aliberto Alves, presidente do Sindican, Paulo Roberto Guedes, diretor-presidente da ANTV, e Luiz Moan Yabiku Júnior, diretor para assuntos institucionais da General Motors do Brasil Ltda.

Em 19 de junho de 2006, após toda a instrução processual e antes que se aguardasse a decisão final do órgão administrativo, foi prolatada sentença que constatou a existência da prática anticompetitiva, condenando os três acusados. ${ }^{528}$

Já no Procedimento Administrativo no 080.12.005669/2002-31, julgado pelo Plenário do CADE em 21 de novembro de 2007, determinou-se o arquivamento do feito basicamente em virtude de duas questões. A primeira refere-se à fragilidade das provas produzidas, porquanto não se logrou demonstrar o acordo entre os agentes econômicos e porque inúmeros depoimentos que respaldavam a tese acusatória foram prestados por pessoas interessadas na condenação dos representados. A segunda diz respeito à

\footnotetext{
${ }^{527}$ Este processo tramitou perante a $3^{\text {a }}$ Vara Criminal da Seção Judiciária de Porto Alegre/RS.

${ }^{528}$ Aliberto Alves foi condenado como incurso no artigo $4^{\circ}$, incisos I, $a$ e $f$, II, $a, b$ e $c$ e VII da Lei $n^{\circ}$ $8.137 / 90 \mathrm{c} / \mathrm{c}$ o artigo 71 do Código Penal à pena de cinco anos e três meses de reclusão; Paulo Roberto Guedes foi condenado como incurso no artigo $4^{\circ}$, incisos II, $a, b$ e $c$ e VII da Lei $\mathrm{n}^{\circ} 8.137 / 90$ c/c o artigo 71 do Código Penal à pena de quatro anos, dois meses e 20 dias de reclusão; Luiz Moan Yabiku Júnior foi condenado como incurso no artigo $4^{\circ}$, inciso I, $a$ e $f$ da Lei $\mathrm{n}^{\circ} 8.137 / 90 \mathrm{c} / \mathrm{c}$ o artigo 71 do Código Penal à pena de três anos e nove meses de reclusão, substituída por duas penas restritivas de direito (BRASIL. TRIBUNAL REGIONAL FEDERAL DA 4 ${ }^{\mathrm{a}}$ REGIÃO. Processo $n^{\circ}$ 2003.71.00.007397-5).

Inconformados com a sentença condenatória, os acusados interpuseram recurso de apelação, o qual foi julgado pelo Tribunal Regional Federal da $4^{\mathrm{a}}$ Região em 2 de março de 2010. Naquela ocasião, determinouse a remessa dos autos à origem para oferecimento de suspensão condicional do processo. Desse acórdão, o Ministério Público Federal interpôs Recurso Especial, posteriormente, inadmitido e, em seguida, Agravo de despacho denegatório de Recurso Especial, ao qual foi negado provimento em 25 de abril de 2011. Os acusados, por sua vez, interpuseram Recursos Especiais (apenas Aliberto Alves e Paulo Roberto Guedes) e, ainda, Recursos Extraordinários, todos pendentes de julgamento pelos Tribunais Superiores.
} 
inconsistência da hipótese do fechamento de mercado concentrado, ressaltando o conformismo das empresas montadoras com o hipotético ajuste. ${ }^{529}$

Como se vê, a independência das instâncias pode gerar uma colidência de decisões administrativas e judiciais, até quando as infrações apuradas são praticamente idênticas nas duas esferas, como ocorre na formação de cartel. Não é aceitável que um órgão administrativo técnico possa julgar uma questão irrelevante para a concorrência nacional e o Poder Judiciário, em clara afronta a essa decisão, entender que estes fatos caracterizam um delito concorrencial.

A solução para essa discussão já está prevista no ordenamento jurídico pátrio, basta interpretar a dúvida econômica como questão prejudicial da ação penal. Ao se considerar a definição das expressões econométricas como antecedente lógico-jurídico da questão penal, é inaceitável o prosseguimento da persecução penal sem o pronunciamento final do CADE acerca da matéria. Tal antecedência lógico-jurídica configura, na doutrina, questão prejudicial, ou seja, “[...] questão jurídica cuja solução constitua um pressuposto para a decisão da controvérsia submetida a juízo. "530 É, portanto, regulamentada, por analogia, pelo artigo 93 do Estatuto Processual Penal. ${ }^{531}$

Deste modo, enquanto não esgotada a via administrativa, com pronunciamento final da autarquia federal acerca da conduta supostamente atentatória à ordem econômica, suspende-se o processo penal. Sim, pois a decisão administrativa incidirá diretamente na averiguação da existência ou não de um delito. Nem há que se falar em inexistência de ação cível para a solução da dúvida econômica, pois o procedimento administrativo acaba por produzir os mesmos efeitos da demanda judicial. É questão inegavelmente prejudicial à causa penal e de impossível resolução pelo juízo penal.

Razoável, nesse sentido, a suspensão concomitante da prescrição penal, consoante disposição do artigo 116, inciso I do Código Penal. ${ }^{532}$ Isto porque, considerando que há um

529 Procedimento Administrativo $\mathrm{n}^{\mathrm{o}}$ 080.12.005669/2002-31. (BRASIL. MINISTÉRIO DA JUSTIÇA. CADE).

${ }^{530}$ MANZINI, Vicenzo. Trattato di diritto penale. Pp. 500/501.

531 “[...] Art. 93. Se o reconhecimento da existência da infração penal depender de decisão sobre questão diversa da prevista no artigo anterior, da competência do juízo cível, e se neste houver sido proposta ação para resolvê-la, o juiz criminal poderá, desde que essa questão seja de difícil solução e não verse sobre direito cuja prova a lei civil limite, suspender o curso do processo, após a inquirição das testemunhas e realização de outras provas de natureza urgente."

532 “[...] Art. 116. Antes de passar em julgado a sentença final, a prescrição não corre: 
óbice legal temporário à resolução da lide penal, decorrente de uma questão prejudicial, não faz sentido algum que o prazo do direito de punir do Estado continue a fluir.

Não é aceitável a imposição de obstáculos legais proibitivos da punição se, quando ultrapassados, for inviável a continuidade da persecução penal, em virtude da ocorrência da prescrição. Ademais, é admissível que a suspensão do processo penal se prolongue por provocação da própria parte beneficiada pelo instituto da prescrição, pela interposição de recursos infindáveis, sendo este mais um motivo para a suspensão do prazo prescricional. Caso contrário, o Estado seria penalizado por possibilitar ao acusado a ampla defesa e o duplo grau de jurisdição.

Em que pese a razoabilidade deste posicionamento, a jurisprudência vem se manifestando em sentido diametralmente oposto. Indubitavelmente, escassos são os julgados que abordam a questão do esgotamento da via administrativa pelo CADE para o prosseguimento do processo penal. No entanto, todos eles seguem a mesma linha em defesa da total independência das instâncias. ${ }^{533}$

I - enquanto não resolvida, em outro processo, questão de que dependa o reconhecimento da existência do crime; [...]"

${ }^{533}$ Nesse diapasão, os seguintes julgados do Tribunal Regional Federal da $4^{\text {a }}$ Região e do Superior Tribunal de Justiça:

“PENAL. HABEAS CORPUS. CRIMES CONTRA A ORDEM ECONÔMICA. ART. $4^{\circ}$ DA LEI N" 8.137/90. ABUSO DE PODER ECONÔMICO. CADE. PROCEDIMENTO ADMINISTRATIVO PENDENTE. DECISÃO. QUESTÃO PREJUDICIAL. ART. 93, CPP. CONDIÇÃO DE PROCEDIBILIDADE. MATERIALIDADE. ATIPICIDADE. INOCORRÊNCIA.

1. Conforme o art. 93 do CPP, as questões prejudiciais facultativas poderão ensejar, a critério do juiz, a suspensão da ação penal e do respectivo prazo prescricional desde que tenha sido proposta ação cível para a solução do tema, bem como seja a controvérsia de difícil solução e não verse sobre direito cuja prova a lei civil limite;

2. O elemento 'abuso do poder econômico' constante do tipo penal previsto no art. $4^{o}$ da Lei $n^{o} 8.137 / 91$ não deve ser considerado questão prejudicial, visto que não preenche as condições previstas no art. 93 do CPP, mormente quando há somente procedimento administrativo pendente perante o CADE - Conselho Administrativo de Defesa Econômica, inexistindo ação cível;

3. $O$ nosso ordenamento jurídico é regido pela independência entre as esferas penal e administrativa, sendo que o término do procedimento administrativo não é requisito para o exercício da pretensão punitiva estatal quando estão presentes todos os elementos necessários ao recebimento da denúncia e o processamento da ação penal." (HC n ${ }^{\circ}$ 2004.04.01.049719-0, Rel. Des. Fed. Tadaaqui Hirose, Sétima Turma, DJ 26.01.05. No mesmo sentido: no 2004.04.01.049738-3, Rel. Des. Fed. Tadaaqui Hirose, Sétima Turma, DJ 26.01.05) "PENAL E PROCESSUAL PENAL. HABEAS CORPUS SUBSTITUTIVO DE RECURSO ORDINÁRIO. ABUSO DE PODER ECONÔMICO. ART. 4', INCISO II, ALÍNEAS A, B E C, E INCISO VII, C/C ART. 12, INCISO I, AMBOS DA LEI N ${ }^{\circ}$ 8.137/90. DECISÃO DO CADE. ART. 93, DO CPP. Considerar que a decisão do CADE sobre abuso de poder econômico reflete situação paralela à do Conselho de Contribuintes em matéria tributária é equivocado. O Conselho de Contribuintes vai dar o quantum debeatur que configura a condição objetiva de punibilidade, segundo a Augusta Corte. Na hipótese do CADE, é mera apreciação administrativa sobre a existência de abuso de poder econômico. Não é condição objetiva de punibilidade e sim uma valoração acerca daquilo que coincide com o elemento do tipo. E sendo elemento do tipo, o procedimento administrativo no CADE não enseja a discussão em torno do art. 93 do CPP. Writ denegado." 
Vale destacar trecho do voto proferido pelo Ministro JosÉ ARNALDO DA FONSECA por ocasião do julgamento do Habeas Corpus no 42.305 no Superior Tribunal de Justiça, que apresentou posicionamento diverso e restou vencido pela maioria dos julgadores:

\footnotetext{
"Contudo, ao ouvir atentamente a sustentação do ilustre advogado, na linha do que dispõe o art. 93 do CPP, considero razoável a discussão não só pela ótica do procedimento administrativo perante o CADE, mas sobretudo pela existência da ação civil pública, iniciada pelo Ministério Público. Advirto que a questão do abuso do poder econômico, independentemente das conotações legais, cinge-se especificamente à evolução das relações da economia de Mercado no qual o país está ingerido, cujas transformações na última década permitiram a constatação de fenômenos específicos sujeitos a especializações longe do caminho eminentemente jurígeno. Daí porque, nesta rápida introspecção, em meio à faculdade estendida ao Juiz pelo art. 93 do Estatuto Processual, ressaltando, também, os precedentes do administrativo-fiscal, não vejo motivo para negar a suspensão da ação penal, se a matéria é, sim, de difícil constatação."
}

A matéria carece de certo amadurecimento por parte do Poder Judiciário, assim como ocorreu com os crimes contra a ordem tributária. Paulatinamente, na medida em que a questão for sendo apresentada aos tribunais, suscitarão maiores reflexões que conduzirão a essa nova solução.

\subsubsection{Mecanismos de solução alternativa de procedimento administrativo: acordo de leniência e termo de compromisso de cessação de prática}

A Lei $\mathrm{n}^{\mathrm{o}}$ 11.482, de 31 de maio de 2007, introduziu na Lei $\mathrm{n}^{\circ}$ 8.884/94 a possibilidade de o CADE celebrar acordos com empresas e indivíduos investigados por prática de cartel, determinando-se o seguinte:

(HC n 42.305, Rel. Min. José Arnaldo da Fonseca, Quinta Turma, DJ 05.09.05. Na mesma linha: RHC $\mathrm{n}^{\circ}$ 17.418, Rel. Min. José Arnaldo da Fonseca, Quinta Turma, DJ 27.03.06). Também a jurisprudência dos Tribunais de Justiça seguem no mesmo sentido: TJRS, HC nº 70009727181, Rel. Des. José Eugênio Tedesco, Quarta Câmara Criminal, j. em 30.09.04. 
"Em qualquer das espécies de processo administrativo, o CADE poderá tomar do representado compromisso de cessação da prática sob investigação ou dos seus efeitos lesivos, sempre que em juízo de conveniência e oportunidade, entender que atende aos interesses protegidos por lei." 534

O denominado Termo de Compromisso de Cessação de Prática consiste em um acordo proposto pelo suposto infrator representado em um processo administrativo ao CADE, com vistas a interromper eventual prática investigada durante um período preestabelecido. $^{535}$ Durante este prazo, suspende-se o processo administrativo e, se constatado o cumprimento integral das obrigações pelo representado, este é definitivamente arquivado. ${ }^{536}$

É caracterizado, portanto, como “[...] um meio alternativo de solução de conflitos envolvendo direitos transindividuais em risco diante de determinadas práticas econômicas. " 537

Para sua celebração com o CADE, é fixada uma contribuição pecuniária a ser recolhida ao Fundo de Defesa de Direitos Difusos, sendo indicado um valor de multa para a hipótese de descumprimento do acordo.

Para alguns estudiosos do tema, “[...] o Termo de Compromisso de Cessação é um instituto de Direito Econômico decorrente da descaracterização da natureza penal e da

\footnotetext{
${ }_{534}^{53}$ Antigo art. 53, $\$ 5^{\circ}$ da Lei $n^{\circ} 8.884 / 94$, incluído pela Lei $n^{\circ} 10.149 / 00$.

${ }^{535}$ Carla lobão assim define o instituto: "O Compromisso de Cessação de Prática - CCP é um instrumento de composição de conflitos concorrenciais, previsto no artigo 53 da Lei n. 8.884, de 11 de junho de 1994 (Lei de Defesa da Concorrência), cujo objetivo é o restabelecimento imediato do funcionamento regular do mercado, por meio da cessação espontânea, pelo representado, da conduta investigada." (LOBÃO, Carla. Compromisso de cessação de prática: uma abordagem crítica sobre o instituto. P. 87)

${ }_{536}$ Ao realizar uma análise comparativa sobre os dois institutos, anteriormente à promulgação da Lei ${ }^{\circ}$ 11.482/07, asseverou IBRAHIM ACÁCIO ESPíRITO SOBRAL: "O acordo de leniência possui uma amplitude e grau de sofisticação maiores que o compromisso de cessação. O acordo de leniência é mais abrangente, já que exige que o delator ofereça provas da conduta ilícita de outros agentes econômicos, o que não se verifica no Termo de cessação, no qual o infrator simplesmente compromete-se em cessar a sua prática infrativa, não exigindo dele qualquer comprovação de práticas a terceiros. O compromisso de cessação por si só não dispõe de elementos suficientes para a descoberta e desmantelamento de cartéis. Aliás, o compromisso de cessação pode dizer respeito a qualquer infração à Ordem Econômica, ao passo que o acordo de leniência visa especificamente combater cartéis." (SOBRAL. Ibrahim Acácio Espírito. Op. cit., p. 141).

${ }^{537}$ RODRIGUES, Geisa de Assis. Breves considerações sobre o compromisso de cessação de prática. In: ROCHA, João Carlos de Carvalho et alli (coord.). Lei antitruste: 10 anos de combate ao abuso do poder econômico. P. 122.
} 
aceitação da natureza político-econômica da lei da concorrência." ${ }^{538}$ Com a alteração legal, a Lei de Defesa da Concorrência - que anteriormente vedava expressamente a aplicação dos Termos de Compromisso de Cessação de Prática aos casos de cartel, ${ }^{539}$ entendendo, à época, que este ilícito seria tão deletério à ordem econômica que a Administração Pública não poderia transigir a punição nessa hipótese - veio a permiti-los em qualquer caso que esteja sob investigação nos órgãos do Sistema Brasileiro de Defesa da Concorrência.

Tal previsão, em linhas gerais, passou a incentivar os investigados por esse delito a recorrer às autoridades, a fim de solucionar seu procedimento administrativo, sem temer que isso fizesse eclodir, de imediato, uma persecução penal, pois não haveria implicação em confissão quanto à matéria de fato nem o reconhecimento da ilicitude da conduta.

Todavia, tempos após a promulgação desta lei, o CADE publicou a Resolução $\mathrm{n}^{\circ}$ $46 / 2007,{ }^{540}$ que determinou a obrigatoriedade da confissão da culpa na celebração do Termo de Compromisso de Cessação em processos nos quais já houvesse acordo de "lenidade", fazendo surgir uma gritante incompatibilidade entre esses dois institutos. ${ }^{541}$

Deste modo, em que pese o fato de haver determinação legal expressa para que a proposta deste Termo pelo investigado, que pode ser feita uma única vez, não implique confissão quanto à matéria de fato nem o reconhecimento da ilicitude da conduta, criando incentivos para ele recorrer à autoridade sem recear que isso afete o desfecho do processo caso o termo não seja celebrado, ${ }^{542}$ a Resolução passou a exigir a confissão em todos os compromissos donde presente acordo de leniência. ${ }^{543}$

\footnotetext{
538 NERY, Daniel Christianini. A confissão na apuração de cartéis e os benefícios concedidos pela autoridade antitruste.

${ }_{539}$ Assim dispunha a antiga redação do artigo 53, da Lei no $8.884 / 94$, em seu $§ 5^{\circ}$ :

“[...] Art. 53 (...) $\$ 5^{\circ} \mathrm{O}$ disposto neste artigo não se aplica às infrações à ordem econômica relacionadas ou decorrentes das condutas previstas nos incisos I, II, III, e VIII do art. 21 desta Lei.”

${ }^{540}$ Promulgada em 06 de setembro de 2007, a Resolução no 46 aprova a Emenda Regimental no 01/2007, que altera os artigos 76, 129 e 130 do Regimento Interno, aprovado pela Resolução CADE $n^{\circ}$ 45/07, e regulamenta o artigo 53 da Lei $n^{\circ} 8.884 / 94$.

${ }^{541}$ O artigo 129-G do Regimento Interno do CADE ficou assim redigido: “[...] Art. 129-G - Nos casos em que houver sido celebrado acordo de leniência pela SDE, o compromisso de cessação deverá necessariamente conter reconhecimento de culpa por parte do compromissário. Nos demais casos, a exigência da confissão de culpa ficará a critério do CADE."

${ }_{542}$ ROSENBERG, Bárbara. Investigações de cartel e acordos. P. 57.

${ }^{543}$ PEDRO VICENTINI esclarece que "Ao definir no art. 129-G do Ricade que a confissão de culpa é requisito essencial nos casos em que houver sido celebrado acordo de leniência pela SDE, o Cade claramente extrapolou suas competências legais e violou o princípio constitucional da legalidade." (VICENTINI, Pedro.
} 
De antemão, sob o enfoque puramente administrativo, DANIEL FERRAZ CóRDOVA e MARIANA REBUZZI SARCINELli LOPES criticam o instituto, considerando-o altamente prejudicial ao acordo de leniência:

"Este aumento na abrangência da aplicação dos TCCs deve ser melhor analisado, uma vez que entendemos que não houve uma prévia análise do mercado brasileiro, de uma forma geral, bem como da viabilidade do aumento desta abrangência na atual legislação concorrencial brasileira.

\section{(...)}

A possibilidade de ser firmado TCC nas condutas configuradas como cartéis diminui significativamente a força do Acordo de Leniência.

Um dos requisitos mais importantes para a existência de um acordo de leniência estável e forte é a determinação legal e a aplicação, pelos órgãos de defesa da concorrência, de altas multas pecuniárias impostas aos participantes do cartel.

(...)

$\mathrm{O}$ acordo de leniência não tem como objetivo apenas acabar com o cartel, mas também puni-lo com o devido rigor e, acima de tudo, desencorajar a prática da conduta e encorajar que aqueles que participam do cartel colaborem com a realização da justiça e dos maiores valores do Estado Democrático de Direito.

\section{(..)}

Entretanto, o trâmite do TCC é extremamente rápido, pois o período de negociação entre o CADE e a empresa será de 30 (trinta) dias, contados do despacho do Conselheiro Relator, sendo prorrogáveis, no máximo, por mais 30 (trinta) dias e, concluído o período de negociação, a versão final do compromisso será pautada em caráter de urgência pelo Conselheiro Relator para julgamento pelo Plenário do CADE, ou seja, após a apresentação do TCC, haja vista o curto lapso temporal até o seu julgamento, será difícil verificar a vantagem auferida pela empresa na participação no cartel.

Assim, o CADE, caso o TCC seja firmado no início do processo administrativo, não disponibilizará de dados suficientes para quantificar a vantagem auferida pela empresa em sua participação no cartel. Não tendo estes dados, o CADE, provavelmente, irá estipular a multa mínima determinada no art. 23 , da Lei ${ }^{\circ} 8.884 / 1994$, qual seja, um por cento do

A confissão de culpa nos Termos de Compromisso de Cessação: requisito essencial ou prescindível, face ao programa de leniência? P. 270). 
faturamento bruto do último exercício, excluídos os impostos, e, mesmo que o CADE disponha de alguns dados, provavelmente não terá, haja vista que o processo administrativo não terá sido finalizado, informações suficientes para impor uma multa de acordo com a vantagem auferida para empresa em sua participação no cartel, como ocorre na União Européia e nos Estados Unidos da América do Norte.

A empresa, ao obter conhecimento de que o CADE e a SDE estão investigando um suposto cartel de que ele é participante, irá 'correr' para firmar o TCC, para que o CADE não tenha acesso a informações suficientes para impor uma multa que não seja a mínima.

A multa, quando estipulada em seu valor mínimo, não inibe a empresa de participar do cartel, pois os lucros auferidos com a participação nesta prática serão maiores que a multa por ventura imposta em caso de ser firmado o TCC." ${ }^{, 544}$ (grifos dos autores)

Em defesa do acordo de leniência, DANIEL Christianini Nery expõe seu posicionamento, apontando para a necessidade do reconhecimento de culpa nos Termos de Compromisso de Cessação de Prática, a fim de torná-lo mais gravoso em confronto com a leniência. ${ }^{545}$ É sempre útil para a administração pública firmar um Termo de Compromisso

${ }^{544}$ CÓRDOVA, Danilo Ferraz; LOPES, Mariana Rebuzzi Sarcinelli. Op. cit., pp. 87/88. (grifos do autor).

${ }^{545} \mathrm{Cf}$. "Mas a atual discussão acerca deste tema tem sido a obrigatoriedade ou não de o TCC incluir necessariamente a indicação de que as empresas efetivamente participaram nas condutas investigadas.

(...) Como dito anteriormente, a investigação e instrução de casos de cartel clássico são altamente intensivas em recursos humanos e materiais e podem demorar muito tempo para serem concluídas. Os acordos podem, de fato, contribuir na eficácia do sistema, na medida em que antecipa as medidas punitivas. Já para a Administração Pública, a vantagem de firmar um acordo está na redução do uso de seus recursos, na melhoria da qualidade da investigação e na maior celeridade.

Porém, como na maior parte dos casos de cartel existem muitos participantes envolvidos, para os quais deve ser garantida a ampla defesa, um acordo com um deles ou alguns deles só representaria efetiva economia de recursos, celeridade e eficácia na decisão se houvesse reconhecimento da participação na prática investigada e colaboração, no sentido de confirmar a existência do ilícito ou trazer novas provas ao caso. Nos casos em que o proponente tenha sido objeto de busca e apreensão, o teor do tal TCC deveria também incluir o reconhecimento da legalidade desta busca e apreensão, para que seja almejada economia de recurso, sem perda de eficácia no combate a cartéis.

Não basta a oportunidade em se realizar um acordo de leniência ou um TCC. É necessário que também seja conveniente para a Administração Pública utilizar este instrumento. Há um amplo reconhecimento de que é mais eficaz encerrar o processo de forma antecipada, garantindo uma contribuição pecuniária suficiente para coibir a prática da infração e manter o fundamento punitivo, do que manter um processo durante vários anos.

E justamente por este motivo a regulamentação do CADE sobre o tema permite, a critério da autoridade antitruste, exigir ou não esta confissão.

E é neste sentido que tanto a Secretaria de Direito Econômico - SDE, quanto a Procuradoria do CADE atualizaram seu posicionamento, passando a pugnar pela existência de reconhecimento de culpa no caso de pessoas jurídicas em todo e qualquer acordo em processos de cartel. A motivação expressa nesses novos procedimentos é a preservação do programa de leniência. 
de Cessação de Prática, na medida em que há uma grande economia de recursos e o desfecho do processo administrativo, além de trazer a certeza quanto à arrecadação de recursos imediatos para o Fundo de Defesa de Direitos Difusos, torna-se efetivamente mais célere. $^{546}$

Afora isso, independentemente da confissão da prática da conduta ilícita, haverá o recolhimento de valores para os cofres públicos, com a pretendida cessação da prática anticoncorrencial. ${ }^{547}$ Por outro lado, sabe-se que sem a confissão, é provável que detalhes acerca da prática ilícita não sejam revelados, de modo que, possivelmente, alguns participantes da conduta anticompetitiva serão resguardados.

\section{É considerável a questão levantada por DANIEl FERRAZ CóRdova e MARIANA}

REBUZZI SARCINELli LOPES no sentido da possibilidade de tornar-se mais reduzida a contribuição pecuniária estabelecida no ajuste, tornando-a uma espécie de taxa de legalização do cartel. Seria esse o preço da escolha em abrir mão do prosseguimento normal do procedimento administrativo.

\footnotetext{
Isso porque certamente este acordo deve ser mais gravoso ao proponente do que o acordo de leniência, amparado pela Lei 10.149/00. Neste sentido, para o primeiro proponente de um acordo, deve ser sempre mais vantajoso firmar o acordo de leniência, enquanto aos demais a vantagem pode estar na finalização antecipada do processo e na segurança da decisão e do quantum a ser pago, em face de provável condenação e imposição de multa ao final. Todavia, a leniência, que deveria ser uma alternativa melhor ao acusado, já conta intuitivamente com uma confissão de participação na conduta anticoncorrencial." (NERY, Daniel Christianini. Op. cit.).

${ }^{546}$ A cartilha Política da SDE - Termo de Compromisso de Cessação de Prática em cartel aponta três benefícios decorrentes do instituto para a administração pública e a sociedade: "O primeiro benefício é a economia de tempo e recursos. Quando um investigado por prática de cartel celebra um TCC, os recursos e tempo que seriam utilizados para a investigação daquele envolvido serão economizados, o que na prática significa a liberação de parte dos escassos recursos disponíveis para o empreendimento de novas investigações. A economia de recursos para a Administração também se traduz pelo fato de que não haverá recurso ao Poder Judiciário por parte de tal investigado, liberando recursos que antes seriam usados em litígios judiciais.

O segundo benefício é tornar a instrução do processo administrativo em curso contra os demais investigados mais célere, eficiente e precisa por meio, essencialmente, da cooperação ativa do interessado em firmar o TCC.

Em terceiro lugar, um TCC em caso de cartel possibilita o recolhimento imediato de contribuição pecuniária em benefício da sociedade." (BRASIL. MINISTÉRIO DA JUSTIÇA. CADE. Política da SDE - Termo de Compromisso de Cessação de prática em cartel. P. 01, grifos no original).

${ }^{547}$ CARLA LOBÃO aponta os benefícios do TCC tanto para o Poder Público quanto para o representado: " $O$ CCP, sem sombra de dúvida, tem o condão de reduzir sensivelmente os custos envolvidos na atividade investigatória, os custos decorrentes da morosidade e lentidão dos processos administrativo e judicial; os custos da incerteza quanto ao desfecho do processo, e, principalmente, de fazer com que a intervenção indireta do Estado na ordem econômica seja eficaz, ao recompor, de forma mais célere e efetiva, as condições concorrenciais do mercado.

De outra parte, para o representado, os benefícios do CCP, também são indiscutíveis. Poupa-lhe os custos financeiros decorrentes do processo; a inconveniência de ter a sua atividade econômica sendo investigada e a sua imagem desgastada, bem como o risco de um julgamento desfavorável." (LOBÃO, Carla. Op. cit., p. 91).
} 
Só que aqui a preocupação vai além, pois a exigência apresentada pela Resolução $n^{\circ} 46 / 07$ traz reflexos radicais na própria adesão dos supostos infratores tanto ao Termo de Compromisso de Cessação de Prática quanto ao acordo de leniência.

Nesse sentido, BÁRBARA RoSENBERG expôs sua preocupação, asseverando que

\begin{abstract}
"Se, por um lado, a exigência de confissão pode ser necessária para preservar a eficácia do programa de leniência, teme-se que essa regra limite o número de empresas a propor o acordo, pois referida confissão pode ter efeitos negativos no âmbito criminal e no que diz respeito a ações judiciais de ressarcimento de dano. ${ }^{, 548}$
\end{abstract}

É cediço que, para que não haja um abandono do acordo de leniência - lembre-se, pilar fundamental do combate aos cartéis -, é fundamental atribuir ao Termo de Compromisso de Cessação de Prática contornos mais gravosos, admitindo-se, para tanto, a exigência da confissão. ${ }^{549}$ Deste modo, o acordo de "abrandamento" sempre será mais atraente por trazer consigo a imunidade penal, ante o reconhecimento da culpa na prática do delito.

Apresentado nesses termos, o Termo de Compromisso de Cessação de Prática não seduz representado algum, eis que, além de impor uma sanção pecuniária de imediato que, talvez, com o trâmite normal do procedimento administrativo, não venha a se efetivar -, acarretará, naturalmente, uma posterior e bem instruída, principalmente com a própria

\footnotetext{
548 ROSENBERG, Bárbara. Op. cit., p. 57. No mesmo sentido, Eduardo Molan Gaban e Juliana OLIVEIRA DOMINGUES entendem que "[...] a exigência de confissão de culpa nesse caso elide a aplicação de referida norma (ou seja, celebração do TCC), vez que atrai para aquele que assim proceder a probabilidade de ser acionado no âmbito civil em ações de reparação de danos ao mesmo tempo em que representa uma confissão do ilícito em matéria criminal." (GABAN, Eduardo Molan; DOMINGUES, Juliana Oliveira. Direito antitruste: o combate aos cartéis. P. 304).

${ }^{549}$ Acerca do tema, assim dispõe a cartilha Política da SDE - Termo de Compromisso de Cessação de Prática em cartel: "Nesse contexto, emerge a importância de não se firmar TCCS que resultem na subpunição do investigado pela prática de cartel clássico, o que poderia tornar o TCC uma opção mais atraente do que o Acordo de Leniência. Nesse cenário, uma empresa participante de um cartel teria fortes incentivos para continuar a prática ilícita e, na eventualidade de o Poder Público detectar a conduta por investigação própria e obter provas suficientes para a sua condenação, celebrar, no início do processo, momento no qual não foi realizada instrução probatória, um TCC sem reconhecimento de participação na prática e sem exigência de colaboração ativa com as investigações. O investigado assim se furtaria, naturalmente, de suas demais responsabilidades perante a sociedade pela prática de cartel, entre elas a indenização perante terceiros prejudicados pelo cartel." (BRASIL. MINISTÉRIO DA JUSTIÇA. CADE. Política da SDE Termo de Compromisso de Cessação de prática em cartel. P. 04, grifos no original).
} 
confissão do investigado, persecução penal. ${ }^{550}$ Isto significa que, quando celebrado um acordo nesses moldes, o investigado não se encontra amparado na esfera penal e pode não obter vantagem alguma na esfera administrativa. A insegurança jurídica é patente.

Diante dessas alterações legais e administrativas, a Secretaria de Direito Econômico adotou uma política que, ao invés de sanar esta indesejada insegurança, resguardando a existência do instituto, pareceu reforçá-la.

Na cartilha apresentada sob o título Política da SDE - Termo de Compromisso de Cessação de Prática em Cartel, já de início, a Secretaria de Direito Econômico exaltou a necessidade de se exigir a confissão nesses acordos pelos seguintes motivos:

"A SDE entende que a celebração de um TCC apenas atenderá o interesse público se os termos do acordo forem aptos a (i) preservar o Programa de Leniência, que é o principal instrumento da política de combate a cartéis no Brasil; (ii) dissuadir futuras práticas lesivas à concorrência; e (iii) não criar obstáculos à persecução administrativa e criminal de cartéis, bem como a ações privadas de indenização por danos causados por tal prática anticoncorrencial'.

Resta claro que para atingir os objetivos acima há que se exigir a confissão da participação na prática por parte do compromissário nos casos em que houver sido celebrado Acordo de Leniência. Por motivos óbvios, não se quer permitir aquele que aguardou o início das investigações para se apresentar à autoridade um tratamento mais benéfico que aquele conferido a quem (i) delatou e confessou a prática; e (ii) cooperou de forma plena com as investigações.

Nas demais hipóteses, a questão da importância do reconhecimento de participação na prática merece exame cuidadoso. A preocupação é não apenas com o caso particular, mas em preservar os incentivos para a detecção de novas práticas por meio de Acordo de Leniência, dissuadir condutas colusivas,

\footnotetext{
550 JOÃo BOSCO LEOPOLDINO DA FONSECA já apontava as únicas vantagens do agente econômico na celebração do Termo de Compromisso de Cessação, dentre elas, a prescindibilidade da confissão: “Por outro lado, por parte do agente econômico, não interessa empenhar o seu tempo de atividade empresarial em processos de desfecho incerto e, acima de tudo, de longa duração. É economicamente mais vantajoso para a empresa não alimentar uma situação de dúvida sobre a lisura de sua conduta no mercado.

Para atingir esse objetivo comum, o legislador fixa um parâmetro aceitável bilateralmente: o agente econômico cessa a prática dos atos que a Administração entende lesivos e, por outro lado, essa cessação não equivale à confissão nem a reconhecimento de ilicitude da conduta que está sendo objeto de investigação.” (FONSECA, João Bosco Leopoldino da. Lei de proteção da concorrência: comentários à legislação antitruste. P. 328).
} 
além de se não permitir que membros de cartéis se furtem de suas responsabilidades nas áreas privadas e criminais." ${ }^{, 51}$

É indiscutível para as autoridades antitruste a obrigatoriedade da confissão nos Termos de Compromisso de Cessação de Prática, sob o principal pretexto de se preservar o acordo de leniência. Isso porque, no seu entender,

\footnotetext{
“[...] somente há incentivos para a procura pelo Programa de Leniência se (i) a probabilidade de detecção por parte da autoridade for alta; (ii) se há perspectiva de punição severa; e (iii) não houver perspectiva de alternativa mais vantajosa caso o cartel seja detectado, o que só ocorrerá se o TCC for celebrado em termos severos. ${ }^{\text {} 52}$
}

Em sua cartilha Política da SDE - Termo de Compromisso de Cessação de Prática em Cartel, a Secretaria de Direito Econômico apresenta os critérios que deverão ser considerados para a emissão de pareceres a respeito de propostas de Termos de Compromisso de Cessação de Prática. São eles:

“(i) as propostas de TCC de pessoas jurídicas e pessoas físicas em casos de investigações de cartéis com Acordo de Leniência devem conter, ao menos: (a) confissão de participação na prática ao menos nos mesmos termos daqueles do beneficiário do Acordo de Leniência; (b) reconhecimento da legalidade da diligência de busca e apreensão (se aplicável); (c) obrigação de cooperação ativa na investigação (e não meramente técnica); (d) contribuição pecuniária em valor que garanta efeito dissuasório; e (e) não criação de obstáculos à persecução criminal e ações privadas de indenização.

(ii) as propostas de TCC de pessoas jurídicas em casos de investigações de cartéis clássicos com prova direta e sem Acordo de Leniência devem conter, ao menos: (a) reconhecimento de participação na prática; (b) reconhecimento da legalidade da diligência de busca e apreensão (se aplicável); (c) obrigação de cooperação ativa na investigação (e não meramente técnica); (d) contribuição pecuniária em valor que garanta efeito

\footnotetext{
${ }^{551}$ BRASIL. MINISTÉRIO DA JUSTIÇA. CADE. Política da SDE - Termo de Compromisso de Cessação de prática em cartel. P. 03.

${ }^{552}$ Idem, ibidem.
} 
dissuasório; e (e) não criação de obstáculos à persecução criminal e ações privadas de indenização.

(iii) as propostas de TCC de pessoas físicas em casos de investigações de cartéis clássicos com prova direta e sem Acordo de Leniência devem conter, ao menos: (a) reconhecimento da legalidade da diligência de busca e apreensão (se aplicável); (b) obrigação de cooperação na investigação; (c) contribuição pecuniária em valor que garanta efeito dissuasório; e (d) não criação de obstáculos à persecução criminal e ações privadas de indenização; (iv) as propostas de TCC de pessoas jurídicas e pessoas físicas em casos de investigações de cartéis difusos e sem Acordo de Leniência devem conter, ao menos: (a) reconhecimento da legalidade da diligência de busca e apreensão (se aplicável); (b) contribuição pecuniária em valor que garanta efeito dissuasório; e (c) não criação de obstáculos à persecução criminal e ações privadas de indenização." 553 (grifos no original)

À vista dos critérios apresentados, algumas considerações tornam-se necessárias. Primeiramente, vale observar o tratamento diferenciado conferido pelas autoridades antitruste às condutas de alto potencial danoso (cartéis clássicos) e aquelas menos prejudiciais (cartéis difusos). Os clássicos, considerados pela OCDE o mais grave ilícito anticoncorrencial, ${ }^{54}$ seriam

$$
\begin{aligned}
& \text { “[...] acordos secretos entre competidores com alguma forma de } \\
& \text { institucionalidade, com objetivo de fixar preços e condições de venda, dividir } \\
& \text { consumidores, definir nível de produção (...), [cuja] ação não decorre de uma } \\
& \text { situação eventual de coordenação, mas da construção de mecanismos } \\
& \text { permanentes para alcançar seus objetivos." } 555
\end{aligned}
$$

Os cartéis difusos são definidos pelo CADE como "[...] um ato de coordenação da ação entre empresas com objetivo similar ao do Cartel Clássico, mas de caráter eventual e não institucionalizado. ${ }^{, 556}$ Para efeitos penais, não subsiste tal distinção, porque é ínsito da

\footnotetext{
553 BRASIL. MINISTÉrio DA JUSTIÇA. CADE. Política da SDE - Termo de Compromisso de Cessação de prática em cartel. P. 09.

${ }^{554} \mathrm{Cf}$. OCDE. 1998 OECD recommendation of the council concerning effective action against hard core cartels.

555 Conceito extraído do trecho do voto do Conselheiro-Relator Luiz Carlos Delorme Prado proferido no julgamento do Processo Administrativo no ${ }^{\circ}$.08012.002127/2002-14, Cartel das Britas.

${ }^{556}$ Idem.
} 
definição do cartel o elemento estabilidade, sendo incompatível com esta conduta a expressão eventualidade. Figura como elemento do tipo penal do cartel a estabilidade ou a permanência, o que torna questionável a expressão "cartel difuso" utilizada pelas autoridades antitruste. ${ }^{557}$

Uma segunda crítica guarda relação com a contradição existente entre a Lei $n^{\circ}$ 11.482/2007 e a Resolução no 46/2007 editada pelo CADE. A lei não distinguiu a possibilidade de celebração de Termo de Compromisso de Cessação de Prática quando presente ou ausente o acordo de leniência. Já o ato normativo vetou referido mecanismo de solução de procedimento administrativo nos casos em que houver leniência, salvo se reconhecida a culpa. É nítida, pois, a contrariedade entre o disposto na Resolução e na Lei, havendo clara afronta à hierarquia das normas.

Uma outra falha da regulamentação do instituto diz respeito à exigência da confissão. De acordo com a política da Secretaria de Direito Econômico, nos cartéis clássicos é imprescindível a confissão da participação no delito. Mas, por que exigir a confissão em um termo bilateral de mediação ${ }^{558}$

Evidentemente, não há vantagem alguma para o suposto infrator em firmar um ajuste que o leve diretamente para as agruras de um processo penal, pois a confissão da prática do crime de cartel seria extremamente oportuna para promotores e procuradores oferecerem, de imediato, uma ação penal em face do candidato.

Se a intenção da Secretaria de Direito Econômico consiste em atrair novos candidatos à celebração de mais Termos de Compromisso de Cessação de Prática, é contraditório deles exigir o reconhecimento da culpa pela prática da infração anticoncorrencial. No âmbito penal, a insegurança jurídica para o envolvido é de tal monta que todas as possíveis vantagens que lhe são oferecidas na esfera administrativa passam a ser insignificantes. Não há garantia alguma que aquela prova produzida contra si não será utilizada a seu desfavor.

Importante consignar que o reconhecimento da culpa no ilícito é exigido quando presente o acordo de leniência e em casos de propostas de pessoas físicas envolvidas em

\footnotetext{
${ }^{557}$ FERRARI, Eduardo Reale. Termos de Compromisso de Cessação (TCC) e seus reflexos no crime de cartel. Pp. 09/10.

${ }^{558}$ Idem, ibidem, p. 09.
} 
cartéis clássicos sem a sua a celebração, ${ }^{559}$ o que torna inócua a alegação no sentido de haver necessidade de conferir um ônus mais gravoso ao compromissário do que ao leniente. ${ }^{560}$

Acerca desta exigência específica, assim se pronunciou EDUARDO REALE FERRARI:

\begin{abstract}
“Ao nosso ver, imprópria é a exigência por meio do termo 'confissão' ou ‘participação na prática do fato' como requisito para qualquer condição para a assinatura do TCC, colocando em xeque a própria eficácia do relevantíssimo instituto do TCC, vez que ao condicionar a sua aceitação ao reconhecimento da existência e participação dos fatos considerados como prática de cartel, em face da absurda independência criminal e administrativa, difícil se torna à resolução dos conflitos, por meio da mediação, não podendo abrir-se mão de tão importante instituto, sob pena de indefinido procedimento administrativo, assim como de inúmeros e morosos questionamentos jurisdicionais, devendo se fomentar a resolução do conflito de forma bilateral, com base na lei e preferencialmente fora do âmbito jurisdicional já tão atolado de processos administrativos.

A introdução do conceito do termo 'confissão', aliás, ao que parece, foi uma clara importação da ICN [International Competition Network], a qual considera o reconhecimento de culpa como requisito chave para a celebração de TCCs, já que segundo a ICN o reconhecimento (de culpa ou de participação), na prática forçaria outros participantes do cartel a considerar fazer o mesmo, além de dar notícia ao público e às vítimas do cartel a respeito da conduta ilícita na qual o investigado reconheceria sua participação."561
\end{abstract}

Uma outra curiosa exigência da Secretaria de Direito Econômico presente em todos os casos (itens $i$ a $i v$ da Cartilha Política da SDE - Termo de Compromisso de Cessação de Prática em Cartel) é o reconhecimento da legalidade da diligência de busca e apreensão, se aplicável à hipótese. A respeito do tema, EDUARDO REALE FERRARI bem advertiu que

\footnotetext{
${ }^{559}$ Neste caso, a exigência da confissão vem revestida da expressão "reconhecimento de participação na prática".

${ }^{560}$ Conforme já mencionado, segundo a Política da Secretaria de Direito Econômico, "Por motivos óbvios, não se quer permitir aquele que aguardou o início das investigações para se apresentar à autoridade um tratamento mais benéfico que aquele conferido a quem (i) delatou e confessou a prática; e (ii) cooperou de forma plena com as investigações". (BRASIL. MINISTÉRIO DA JUSTIÇA. CADE. Política da SDE Termo de Compromisso de Cessação de prática em cartel. P. 02).

${ }^{561}$ FERRARI, Eduardo Reale. Termos de Compromisso de Cessação (TCC) e seus reflexos no crime de cartel. P. 09.
} 


\begin{abstract}
"Se a busca e apreensão dependem de autorização judicial por que a necessidade da legitimidade da empresa e/ou empresário? Já não seria lícita em face da autorização judicial? Será que tal sugestão tem a intenção em evitar o questionamento jurisdicional e consequentemente ignorar o artigo $5^{\circ}$, inciso XXXV da CF, que confere a qualquer pessoa o acesso ao Poder Judiciário no caso de lesão ou ameaça de lesão a direito?"562
\end{abstract}

De igual modo apresenta-se a condição presente em todas as situações expostas na Cartilha, qual seja, a "[...] não criação de obstáculos à persecução criminal e ações privadas de indenização." O que pretenderam as autoridades antitruste ao preverem tal exigência? No que consistem os obstáculos à persecução penal e às ações privadas?

Ao que parece, tais previsões têm o condão de eliminar as armas processuais defensivas que detêm o compromissário. O requisito que impossibilita o suposto infrator de discutir judicialmente uma persecução penal ou uma ação cível de indenização fere de morte as garantias constitucionais da ampla defesa do contraditório e, sobretudo, do devido processo legal (artigo 5º LIV e LV, da Carta Magna).

A despeito da seriedade de todas as críticas, conclui-se que a grande problemática do Termo de Compromisso de Cessação de Prática gira em torno da exigência da confissão para a celebração do ajuste.

Em sua defesa, a Secretaria de Direito Econômico ressalta o que segue:

\footnotetext{
"A Rede Internacional da Concorrência (International Competition Network - ICN) emitiu em 2008 relatório sobre 'Acordos em Casos de Cartéis' (Cartel Settlements'), no qual considera o reconhecimento de culpa ou ao menos dos fatos investigados pela autoridade como o primeiro requisito-chave para a celebração de TCCs (em suas palavras: 'Um acordo em caso de cartel deve ao menos descrever a conduta do cartel em questão. As jurisdições diferenciam-se, contudo, se o signatário deve reconhecer culpa elou reconhecer os fatos que embasam a conduta de cartel sob investigação'). Ainda sobre a importância do reconhecimento de culpa ou dos fatos, a ICN destaca:
}

${ }^{562}$ Idem, ibidem, p. 09. 
Referido reconhecimento [de culpa ou de participação na prática] força outros participantes do cartel a considerar fazer o mesmo, além de dar notícia ao público e às vítimas do cartel a respeito da conduta ilícita na qual o investigado reconheceu sua participação. Da mesma forma, um acordo que não contém um reconhecimento de culpa ou dos fatos relacionados ao cartel pode reduzir o efeito dissuasório da investigação e pode ainda provocar uma percepção pública negativa em relação aos acordos. Acordos celebrados sem o reconhecimento de culpa podem gerar a percepção por parte do público em geral e da comunidade empresarial de que a prática de cartel é uma mera infração de baixo potencial lesivo e de que a decisão da empresa de celebrar o acordo foi a forma encontrada para ela se 'livrar de um incômodo' que não merecia o tempo e os recursos do litígio. Várias jurisdições também destacaram que a política de exigir reconhecimento de culpa é consistente com o sentimento universal de que cartéis são a mais severa e grave violação à legislação de defesa da concorrência. " ${ }^{563}$ (grifos no original)

Como se vê, houve uma clara importação de conceitos do International Competition Network-ICN para a regulamentação do nosso Termo de Compromisso de Cessação de Prática. Contudo, em nosso ordenamento jurídico, referido instituto provoca reflexos diretos no âmbito penal, de maneira que a simples importação de fórmulas adotadas em outras jurisdições não se adequa, de pronto, ao nosso Direito Penal. ${ }^{564}$

Não pairam dúvidas acerca da pertinência da preocupação dos órgãos antitruste brasileiros com o (des)estímulo ao Programa de Leniência de acordo com as condições estabelecidas para o Termo de Compromisso de Cessação de Prática. A existência de um

\footnotetext{
563 BRASIL. MINISTÉRIO DA JUSTIÇA. CADE. Política da SDE - Termo de Compromisso de Cessação de prática em cartel. Pp. 06/07.

${ }^{564}$ Sobre a importação de conceitos da legislação internacional, PEDRO VICENTINI explana: "Conforme bem destaca o Conselheiro Prado, a tendência da SDE em exigir um modelo único de TCC, com confissão de culpa, surge em grande parte da comparação equivocada do instrumento brasileiro a outros instrumentos disponíveis na legislação internacional, sobretudo os plea agreements. (...) Basicamente, existem duas espécies de acordo estudadas atualmente no âmbito da ICN (International Competition Network) e da OCDE, a saber os plea agreements, em que a confissão de culpa faz parte da natureza do acordo, e os settlement agreement, em que a culpa não é essencial à sua celebração. A origem destas duas espécies de acordo vem essencialmente do direito norte-americano, respectivamente, no plea bargain $e$ no consent decree. (...) Diferentemente do que se passa no Brasil, os órgãos antitruste norte-americanos são responsáveis tanto pela persecução cível dos danos causados pelas infrações antitruste, tanto pela persecução criminal decorrentes das práticas anticompetitivas que também constituam crime, Não existem três esferas independentes (administrativa, penal e civil) da maneira como ocorre no Brasil, sendo certo que compete ao Poder Judiciário norte-americano decidir em último instância pela existência ou não de infração à ordem econômica." (VICENTINI, Pedro. Op. cit., pp. 265/266).
} 
instituto de forma alguma deve prejudicar o sucesso do outro, ao contrário, pretende-se a soma de esforços para um amplo combate às práticas anticoncorrenciais.

Entretanto, julga-se desnecessária a previsão do reconhecimento da culpa, em qualquer "tipo" de cartel - seja ele clássico, seja difuso -, sob pena de se condenar a existência do instituto. ${ }^{565}$ Entende-se ser concebível a substituição da expressão "confissão" por "colaboração", quer por parte do leniente, quer via qualquer outra pessoa jurídica ou física envolvida nos fatos apurados mediante processo administrativo; não se descarta a importância de alguma contribuição para as autoridades antitruste como forma de contraprestação na mediação bilateral em que consiste o Termo de Compromisso de Cessação de Prática.

De fato, esse é

“[...] um passo importante para uma maior aproximação entre as esferas penal e administrativa, no âmbito da temática antitruste, e destacando que quanto ao obstáculo do revanchismo contra o leniente já há previsão no TCC acerca da impossibilidade de se proporem ações de indenização contra o mesmo."

É irrefragável que a total ausência de normativa de dependência entre as esferas administrativa e penal direciona a confissão contra o próprio confesso na seara penal, desencorajando os candidatos à mediação.

Vale mencionar que

“[...] o instrumental da mediação do TCC pode ser uma das melhores vias de resolução do conflito em um Direito Administrativo Sancionador, não havendo dúvida de que a ausência de norma de dependência entre os órgãos administrativos e criminais permeia o acordo no instante da decisão por assinar ou não um TCC na área administrativa."

\footnotetext{
${ }^{565}$ CARLA LOBÃO alerta que "Visões como as aqui registradas, em que a tônica maior é a repressão, sinalizam conceitos equivocados com relação ao instituto do compromisso de cessação e limitações à sua aplicação, bem como se prestam a desestimular o representado a buscar o compromisso, a despeito dos inegáveis benefícios que a lei lhe assegura." (LOBÃO, Carla. Op. cit., p. 98).

${ }^{566}$ FERRARI, Eduardo Reale. Termos de Compromisso de Cessação (TCC) e seus reflexos no crime de cartel. P. 10.

${ }^{567}$ Idem, ibidem, p. 09.
} 
Daí a relevância da análise do Programa de Leniência sob esse enfoque.

A reflexão sobre a adequação das condições dos mecanismos de solução alternativa de procedimento administrativo decorre do fato de que no Brasil aproximadamente quatro Termos de Compromisso de Cessação de Prática foram firmados em casos originários de acordo de leniência. ${ }^{568}$ É preponderante a reformulação das exigências contidas na Resolução no 46/07, preservando-se, de um lado, a tutela do Programa de Leniência e, de outro, a segurança jurídica do proponente. ${ }^{569}$

\subsection{Propostas Legislativas e a Recém-Aprovada Lei $n^{\circ}$ 12.529, de 30 de Novembro de 2011}

A fim de aprimorar e desenvolver o Sistema Brasileiro de Defesa da Concorrência, na esteira das mais modernas legislações estrangeiras e em observância às necessidades específicas do mercado nacional, o nosso Poder Legislativo propôs uma série de Projetos de Lei acerca do assunto e, recentemente, logrou êxito em promulgar a Lei no 12.529/11.

Dentre as últimas proposições que merecem destaque está o Projeto de Lei $n^{\circ}$ 3.937/2004, de relatoria do deputado CARLOS EDUARDO CADOCA, que “[...] altera a Lei $n^{\circ}$ 8.884/94, que transforma o CADE em autarquia, dispõe sobre a prevenção e a repressão às infrações contra a ordem econômica e dá outras providências." Tal projeto altera os artigos 20, 24, 26 e 54 da Lei $n^{\circ}$ 8.884/94, sem abordar, todavia, o instituto da leniência, mantendo a redação original conferida pela Lei $n^{\circ} 10.149 / 00$. Já o Projeto de Lei $n^{\circ}$ 5.877/2005, de autoria do Poder Executivo, “[...] estrutura o Sistema Brasileiro de Defesa da Concorrência e dispõe sobre a prevenção e repressão às infrações contra a ordem econômica e dá outras providências." 570

\footnotetext{
${ }^{568}$ Dados obtidos no sítio eletrônico da Secretaria de Direito Econômico.

${ }^{569}$ Importa registrar que a recém-publicada Lei $n^{\circ} 12.529 / 11$, que revoga e modifica a atual Lei de Defesa de Concorrência, não trouxe alterações significativas com relação ao Termo de Compromisso de Cessação de Prática sob os aspectos abordados no presente subitem, de modo que o novo dispositivo que regulamenta o instituto não será abordado (artigo 85). Entretanto, vale destacar que a nova regulamentação do Termo de Compromisso de Cessação de Prática não traz a exigência da confissão para a celebração do Termo de Compromisso de Cessação. Por outro lado, em seu artigo 85, § 14, prevê que "O Cade definirá, em resolução, normas complementares sobre o termo de compromisso de cessação." Ou seja, sem solucionar o impasse, atribui ao CADE a definição das obrigações e requisitos para a mediação.

${ }^{570}$ Disponível em <http://www.camara.gov.br/sileg/Prop_Detalhe.asp?id=299747>. Acesso em 3 de março de 2010 .
} 
Referida proposição reformula toda a legislação antitruste brasileira, alterando grande parte dos artigos da Lei $\mathrm{n}^{\circ} 8.884 / 94$, inclusive aqueles que dispõem acerca do acordo de leniência. ${ }^{571}$

\section{1 “CAPÍTULO VII \\ DO PROGRAMA DE LENIÊNCIA}

[...] Art. 87. O CADE, por intermédio da Superintendência-Geral, poderá celebrar acordo de leniência, com a extinção da ação punitiva da administração pública ou a redução de um a dois terços da penalidade aplicável, nos termos deste artigo, com pessoas físicas e jurídicas que forem autoras de infração à ordem econômica, desde que colaborem efetivamente com as investigações e o processo administrativo e que dessa colaboração resulte:

I - a identificação dos demais envolvidos na infração; $e$

II - a obtenção de informaçães e documentos que comprovem a infração noticiada ou sob investigação.

$\S 1^{\circ} \mathrm{O}$ disposto neste artigo não se aplica às empresas ou pessoas físicas que tenham estado à frente da conduta tida como infracionária.

$\S 2^{\circ} O$ acordo de que trata o caput deste artigo somente poderá ser celebrado se preenchidos, cumulativamente, os seguintes requisitos:

I - a empresa ou pessoa física seja a primeira a se qualificar com respeito à infração noticiada ou sob investigação;

II - a empresa ou pessoa física cesse completamente seu envolvimento na infração noticiada ou sob investigação a partir da data de propositura do acordo;

III - a Superintendência-Geral não disponha de provas suficientes para assegurar a condenação da empresa ou pessoa física quando da propositura do acordo; $e$

IV - a empresa ou pessoa física confesse sua participação no ilícito e coopere plena e permanentemente com as investigações e o processo administrativo, comparecendo, sob suas expensas, sempre que solicitada, a todos os atos processuais, até seu encerramento.

$\S 3^{\circ} \mathrm{O}$ acordo de leniência firmado com o CADE, por intermédio da Superintendência-Geral, estipulará as condições necessárias para assegurar a efetividade da colaboração e o resultado útil do processo.

$\S 4^{\circ}$ Compete ao Tribunal, quando do julgamento do processo administrativo, verificado o cumprimento do acordo:

I - decretar a extinção da ação punitiva da administração pública em favor do infrator, nas hipóteses em que a proposta de acordo tiver sido apresentada à Superintendência-Geral sem que essa tivesse conhecimento prévio da infração noticiada; ou

II - nas demais hipóteses, reduzir de um a dois terços as penas aplicáveis, observado o disposto no art. 40, devendo ainda considerar na gradação da pena a efetividade da colaboração prestada e a boa-fé do infrator no cumprimento do acordo de leniência.

$\S 5^{\circ}$ Na hipótese do inciso II do $\$ 40$, a pena sobre a qual incidirá o fator redutor não será superior à menor das penas aplicadas aos demais co-autores da infração, relativamente aos percentuais fixados para a aplicação das multas de que trata o art. 33 desta Lei.

$\S 6^{\circ}$ Serão estendidos às empresas do mesmo grupo, de fato ou de direito, e aos seus dirigentes, administradores e empregados envolvidos na infração, os efeitos do acordo de leniência, desde que o firmem em conjunto, respeitadas as condições impostas.

$\S 7^{\circ}$ A empresa ou pessoa física que não obtiver, no curso de inquérito ou processo administrativo, habilitação para a celebração do acordo de que trata este artigo, poderá celebrar com a SuperintendênciaGeral, até a remessa do processo para julgamento, acordo de leniência relacionado a uma outra infração, da qual o CADE não tenha qualquer conhecimento prévio.

$\S 8^{\circ} \mathrm{Na}$ hipótese do $\S 7^{\circ}$, o infrator se beneficiará da redução de um terço da pena que lhe for aplicável naquele processo, sem prejuizo da obtenção dos benefícios de que trata o inciso I do §4o deste artigo em relação à nova infração denunciada.

$\S 9^{\circ}$ Considera-se sigilosa a proposta de acordo de que trata este artigo, salvo no interesse das investigações e do processo administrativo.

\$ 10. Não importará em confissão quanto à matéria de fato, nem reconhecimento de ilicitude da conduta analisada, a proposta de acordo de leniência rejeitada, da qual não se fará qualquer divulgação.

$\S 11$. A aplicação do disposto neste artigo observará as normas a serem editadas pelo Tribunal.

Art. 88. Nos crimes contra a ordem econômica, tipificados na Lei $n^{\circ}$ 8.137, de 27 de dezembro de 1990, a celebração de acordo de leniência, nos termos desta Lei, determina a suspensão do curso do prazo prescricional e impede o oferecimento da denúncia. 
Ainda que o projeto de lei traga inúmeras alterações estruturais ao Sistema Brasileiro de Defesa de Concorrência, deixa a desejar quanto às alterações referentes ao acordo de "abrandamento".

A primeira alteração a se destacar diz respeito a um simples aspecto formal, adequando o instituto à nova estrutura organizacional do CADE. O acordo de leniência não mais é firmado pela Secretaria de Direito Econômico, que não mais existirá, mas pela Superintendência-Geral do CADE. Da mesma forma, modifica-se o órgão competente para a verificação do cumprimento do acordo, passando a ser atribuição do chamado Tribunal do CADE.

A última alteração é trazida pelo $\S 6^{\circ}$, do artigo 87 , do Projeto de Lei, segundo o qual

“[...] serão estendidos às empresas do mesmo grupo, de fato ou de direito, e aos seus dirigentes, administradores e empregados envolvidos na infração, os efeitos do acordo de leniência, desde que o firmem em conjunto, respeitadas as condições impostas."

Note-se que, nos termos da Lei $n^{\circ} 8.884 / 94$, os efeitos do acordo serão estendidos apenas aos dirigentes e administradores da empresa habilitada.

Já o Projeto de Lei no 3.434/2008, seguindo as avançadas legislações estrangeiras sobre o tema, "[...] altera o artigo 35-B da Lei $n^{o}$ 8.884/94, de modo a autorizar a realização de acordos de leniência com pessoas que venham a colaborar efetivamente com investigações destinadas a apurar infrações contra a ordem econômica." 572

Parágrafo único. Cumprido o acordo de leniência pelo agente, extingue-se automaticamente a punibilidade dos crimes a que se refere o caput deste artigo." (grifos nossos)

572 “[...] Art. $2^{\circ}$. O artigo 35-B da Lei $n^{\circ}$ 8.884, de 1994, passa a vigorar com as seguintes alterações: Art. 35 (...)

$\S 2^{o}$ O acordo de que trata o caput deste artigo somente poderá ser celebrado se preenchidos, cumulativamente, os seguintes requisitos:

I - a empresa seja a primeira a se qualificar com respeito à infração noticiada ou sob investigação;

II - a pessoa física seja a primeira a se qualificar com respeito à infração noticiada ou sob investigação ou, não sendo a primeira, traga fatos novos importantes para identificar outros co-autores;

III - a empresa ou pessoa física cesse completamente seu envolvimento na infração noticiada ou sob investigação a partir da data da propositura do acordo;

$I V$ - a SDE não disponha de provas suficientes para assegurar a condenação da empresa ou pessoa física quando da propositura do acordo; 
O deputado CARlos BezerRA, ao justificar o projeto de lei de sua autoria, asseverou que

“[...] o objetivo da presente proposta é aprimorar o instituto da delação premiada, permitindo que outras pessoas físicas, além da primeira a delatar a infração, possam vir a ser beneficiadas com a redução da pena, desde que as novas informações prestadas venham, de fato, a contribuir para a identificação de novos co-autores ou novas infrações."

O autor destacou, ainda, que “[...] com essa medida, esperamos possibilitar aos demais diretores de empresas o incentivo da delação premiada para denunciar os integrantes do cartel, o que, certamente, facilitará o trabalho das autoridades administrativas.”

Bem posicionou-se o deputado ao propor essa mudança na Lei de Defesa da Concorrência, possibilitando aos demais candidatos à leniência, e não só ao primeiro, os benefícios decorrentes do acordo, em troca das tão almejadas provas - informações e documentos - da prática da conduta ilícita. Não seria incomum se outros, que não o primeiro delator, possuíssem informações de extrema valia para a autoridade antitruste, uma vez que se parte da premissa que todos participaram efetiva e ativamente do cartel.

Aliás, o referido projeto de lei, além de estar em consonância com a legislação antitruste da União Europeia, seguiu orientação há muito delineada pela mais abalizada doutrina:

\footnotetext{
"Do ponto de vista estrutural o programa em muito avançaria se fosse estudada proposta de reforma legislativa que (i) possibilitasse a outros, além do primeiro a delatar, o benefício de redução da pena, a exemplo do ocorrido na União Européia e como recomendado pela International Competition
}

$V$ - a empresa ou pessoa física confesse sua participação no ilícito e coopere plena e permanentemente com as investigações e o processo administrativo, comparecendo, sob suas expensas, sempre que solicitada, a todos os atos processuais, até seu encerramento.

(...). $”$

(Disponível em <http://www.camara.gov.br/sileg/Prop_Detalhe.asp?id=395735>. Acesso em 3 de março de 2010). 
Network. Essa faculdade deve estar disponível, se não para as pessoas jurídicas, ao menos para as pessoas físicas, como diretores da empresa."

Ao considerar a semelhança de matéria, assim como de algumas propostas, todos os três projetos de lei apresentados passaram a tramitar em conjunto. Em 28 de outubro de 2005, apensou-se o Projeto de Lei $\mathrm{n}^{\mathrm{o}} 5.877 / 2005$ ao de $\mathrm{n}^{\mathrm{o}} 3.937 / 2004$ e, em 27 de maio de 2008, apensou-se o Projeto de Lei no 3.434/2008 ao de $n^{\circ} 5.877 / 2005$.

Ao final de 2008, estes Projetos foram julgados prejudicados pela Câmara dos Deputados, criando-se um outro mais completo e substitutivo ao de $\mathrm{n}^{\circ} 3.937 / 2004$. Em 17 de dezembro do mesmo ano, o Plenário desta Casa Legislativa encaminhou o texto aprovado ao Senado Federal. Passou a tramitar neste órgão o Projeto de Lei no 06/2009, aprovado em dezembro de 2010 pelos seus membros, e em 5 de outubro de 2011 pela Câmara dos Deputados.

Ao enfatizar a relevância de suas disposições, bem como a urgência de sua apreciação, o relatório da OCDE Lei e Política de Concorrência no Brasil - uma revisão pelos pares, elaborado em 2010, assim estabeleceu:

"Há vários anos, tramita no Congresso Nacional brasileiro um projeto de lei de defesa da concorrência abrangente (PL 06/2009), que revisaria amplamente o SBDC e resolveria muitos dos problemas que há muito o atingem. A consideração desse projeto de lei foi postergada por diversas vezes mas, como mencionado anteriormente, à época da elaboração deste relatório havia um forte ímpeto para sua aprovação. O Presidente da República o defendeu veementemente; a comunidade empresarial, que no passado havia demonstrado reservas quanto a alguns de seus aspectos, especialmente acerca da notificação prévia de atos de concentração, declarou apoio à legislação. $\mathrm{O}$ projeto teve apoio efetivo em ambas as casas do Congresso Nacional, e os proponentes estão otimistas sobre sua eventual aprovação. Ainda assim, a tramitação no Congresso continua em andamento; há urgência para se completar esse esforço no primeiro semestre de 2010; caso contrário, as eleições nacionais previstas para o final do ano postergariam novamente a aprovação do projeto de lei. A legislação foi aprovada na Câmara dos

${ }^{573}$ RODAS, João Grandino. Acordos de leniência em direito concorrencial: práticas e recomendações. P. 32. Na mesma linha, International Competition Network, Drafting and Implementing an Effective Leniency Program. P. 8 (2006). 
Deputados e está sendo debatida no Senado. Algumas emendas foram propostas no Senado, que se aceitas exigiriam sua submissão à Câmara dos Deputados." $" 574$

A propósito, o projeto de lei foi rapidamente sancionado pela presidenta da República e, em 30 de novembro de 2011, foi publicada a Lei $\mathrm{n}^{\circ}$ 12.529/11. A novel legislação traz algumas modificações benéficas à nossa Lei Antitruste, tangenciando a atual regulamentação do instituto da leniência. ${ }^{575}$

\footnotetext{
${ }^{574}$ OCDE. Lei e política de concorrência no Brasil: uma revisão pelos pares -2010.

575 “CAPÍTULO VII
}

DO PROGRAMA DE LENIÊNCIA

[...] Art. 86. O Cade, por intermédio da Superintendência-Geral, poderá celebrar acordo de leniência, com a extinção da ação punitiva da administração pública ou a redução de 1 (um) a 2/3 (dois terços) da penalidade aplicável, nos termos deste artigo, com pessoas físicas e jurídicas que forem autoras de infração à ordem econômica, desde que colaborem efetivamente com as investigações e o processo administrativo e que dessa colaboração resulte:

I - a identificação dos demais envolvidos na infração; $e$

II - a obtenção de informações e documentos que comprovem a infração noticiada ou sob investigação.

$\S 1^{o} \mathrm{O}$ acordo de que trata o caput deste artigo somente poderá ser celebrado se preenchidos, cumulativamente, os seguintes requisitos:

I - a empresa seja a primeira a se qualificar com respeito à infração noticiada ou sob investigação;

II - a empresa cesse completamente seu envolvimento na infração noticiada ou sob investigação a partir da data de propositura do acordo;

III - a Superintendência-Geral não disponha de provas suficientes para assegurar a condenação da empresa ou pessoa física por ocasião da propositura do acordo; $e$

IV - a empresa confesse sua participação no ilícito e coopere plena e permanentemente com as investigações e o processo administrativo, comparecendo, sob suas expensas, sempre que solicitada, a todos os atos processuais, até seu encerramento.

$\S 2^{\circ}$ Com relação às pessoas físicas, elas poderão celebrar acordos de leniência desde que cumpridos os requisitos II, III e IV do $\$ 1^{\circ}$ deste artigo.

$\S 3^{\circ} \mathrm{O}$ acordo de leniência firmado com o Cade, por intermédio da Superintendência-Geral, estipulará as condições necessárias para assegurar a efetividade da colaboração e o resultado útil do processo.

$\S 4^{o}$ Compete ao Tribunal, por ocasião do julgamento do processo administrativo, verificado o cumprimento do acordo:

I - decretar a extinção da ação punitiva da administração pública em favor do infrator, nas hipóteses em que a proposta de acordo tiver sido apresentada à Superintendência-Geral sem que essa tivesse conhecimento prévio da infração noticiada; ou

II - nas demais hipóteses, reduzir de 1 (um) a 2/3 (dois terços) as penas aplicáveis, observado o disposto no art. 45 desta Lei, devendo ainda considerar na gradação da pena a efetividade da colaboração prestada e a boa-fé do infrator no cumprimento do acordo de leniência.

$\S 5^{\circ} \mathrm{Na}$ hipótese do inciso II do $\S 4^{\circ}$ deste artigo, a pena sobre a qual incidirá o fator redutor não será superior à menor das penas aplicadas aos demais coautores da infração, relativamente aos percentuais fixados para a aplicação das multas de que trata o inciso I do art. 37 desta Lei.

$\$ 6^{\circ}$ Serão estendidos às empresas do mesmo grupo, de fato ou de direito, e aos seus dirigentes, administradores e empregados envolvidos na infração os efeitos do acordo de leniência, desde que o firmem em conjunto, respeitadas as condições impostas.

$\S 7^{\circ}$ A empresa ou pessoa física que não obtiver, no curso de inquérito ou processo administrativo, habilitação para a celebração do acordo de que trata este artigo, poderá celebrar com a SuperintendênciaGeral, até a remessa do processo para julgamento, acordo de leniência relacionado a uma outra infração, da qual o Cade não tenha qualquer conhecimento prévio. 
De início, observa-se que é mantida a alteração trazida pelo Projeto de Lei $n^{\circ}$ 5.877/2005 no que concerne à autoridade competente para a celebração do acordo, qual seja, a Superintendência-Geral do CADE. Igualmente, é mantida a atribuição do Tribunal do CADE de verificar o cumprimento do acordo.

A segunda alteração segue proposta já apresentada pelo Projeto de Lei $n^{\circ}$ 3.434/2008, permitindo que não só o primeiro delator participe do acordo, mas outros que possam contribuir de modo efetivo com as investigações das autoridades antitruste, recebendo em troca os benefícios nas esferas penal e administrativa.

Sem dúvida, os legisladores inseriram acertadamente esta modificação, uma vez que é de grande interesse dos órgãos de defesa da concorrência a obtenção de provas, em quantidade e qualidade, a respeito de condutas anticompetitivas. Como há imensa dificuldade em obtê-las, ao se tratar, sobretudo, de cartéis, a legislação deve possibilitar a um maior número de interessados participar do acordo, auxiliando diretamente na descoberta das infrações e de seus autores.

É conveniente que se atente ao fato de inexistir na nova lei a gradação nos benefícios concedidos aos lenientes. A exemplo da legislação da União Europeia, mais de um candidato à leniência deve receber redução na penalidade, e não imunidade total, porém é preciso seguir uma ordem decrescente nessa diminuição, do primeiro ao último leniente, de maneira a privilegiar os primeiros interessados em auxiliar as autoridades.

$\S 8^{\circ} \mathrm{Na}$ hipótese do $\S 7^{\circ}$ deste artigo, o infrator se beneficiará da redução de $1 / 3$ (um terço) da pena que lhe for aplicável naquele processo, sem prejuízo da obtenção dos benefícios de que trata o inciso I do $\$ 4^{o}$ deste artigo em relação à nova infração denunciada.

$\S 9^{\circ}$ Considera-se sigilosa a proposta de acordo de que trata este artigo, salvo no interesse das investigações e do processo administrativo.

$\S 10$. Não importará em confissão quanto à matéria de fato, nem reconhecimento de ilicitude da conduta analisada, a proposta de acordo de leniência rejeitada, da qual não se fará qualquer divulgação.

$\$ 11$. A aplicação do disposto neste artigo observará as normas a serem editadas pelo Tribunal.

\$12. Em caso de descumprimento do acordo de leniência, o beneficiário ficará impedido de celebrar novo acordo de leniência pelo prazo de 3 (três) anos, contado da data de seu julgamento.

Art. 87. Nos crimes contra a ordem econômica, tipificados na Lei $n^{\circ}$ 8.137, de 27 de dezembro de 1990, $e$ nos demais crimes diretamente relacionados à prática de cartel, tais como os tipificados na Lei $n^{\circ} 8.666$, de 21 de junho de 1993, e os tipificados no art. 288 do Decreto-Lei $n^{\circ} 2.848$, de 7 de dezembro de $1940-$ Código Penal, a celebração de acordo de leniência, nos termos desta Lei, determina a suspensão do curso do prazo prescricional e impede o oferecimento da denúncia com relação ao agente beneficiário da leniência.

Parágrafo único. Cumprido o acordo de leniência pelo agente, extingue-se automaticamente a punibilidade dos crimes a que se refere o caput deste artigo." (grifos nossos relativos às mudanças implementadas no antigo Programa de Leniência). 
Relembre-se que o alicerce do instituto reside no estímulo aos infratores em comparecer perante o órgão de defesa da concorrência.

Além do mais, manteve-se a alteração contida no Projeto de Lei $n^{\circ}$ 5.877/2005 a respeito da extensão dos efeitos do acordo a empresas do mesmo grupo, de fato ou de direito, e aos seus dirigentes, administradores e empregados envolvidos na infração, sempre no intuito de tornar o instituto cada vez mais atraente aos olhos do infrator e levando em conta a realidade das empresas e dos empresários.

Em que pese o acerto da manutenção dessa alteração, olvidou-se o legislador de incluir a expressão "atuais ou já desligados da empresa", muito utilizada nas legislações que regulamentam o Programa de Leniência em outros países. Caso assim o fizesse, garantiria os benefícios do acordo a todos os dirigentes, administradores e empregados da empresa que efetivamente se envolveram na conduta cartelizadora, ainda que, após os fatos, qualquer um deles tenha se desvinculado, a qualquer título, da pessoa jurídica.

Já o $§ 12$ do artigo 86 da Lei recém-aprovada dispõe acerca de um período de depuração de três anos ao leniente que descumprir o acordo. Ao que parece, pretende-se punir aquele que, na tentativa de obter os benefícios penais e administrativos, ludibrie as autoridades com informações e provas falsas, frágeis ou inconsistentes.

A última novidade trazida pela Lei em comento guarda relação com a abrangência da imunidade penal conferida ao leniente que cumprir devidamente o acordo. Como visto em tópicos anteriores, o atual artigo $35-\mathrm{C}$ da Lei ${ }^{\circ}$ 8.884/94 vem recebendo críticas desde o seu nascedouro, impondo-se a sua revisão e alteração.

Isso porque, a imunidade penal proposta pelo legislador abrange tão somente os crimes contra a ordem econômica previstos na Lei $\mathrm{n}^{\circ} 8.137 / 90$ - na realidade, após a entrada em vigor da Lei $\mathrm{n}^{\mathrm{o}} 12.529 / 11$, apenas os tipos penais contidos no artigo $4^{\circ}$-, sem considerar que os infratores que praticam condutas anticoncorrenciais podem ser acusados pelo cometimento de outros crimes.

Em vista disso, o artigo 87 da Lei $\mathrm{n}^{\circ}$ 12.529/11 determina o impedimento de oferecimento de denúncia nos crimes contra a ordem econômica previstos na Lei $\mathrm{n}^{\circ}$ 8.137/90, assim como “[...] nos demais crimes diretamente relacionados à prática de 
cartel, tais como os tipificados na Lei $n^{\circ}$ 8.666, de 21 de junho de 1993, e os tipificados no art. 288 do Decreto-Lei $n^{\circ}$ 2.848, de 7 de dezembro de 1940 - Código Penal.”

Nessa mesma linha de raciocínio, foi aprovado parecer na Comissão de Ciência, Tecnologia, Inovação, Comunicação e Informática, sob relatoria do senador WELLINGTON SALGADO, que sugeria a seguinte emenda ao projeto de lei:

\section{"EMENDA N”20 - CCT}

Dê-se ao art. 87, caput, do PLC nº 6, de 2009, a seguinte redação: (...) Art. 87 Nos crimes contra a ordem econômica, tipificados na Lei $n^{\circ} 8.137$, de 27 de dezembro de 1990, e nos demais crimes diretamente relacionados à prática de cartel, tais como os tipificados na Lei $n^{\circ} 8.666$, de 21 de junho de 1993 e os tipificados no art. 288 do Código Penal, a celebração de acordo de leniência, nos termos desta Lei, determina a suspensão do curso do prazo prescricional e impede o oferecimento da denúncia com relação ao agente beneficiário da leniência. Parágrafo único. Cumprido o acordo de leniência pelo agente, extingue-se automaticamente a punibilidade dos crimes a que se refere o caput deste artigo.",576

\footnotetext{
${ }^{576}$ A justificativa apresentada para esta emenda restou consignada no próprio parecer: "[...] II.B - Propostas de alterações Com vistas a propiciar melhoras ainda mais significativas em prol da defesa da concorrência em nosso País, apresento as emendas a seguir relacionadas: (...)

x) O impedimento do oferecimento de denúncia pelos crimes tipificados no art. 288 do Código Penal quando celebrado o acordo de leniência, com o acréscimo, no artigo 87 a expressão 'e os tipificados no art. 288, do Código Penal'. O Brasil deve considerar o combate a cartéis como uma prioridade. É uma conduta espúria que limita a concorrência artificialmente, importa em perda de bem estar do consumidor e de competitividade na economia, gera sobrepreço de até $20 \%$ (vinte por cento) conforme informações da Organização para a Cooperação e Desenvolvimento Econômico - OCDE e causa prejuízos de alta monta aos consumidores. Infelizmente tais comportamentos são de difícil detecção. Os envolvidos se utilizam, v.g., de encontros 'secretos', e-mails 'criptografados', celulares pré-pagos, comunicação com termos 'codificados' e outros métodos em contínua 'evolução' para a constituição e manutenção de um cartel. Por essa razão, é difícil a colheita de provas a respeito sem informações de alguém 'de dentro', efetivamente envolvido na própria estrutura colusiva. Por esse motivo, há o programa de leniência, pelo qual são celebrados acordos com pessoas físicas e jurídicas em troca da confissão ou da colaboração nas investigações. Ciente de que a informação trazida por um 'delator' é de extrema validade para que seja desmontado um cartel com outras tantas partes envolvidas, é preciso que o estímulo para essa atitude seja considerável. Nesse ponto, a lei oferece que, em troca, seja extinta total ou parcialmente a penalidade administrativa e também seja extinta a punibilidade em relação aos crimes previstos na Lei $n$. 8.137/90 - Lei dos Crimes Contra a Ordem Econômica. Ocorre que os beneficiários dos acordos de leniência vêm sendo processados por crime de quadrilha ou bando, o que pode afastar pretendentes à leniência, temerosos de que a "imunidade" prometida não se revele efetiva em relação a dito tipo penal. Com o escopo de manter o Programa de Leniência nessa trajetória ascendente de celebrada efetividade no âmbito nacional e internacional, é importante a eliminação desse risco ao beneficiário, o que justifica a proposta de acréscimo." (grifos nossos) (BRASIL. SENADO. Parecer aprovado na comissão de ciência, tecnologia, inovação, comunicação e informática).
} 
Merecem aplausos tanto o dispositivo contido na nova Lei quanto a emenda aprovada pela Comissão de Ciência, Tecnologia, Inovação, Comunicação e Informática. Fazia-se necessária a previsão expressa de uma segurança jurídica maior ao leniente no que tange ao benefício oferecido.

É inaceitável que o proponente receba imunidade apenas pelos crimes previstos na Lei $n^{\circ} 8.137 / 90$, ao passo que as acusações que envolvem a prática de cartel podem trazer a imputação de diversos outros tipos penais, mormente o artigo 90 da Lei $\mathrm{n}^{\circ}$ 8.666/93 e, ainda que equivocadamente, conforme demonstrado no subitem 4.2.2.5, o artigo 288 do Diploma Penal. Daí a expressão "nos demais crimes diretamente relacionados à prática de cartel" ao se referir à imunidade penal.

Como já apontado em tópico anterior, deve-se atentar ao fato de que a inovação legislativa não pode trazer imunidade total para todo e qualquer delito perpetrado pelo leniente no período em que praticou o crime de formação de cartel. Somente os delitos considerados meio para a conduta cartelizadora e estritamente vinculados a ela devem ser abarcados pelo benefício penal.

Cumpre observar que um significativo motivo que conduz a legislação a se fortalecer e a se apresentar firme e segura consiste no impulso que o receio de ser descoberto pelas autoridades antitruste ocasiona e leva os participantes do cartel a firmarem um acordo de leniência. ${ }^{577}$

Note-se que a referida emenda apresenta sugestão extremamente atual, pois segue orientação contida no recém-elaborado Relatório da OCDE Lei e Política de Concorrência no Brasil - Uma revisão pelos pares de 2010, registrada nos seguintes termos:

“[...] 7.2.1.9. Modificar o Programa de Leniência para eliminar a exposição dos beneficiários da leniência a outros processos penais, para além da Lei de Crimes contra a Ordem Econômica. O Programa de Leniência do SBDC está provando ser bem sucedido, e tem gerado diversas candidaturas. O Programa estipula que os indivíduos que receberem leniência também receberão imunidade na ação criminal sob a Lei de Crimes contra a Ordem Econômica. Entretanto, eles não recebem atualmente imunidade no âmbito de outras leis criminais que possam ser aplicadas a casos de conduta. Isto pode inibir alguns interessados de se candidatarem no Programa de Leniência." (OCDE. Lei e política de concorrência no Brasil: uma revisão pelos pares - 2010). (grifos nossos)

577 Nesse sentido, JULIANA GIRARDELLI VILELA declara que: “É importante ressaltar que, se as empresas percebem que o risco advindo da descoberta pelo cartel pelas autoridades antitruste é muito pequeno, então, as penalidades mais pesadas não serão suficientes para conter o cartel. Se os membros do cartel não sentem receio em serem descobertos, não se sentirão inclinados a relatar, às autoridades competentes, seus delitos em troca da leniência. Portanto, é necessário que tais autoridades processem uma legislação forte e eficaz, capaz de criar um ambiente de receio, a fim de que executivos possam perceber que há riscos significativos caso venham a integrar ou continuem participando de algum cartel.

Dessa forma, o fato de o governo vir a descobrir a participação das empresas em algum cartel pode ser motivo de grande ansiedade para seus membros e gerar uma verdadeira corrida ao Judiciário. Ocorre que, 
Por outro lado, é indispensável que a legislação traga garantias ao leniente, definindo de maneira clara e objetiva quais os requisitos do acordo, seu procedimento e benefícios, de modo a estabelecer uma relação entre autoridade e candidato acobertada pela mais lídima segurança jurídica.

Infelizmente, sob esse aspecto, a nova Lei não andou bem, porquanto manteve, em sua maioria, os mesmos requisitos e termos do procedimento do acordo de leniência previstos na legislação anterior, conservando as inseguranças já destacadas no subitem 4.2.2.1. Dentre elas, a mais preocupante consiste na manutenção da exigência da confissão para a celebração do acordo, condição sine qua non para que o candidato à leniência seja habilitado no programa e, posteriormente, por vezes, receba os benefícios desejados.

Isto porque é indiscutível que a confissão do participante pode, a qualquer momento, transformar-se em um consistente elemento autoincriminatório. Diante da manutenção dos vigentes dispositivos legais a respeito, considerando a permanente incerteza existente quanto à efetiva celebração do acordo pela Superintendência-Geral do CADE, a confissão pode apresentar-se como prova inequívoca para a propositura de uma bem-sucedida ação penal.

Fatalmente, o acordo de leniência torna-se menos atraente aos olhos dos infratores, que, embora interessados em colaborar e cessar a prática anticoncorrencial, acabam por preferir a permanência na atividade ilícita, arriscando a sorte e desafiando as autoridades antitruste, em razão do temor dos reflexos penais de uma confissão.

Some-se a isso o fato de que a confissão do candidato a leniente poderá instruir futuras ações cíveis de indenização contra si, o que, inevitavelmente, contribui para a diminuição no interesse em buscar a celebração do acordo.

Definitivamente, não é esse o intuito da Política Nacional de Proteção da Ordem Econômica, já que o acordo de leniência é o seu pilar fundamental, o "carro-chefe" do combate a cartéis no Brasil. Ademais, para as autoridades antitruste, não é apenas a confissão que interessa. Ao contrário, o que se pretende com este acordo são informações sólidas e provas robustas sobre um ilícito anticompetitivo, bem como a cessação definitiva

havendo sérios prejuízos para a empresa se o cartel for descoberto, nem a companhia nem o indivíduo ficarão inertes ante a possibilidade de que outros procurem a Divisão Antitruste mais rapidamente $e$ usufruam, primeiro, dos benefícios da leniência.” (Op. cit., p. 205). 
desta prática, sem que seja necessário o aporte de grandes recursos financeiros e afastada a existência de um burocrático e moroso procedimento administrativo.

Por esse motivo, julga-se que a novel legislação poderia trazer alterações também nesse particular aspecto do instituto, substituindo o termo "confissão" por "colaboração", tal qual sugerido anteriormente, no subitem 4.2.3, para os dispositivos do Termo de Compromisso de Cessação de Prática. Isto porque a colaboração do leniente é capaz de oferecer às autoridades competentes informações e provas necessárias para o desmantelamento do cartel, com celeridade, simplicidade e economia desejadas, sem desestimular o candidato, mantendo-se, assim, a eficácia do instituto.

Note-se que, a bem da verdade, é de todo desnecessária a confissão do leniente, posto que, ao final, de um modo ou de outro, seja com a confissão, seja com a colaboração, ele não será punido criminalmente, pois a extinção da punibilidade é a grande premiação oferecida em troca da preciosa delação. Diante disso, por que não oferecer maior segurança jurídica ao leniente tornando o instituto mais atraente e sedutor aos infratores?

E nem se argumente que a ausência da exigência da confissão dará contornos menos severos ao instituto, de modo que essa alteração provocará uma percepção pública negativa - aos cidadãos em geral e aos empresários em particular - sobre a gravidade da conduta cartelizadora, ou, ainda, que esta modificação poderá reduzir os efeitos dissuasórios da investigação.

Os tipos penais que preveem as condutas anticoncorrenciais e as suas severas punições permanecerão os mesmos, assim como os eficazes meios investigatórios utilizados no combate ao cartel. Igualmente, os benefícios concedidos ao leniente, em especial, a extinção da punibilidade penal, continuarão os mesmos. Assim, o binômio custo $\mathrm{x}$ benefício para a leniência analisado pelo infrator e até pelo cidadão não alterará. A premiação somente será concedida se oferecidos elementos probatórios acerca da materialidade e autoria da prática anticompetitiva, o que, de fato, interessa para as autoridades antitruste.

Destarte, conveniente e oportuna a alteração sugerida, embora sequer aventada na Lei ora em estudo. 
Diante dessas ponderações, depreende-se que as propostas que tramitaram nas Casas Legislativas pátrias e a consequente Lei recém-promulgada, em que pese o fato de estarem distantes de um projeto ideal sobre o tema, caminham para essa evolução. São louváveis, portanto, as iniciativas.

A fim de contribuir para que não sejam mantidos os mesmos equívocos da antiga legislação sobre o tema e aproveitando a oportunidade de modificação de toda a Lei Antitruste, em atendimento às críticas e comentários tecidos ao longo deste trabalho, propõe-se a adoção de uma nova redação do capítulo que dispõe acerca do Programa de Leniência:

“[...]

CAPÍTULO VII

DO PROGRAMA DE LENIÊNCIA

\section{(...)}

Art. 86. O CADE, por intermédio da Superintendência- Geral, com a intervenção do Ministério Público Federal e Estadual - com atribuições cíveis e criminais -, poderá celebrar acordo de leniência, com a extinção da ação punitiva da administração pública ou a redução de 1 (um) a 2/3 (dois terços) da penalidade aplicável, nos termos deste artigo, com pessoas físicas e jurídicas que forem possíveis autoras de infração à ordem econômica, desde que colaborem efetivamente com as investigações e o processo administrativo e que dessa colaboração resulte:

I - a identificação dos demais envolvidos na infração; e

II - a obtenção de informações e documentos que auxiliem na comprovação da infração noticiada ou sob investigação.

$\S 1^{\circ} \mathrm{O}$ acordo de que trata o caput deste artigo somente poderá ser celebrado se preenchidos, cumulativamente, os seguintes requisitos:

I - a pessoa física ou jurídica seja a primeira a se qualificar com respeito à infração noticiada ou sob investigação;

II - a pessoa física ou jurídica cesse completamente seu envolvimento na infração noticiada ou sob investigação a partir da data de propositura do acordo; 
III - a Superintendência-Geral não disponha de provas suficientes para comprovar a prática da infração por ocasião da propositura do acordo; e

IV - a pessoa física ou jurídica colabore plena e permanentemente com as investigações e o processo administrativo, comparecendo, sempre que solicitada, a todos os atos processuais, até seu encerramento.

$\S 2^{\circ}$ Com relação às pessoas físicas ou jurídicas que não se apresentarem como primeiras na qualificação perante a Superintendência-Geral no que se refere à infração noticiada ou sob investigação, elas poderão celebrar acordo de leniência desde que cumpridos os requisitos II, III e IV do $§ 1^{\circ}$ deste artigo.

$\S 3^{\circ} \mathrm{O}$ acordo de leniência firmado com o CADE, por intermédio da Superintendência-Geral, estipulará as condições necessárias para assegurar a efetividade da colaboração e o resultado útil do processo.

$\S 4^{\circ}$ Compete ao Tribunal, após o cumprimento dos requisitos do acordo, por ocasião do julgamento do processo administrativo:

I - decretar a extinção da ação punitiva da administração pública em favor do suposto infrator que primeiro se apresentar às autoridades, nas hipóteses em que a proposta de acordo tiver sido apresentada à Superintendência-Geral sem que essa tivesse conhecimento prévio da infração noticiada; ou

II - nas demais hipóteses, reduzir de 1 (um) a 2/3 (dois terços) as penas aplicáveis, observado o disposto no art. 45 desta Lei, devendo ainda considerar na gradação da pena a efetividade da colaboração prestada e a boafé do infrator no cumprimento do acordo de leniência.

$\S 5^{\circ} \mathrm{Na}$ hipótese do inciso II do $\S 4^{\circ}$ deste artigo, o Tribunal deverá observar as seguintes diretrizes:

I - a pena sobre a qual incidirá o fator redutor não será superior à menor das penas aplicadas aos demais co-autores da infração, relativamente aos percentuais fixados para a aplicação das multas de que trata o inciso I do art. 37 desta Lei;

II - o fator redutor deverá seguir uma ordem decrescente de gradação, tendo em vista o momento de qualificação do suposto infrator perante a Superintendência-Geral do CADE, de modo que o último proponente não poderá receber redução maior que aquela destinada aos anteriores.

$\S 6^{\circ}$ Serão estendidos às empresas do mesmo grupo, de fato ou de direito, e aos seus dirigentes, administradores e empregados envolvidos (atuais ou já desligados da empresa) na infração os efeitos do acordo de leniência, desde que o firmem em conjunto, respeitadas as condições impostas. 
$\S 7^{\circ}$ A empresa ou pessoa física que não obtiver, no curso de inquérito ou processo administrativo, habilitação para a celebração do acordo de que trata este artigo, poderá celebrar com a Superintendência-Geral, até a remessa do processo para julgamento, acordo de leniência relacionado a uma outra infração, da qual o CADE não tenha qualquer conhecimento prévio.

$\S 8^{\circ} \mathrm{Na}$ hipótese do $\S 6^{\circ}$ deste artigo, o infrator se beneficiará da redução de 1/3 (um terço) da pena que lhe for aplicável naquele processo, sem prejuízo da obtenção dos benefícios de que trata o inciso I do $\S 4^{\circ}$ deste artigo em relação à nova infração denunciada.

$\S 9^{\circ}$ Considera-se sigilosa a proposta de acordo de que trata este artigo, salvo no interesse das investigações e do processo administrativo.

$\S$ 10. Não importará em confissão quanto à matéria de fato, nem reconhecimento de ilicitude da conduta analisada, a proposta de acordo de leniência rejeitada, da qual é terminantemente proibida a divulgação, incluídos os documentos apresentados pelo proponente.

$\S$ 11. A aplicação do disposto neste artigo observará as normas a serem editadas pelo Tribunal.

$\S$ 12. Em caso de má-fé no descumprimento do acordo de leniência, o beneficiário ficará impedido de celebrar novo acordo de leniência pelo prazo de 3 (três) anos, contado da data de seu julgamento.

Art. 87. Nos crimes de formação de cartel - especialmente os tipificados na Lei $n^{\circ} 8.137$, de 27 de dezembro de 1990 e na Lei $n^{\circ} 8.666$, de 21 de junho de 1993 - e nos demais crimes considerados meio para a sua prática, a celebração de acordo de leniência, nos termos desta Lei, determina a suspensão do curso do prazo prescricional e impede o oferecimento da denúncia com relação ao agente beneficiário da leniência que primeiro se qualificou no programa.

$\S 1^{\circ}$ Após finalizado o acordo de leniência, este será remetido ao juiz competente que verificará o cumprimento de seus termos e determinará a extinção da punibilidade com relação aos crimes a que se refere o caput deste artigo.

$\S 2^{\circ}$ Na hipótese prevista no $\S 2^{\circ}$ do artigo 86, ao condenar o acusado leniente na esfera criminal, o juiz competente diminuirá a sua pena de 1 (um) a 2/3 (dois terços), respeitados os critérios previstos nos $\$ \$ 4^{\circ}$, inciso II e $5^{\circ}$, inciso II do artigo 86." (grifos nossos referentes às mudanças propostas em comparação com o Projeto de Lei nº 06/2009) 
Com essas alterações legislativas, espera-se suprir todas as deficiências do Programa de Leniência apontados no decorrer do presente trabalho, adequando-o aos princípios constitucionais e a todo o ordenamento jurídico pátrio, trazendo, como consequência, maior segurança e garantia ao leniente, de modo a estimular cada vez mais a utilização deste instituto tão eficaz no combate aos crimes de formação de cartel. 


\section{CONCLUSÃO}

O estudo acerca dos crimes contra a ordem econômica, em especial dos delitos concorrenciais, exige um abrangente conhecimento sobre todo o sistema econômico, a disciplina jurídica do poder econômico e a legislação antitruste.

Durante longo período, os preceitos do liberalismo ditaram as regras no sistema econômico, ou melhor, afastaram do Estado qualquer tipo de atuação no mercado, deixando os indivíduos agirem livremente. O Estado passou a exercer um papel restrito diante dos fatos econômicos e sociais, encontrando barreiras para qualquer posição mais ofensiva. Sustentava-se que as leis de oferta e procura eram suficientes para que a economia se autorregulasse.

Com o passar dos tempos, notou-se que essa conduta liberal provocava diversos efeitos colaterais decorrentes de falhas do mercado que causavam enormes prejuízos a toda a coletividade, de modo que se percebeu necessária a atuação de um agente externo para saná-las. Assim é que, paulatinamente, o Estado voltou a intervir na economia.

Nesse quadro, diante do colapso sofrido pela crença no automatismo dos processos do liberalismo, surgiu o Direito Econômico, que passou a garantir a organização e o funcionamento da economia - o que pressupõe a correção das falhas de mercado -, com técnicas que instituíam a primazia do interesse econômico geral, sem suprimir a atividade lucrativa dos particulares. Para atingir este objetivo, apareceram as Constituições Econômicas, que, operando a conversão do regime econômico em ordem jurídicoeconômica, estabeleceram as regras e os princípios informadores das normas que regeriam as relações econômicas.

Com o Direito Econômico, surgiu a disciplina da concorrência, um dos vários instrumentos de que faz uso o Estado para tentar afastar os efeitos lesivos do livre mercado, mediante a utilização de normas que se destinam a tutelar a livre concorrência entre os agentes ou reprimir o abuso do poder econômico. Tais normas são orientadas por três interesses, a saber: o institucional da ordem concorrencial, o dos consumidores e o dos participantes do mercado. 
Nesse contexto, no final da segunda década do século passado, constatou-se uma tendência de criminalização, consistente na emissão desordenada de regras penais contra condutas repelidas pelo Direito Econômico, que fez surgir um novo ramo do Direito Penal: o Direito Penal Econômico. Não foi diferente com as condutas anticoncorrenciais, que, a par de já constituírem infrações administrativas, foram transformadas em tipos penais repletos de expressões técnicas e de difícil compreensão, dentre eles, a formação de cartel.

A esse ponto, vale ponderar que a simples constatação de a livre concorrência estar prevista como elemento essencial da ordem econômica em nível constitucional e, por outro lado, se enquadrar como bem jurídico penal supraindividual não basta para justificar a obrigatoriedade do uso da via penal para a sua tutela, em que pese o fato de os legisladores brasileiros terem elegido as normas penais para prevenir e reprimir as condutas anticoncorrenciais. Como se sabe, a tutela da concorrência depende de instrumentos sancionatórios eficientes, nem sempre encontrados na esfera penal, ainda que haja fundamento formal para se adotar esta via.

Seja na esfera administrativa, seja na penal, dentre as condutas que podem ser praticadas pelos indivíduos em prejuízo da concorrência, incluem-se, dentre as mais nocivas ao mercado, os acordos entre os agentes econômicos que tenham por objeto ou possam produzir os seguintes efeitos:

- Limitar, falsear ou de qualquer forma prejudicar a livre concorrência ou a livre iniciativa.

- Dominar mercado relevante de bens ou serviços.

- Aumentar arbitrariamente os lucros.

- $\quad$ Exercer de forma abusiva posição dominante.

Tais acordos são classificados em duas espécies pela doutrina: acordos horizontais, os conhecidos cartéis, e os acordos verticais. Os primeiros caracterizam-se pelo fato de envolver agentes econômicos que atuam em um mesmo mercado relevante (geográfico e material), encontrando-se em direta relação de concorrência e os últimos disciplinam relações entre agentes econômicos que atuam em mercados relevantes diferentes. 
Especificamente na área penal, os ilícitos anticoncorrenciais são previstos na Lei $n^{\circ}$ 8.137/90 em seus artigos $4^{\circ}$ e $5^{\circ}$. Dentre esses tipos penais, encontra-se o delito de formação de cartel, especificamente no artigo $4^{\circ}$ e seus incisos I, alíneas "a" e "b", III e V. Sua detecção e apuração são de extrema dificuldade, pois o acordo entre os agentes econômicos não costuma ser formalizado e, por vezes, são utilizados recursos altamente tecnológicos que permitem às partes a combinação do ilícito à distância sem deixar rastros, atrapalhando ainda mais a identificação do ajuste. Além disso, distingue-se o cartel por ser uma das mais perniciosas infrações anticoncorrenciais, eis que detém o potencial de provocar incontáveis prejuízos, como: exclusão de concorrentes do mercado, alta elevação de preços aos consumidores e oferta de produtos de baixa qualidade.

É precisamente este crime que o Programa de Leniência pretende combater. Com uma frequência maior da formação de cartéis, bem como diante da imensa dificuldade em se investigar este tipo de ilícito e da completa falência de várias práticas adotadas para a sua apuração, introduziu-se no ordenamento jurídico o acordo de leniência, instrumento de investigação semelhante à delação premiada.

Preenchidos determinados requisitos, o acordo de leniência implica, no âmbito administrativo, em reduções nas sanções ou até na extinção da ação punitiva da administração e, no âmbito penal, na extinção da punibilidade dos crimes contra a ordem econômica em tese praticados.

É bem verdade que este instituto é amplamente utilizado em diversos países - sobretudo nos Estados Unidos da América, pioneiros no tema -, de modo que o cotejo analítico realizado a partir de sua regulamentação em outras nações auxilia na busca de falhas e incongruências de sua previsão na legislação nacional e na sua evolução. Entretanto, é evidente que não basta a simples importação do acordo de leniência tal qual aplicado em outros países, tornando-se necessária a sua adequação ao ordenamento jurídico brasileiro.

Examinado sob o ponto de vista da ética, o Programa de Leniência mostra-se um tanto inadequado, eis que baseado exclusivamente na traição estimulada a qualquer preço. A depender das intenções do delator - obter a imunidade, vingar-se do concorrente, prejudicar um agente econômico mais forte etc. -, o próprio teor das informações fornecidas às autoridades antitruste é contestável, revelando uma grande fragilidade do 
instituto. Não por esse motivo, o acordo de leniência deve ser ignorado como realidade fática dos tempos modernos. É substancial que ele seja reconhecido pela sua eficácia e utilizado como um dos instrumentos de combate a cartéis pelas autoridades antitruste de todo o mundo.

Da maneira como regulamentado, o acordo de leniência tem gerado impactos na esfera penal em absoluta dissonância com a Carta Magna e a legislação ordinária, trazendo inegável insegurança jurídica ao delator. Primeiramente, em razão dos critérios subjetivos e obscuros que permeiam a sua celebração e, notadamente, os seus resultados. As expressões utilizadas na Lei $n^{\circ}$ 8.884/94 e na Portaria do Ministério da Justiça $n^{\circ}$ 456/2010 são de difícil compreensão e permitem uma interpretação dúbia acerca dos requisitos e efeitos do acordo.

Desse modo, a ausência de previsão acerca da participação do Ministério Público órgão responsável por promover a ação penal em face do delator e dos demais envolvidos na prática delituosa - na celebração do acordo traz dúvidas quanto ao cumprimento do principal efeito do instituto na seara penal, qual seja, a extinção da punibilidade do leniente.

Também é contestada a forma pela qual se dá o reconhecimento da extinção da punibilidade do delator, porquanto a legislação vigente prevê a sua declaração automática pelas próprias autoridades administrativas, à revelia de qualquer apreciação pelo Poder Judiciário.

Uma outra questão controvertida acerca dos reflexos do instituto consiste no sigilo, ou na sua ausência, das provas produzidas por seu intermédio e da possibilidade de estas serem utilizadas posteriormente, quando da não celebração efetiva do acordo, tendo em vista que ao se candidatar à leniência, o suposto infrator é compelido a revelar às autoridades elementos probatórios concretos sobre a conduta delitiva.

A sua fragilidade também é exposta em virtude da ausência de previsão da extinção da punibilidade com relação a outros delitos diretamente relacionados com a prática da formação de cartel e de outras condutas cartelizadoras não previstas na Lei no 8.137/90. Se, de um relato da formação de um crime de cartel, restar evidenciado o cometimento de delitos - como o de falsidade ideológica, ameaça ou quadrilha, ainda que diretamente 
relacionado ao cartel como crime-meio para a prática da conduta cartelizadora -, estes não serão objeto da imunidade penal.

Outro ponto nevrálgico do instituto aponta para o paralelismo de apurações concomitantes nas esferas penal e administrativa de infrações semelhantes e consiste na necessidade premente de aplicação da suspensão do processo penal até o deslinde final do procedimento administrativo, especialmente nos casos de condutas lesivas à ordem econômica, com a finalidade de evitar que as mesmas práticas tenham resultados diversos nas duas instâncias.

Por fim, a somar às circunstâncias anteriores, a regulamentação vigente acerca do acordo de leniência e do termo de compromisso de cessação de prática apresenta inúmeras incongruências que enfraquecem tanto um quanto outro instituto.

Diante destas constatações e reflexões acerca da regulamentação do Programa de Leniência e considerando as recentes alterações trazidas pela Lei $n^{\circ} 12.529 / 11$, o presente trabalho apresenta nova proposta de modificação dos dispositivos legais, com o firme propósito de sanar todas as imperfeições, falhas e contradições existentes na atual regulamentação do instituto aqui apontadas, bem como de promover a manutenção do programa em total concordância com a Constituição Federal, garantindo a sua eficácia. 


\section{REFERÊNCIAS}

ABRÃO, Guilherme Rodrigues. O acordo de leniência no direito penal. Disponível em <http://www.ibccrim.org.br/site/artigos/_imprime.php?jur_id=9724>. Acesso em 12 de maio de 2008.

AFTALIÓn. Enrique R. Derecho Penal Económico. Buenos Aires: Abeledo-Perrot, 1959.

AGUILLAR, Fernando Herren. Direito econômico: do direito nacional ao direito supranacional. São Paulo: Atlas, 2006.

AKERLOF, George A The market for "lemons": quality uncertainty and the market mechanism. The Quartely Journal of economics. MIT Press. Disponível em <http://links.jstor.org/sici?=0033_5533\%28197008\%2984\%3A3\%C488\%3ATMF\%22QU \%3E2.0.CO\%3B2-6>. Acesso em 22 de outubro de 2009.

ANDRADE, Manuel da Costa. A 'dignidade penal' e a 'carência de tutela penal'como referências de uma doutrina teleológica-racional do crime. Revista Portuguesa de Ciência Criminal. Lisboa: Aequitas Editorial Notícias, no 2, pp. 173/205, Ano 2, abr./jun., 1992.

ANDRADE FILHO, Arthur Guerra de. $\mathbf{O}$ acordo de leniência como instrumento para o combate a cartéis. Monografia de Graduação. São Paulo: Faculdade de Direito, Pontifícia Universidade Católica, 2006.

AUSTRÁLIA. AUSTRALIAN COMPETITION \& CONSUMER COMMISSION. ACCC immunity policy for cartel conduct. Disponível em <http://www.accc.gov.au/ content/item.phtml itemId=879795\&nodeId=f66a352b170982e5308039195ba68521\&fn=I mmunity\%20policy\%20for\%20cartel\%20conduct.pdf >. Acesso em 11 de junho de 2011.

ACCC immunity policy interpretation guidelines. Disponível em <http://www.accc.gov.au/content/item.phtml?itemId=879795\&nodeId=eb2cc256f6140a0f 
6a026e3b9aae9db9\&fn=Immunity\%20policy\%20interpretation\%20guidelines.pdf $>$. Acesso em 11 de junho de 2011.

Cartel conduct. Disponível em <http://www.accc.gov.au/content/ index.phtml /itemId/883986?pageDefinitionItemId=86167\#h3_66>. Acesso em 12 de junho de 2011.

Memorandum of understanding between commonwealth director of public prosecution and australian competition and consumer commision. Disponível em <http://www.acc.gov.au/content/item.phtml?itemId=882220\&nodeId=ef73337d44a8c8ee 9ffd593f93cb0699\&fn=Memorandum\%20of\%20understanding\%20\%20between\%20CDP P\%20and\%20ACCC.pdf>. Acesso em 12 de junho de 2011.

BIANCHINI, Alice. Direito penal econômico: os fins justificam os meios? Boletim IBCCrim, São Paulo: IBCCrim, vol. 7, nº 84, pp. 09/10, nov., 1999.

BOTTINI, Pierpaolo Cruz. Crimes de perigo abstrato. 2. ed., rev. e atual., São Paulo: Revista dos Tribunais, 2010.

BRANCO, Nelson de Andrade; BARRETO, Celso de Albuquerque. Repressão ao abuso do poder econômico. São Paulo: Atlas, 1964.

BRASIL. IBRAC. Relatório de sugestões de aperfeiçoamento do programa de leniência brasileiro. Disponível em <http://www.ibrac.org.br/Evento.aspx? $\mathrm{Id}=16>$. Acesso em 25 de agosto de 2009.

BRASIL. MINISTÉRIO DA JUSTIÇA. CADE. Cartilha do CADE. Disponível em <http://www.cade.gov.br/publicacoes/cartilhaport.asp>. Acesso em 22 de janeiro de 2007.

Estrutura do sistema brasileiro de defesa da concorrência. Disponível em <http://www.cade.gov.br/Default.aspx?71b172be4dcb4cee470b>. Acesso em 20 de agosto de 2011. 
. Guia Prático do CADE: a defesa da concorrência no Brasil. Disponível em <http://www.cade.gov.br/publicacoes/guia_cade_3d_10108.pdf >. Acesso em 6 de outubro de 2010.

. Política da SDE - Termo de Compromisso de Cessação de Prática em cartel. Disponível em <http://portal.mj.gov.br/sde/data/Pages/MJ9F537202ITEMID597B15F35 E7043448D2E1D00D14E5804PTBRIE.htm>. Acesso em 5 de maio de 2008.

. Processo Administrativo no 08012.002127/2002-14.

. Processo Administrativo no 08700.001882/2008-19.

. Processo Administrativo no 26, de 1971.

. Procedimento Administrativo $n^{\mathbf{0}}$ 080.12.005669/2002-31. Disponível em <http://www.cade.gov.br/Default.aspx?d051a275bd53a77c948590aaba>. Acesso em 2 de agosto de 2011.

Relatório sugere mudanças para a área de concorrência. Brasília, 6 de outubro de 2005. Disponível em <http://www.cade.gov.br/noticias/release\%20sbdc.pdf>. Acesso em 4 de agosto de 2008.

. Resolução no 20, de 09 de junho de 1999.

. Resolução no 46, de 06 de setembro de 2007.

Portaria no 456, de 15 de março de 2010.

Portaria $n^{\circ}$ 04, de 05 de janeiro de 2006.

BRASIL. MINISTÉRIO DA JUSTIÇA. SECRETARIA DE DIREITO ECONÔMICO. Cartilha sobre combate a cartéis em licitações. Disponível em <www.mj.gov.br>. Acesso em 3 de maio de 2009. 
Cartilha sobre o combate a cartéis em sindicatos e associações. Disponível em <www.mj.gov.br>. Acesso em 5 de maio de 2009.

Cartilha sobre combate a cartéis e programa de leniência. Disponível em <www.mj.gov.br>. Acesso em 3 de julho de 2008.

BRASIL. MINISTÉRIO PÚBLICO DO ESTADO DE SÃO PAULO. Procuradoria de justiça de interesses difusos e coletivos. Disponível em <http://www.mp.sp.gov.br/portal/page/portal/procuradoria_interesses_difusos_coletivos>. Acesso em 18 de julho de 2011.

BRASIL. TRIBUNAL REGIONAL FEDERAL DA $4^{\mathrm{a}}$ REGIÃO. Processo $\mathbf{n}^{\mathbf{0}}$ 2003.71.00.007397-5. Disponível em <http://www.trf4.jus.br/trf4/processos /visualizar _documento_gedpro.php?local=jfrs $\&$ documento $=768513 \&$ DocComposto $=\&$ Sequencia $=\&$ hash=575f8aa440caa11bf4c3bcda35eda8bc >. Acesso em 3 de agosto de 2011 .

BRASIL. SENADO. Parecer aprovado na comissão de ciência, tecnologia, inovação, comunicação e informática. Disponível em <http://www.senado.gov.br/senadores /senador/wellingtonsalgado/detalha_proposicoes.asp?codigo=598>. Acesso em 31 de agosto de 2010.

BRASIL. SUPREMO TRIBUNAL FEDERAL. AC 1.657/MC. Rel. Min. Joaquim Barbosa, Tribunal Pleno, voto do min. Cezar Peluso, DJ 31.08.2007

CABRERA, Raul Peña. El bien jurídico en los delitos económicos. Revista Brasileira de Ciências Criminais. São Paulo: IBCCrim, vol. 3, nº 11, pp. 36/49, jul./set., 1995.

CALAMANDREI, Piero. Istituzioni di diritto processuale civile, secondo il nuovo codice. 2. ed. Pádua: Cedam, 1943.

CAMARGO, Marcelo Ferreira de. $\mathbf{O}$ acordo de leniência no sistema jurídico brasileiro. Disponível em <http://jus2.uol.com.br/doutrina/texto.asp?id=5426>. Acesso em 6 de maio de 2008. 
CANADÁ. COMPETITION BUREAU. Corporate immunity agreement. Disponível em <http://www.competitionbureau.gc.ca/eic/site/cb-bc.nsf/eng/02479.htm>. Acesso em 10 de junho de 2011.

Immunity program: frequently asked questions. Disponível em <http://www.competitionbureau.gc.ca/eic/site/cb-bc.nsf/eng/03250.html>. Acesso em 10 de junho de 2011.

Individual immunity agreement. Disponível em <http://www.competition bureau.gc.ca/eic/site/cb-bc.nsf/eng/02481.html>. Acesso em 10 de junho de 2011.

Leniency program bulletin. Disponível em <http://www.competitionbureau. gc.ca/eic/site/cb-bc.nsf/eng/03288.html>. Acesso em 10 de junho de 2011.

Leniency Program. FAQs. Disponível em <http://www.competitionbureau.gc.ca /eic/site/cb-bc.nsf/eng/03289.html>. Acesso em 10 de junho de 2011.

CANADA. PUBLIC PROSECUTION SERVICE OF CANADA. Federal prosecution service deskbook. Disponível em <http://www.ppsc-sppc.gc.ca/eng/fps-sfp/fpd/ch35. html>. Acesso em 10 de junho de 2011.

CARVAlHOSA, Modesto. A ordem econômica na constituição de 1969. São Paulo: Revista dos Tribunais, 1972.

CARVALHO, Taís. O direito da concorrência e as suas relações com o direito penal. Disponível em <http://jusvi.com/artigos/16050〉. Acesso em 2 de outubro de 2010.

CASTELO BRANCO, Fernando. Reflexões sobre o acordo de leniência: moralidade e eficácia na apuração dos crimes de cartel. In: VILARDI, Celso Sanchez; PEREIRA, Flávia Rahal Bresser; DIAS NETO, Theodomiro (coords.). Direito penal econômico: crimes econômicos e processo penal. São Paulo: Saraiva, pp. 137/165, 2008.

CASTELO BRANCO, Tales. Delação e cumplicidade criminosa. Folha de S. Paulo. Caderno 4, p. 2, 4 de dezembro de 1994. 
COELHO, Fábio Ulhoa. Direito antitruste brasileiro: comentários à Lei no 8.884/94. São Paulo: Saraiva, 1995.

. Caracterização da infração contra a ordem econômica. Revista de Direito Civil, Imobiliário, Agrário e Empresarial. São Paulo: Revista dos Tribunais, no 75, pp. 85/94, jan./mar., 1996.

COHEN, Delphine; ASSADIF-TARDIF, Natasha. Chapter 15: France. In: The international comparative legal guide to: cartels and leniency 2011: a practical crossborder insight into cartels and leniency. Londres: Global Legal Group. Disponível em <http://www.iclg.co.uk/khadmin/Publications/pdf/4105.pdf>. Acesso em 6 de junho de 2011.

COMPARATO, Fábio Konder. O indispensável direito econômico. In: Ensaios e pareceres de direito empresarial. Rio de Janeiro: Forense, 1978.

CÓRDOVA, Danilo Ferraz; LOPES, Mariana Rebuzzi Sarcinelli. Política de combate aos cartéis: os acordos de leniência, o Termo de Compromisso de Cessação e a Lei ${ }^{\circ}$ 11.482/2007. Revista de Direito da Concorrência. Vol. 5, nº 18, pp. 63/90, abr./jun., 2008.

DEI MALATESTA, Nicola Framarino. A lógica das provas em matéria criminal. 3. ed., Campinas: Bookseller, 1996.

DIAS, Jorge de Figueiredo; ANDRADE, Manuel da Costa. Problemática geral das infracções contra a economia nacional. In: PODVAL, Roberto (org.). Temas de Direito Penal econômico. São Paulo: Revista dos Tribunais, 2000, pp. 64/98.

DOTTI, René Ariel. A criminalidade econômica. Revista dos Tribunais. São Paulo: Revista dos Tribunais, ano 74, v. 602, pp. 295/304, 1985.

DRAKAKAK, Stamatis. Chapter 17: Greece. In: The international comparative legal guide to: cartels and leniency 2011: a practical cross-broder insight into cartels and leniency. Londres: Global Legal Group. Disponível em <http://www.iclg.co.uk/ khadmin/Publications/pdf/4107.pdf>. Acesso em 5 de junho de 2011. 
DUTRA, Pedro. Livre concorrência e regulação de mercados. Rio de Janeiro: Renovar, 2003.

ESER, Albin. Sobre la exaltación del bien jurídico a costa de la víctima. Trad. Manuel Cancio Meliá. Bogotá: Universidad Externado de Colombia, 1998.

ESTADOS UNIDOS DA AMÉRICA. DEPARTMENT OF JUSTICE. Corporate leniency policy. Disponível em <http://www.justice.gov/atr/public/guidelines/0091.htm>. Acesso em 2 de junho de 2011.

_. Leniency policy for individuals. Disponível em <http://www.justice.gov/atr/public/guidelines/0092.htm>. Acesso em 2 de junho de 2011.

Model corporate conditional leniency letter. Disponível em <http://www.justice.gov/atr/public/criminal/239524.htm>. Acesso em 2 de junho de 2011.

- Model individual conditional leniency letter. Disponível em <http://www.justice.gov/atr/public/criminal/239526.htm>. Acesso em 2 de junho de 2011.

EUROPA. EUROPEAN COMMISION. Comission notice on the non-imposition or reduction of fines. OJ 1996 C 207/04, de 18.07.96. Disponível em <http://eurlex.europa.eu/LexUriServ/LexUriServ.do?uri=CELEX:31996Y0718(01):IT:HTML>. Acesso em 22 de agosto de 2009.

Commission notice on the non-imposition or reduction of fines. OJ $2-2$ C 45/3, de 19.02.02. Disponível em <http://eur-lex.europa.eu/LexUriServ/LexUriServ.do?uri= OJ:C:2002:045:0003:0005:IT:PDF>. Acesso em 22 de agosto de 2009.

Commision notice on immunity from fines and reduction of fines in cartel cases. OJ 2006/C 298/11, de 08.12.2006. Disponível em <http://eur-lex. europa.eu /LexUriServ/LexUriServ.do?uri=OJ:C:2006:298:0017:0022:PT:PDF>. Acesso em 20 de julho de 2010.

EUROPA. EUROPEAN COMMISSION COMPETITION. Authorities in EU member states which operate a leniency programme. Disponível em 
<http://ec.europa.eu/competition/antitrust/legislation/authorities_with_leniency_programm e.pdf>. Acesso em 2 de junho de 2011.

Cartel statistics. Disponível em <http://ec.europa.eu/competition /cartels/statistics/statistics.pdf>. Acesso em 28 de julho de 2010.

- Leniency. Disponível em <http://ec.europa.eu/competition/cartels/leniency /leniency.html>. Acesso em $1^{\circ}$ de março de 2011.

FÉLIX, Natalia. Direito concorrencial. Considerações sobre a repressão aos cartéis no Brasil. Revista Consultor Jurídico. Disponível em <http://www.conjur.com.br/static/text/68309,1>. Acesso em 24 de julho de 2008.

FERNANDES, Paulo Sérgio Leite. Características da delação premiada. Ponto final. Disponível em <http://www.processocriminalpslf.com.br>. Acesso em 7 de julho de 2008.

FERNANDEZ, Miguel Bajo. El derecho penal económico: un estudio de derecho positivo español. Anuario de derecho penal y ciencias penales, Madrid: BOE, $\mathrm{n}^{\circ} 3$, pp. 91/139, 1990.

; BACIGALUPO, Silvina. Derecho penal económico. Madrid: Centro de Estúdios Ramón Areces, 2001.

FERRARI, Eduardo Reale. Termos de Compromisso de Cessação (TCC) e seus reflexos no crime de cartel. Boletim IBCCRIM, São Paulo: IBCCrim, n 190, ano 16, pp. 9/10, set., 2008 .

Legislação penal antitruste: direito penal econômico e sua acepção constitucional. In: FARIA COSTA, José Francisco de; SILVA, Marco Antonio Marques da. (coords.). Direito penal especial, processo penal e direitos fundamentais. São Paulo: Quartier Latin, pp. 579/625, 2006.

FERRAZ JÚNIOR, Tércio Sampaio. A economia e o controle do estado. In: O Estado de S. Paulo, edição de 04.06.1989. 
Conceito jurídico de oligopólio e a legislação sobre o abuso de poder econômico. Cadernos de Direito Tributário e Finanças Públicas. São Paulo, vol. 3, nº 9, pp. 192/201, out./dez., 1994.

. Indício e prova de cartel. In: Estudos - Documentos. $\mathrm{N}^{\mathrm{o}} 24$, Reunião do Conselho Superior de Assuntos Jurídicos e Legislativos (Conjur), realizada em 27 de março de 2003, na sede da Fiesp/Ciesp.

FERREIRA, Aurélio Buarque de Holanda. Dicionário Aurélio da língua portuguesa. 1. ed., Rio de Janeiro: Nova Fronteira, 1988.

FONSECA, João Bosco Leopoldino da. Lei de proteção da concorrência: comentários à legislação antitruste. Rio de Janeiro: Forense, 2007.

Direito econômico. Rio de Janeiro: Forense, 2003.

FONSECA, Pedro Henrique Carneiro. O Ministério Público e o acordo de leniência. Boletim do Instituto de Ciências Penais, nº 83, ano VI, pp. 6/10, nov., 2007.

FORGIONI, Paula A. Os fundamentos do antitruste. 2. ed., rev. e atual., São Paulo: Revista dos Tribunais, 1998.

FRAGOSO, Heleno Cláudio. Lições de direito penal. Parte geral, 16. ed., Rio de Janeiro: Forense, 2003.

FRANÇA. AUTORITÈ DE LA CONCURRENCE. Procedural notice relating to the French Leniency Programme issued on March 2nd, 2009. Disponível em <http://www.autoritedelaconcurrence.fr/doc/cpro_clemence_uk_2_mars_2009.pdf >. Acesso em 5 de junho de 2011.

FRANCESCHINI, José Inácio Gonzaga. Direito da concorrência. São Paulo: Singular, 2000.

Disciplina jurídica do abuso do poder econômico. Revista dos Tribunais. São Paulo: Revista dos Tribunais, ${ }^{\circ}$ 640, pp. 257/262, fev., 1989. 
Introdução ao direito da concorrência. São Paulo: Malheiros, 1996.

Roteiro do processo penal-econômico na legislação de concorrência. Revista do Instituto Brasileiro de Estudos das Relações de Concorrência e de Consumo. Vol. 5, nº 10, 1998.

; FRANCESCHINI, José Luiz Vicente de Azevedo. Poder econômico: exercício e abuso - Direito Antitruste brasileiro. São Paulo: Revista dos Tribunais, 1985.

FRANCO, Alberto Silva. Crimes hediondos. 6. ed., rev. atual. e ampl., São Paulo: Revista dos Tribunais, 2005.

FREDERICO MARQUES, José. Elementos de direito processual penal. Vol. I, 2. ed., atual., Campinas: Millennium, 2003.

Elementos de direito processual penal. Vol. III, 2. ed., atual., Campinas: Millennium, 2003.

. Estudos de direito processual penal. 2. ed., Campinas: Millennium, 2001.

Instituições de processo civil. Vol. I, Rio de Janeiro: Forense, 1958.

GABAN, Eduardo Molan. Acordos de leniência no Brasil (Lei n. 8.884/94). Disponível em <http://www.sampaioferraz.com.br/images/acordos_leniencia.pdf>. Acesso em 3 de março de 2010.

Assimetria de informação e barreiras à livre concorrência. Revista do IBRAC. São Paulo: IBRAC, vol. 11, nº 2, pp. 83/106, 2004.

; DOMINGUES, Juliana Oliveira. Direito antitruste: o combate a cartéis. 2. ed., São Paulo: Saraiva, 2009.

GALLINO, Rafael Miranda. Delitos contra el orden económico. Buenos Aires: Pannedille, 1970. 
GAMEIRO, João Augusto Prado da Silveira. O tratamento penal do cartel de empresas no ordenamento jurídico brasileiro. Dissertação de Mestrado. São Paulo: Faculdade de Direito, Universidade de São Paulo, 2007.

GARCIA, Roberto Soares. Delação premiada: ética e moral, às favas. Boletim IBCCRIM, $\mathrm{n}^{\mathrm{o}}$ 159, fev./2006. Disponível em <http://www.ibccrim.org.br/site/boletim/_ imprime. php?id=3158\&idBol=188>. Acesso em 12 de abril de 2008.

GEMAQUE, Silvio César Arouck. Chamada do co-réu. Revista TRF - $3^{a}$ Região. Vol. 61, p. 47, set./out., 2003.

GOMES, Mariângela Gama de Magalhães. O princípio da proporcionalidade no direito penal. São Paulo: Revista dos Tribunais, 2003.

GOMES, Orlando e VARELA, Antunes. Direito econômico. São Paulo: Saraiva, 1977.

GRAU, Eros Roberto. A ordem econômica na Constituição de 1988: interpretação e crítica. 14. ed., rev. e atual., São Paulo: Malheiros, 2000.

Elementos de direito econômico. São Paulo: Revista dos Tribunais, 1981.

GRÉCIA. HELLENIC COMPETITION COMMISSION. Decision no 299/v/2006 of the Plenary of the Hellenic Competition Commission. Disponível em <http://www.epant.gr/img/x2/news/news151_1_1224579290.pdf>. Acesso em 5 de junho de 2011.

GRECO FILHO, Vicente. Dos crimes da lei de licitações. São Paulo: Saraiva, 1994.

GREENE, Theodore Meyer. Liberalismo: teoria e prática. São Paulo: Ibrasa, 1983.

GRIFFIN, James M. A summary overview of the antitrust division's criminal enforcement program. The modern leniency program after ten years. Disponível em <http://www.usdoj.gov/atr/public/speeches/201477.htm>. Acesso em 20 de maio de 2008. 
GRINBERG, Mauro. Processos atacam prática de cartel. Disponível em <http://www.araujopolicastro.com.br/download.asp?file=Cade_e_a_Regra_da_Razao.doc> Acesso em 17 de junho de 2008.

O CADE e a regra da razão. Disponível em <http://www.araujopolicastro. com.br/download.asp?file=Cade_e_a_Regra_da_Razao.doc $>$. Acesso em 5 de fevereiro de 2008.

HAMMOND, Scott D. Cornerstones of an effective leniency program. ICN Workshop on Leniency Programs. Sidney, 23 de nov./2004. Disponível em <http://usdoj.gov/atr/public/speeches/206611.htm>. Acesso em 19 de maio de 2008.

Detecting and deterring cartel activity through an effective leniency program. International Workshop on Cartels. Disponível em <http://www.usdoj. gov/atr /public/ speeches/9928.pdf>. Acesso em 19 de maio de 2008.

Fighting cartels - why and how? Lessons common to deterring criminal activity. Set./2000. Disponível em <www.usdoj.gov/atr/public/speechs>. Acesso em 15 de setembro de 2008 .

HARRINGTON JR.; Joseph E.; CHEN, Joe. The impact of the corporate leniency program on cartel formation and the cartel price path. Political Economy of Antitrust. 2005. Disponível em <http://www.econ.jhu.edu/People/Harrington/leniency4-05.pdf>. Acesso em 17 de junho de 2008.

HOLMES, Simon; GIRARDET, Philipp. Chapter 40: United Kingdom. In: The International Comparative Legal Guide to: Cartels and Leniency 2011: a practical cross-border insight into cartels and leniency. Londres: Global Legal Group. Disponível em <http://www.iclg.co.uk/khadmin/Publications/pdf/4130.pdf $>$. Acesso em 5 de junho de 2011.

HOVENKAMP, Herbert. Federal antitrust policy - the law of competition and its practice. St. Paul: Hornbook series, West Publishing CO., 1999. 
HUNGRIA, Nelson. Dos crimes contra a economia popular. Rio de Janeiro: Livraria Jacinto, 1939.

INTERNATIONAL COMPETITION NETWORK. Drafting and implementing an effective leniency program. P. 8 (2006). Disponível em <http://www.international competitionnetwork.org/capetown2006/FINALFormattedChapter2-modres.pdf〉. Acesso em 5 de fevereiro de 2008.

JAKOBS, Günther. Fundamentos do direito penal. Tradução de André Luís Callegari. São Paulo: Revista dos Tribunais, 2003.

LEVY, Nicholas e O'DONOGHUE, Robert. The EU leniency programme comes of age. World Competition, 27 (1), pp. 75/99, 2004.

LIMA, Heitor Ferreira. História político-econômica e industrial do Brasil. São Paulo: Companhia Editora Nacional, 1976.

LOBÃO, Carla. Compromisso de cessação de prática: uma abordagem crítica sobre o instituto. Revista do IBRAC. São Paulo: IBRAC, vol. 8, nº 8, pp. 87/98, 2001.

LYRA, Roberto. Criminalidade econômico-financeira. Rio de Janeiro: Forense, 1978.

MAIA, Rodolfo Tigre. Tutela penal da ordem econômica: o crime de formação de cartel. São Paulo: Malheiros, 2008.

MANTECCA, Pascoal. Crimes contra a economia popular e sua repressão. São Paulo: Saraiva, 1985.

MANZINI, Vicenzo. Trattato di diritto penale. s. 1.: UTET. v. 3, 1921.

MARCÃO, Renato. Delação premiada. Revista Síntese de Direito Penal e Processual Penal. Porto Alegre: Síntese, ano VI, nº 35, pp. 160/163, dez./jan., 2006. 
MARTINEZ, Ana Paula. A proteção dos consumidores pelas normas concorrenciais. Revista de Direito do Consumidor. № 52, pp. 7/36, São Paulo: Revista dos Tribunais, 2004.

MATA Y MARTÍN, Ricardo M. Bienes jurídicos intermédios y delitos de peligro. Granada: Comares, 1997.

MAZZUCATO, Paolo Zupo. Acordo de leniência - a política econômica de combate a cartéis. Dissertação de Mestrado em Direito Econômico. Belo Horizonte: Faculdade de Direito, Universidade Federal de Minas Gerais, 2004.

Acordo de leniência: questões controversas sobre o artigo 35-C da Lei Antitruste. Revista do IBRAC. São Paulo: IBRAC, nº 17, pp. 169/209, jan./jun., 2010.

MITTERMAYER, Carl Joseph Anton. Prova em matéria criminal. Rio de Janeiro: Jacinto Ribeiro dos Santos, 1917.

Tratado das provas em direito criminal. Rio de Janeiro: Jacinto Ribeiro dos Santos, 1909.

MONREAL, Eduardo Novoa. Reflexões para a determinação do delito econômico. Revista de Direito Penal e Criminologia. Rio de Janeiro: Forense, $\mathrm{n}^{\mathbf{o}}$ 33, pp. 90/121, jan./jun, 1982.

MORAES, Bernardo Bissoto Queiroz de. Monopólios e acordos de não concorrência na antiguidade. Revista de Direito Econômico. Brasília: CADE, n 32, pp. 9/32, jul./dez., 2001.

MOREIRA, Eduardo Athayde de Souza; PEÑALOZA, Rodrigo. Programas de leniência, corrupção e o papel da Corregedoria da autoridade antitruste. Brasília: Associação Nacional dos Centros de Pós Graduação em Economia, Universidade de Brasília, 2004. Disponível em <http://econpapers.repec.org/paper/anpen2004/091.htm>. Acesso em 10 de outubro de 2008.

MOREIRA, Vital. Economia e constituição. Coimbra: Coimbra Editora, 1979. 
MOURA, Fabíola; BELTRAME, Priscila Akemi. Diretrizes para elaboração e implementação de política de defesa da concorrência. São Paulo: Singular, 2003.

MUNHOZ, Carolina Pancotto Bohrer. Direito, livre concorrência e desenvolvimento. São Paulo: Lex Editora, 2006.

NALINI, José Renato. Ética geral e profissional. São Paulo: Revista dos Tribunais, 2004.

NERY, Daniel Christianini. A confissão na apuração de cartéis e os benefícios concedidos pela autoridade antitruste. Disponível em <http://www.revistaautor. com/index.php?option=com_content\&task=view\&id=241\&Itemid=38>. Acesso em 10 de fevereiro de 2010.

NUSDEO, Ana Maria de Oliveira. Defesa da concorrência e globalização econômica - o controle da concentração de empresa. São Paulo: Malheiros, 2002.

NUSDEO, Fabio. Curso de economia: introdução ao Direito Econômico. 6. ed., rev. e atual., São Paulo: Revista dos Tribunais, 2000.

OCDE. Lei e política de concorrência no Brasil: uma revisão pelos pares. Disponível em <http://www.mj.gov.br/sde/dpde/documentos/BrasilPort.pdf $>$. Acesso em 15 de janeiro de 2008.

Lei e política de concorrência no Brasil: uma revisão pelos pares - 2010. Disponível em <http://www.oecd.org/dataoecd/4/41/45154401.pdf>. Acesso em 28 de agosto de 2010.

Using leniency to fight hard core cartels. Overview. 2002. Disponível em <http://www.oecd.org/dataoecd/11/31/1935123.pdf>. Acesso em 25 de outubro de 2009.

1998 OECD recommendation of the Council concerning effective action against Hard Core Cartels (adotada pelo Conselho da OCDE em sua sessão de 25 de março de 1998 [C/M (98)7/PROV]. Disponível em <http://www.oecd.org/dataoecd 139/4/2350130.pdf>. Acesso em 13 de outubro de 2009. 
OLIVEIRA, Eugênio Pacelli de. Curso de processo penal. 4. ed., rev. e ampl., Belo Horizonte: Del Rey, 2005.

OLIVEIRA, Gesner; RODAS, João Grandino. Direito e economia da concorrência. Rio de Janeiro: Renovar, 2004.

A cenoura e o porrete contra os cartéis. Folha de S. Paulo. Seção Opinião, 15.11.2003.

OLIVEIRA JÚNIOR, Gonçalo Farias de. Ordem econômica e direito penal antitruste. 2. ed., Curitiba: Juruá, 2009.

OLIVEIRA LIMA, José Luis; DALL'ACQUA, Rodrigo. Ordem econômica. A inconstitucionalidade do acordo de leniência. Disponível em <http://conjur.estadao. com.br/static/text/56202?display_mode=print>. Acesso em 06 de maio de 2008.

; __ Os cartéis em licitação e o acordo de leniência. Disponível em <http://www.administradores.com.br/artigos/os_carteis_em_licitacao_e_o_acordo_de_leni encia/33757/>. Acesso em 2 de outubro de 2010.

OSÓRIO, Fábio Medina. Direito administrativo sancionador. São Paulo: Revista dos Tribunais, 2005.

PEARSON, Edward S. Law for European Business Studies. Great Britain, 1994, p. 310. Apud SAYEG, Ricardo Hasson. A proteção do consumidor contra o monopólio. Revista do IBRAC. São Paulo: IBRAC, nº 05, v. 03, pp. 103/113, mai., 1996.

PATRÍCIO, J. Simões. Curso de direito econômico. 1981. Apud FONSECA, João Bosco Leopoldino da. Direito econômico. Rio de Janeiro: Forense, 2003.

PIMENTEL, Manoel Pedro. Direito penal econômico. São Paulo: Revista dos Tribunais, 1973.

PINTO, Aníbal. Curso de economia: elementos de teoria econômica. 8. ed., Rio de Janeiro: Unilivros, 1980. 
POPP, Carlyle; ABDALA, Edson Vieira. Comentários à nova lei antitruste. Curitiba: Juruá, 1997.

PRADO, Luiz Regis. Bem jurídico-penal e constituição. 3. ed., São Paulo: Revista dos Tribunais, 2003.

Direito penal econômico: ordem econômica, relações de consumo, sistema financeiro, ordem tributária, sistema previdenciário. 2. ed., rev., atual. e amp., São Paulo: Revista dos Tribunais, 2004.

REALE, Miguel. Aplicações da Constituição de 1988. Rio de Janeiro: Forense, 1991.

Filosofia do direito. São Paulo: Saraiva, 2002.

Lições preliminares de direito. São Paulo: Saraiva, 2002.

REALE JÚNIOR, Miguel. Cartel e quadrilha ou bando: bis in idem. Revista de Ciências Penais. São Paulo: Revista dos Tribunais, nº 05, pp. 131/143, 2006.

Despenalização no direito penal econômico: uma terceira via entre o crime e a infração administrativa? Revista Brasileira de Ciências Criminais. São Paulo: IBCCRIM, no 28 , v. 7, pp. 116-129, out./dez., 1999.

REINO UNIDO. OFFICE OF FAIR TRADING. Leniency in cartel cases. A guide to the leniency programme for cartels. Disponível em <http://www.oft.gov.uk/shared_oft /business_leaflets/ca98_mini_guides/oft436.pdf>. Acesso em 5 de junho de 2011.

The cartel offence: guidance on the issue of no-action letters for individuals. Disponível em <http://www.oft.gov.uk/shared_oft/business_leaflets/enterprise_act/oft513 .pdf>. Acesso em 5 de junho de 2011.

RIBEIRO, Amadeu; NOVIS, Maria Eugênia. Programa brasileiro de leniência: evolução, efetividade e possíveis aperfeiçoamentos. Revista do IBRAC. São Paulo: IBRAC, $n^{\text {o }} 17$, pp. 147/168, jan./jun., 2010. 
RIBEIRO, Roseli. Para especialistas, justiça deve participar de acordos de leniência do CADE. Disponível em <http://ultimainstancia.uol.com.br/imprime_noticia.php?idNoticia $=39593>$. Acesso em 10 de fevereiro de 2009 .

RIOS, Rodrigo Sánchez. Reflexões sobre o delito econômico e sua delimitação. Revista dos Tribunais. São Paulo: Revista dos Tribunais, nº 775, p. 442, mai., 2000.

ROBALDO, José Carlos de Oliveira; VIEIRA, Vanderson Roberto. A sociedade de risco e a dogmática penal. Disponível em <www.ibccrim.org.br>. Acesso em 16 de junho de 2006.

RODAS, João Grandino. Acordos de leniência em direito concorrencial: práticas e recomendações. Revista dos Tribunais. São Paulo: Revista dos Tribunais, nº 862, v. 96, pp. 22/33, ago., 2007.

_. Dawn raids busca e apreensão no âmbito antitruste - práticas e recomendações. Revista dos Tribunais. São Paulo: Revista dos Tribunais, v. 851, pp. 417/431, set., 2006.

RODRIGUES, Geisa de Assis. Breves considerações sobre o compromisso de cessação de prática. In: ROCHA, João Carlos de Carvalho et alli (coord.) Lei antitruste: 10 anos de combate ao abuso do poder econômico. Belo Horizonte: Del Rey, 2005.

ROSENBERG, Bárbara. Investigações de cartel e acordos. Revista Jurídica Consulex. Brasília: Consulex, ano XII, nº 270, p. 57, abr., 2008.

ROSO, Jayme Vita. Novos apontamentos à lei antitruste brasileira. São Paulo: LTr, 1998.

ROSSETTO, Enio Luiz. A confissão no processo penal. São Paulo: Atlas, 1999.

RUSSELL, Robert e PACIOCCO, Mark. Chapter 9. Canada. In: The international comparative legal guide to: cartels and leniency 2011: a practical cross-broder insight into cartels and leniency. Londres: Global Legal Group. Disponível em 
<http://www.iclg.co.uk/khadmin/Publications/pdf/4098.pdf>. Acesso em 10 de junho de 2011.

SARNEY, José. Bordalesa e delação premiada. Folha de S. Paulo. 26 de agosto de 2005. Disponível em <http://clipping.planejamento.gov.br/Notícias.asp?NOTCod=216378>. Acesso em $1^{\circ}$ de março de 2010.

SALOMÃO FILHO, Calixto. Direito concorrencial - as estruturas. 3. ed., São Paulo: Malheiros, 2002.

Direito concorrencial - as condutas. 1. ed., São Paulo: Malheiros, 2003.

Regulação e concorrência (estudos e pareceres). São Paulo: Malheiros, 2002.

SANDRONI, Paulo (org. e superv.). Novíssimo dicionário de economia. São Paulo: Best Seller, 2003.

SANTANA VEGA, Dulce Maria. La protección penal de los bienes jurídicos colectivos. Madrid: Dykinson, 2000.

SANTOS, André Maciel Vargas dos. O acordo de leniência e seus reflexos no direito penal. Disponível em <http://jus2.uol.com.br/doutrina/texto.asp?id=10270>. Acesso em 6 de maio de 2008.

SANTOS, Gérson Pereira dos. Direito penal econômico. São Paulo: Saraiva, 1981.

SCOTT, Sheridan. Palestra proferida para a FIESP em 12 de maio de 2008. Disponível em <www.internationalcompetitionnetwork.org/media/library/News/Sheridan_Scott_ Portuguese_spees.pdf >. Acesso em $1^{\text {o }}$ de janeiro de 2009.

SHIEBER, Benjamin M. Abusos do poder econômico. São Paulo: Revista dos Tribunais, 1966.

SICA, Leonardo. Tutela penal da ordem econômica no direito brasileiro: comparação entre as Leis n. ${ }^{\circ}$ s 8.137/90 e 8.884/94. In: PEREIRA, Flávia Rahal Bresser; VILARDI, Celso; 
DIAS NETO, Theodomiro (coords.). Análise contemporânea. Série GVLAW Direito Penal Econômico. São Paulo: Saraiva, pp. 145/185, 2009.

SILVA, José Afonso da. Curso de direito constitucional positivo. 23. ed., rev e atual.,São Paulo: Malheiros, 2003.

SILVA, Américo Luís Martins da. A ordem constitucional econômica. Rio de Janeiro: Forense, 2003.

SILVA, Vladimir Spíndola. O instituto da leniência no direito antitruste norteamericano. Revista do IBRAC. São Paulo: IBRAC, $n^{\circ}$ 1, v. 9, pp. 323/345, 2002. Disponível em <http://www.justice.gov/atr/public/guidelines/0091.htm>. Acesso em 2 de junho de 2011.

SILVEIRA, Renato de Mello Jorge. Direito penal supra-individual: interesses difusos. São Paulo: Revista dos Tribunais, 2003.

A construção do bem jurídico espiritualizado e suas críticas fundamentais. Boletim do IBCCrim. São Paulo: IBCCRIM, n 122, jan., 2003.

SMITH, Adam. A riqueza das nações. São Paulo: Martins Fontes, 2003.

SOARES, Rafael Junior. Da impossibilidade do uso do acordo de leniência como forma de impedir o oferecimento de denúncia pelo Ministério Público. Boletim IBCCrim. São Paulo: IBCCrim, $\mathrm{n}^{\mathrm{o}} 215$, out., 2010.

SOBRAL, Ibrahim Acácio Espírito. O acordo de leniência: avanço ou precipitação? Revista do IBRAC. São Paulo: IBRAC, nº 2, v. 8, pp. 131/146, 2001.

SOUZA, Nali de Jesus. Curso de economia. São Paulo: Atlas. 2000.

SOUZA, Washington Peluso Albino de. Primeiras linhas de direito econômico. 6. ed., São Paulo: LTr. 2005.

Direito econômico. São Paulo: Saraiva. 1980. 
SPRATLING, Gary G. Making companies an offer they shouldn't refuse. Disponível em <http://www.usdoj.gov/atr/public/speeches/2247.htm>. Acesso em 10 de maio de 2008.

Cornerstones of an effective leniency program (2004). Disponível em <http://www.usdoj.gov/atr/public/speeches/206611.htm>. Apud RODAS, João Grandino. Acordos de leniência em direito concorrencial: práticas e recomendações. Revista dos Tribunais. São Paulo: Revista dos Tribunais, nº 862, v. 96, pp. 22/33, ago., 2007.

STIGLITZ, Joseph E.; WAKSH, Carl E. Introdução à microeconomia. Rio de Janeiro: Campus, 2003.

STOCO, Rui. Crimes contra a ordem tributária. In: FRANCO, Alberto Silva et alli. Leis penais e sua interpretação jurisprudencial. Vol. 1, 7. ed., São Paulo: Revista dos Tribunais, 1945.

TORNAGHI, Helio. Instituições de processo penal. Vol. 4. 2. ed., Rio de Janeiro: Forense, 1978.

VALÉRIO, Marco Aurélio Gumieri. Acordo de leniência: a delação premiada como instrumento de combate ao cartel. Revista de Direito Mercantil, Industrial, Econômico e Financeiro. São Paulo: Malheiros, nº 143, vol. 45, pp. 188/201, jul./set., 2006.

VAZ, Isabel. Direito econômico da concorrência. Rio de Janeiro: Forense, 1993.

VICENTINI, Pedro C. E. A confissão de culpa nos Termos de Compromisso de Cessação: requisito essencial ou prescindível, face ao programa de leniência? Revista do IBRAC. São Paulo: IBRAC, nº 17, pp. 252-274, jan./jun., 2010.

VIEIRA, Caroline Sanselme. O primeiro acordo de leniência firmado no Brasil. Revista de Direito Internacional Econômico. Porto Alegre: Síntese, ano 03, no 11, pp. 91/98, abr./mai./jun., 2005.

VILELA, Juliana Girardelli. Aspectos relevantes do programa de leniência. Revista de Direito Mercantil, Industrial, Econômico e Financeiro. São Paulo: Malheiros, $\mathrm{n}^{\circ} 139$, v. 44, pp. 202/215, jul./set., 2005. 